\title{
PENGELOLAAN JALUR HIJAU JALAN DI KELURAHAN BARANANGSIANG OLEH DINAS KEBERSIHAN DAN PERTAMANAN, KOTA BOGOR
}

\section{PUTRI MARIAM ANINDITA ERLINE}

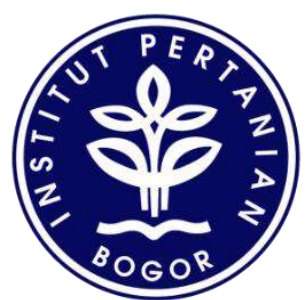

\author{
DEPARTEMEN ARSITEKTUR LANSKAP \\ FAKULTAS PERTANIAN \\ INSTITUT PERTANIAN BOGOR \\ BOGOR \\ 2015
}




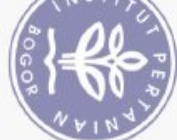

들 믈

을 뭉영

을을 하

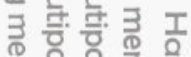

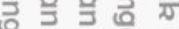

둘 흘등 웅

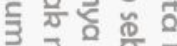

을

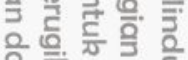

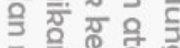

3 중

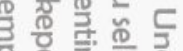

일

흥 志웓

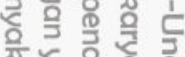

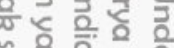

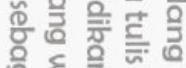

응. ํㅡㅇ

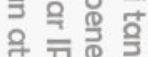

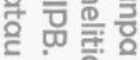

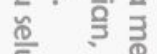

독 올

을 를

ไุำ

ट

들 느응

을 글

일

उ

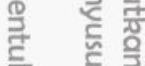

응 일

을 흉 휴

章

항

촐. 를

鬲

紫

임

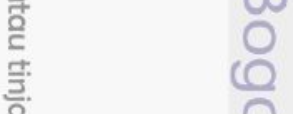

은 은

훌

1

응

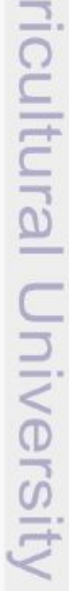




\section{PERYATAAN MENGENAI SKRIPSI DAN SUMBER INFORMASI SERTA PELIMPAHAN HAK CIPTA}

Dengan ini saya menyatakan bahwa skripsi berjudul "Pengelolaan Jalur Hijau Jalan di Kelurahan Baranangsiang, Kota Bogor" adalah benar karya saya dengan arahan dari dosen pembimbing dan belum diajukan dalam bentuk apa pun kepada perguruan tinggi mana pun. Sumber informasi baik yang berasal atau dikutip dari karya yang diterbitkan maupun yang tidak diterbitkan dari penulis lain telah disebutkan dalam teks dan dicantumkan dalam Daftar Pustaka di bagian akhir skripsi ini.

Dengan ini saya melimpahkan hak cipta dari karya tulis saya kepada thstitut Pertanian Bogor.

Bogor, Juni 2015

Putri Mariam Anindita Erline

NRP A44100042 


\section{ABSTRAK}

PUTRI MARIAM ANINDITA ERLINE. Pengelolaan Jalur Hijau Jalan di Kelurahan Baranangsiang oleh Dinas Kebersihan dan Partamanan, Kota Bogor. Dibimbing oleh WAHJU QAMARA MUGNISJAH.

Pembangunan Kota Bogor khususnya di Kelurahan Baranangsiang menyebabkan perubahan keadaan lingkungan. Pembangunan yang tidak seimbang dapat mengurangi kualitas lingkungan. Ruang terbuka hijau (RTH) adalah salah satu solusi dalam meningkatkan kualitas kota. Jalur Gijau merupakan RTH utama dalam kota dan vegetasi jalur hijau Бेerkontribusi terhadap kualitas udara dengan menyaring partikel. Oleh sebab itu, pengelolaan jalur hijau di Kelurahan Baranangsiang sangat penting. Tujuan dari penelitian ini adalah untuk menginventarisasi, mengevaluasi, serta menyusun strategi dan rencana pengelolaan jalur hijau jălan di Kelurahan Baranangsiang. Tahapan penelian terdiri dari tahap persiapan, inventarisasi tapak, pengolahan data, analisis, dan sintesis. Data đianalisis dengan menggunakan deskriptif dan analisis SWOT. Terdapat Enam alternatif strategi yang dihasilkan untuk pengelolaan lanskap di jalur Gijau Kelurahan Baranangsiang.

7

Kata kunci: jalur hijau jalan, ruang terbuka hijau, pengelolaan, alternatif strategi, Kelurahan Baranangsiang

\section{ABSTRACT}

PUTRI MARIAM ANINDITA ERLINE. Management of Greenway in Baranangsiang Village by Cleanliness and Landscaping Services. Bogor Municipal. Supervised by WAHJU QAMARA MUGNISJAH.

The development of Bogor City especially in Baranangsiang Village makes environmental changes. Unbalanced development can reduce the quality of environment. Green open space is one of the solution which can increase the quality of city. Greenway is major green open space in the city and greenway's vegetation contribute to air quality by filtering out particulate matter. Therefore, the management of greenway in Baranangsiang Village is very important. Aims of this research were to (inventory, evaluate, and provide management strategy and plan of greenway in Baranangsiang Village. Stages of research were preparation, site inventory, analysis, and synthesis. The data were analyzed by using descriptive and SWOT analysis. There are six alternative strategies for landscape management of Baranangsiang Village's greenway.

\section{Keywords:}

greenway, green open space, management, alternative strategy, Baranangsiang Village 


\section{Hak Cipta Dilindungi Undang-undang}

Dilarang mengutip sebagian atau seluruh karya tulis ini tanpa mencantumkan atau menyebutkan sumbernya. Pengutipan hanya untuk kepentingan pendidikan, penelitian, penulisan karya ilmiah, penyusunan laporan, penulisan kritik, atau finjauan suatu masalah, dan pengutipan tersebut tidak merugikan kepentingan IPB.

Đilarang mengumumkan dan memperbanyak sebagian atau seluruh karya tulis ini ¿dalam bentuk apa pun tanpa izin IPB. 


\title{
PENGELOLAAN JALUR HIJAU JALAN \\ DI KELURAHAN BARANANGSIANG OLEH DINAS KEBERSIHAN DAN PERTAMANAN, KOTA BOGOR
}

\section{PUTRI MARIAM ANINDITA ERLINE}

\author{
Skripsi \\ sebagai salah satu syarat untuk memperoleh gelar \\ Sarjana Arsitektur Lanskap \\ pada \\ Departemen Arsitektur Lanskap
}

\author{
DEPARTEMEN ARSITEKTUR LANSKAP \\ FAKULTAS PERTANIAN \\ INSTITUT PERTANIAN BOGOR \\ BOGOR \\ 2015
}


Judul Skripsi : Pengelolaan Jalur Hijau Jalan di Kelurahan Baranangsiang oleh Dinas Kebersihan dan Pertamanan, Kota Bogor

Nama : Putri Mariam Anindita Erline

NIM

: A44100042

Disetujui oleh

Prof. Dr. Ir. Wahju Qamara Mugnisjah, M. Agr.

Pembimbing Skripsi

Diketahui oleh

Dr. Ir. Bambang Sulistyantara, M. Agr.

Ketua Departemen

anggal Lulus: 


\section{PRAKATA}

Puji dan syukur penulis panjatkan kepada Allah Swt. atas rahmat dan hidayah-Nya sehingga skripsi berjudul "Pengelolaan Jalur Hijau Jalan di Kelurahan Baranangsiang oleh Dinas Kebersihan dan Pertamanan, Kota Bogor" berhasil diselesaikan.

Banyak pihak yang telah membantu penulis dalam tahap persiapan hingga akhir penyusunan. Oleh karena itu, dalam kesempatan ini penulis ingin menyampaikan terima kasih kepada Prof. Dr. Ir. Wahju Qamara Mugnisjah, M. Agr. selaku pembimbing skripsi, kepada Wida Wardati Khumairo yang telah membantu proses survei lapang, kepada Ibu Devi Eibrianti Juvita Permata, SP, MPP, MT dan jajaran dari Dinas Kebersihan dan Pertamanan, Kota Bogor, yang telah membantu dalam proses pengumpulan data.

Penulis berharap semoga hasil penelitian yang disajikan dalam bentuk $\overline{\bar{s}}$ kripsi ini dapat bermanfaat bagi semua pihak.

Bogor, Juni 2015

Putri Mariam Anindita Erline 


\section{DAFTAR ISI}

DAFTAR TABEL

DAFTAR GAMBAR

vi

DAFTAR LAMPIRAN vi

PENDAHULUAN 1

Latar Belakang 1

Tujuan 1

Manfaat 1

Kerangka Pikir 2

TINJAUAN PUSTAKA

Lanskap Jalan

Ruang Terbuka Hijau

Jalur Hijau Jalan

Fungsi Tanaman dalam Lanskap

Pengelolaan Lanskap

METODOLOGI 8

$\begin{array}{ll}\text { Lokasi dan Waktu Pelaksanaan } & 8\end{array}$

$\begin{array}{lr}\text { Bahan dan Alat } & 8\end{array}$

$\begin{array}{lr}\text { Batasan Penelitian } & 9\end{array}$

$\begin{array}{ll}\text { Metode Penelitian } & 9\end{array}$

Tahapan Penelitian 11

$\begin{array}{ll}\text { HASIL DAN PEMBAHASAN } & 14\end{array}$

$\begin{array}{ll}\text { Inventarisasi } & 14\end{array}$

Aspek Fisik dan Biofisik 14

Aspek Sosial 34

Aspek Kegiatan Pengelolaan 34

Analisis Deskriptif 40 
$\begin{array}{ll}\text { Analisis Aspek Fisik dan Biofisik } & 40\end{array}$

Analisis Preferensi Pengguna 63

$\begin{array}{ll}\text { Analisis Kegiatan Pengelolaan } & 73\end{array}$

$\begin{array}{ll}\text { Analisis SWOT } & 78\end{array}$

$\begin{array}{ll}\text { Faktor Strategis Internal } & 78\end{array}$

$\begin{array}{ll}\text { Faktor Strategis Eksternal } & 79\end{array}$

$\begin{array}{ll}\text { Alternatif Strategi } & 84\end{array}$

Meningkatnya Hubungan Kemitraan dengan Membuka Peluang 84

Kerja Sama Seluas-luasnya dengan Pihak Eksternal

Meningkatkan Kebersihan dan Keindahan dari jalur hijau $\quad 84$

$\begin{array}{ll}\text { Menyusun Rencana Pengelolaan } & 84\end{array}$

Meningkatkan Pengawasan dan Memberikan Sanksi kepada $\quad 85$

Pihak yang Merusak Jalur Hijau Jalan

Mengadakan Pelatihan untuk Para Pekerja 85

Meningkatkan Kuantitas dan Kualitas Alat dan Bahan $\quad 85$

Pemeliharaan

$\begin{array}{ll}\text { Rencana Pengelolaan } & 85\end{array}$

$\begin{array}{ll}\text { Struktur Organisasi } & 55\end{array}$

$\begin{array}{ll}\text { Jadwal Kegiatan } & 86\end{array}$

Tenaga Kerja $\quad 86$

$\begin{array}{ll}\text { Alat dan Bahan } & 96\end{array}$

$\begin{array}{ll}\text { Rencana Anggaran Biaya } & 96\end{array}$

SIMPULAN DAN SARAN 98

$\begin{array}{ll}\text { Simpulan } & 98\end{array}$

$\begin{array}{ll}\text { Saran } & 99\end{array}$

ĐAFTAR PUSTAKA 100

IAMPIRAN 103

RIWAYAT HIDUP 113 


\section{DAFTAR TABEL}

1. Data yang diperlukan dalam penelitian

2. Contoh penilaian bobot strategis faktor internal 12

3. Contoh Matriks Internal Factor Evaluation (IFE) 12

4. Matriks Internal-Eksternal 13

5. Contoh Matriks SWOT 13

6. Lokasi jalur hijau jalan di Kelurahan Baranangsiang 14

7. Jenis jaringan jalan 15

8. Vegetasi jalur hijau jalan di Jalan Raya Pajajaran Segmen I 16

9. Vegetasi jalur hijau jalan di Jalan Raya Pajajaran Segmen II 19

10. Vegetasi jalur hijau jalan di Jalan Raya Pajajaran Segmen III 22

f1. Vegetasi di tepi Jalan Otto Iskandardianta 25

\$2. Vegetasi di median Tol Jagorawi 26

量3. Vegetasi jalur hijau jalan di Jalan Bina Marga 27

14. Vegetasi di tepi Jalan Padi 29

15. Vegetasi di median Jalan Pakuan 30

¥6. Site structure di Jalan Raya Pajajaran Segmen I 31

17. Site structure di Jalan Raya Pajajaran Segmen II 32

18. Site structure di Jalan Raya Pajajaran Segmen III 32

19. Site structure di Jalan Otto Iskandardinata 33

20. Site structure di Tol Jagorawi 33

21. Site structure di Jalan Bina Marga 33

22. Site structure di Jalan Padi 33

23. Site structure di Jalan Pakuan 33

24. Frekuensi kegiatan pemeliharaan 38

25. Peralatan pemeliharaan 39

26. Pihak pengelola site structure $\quad 44$

27. Analisis-sintesis site structure di Jalan Raya Pajajaran Segmen I 44

28. Analisis-sintesis site structure di Jalan Raya Pajajaran Segmen II 46

29. Analisis-sintesis site structure di Jalan Raya Pajajaran Segmen III 46

30. Analisis-sintesis site structure di Jalan Otto Iskandardinata 49

31. Analisis-sintesis site structure di Tol Jagorawi 49

32. Analisis-sintesis site structure di Jalan Bina Marga 50

33. Analisis-sintesis site structure di Jalan Padi $\quad 50$

34. Nama dan fungsi pohon di Jalan Raya Pajajaran Segmen I 52

35. Nama dan fungsi pohon di Jalan Raya Pajajaran Segmen II 54

36. Nama dan fungsi pohon di Jalan Raya Pajajaran Segmen III 56

37. Nama dan fungsi pohon di Jalan Otto Iskandardinata 57

38. Nama dan fungsi pohon di Jalan Bina Marga 58

39. Nama dan fungsi pohon di Tol Jagorawi $\quad 59$

40. Nama dan fungsi pohon di Jalan Padi $\quad 60$

41. Nama dan fungsi pohon di Jalan Pakuan 62

42. Perbandingan frekuensi kegiatan literatur sebagai standar 77 dan lapang

43. Jumlah alat pemeliharaan selama satu tahun 78

44. Tingkat kepentingan faktor internal 80

45. Tingkat kepentingan faktor eksternal 81 
46. Penilaian bobot strategis internal 81

47. Penilaian bobot strategis eksternal 82

48. Matriks Internal Factor Evaluation (IFE) 82

49. Matriks External Factor Evaluation (EFE) 82

50. Matriks Internal-Eksternal 82

51. Matriks SWOT 83

52. Peringkat alternatif strategi $\quad 84$

53. Rekomendasi kegiatan pemeliharaan 86

54. Perhitungan HOK di Jalan Raya Pajajaran Segmen I 87

55. Perhitungan HOK di Jalan Raya Pajajaran Segmen II 88

56. Perhitungan HOK di Jalan Raya Pajajaran Segmen III 90

57. Perhitungan HOK di Jalan Otto Iskandardinata 91

58. Perhitungan HOK di Jalan Bina Marga 92

59. Perhitungan HOK di Jalan Padi 93

60. Perhitungan HOK di Jalan Pakuan 94

61. Perhitungan HOK di median Tol Jagorawi 95

62. Kebutuhan alat dan bahan pemeliharaan selama satu tahun 96

63. Anggaran biaya pemeliharaan selama satu tahun 97

64. Anggaran pengadaan alat selama satu tahun 97

65. Angggaran pengadaan bahan pemeliharaan selama satu tahun 98

\section{DAFTAR GAMBAR}

Bagan kerangka pikir jalur hijau jalan di Kelurahan Baranangsiang 2 Ilustrasi bagian-bagian jalan 3 Ilustrasi jalur hijau jalan $\quad 5$

Kegiatan pengelolaan menurut Arifin et al. (2008) 7

$\begin{array}{ll}\text { Lokasi penelitian } & 8\end{array}$

$\begin{array}{lr}\text { Segmentasi } & 9\end{array}$

Sirkulasi 15

$\begin{array}{ll}\text { Ilustrasi tipikal jalan } & 16\end{array}$

9. Struktur organisasi Dinas Kebersihan dan Pertamanan (DKP) 36

10. Struktur organisasi Bidang Pertamanan 37

11. Kegiatan penyiraman jalur hijau jalan 38

12. Pengguna sepeda di jalur kendaraan bermotor 41

13. Pedagang kaki lima di jalur pejalan kaki dan bahu jalan 42

14. Pedagang tanaman hias yang menggunakan jalur pejalan kaki 43

15. Keberadaan tanaman di jalur pejalan kaki 43

16. Planter box di median jalan 46

17. Paving yang rusak di jalur pejalan kaki 47

18. Kondisi jalur kendaraan bermotor di Jalan Otto Iskandardinata 48

19. Kondisi paving dan drainase di Jalan Bina Marga 49

20. Kondisi paving di Jalan Padi $\quad 50$

21. Keragaman vegetasi 51

22. Warna kontras di median $\quad 52$

23. Pola penanaman di vegetasi 53

24. Kondisi tanaman yang belum dipangkas $\quad 54$

25. Pengguna jalan yang beristirahat di bahu jalan 55 
26. Kondisi jalur hijau jalan di (a) tepi jalan dan (b) taman sudut 57

27. Kombinasi warna cerah dari semak dan ground cover 58

28. Kesan kontras di median Tol Jagorawi 60

29. Pohon ki hujan (Samanea saman) di Jalan Padi 61

30. Pohon bunga kupu-kupu (Bauhinia purpurea Linn.) 61

31. Jarak tanam yang rapat di median memberi kesan dinding 62

32. Preferensi pejalan kaki mengenai kelima aspek 63 di Jalan Raya Pajajaran Segmen I

33. Preferensi pejalan kaki mengenai kelima aspek 64 di Jalan Raya Pajajaran Segmen II

34. Keberadaan sampah pada tapak 65

35. Preferensi pejalan kaki mengenai kelima aspek 65 di Jalan Raya Pajajaran Segmen III

36. Preferensi pejalan kaki mengenai kelima aspek 66 di Jalan Otto Iskandardinata

37. Preferensi pejalan kaki mengenai kelima aspek 67 di Jalan Bina Marga

38. Preferensi pejalan kaki mengenai kelima aspek di Jalan Padi 68

39. Preferensi pejalan kaki mengenai kelima aspek di Jalan Pakuan 69

40. Preferensi pengguna kendaraan bermotor $\quad 70$

7 di Jalan Raya Pajajaran Segmen I

41. Preferensi pengguna kendaraan bermotor 71

3. di Jalan Raya Pajajaran Segmen II

42. Preferensi pengguna kendaraan bermotor 72

To di Jalan Raya Pajajaran Segmen III

43. Preferensi pengguna kendaraan bermotor di Tol Jagorawi 73

44. Struktur organisasi yang dianjurkan Arifin dan Arifin (2005) 74

45. Area kerja tim kored $\quad 75$

46. Kegiatan pemeliharaan dilakukan bersama-sama 76

47. Pembangunan taman Botani Square 77

48. Rekomendasi struktur organisasi 86

\section{DAFTAR LAMPIRAN}

Kondisi umum jalur hijau jalan di Kelurahan Baranangsiang

Tampak potongan jalur hijau jalan di Kelurahan Baranangsiang

Kuesioner preferensi untuk pejalan kaki

Kuesioner preferensi untuk pengguna kendaraan bermotor 


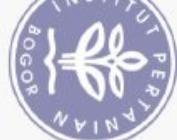

들 믈

을 뭉영

을을 하

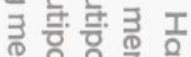

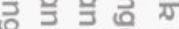

둘 흘등 웅

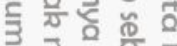

을

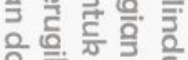

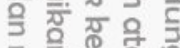

3 중

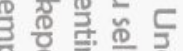

일

흥 志웓

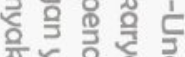

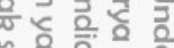

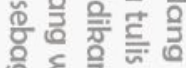

응. ํㅡㅇ

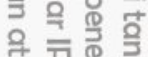

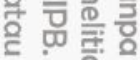

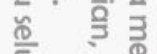

독 올

을 를

ไุำ

ट

들 느응

을 글

일

उ

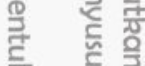

응 일

을 흉 휴

章

항

촐. 를

鬲

紫

임

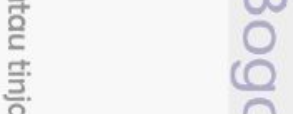

은 은

훌

1

응

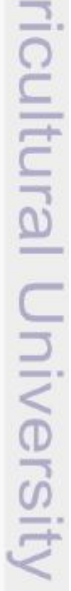




\section{PENDAHULUAN}

\section{Latar Belakang}

Kota Bogor saat ini mengalami pembangunan infrastruktur khususnya di bidang jasa. Pembangunan ini terkonsentrasi di wilayah pusat Kota Bogor, salah satunya adalah di Kelurahan Baranangsiang. Pembangunan infrastruktur bidang jasa berupa hotel yang pesat sejalan dengan posisi Kota Bogor sebagai kota jasa (Rustiadi dalam Latief 2013). Perkembangan suatu kota dapat meningkatkan aktivitas yang terjadi di dalamnya. Pembangunan membuka peluang terjadinya perubahan pada keadaan lingkungan. Pembangunan yang tidak seimbang antara keperluan ekonomi, sosial, dan ekologi mengakibatkan kualitas lingkungan kota menjadi rusak (Pramukanto dan Hidayah 2011).

Menurut Undang-Undang Nomor 26 Tahun 2007 mengenai Penataan Ruang, ruang terbuka hijau merupakan area memanjang atau mengelompok, yang penggunaannya lebih bersifat terbuka, dan merupakan tempat tumbuh tanaman alami ataupun yang sengaja ditanam. Ruang terbuka hijau atau RTH secara fungsional dan estetika merupakan sarana yang dapat memperbaiki kualitas kota secara fisik dan psikis (Dirjen PU 2008). RTH berfungsi sebagai penyaring partikel gas emisi, penyedia habitat bagi tumbuhan dan hewan, serta penyedia air bersih untuk akuifer (Hellmund dan Smith 2006).

Jalur hijau merupakan salah satu bentuk RTH yang merupakan alat efektif üntuk melindungi lingkungan (LPVC 2007). Selain fungsi ekologi, jalur hijau juga mpemiliki fungsi estetika dan sosial-ekonomi (Purnomohadi 2008). Jalur hijau falan merupakan agen pertama yang menyaring polutan udara dari emisi Kendaraan bermotor dan merupakan penyangga (buffer) untuk daerah di belakangnya (Hellmund dan Smith 2006). Jalur hijau jalan di Kelurahan Baranangsiang dikelola oleh Bidang Pertamanan, Dinas Kebersihan dan Pertamanan, Kota Bogor. Dalam proses perubahan, keselarasan antara manusia dan ekosistem perlu dipelihara (Mirsa 2012). Oleh sebab itu, pengelolaan jalur hijau jalan di Kelurahan Baranangsiang harus dikelola sesuai dengan standar agar jalur hijau dapat berfungsi dengan optimal.

\section{Tujuan}

Tujuan penelitian ini adalah sebagai berikut:

9. menginventarisasi jalur hijau jalan di Kelurahan Baranangsiang;

2. mengevaluasi pengelolaan jalur hijau jalan di Kelurahan Baranangsiang;

3. menyusun strategi pengelolaan jalur hijau jalan di Kelurahan Baranangsiang;

4. menyusun rencana pengelolaan jalur hijau jalan di Kelurahan Baranangsiang.

\section{Manfaat}

Manfaat dari kegiatan penelitian ini adalah memberikan alternatif strategi Gagi pengelolaan jalur hijau jalan di Kelurahan Baranangsiang, Kota Bogor. 


\section{Kerangka Pikir}

Diperlukan alternatif strategi pengelolaan untuk mengoptimalisasikan sumber daya dan peluang yang dimiliki oleh Dinas Kebersihan dan Pertamanan, Kota Bogor, selaku pihak pengelola, serta mengatasi kendala yang dihadapi. Salah satu alternatif strategi pengelolaan yang dihasilkan adalah rekomendasi rencana pengelolaan. Bagan kerangka pikir dari penelitian disajikan dalam Gambar 1.

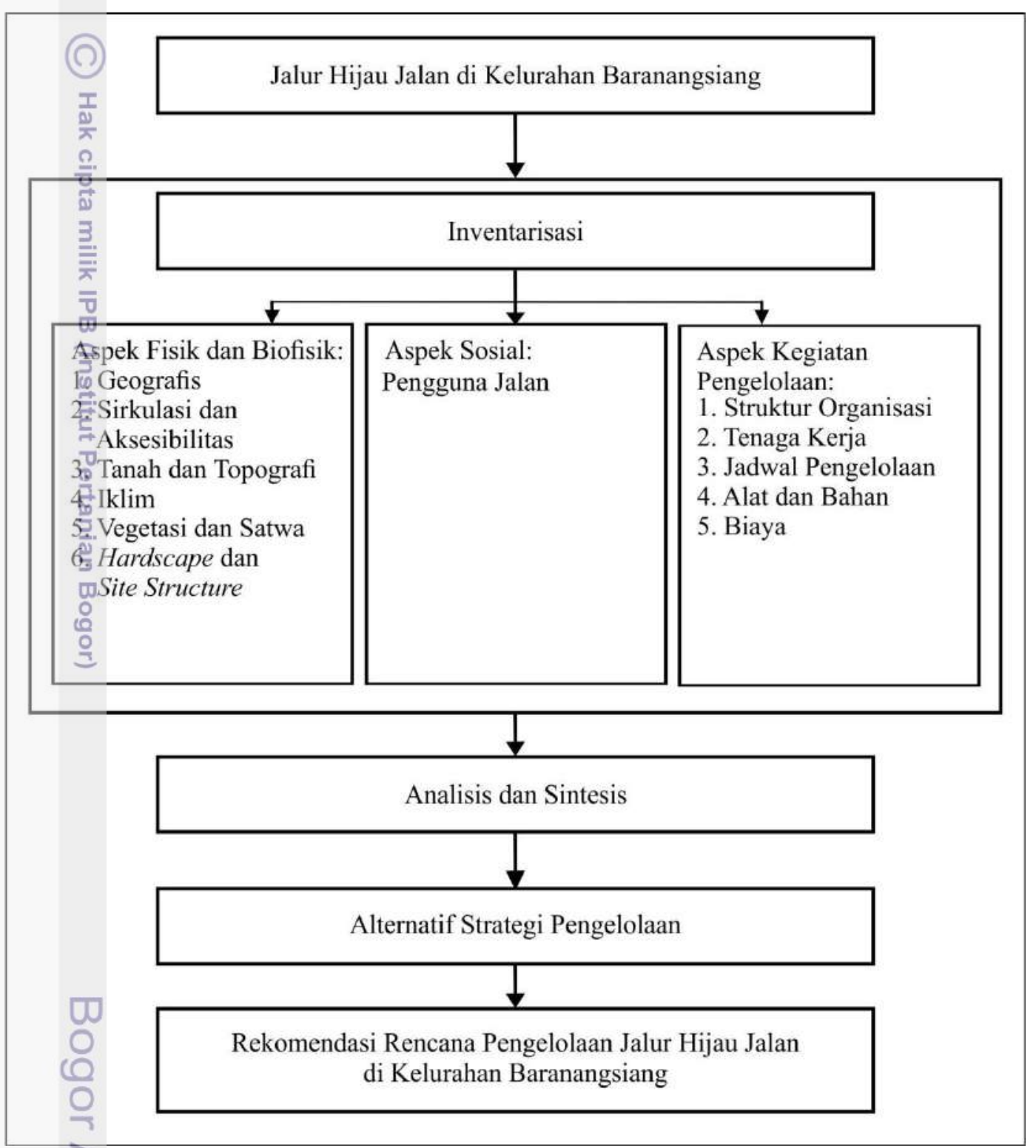

Gambar 1 Bagan kerangka pikir pengelolaan jalur hijau jalan di Kelurahan Baranangsiang 


\section{TINJAUAN PUSTAKA}

\section{Lanskap Jalan}

Jalan adalah prasarana transportasi darat yang meliputi segala bagian jalan, termasuk bangunan pelengkap dan perlengkapannya (Perda Kota Bogor No. 8 Tahun 2011; PP No. 34 Tahun 2006). Jalan sebagai sarana transportasi utama perhubungan darat merupakan akses sirkulasi yang penting dalam menunjang aktivitas suatu kawasan (Simonds dan Starke 2006). Menurut Harris dan Dines (1988), sistem jaringan jalan terbagi menjadi empat kategori, yaitu sistem jalan tol freeway system), sistem jalan arteri primer (major arterial system), sistem jalan kolektor (collector street system), dan sistem jalan lokal (local street system). Berdasarkan Peraturan Pemerintah No. 34 Tahun 2006 mengenai Jalan, bagianĔagian jalan terdiri dari ruang manfaat jalan (RUMAJA), ruang milik jalan (RUMIJA), dan ruang pengawasan jalan (RUWASJA). Ilustrasi bagian-bagian jălan disajikan pada Gambar 2.

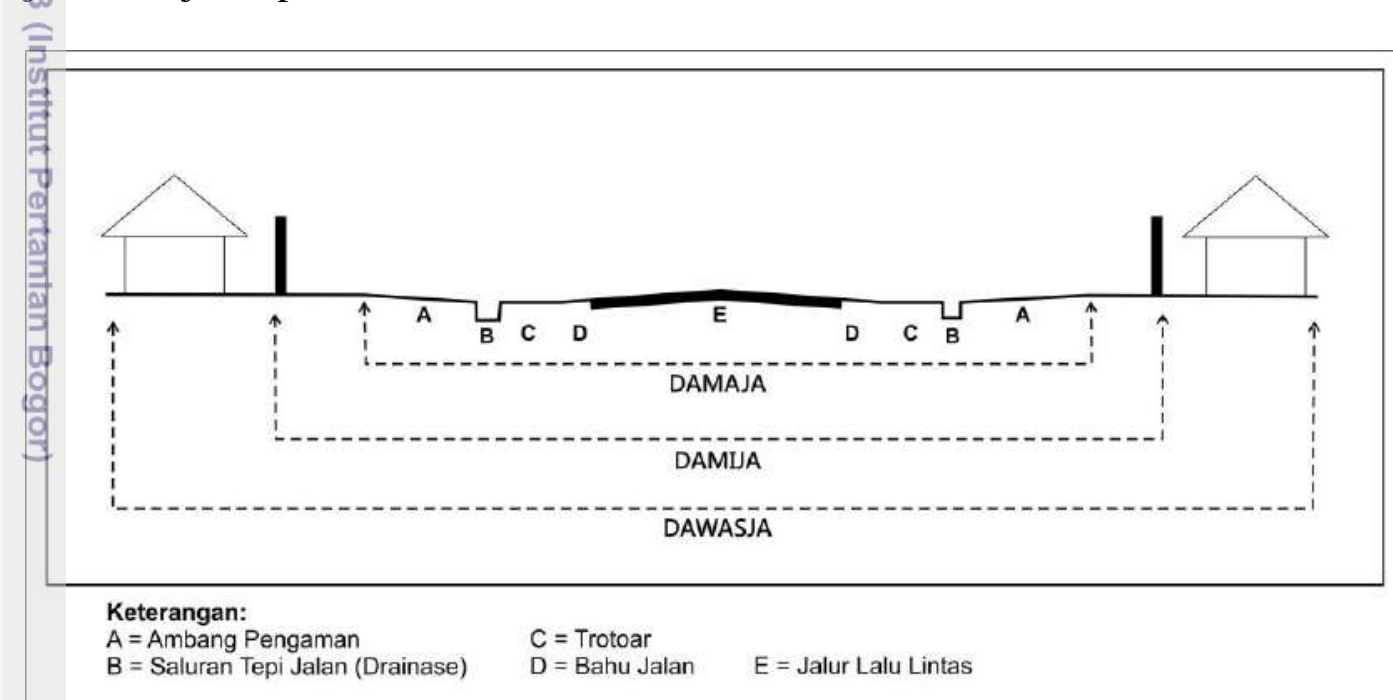

Gambar 2 Ilustrasi bagian-bagian jalan

RUMAJA merupakan ruang sepanjang jalan yang dibatasi oleh lebar, tinggi dan kedalaman tertentu yang ditetapkan oleh penyelenggara jalan tersebut. RUMAJA hanya diperuntukkan bagi median, perkerasan jalan, jalur pemisah, bahu jalan, saluran tepi jalan (drainase), trotoar, lereng, ambang pengaman, timbunan dan galian, gorong-gorong, pelengkap jalan, dan bangunan pelengkap tainnya. RUMIJA merupakan dua jalur yang terletak di kiri dan kanan jalan yang dibatasi oleh pagar pengaman jalan. RUMIJA diperuntukkan bagi ruang manfaat Galan, pelebaran jalan, dan penambahan jalur lalu lintas di masa akan datang serta kebutuhan ruangan untuk pengamanan jalan. RUWASJA merupakan ruang tertentu di luar RUMIJA yang penggunaannya berada dibawah pengawasan penyelenggara jalan (PP No. 34 Tahun 2006).

Lanskap jalan merupakan wajah dari lahan atau tapak yang terbentuk pada lingkungan jalan, baik yang terbentuk dari elemen lanskap alamiah maupun yang terbentuk dari elemen lanskap buatan manusia. Lanskap jalan memiliki ciri khas 
karena harus disesuaikan dengan persyaratan geometrik jalan dan diperuntukkan bagi kenyamanan pengguna jalan (Dirjen PU 2008). Menurut Simonds dan Starke (2006), lanskap jalan berperan dalam membangun karakter lingkungan, spasial, dan visual. Aktivitas manusia pada lanskap jalan dapat mengakibatkan pencemaran, penurunan kualitas lingkungan dan ketidaknyamanan bagi pengguna tapak.

\section{Ruang Terbuka Hijau}

Ruang terbuka (open space) menurut Dinas Pertamanan dan Keindahan Kota DKI Jakarta (2001) adalah lahan tanpa atau dengan sedikit bangunan dan lahan dengan jarak bangunan yang saling berjauhan. Ruang terbuka merupakan salah satu jaringan yang menghubungkan antarfungsi utama dan antarfungsi kegiatân dalam kota (Mirsa 2012) yang terdiri atas beberapa komponen, yaitu taman jalur hijau, dan lahan pertanian (LVPC 2007). Menurut Simonds dan Starker(2006), ruang terbuka dapat berupa waterfront (kawasan pantai, tepian danau dan tepian aliran sungai), blueways (aliran sungai dan hamparan banjir jogging track). Ruang terbuka juga dapat diartikan sebagai ruang di luar banguñan yang terbagi menjadi ruang terbuka hijau dan ruang terbuka non-hijau (Lusetyowati 2011).

Ruang terbuka hijau atau yang selanjutnya disebut RTH dapat bersifat publik ataupun privat. Ruang terbuka hijau privat adalah RTH milik institusi tertentu atau orang perseorangan yang pemanfaatannya untuk kalangan terbatas. Pemanfaatan RTH privat dapat berupa kebun atau halaman belakang dari rumah/ bangưnan milik masyarakat/ swasta. Ruang terbuka hijau publik merupakan RTH yang Jimiliki dan dikelola oleh pemerintah daerah kota/ kabupaten yang digunakan untuk kepentingan masyarakat secara umum. Proporsi RTH pada wilayah kota paling sedikit sebesar 30\% dari luas wilayah kota dengan proporsi RTH publik paling sedikit sebesar 20\% dari luas wilayah kota (Dirjen PU 2008). RTH harus diintegrasikan dengan rencana tata ruang kota, tata ruang wilayah, dan rencana tata ruang regional sebagai satu kesatuan sistem (Joga dan Ismaun 2011).

Menurut LPL (2005), RTH memiliki empat fungsi, yaitu memperbaiki kualitas lingkungan, modifikasi iklim mikro (fungsi ameliorasi iklim), membentuk ruang (fungsi arsitektural), dan menambah nilai estetika. Dalam suatu wilayah perkotaan, empat fungsi RTH tersebut dapat dikombinasikan sesuai dengan kebutuhan, kepentingan, dan keberlanjutan kota. Saat ini, kuantitas dan kualitas ruang terbuka publik terutama RTH mengalami penurunan yang sangat signifikan sehingga mengakibatkan penurunan kualitas lingkungan hidup perkotaan. Hal ini berdampak ke berbagai sendi kehidupan perkotaan, yaitu meningkatnya intensitas bencana banjir, meningkatnya pencemaran udara, dan menurunnya produktivitas masyarakat akibat terbatasnya ruang yang tersedia untuk interaksi sosial (Lusetyowati 2011).

- Berdasarkan kepemilikan RTH, RTH terbagi menjadi empat kategori, yaitu RTH pekarangan, RTH taman kota dan hutan kota, RTH jalur hijau jalan, dan RTH fungsi tertentu. Bentuk dari RTH pekarangan adalah RTH pekarangan rumah tinggal, halaman perkantoran, dan taman atap bangunan (roof garden). 
Bentuk dari RTH taman dan hutan kota adalah taman RT, taman RW, taman kelurahan, taman kecamatan, hutan kota, taman kota, dan sabuk hijau (green belt). Bentuk dari RTH jalur hijau jalan adalah pulau jalan, median, dan RTH di bawah jalan layang. Bentuk dari RTH fungsi tertentu adalah pemakaman dan RTH sempadan rel kereta api (Dirjen PU 2008).

\section{Jalur Hijau Jalan}

Joga dan Ismaun (2011) membagi jalur hijau menjadi tiga kategori, yaitu jalur hijau tepian air, jalur hijau pengaman, dan jalur hijau jalan. Jalur hijau jalan adalah jalur penempatan tanaman serta elemen lanskap lainnya yang terletak di đảam RUMIJA ataupun di dalam RUWASJA. Jalur hijau jalan terdiri dari jalur fijau tepi jalan, median, dan pulau jalan (Dirjen PU 2008). Ilustrasi jalur hijau disajikan pada Gambar 3.
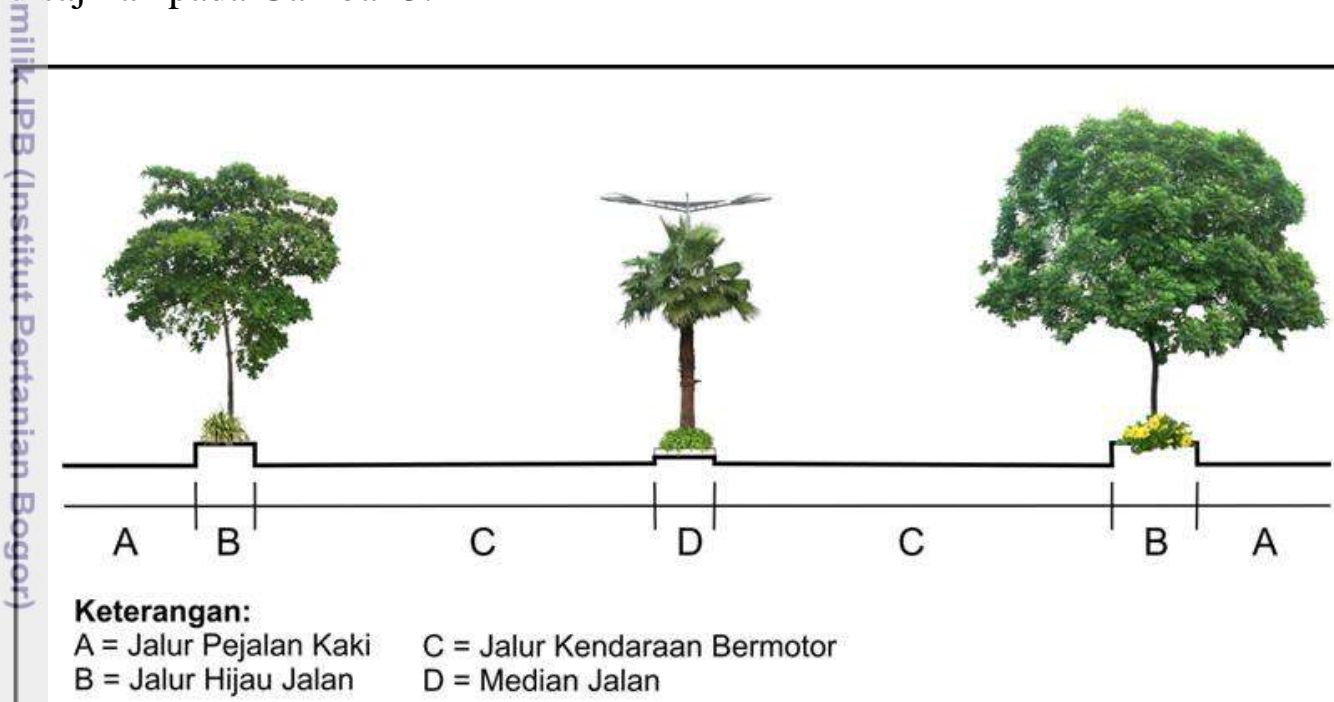

Keterangan:

$A=$ Jalur Pejalan Kaki $\quad C=$ Jalur Kendaraan Bermotor

$\mathrm{B}=$ Jalur Hijau Jalan $\quad \mathrm{D}=$ Median Jalan

Gambar 3 Ilustrasi jalur hijau jalan

Pulau jalan adalah RTH yang terbentuk oleh geometris jalan seperti pada persimpangan tiga atau bundaran jalan. Median merupakan jalur pemisah yang membagi jalan menjadi dua lajur atau lebih. Median dapat digunakan sebagai tempat untuk meletakkan rambu-rambu lalu lintas atau tanaman dengan persyaratan tertentu (Dirjen PU 2008). Jalur hijau jalan merupakan public goods, Oleh sebab itu, penataan tanamannya dibuat secara masal dan memiliki keragaman Elemen taman yang tidak terlalu tinggi. Hal ini bertujuan agar tingkat pemeliharaannya dapat dilakukan secara semi-intensif (Arifin dan Arifin 2005).

\section{Fungsi Tanaman dalam Lanskap}

Tanaman sebagai salah satu elemen ruang luas yang utama dapat difungsikan untuk merekayasa lingkungan (Nurisjah dan Pramukanto dalam Femy 2014). Tanaman dalam jalur hijau memiliki fungsi yang beragam, yaitu sebagai peneduh, pengarah jalan, penyerap polusi udara, peredam kebisingan, pemecah angin, dan border atau pembatas (Dept. PU 1996; Kencana dan Lestari 2002; 
Dirjen PU 2008). Tanaman peneduh merupakan jenis tanaman berbentuk pohon yang tingginya lebih dari $2 \mathrm{~m}$ dan dapat memberikan keteduhan. Tanaman pengarah jalan merupakan tanaman berbentuk pohon atau perdu yang diletakkan berkelompok dengan komposisi tertentu (Dept. PU 1996). Secara psikologis, tanaman dapat berfungsi sebagai pengarah jika ditanam pada jarak dan dengan pola tertentu (Kencana dan Lestari 2008).

Tanaman penyerap polusi adalah jenis tanaman berbentuk pohon atau perdu yang memiliki masa daun padat dan dapat menyerap polusi udara yang ditimbulkan kendaraan bermotor (Dept. PU 1996). Tanaman penyerap polusi memiliki tepi daun yang kasar/ bergerigi/ bersisik/ berbulu. Tanaman peredam kebisin̄gan merupakan tanaman yang memiliki karakteristik tertentu, seperti masa daun padat dan daun berbentuk jarum atau berbulu (Hidayat 2010). Tanaman yang berfungsi sebagai pembatas adalah jenis pohon atau perdu dengan masa daun padat. Pohon atau perdu diletakkan berdekatan atau berbaris membentuk masa padat Napisah 2009).

${ }_{\bar{Z}}^{\bar{Z}}$ Menurut Departemen Perencanan Umum (1996), penentuan jenis tanaman yang akan ditanam pada jalur tanaman tepi harus memenuhi kriteria teknik perletakan tanaman dan disesuaikan dengan lebar jalur tanaman. Pemilihan jenis tanaman ditentukan oleh kondisi iklim habitat, dan areal peletakan tanaman dengañ memperhatikan ketentuan geometrik jalan dan fungsi tanaman. Menurut bentuknya, tanaman terdiri dari jenis pohon, perdu, semak, dan tanaman penutup permukaan tanah (ground cover).

J.Persyaratan utama yang perlu diperhatikan dalam memilih jenis tanaman lanskap jalan, adalah perakaran yang tidak merusak konstruksi jalan, perawatan yang mudah, dan percabangan serta daun yang tidak mudah rontok atau gugur. Tanangan yang ditanam juga harus toleran terhadap polusi udara dan bukan merupakan tanaman buah ataupun beracun. Lebar jalur median yang dapat ditanami harus mempunyai lebar minimum 0,80 meter, sedangkan lebar ideal adalah 4,00-6,00 meter. Pemilihan jenis tanaman perlu memperhatikan tempat perletakannya terutama pada daerah persimpangan, pada daerah bukaan ("Uturn"), dan pada tempat di antara persimpangan jalan.

Kriteria khusus untuk tanaman yang ditempatkan di median jalan tol, adalah memiliki daun berukuran kecil, merupakan tanaman yang dapat hidup terkena cahaya matahari secara langsung, mempunyai daun bersisik atau bergerigi, dan memiliki kemampuan dalam menyerap polutan. Tanaman tersebut juga harus toleran terhadap polusi udara dan kekeringan. Evaluasi tanaman diperlakan untuk mengoptimalkan efektivitas tanaman dengan mewujudkan pemenuhan fungsi arsitektural, fungsional, lingkungan, dan estetika (Napisah 2009).

\section{Pengelolaan Lanskap}

Pembangunan lanskap yang baik harus disertai pengelolaan yang baik (Parker dan Bryan 1989). Pengelolaan lanskap merupakan upaya terpadu dalam penataan dan pemanfaatan, pemeliharaan, pelestarian, pengendalian, dan pengembangan lingkungan hidup. Tujuan dari pemeliharaan dapat bervariasi, tetapi pada dasarnya memiliki tujuan yang sama, yaitu menjaga kebersihan dari 
waktu ke waktu, mengembangkan dan memelihara estetika, menciptakan lingkungan yang sehat, serta menciptakan lingkungan yang aman. Hal ini dilakukan untuk menciptakan lanskap yang bermanfaat bagi manusia dan makhluk hidup lainnya (Arifin dan Arifin 2005).

Proses pemeliharaan sehari-hari dalam bidang lanskap merupakan bagian yang membutuhkan waktu dan energi yang banyak (Parker dan Bryan 1989). Pihak pengelola harus memperhatikan frekuensi kegitan pemeliharaan agar jadwal dapat tersusun dengan rinci, dan jumlah operator pemelihara sesuai dengan kebutuhan (Arifin dan Arifin 2005). Pengelolaan merupakan salah satu kunci keberhasilan dalam suatu pembangunan. Kegiatan pengelolaan lanskap dimulai Gari tahap perencanaan program pemeliharaan, pelaksanaan kegiatan pemeliharaan dan pengawasan, serta monitoring dan evaluasi kegiatan pemeliharaan (Arifin et al 2008). Ilustrasi mengenai kegiatan pengelolaan lanskap disajikan pada Gambar 4.
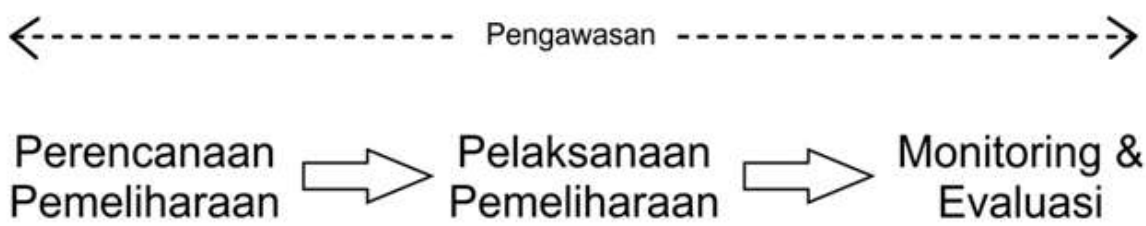

Pemeliharaan Pemeliharaan Evaluasi

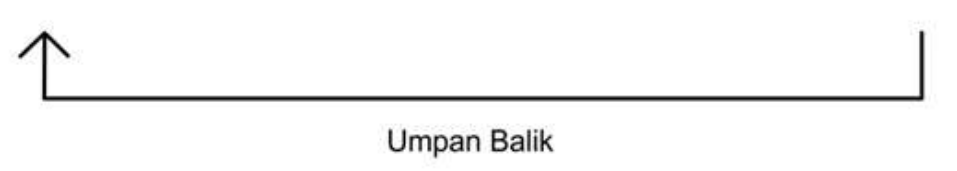

Gambar 4 Kegiatan pengelolaan menurut Arifin et al. (2008)

Kegiatan pengelolaan jalur hijau di Kelurahan Baranangsiang menjadi tanggung jawab dari Dinas Kebersihan dan Pertamanan. Menurut Larsson (2010), umumnya pemeliharaan tidak bergantung pada satu orang atau satu perusahaan. Sebagai sebuah kebijakan, banyak pihak yang terlibat dalam pengelolaan, baik dari instansi publik maupun privat. Menurut Rehman et al. (2002), masyarakat juga memiliki peran penting dalam sistem pengelolaan ruang terbuka. Keterlibatan dari masyarakat memberikan banyak keuntungan yang bersifat humanis, seperti bertambahnya rasa kepekaan antar masyarakat (Ames dalam Rehman et al. 2002).

Detil atau kompleksitas tata letak yang ada dalam tapak mempengaruhi biaya pemeliharaan (Parker dan Bryan 1989). Biaya merupakan masalah kritis dalam proses pemeliharaan (Arifin dan Arifin 2005). Oleh sebab itu, penting bagi para desainer untuk mempertimbangkan pengelolaan sejak awal proyek dan berkomunikasi dengan pihak pengelola agar tercipta pengelolaan berkelanjutan ((Booth 1983). 


\section{METODOLOGI}

\section{Lokasi dan Waktu Pelaksanaan}

Kegiatan penelitian dilaksanakan di Kelurahan Baranangsiang, Kecamatan Bogor Timur, Kota Bogor. Penelitian dilaksanakan selama lima bulan, yaitu dari bulan Januari hingga Juli 2015. Lokasi penelitian disajikan pada Gambar 5.

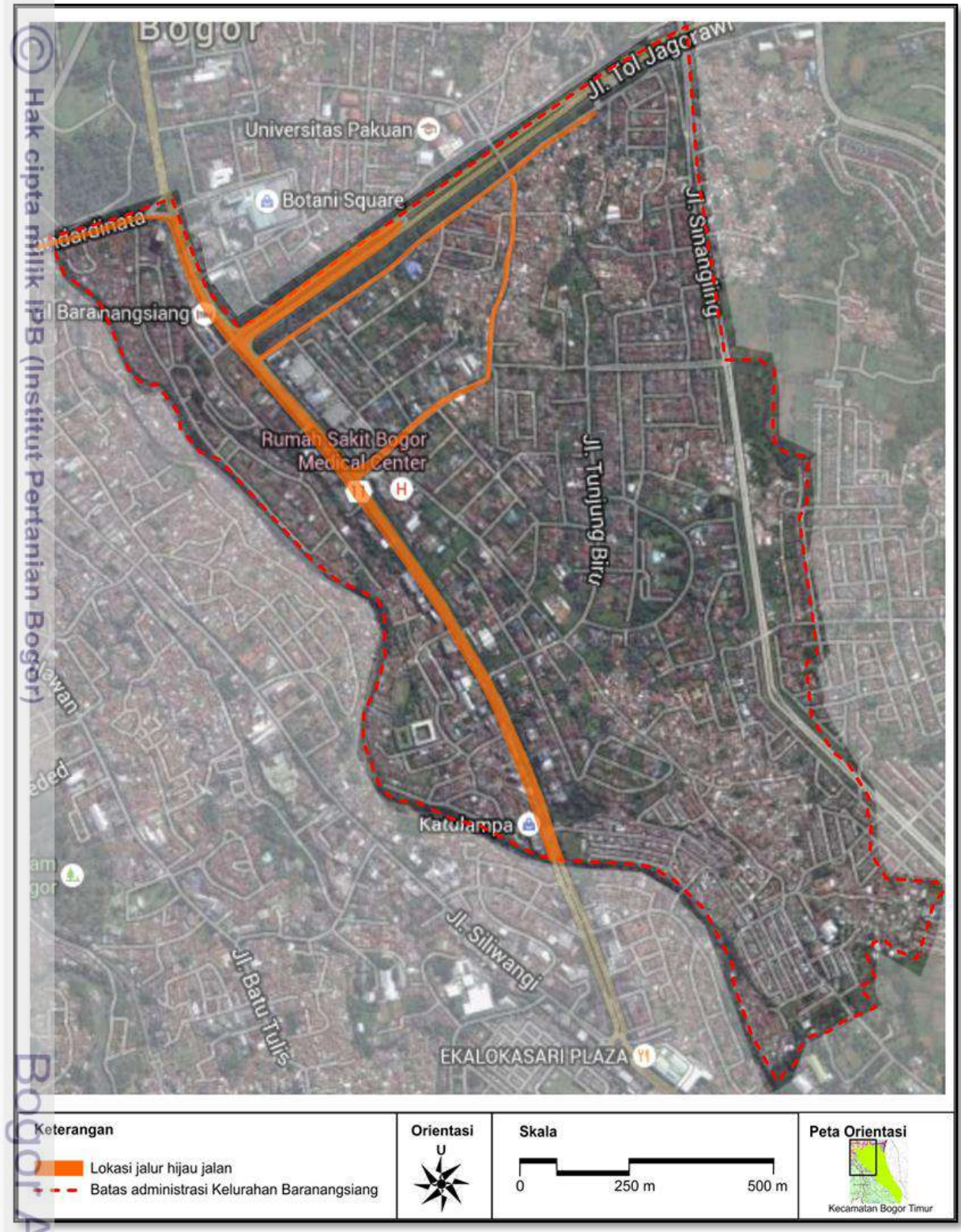

Gambar 5 Lokasi penelitian

Sumber: google earth

\section{Bahan dan Alat}

E Alat dan bahan yang dibutuhkan meliputi kamera digital, peta dasar, data biofisik, data fisik, data pengelolaan pada tapak, serta berbagai macam software pendukung, seperti Auto CAD dan Google Earth. 


\section{Batasan Penelitian}

Ruang lingkup dari penelitian ini adalah jalur hijau jalan di Kelurahan Baranangsiang yang dikelola oleh Dinas Kebersihan dan Pertamanan. Ruang lingkup dari jalur hijau yang diteliti meliputi jalur hijau di sisi kiri dan kanan jalan (tepi jalan), median, pulau jalan, dan taman sudut di Kelurahan Baranangsiang, Kecamatan Bogor Timur, Kota Bogor.

\section{Metode Penelitian}

Tahap pertama adalah melakukan segmentasi. Lokasi penelitian dibagi menjadi delapan titik lokasi, yaitu Jalan Otto Iskandardinata, Jalan Raya Pajajaran \$egmen I, Jalan Raya Pajajaran Segmen II, Jalan Raya Pajajaran Segmen III, Tol Jagorawi, Jalan Bina Marga, Jalan Padi, dan Jalan Pakuan. Jalan Raya Pajajaran dibagi menjadi tiga segmen. Pembagian Segmen dilakukan berdasarkan komposisi $\overline{\bar{v}}$ egetasi (Gambar 6).

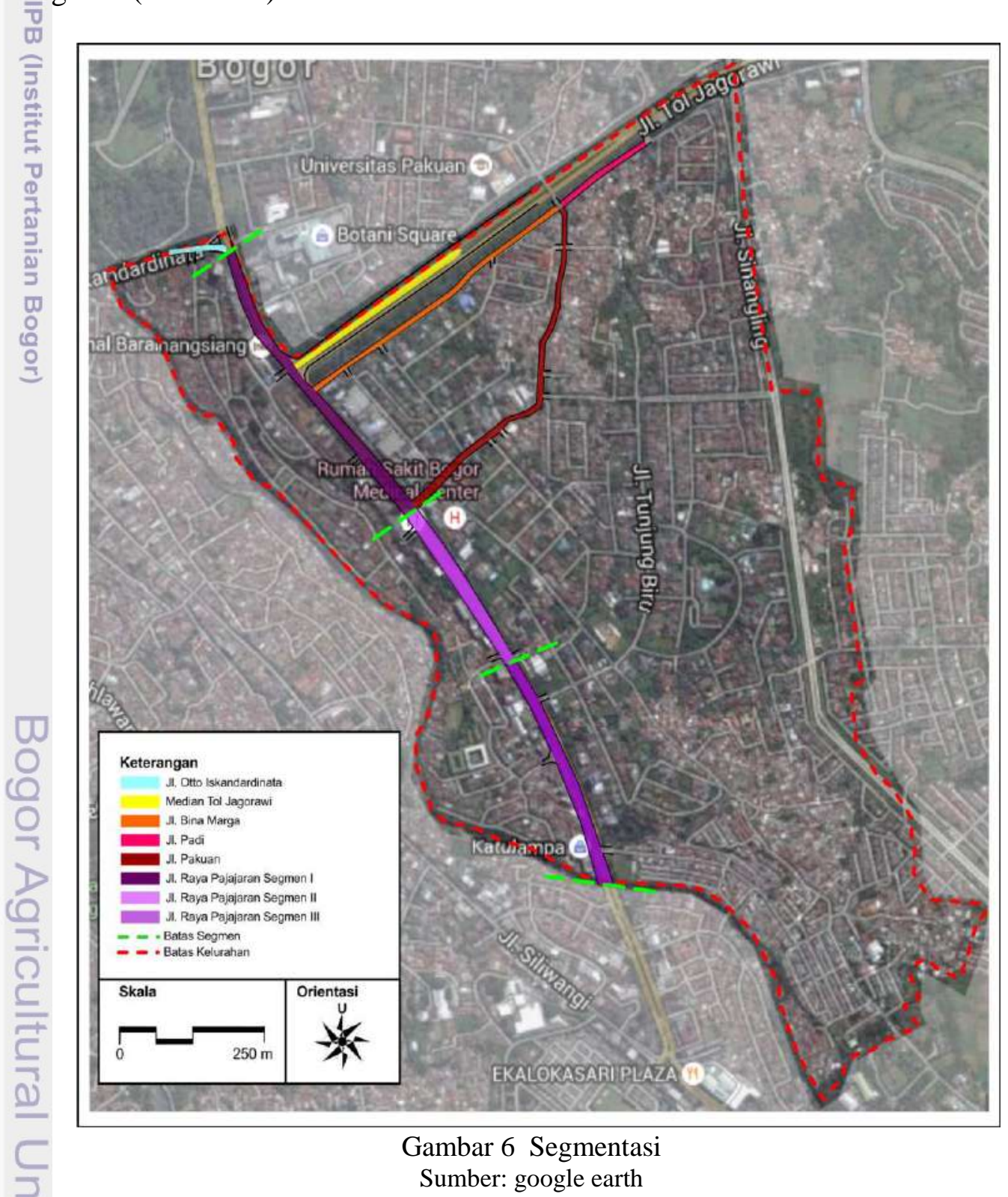


Data primer mengenai vegetasi didapat dengan melakukan pengamatan jenis, nama, dan jumlah vegetasi. Setelah itu, dilakukan pengecekan nama lokal, nama ilmiah, dan data lain yang terkait dengan tanaman dengan menggunakan galeri tanaman yang mengacu pada Ratnasari (2008), Kencana dan Lestari (2008), dan Hasim (2009). Pengambilan data mengenai kondisi site structure dan elemen perkerasan dilakukan dengan melakukan pengamatan jenis dan jumlah yang ada di tapak. Dokumentasi lapang dilakukan menggunakan kamera digital. Data sekunder dari setiap aspek diperoleh dari hasil wawancara dengan dinas terkait.

Data sosial mengenai pengguna jalan diperoleh melalui kuesioner. Wawancara dilakukan kepada pengguna jalan yang berjalan kaki (pedestrian) dan penggसna kendaraan bermotor (vehicular) baik yang menggunakan motor maupun

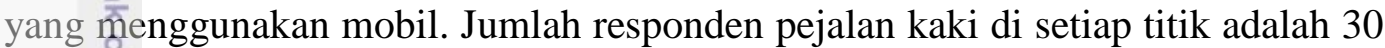
orang.:Wawancara dilakukan di semua titik lokasi kecuali Tol Jagorawi. Tujuan dari Wawancara adalah mengetahui preferensi pengguna terhadap aspek lima aspek, =yaitu aspek kebersihan, keamanan, kenyamanan, fasilitas, dan keindahan (Lampiran 3).

WWawancara dilakukan di empat titik lokasi, yaitu Jalan Raya Pajajaran Segmen I s.d. III dan Tol Jagorawi dengan jumlah responden sebanyak 30 orang di masing-masing lokasi. Wawancara yang dilakukan kepada pengguna kendaraan bermotor bertujuan mengetahui preferensi pengguna terhadap aspek keindahan, kebersithan, dan fasilitas. Selain itu, dilakukan pula wawancara mengenai pengaruth tanaman khususnya yang berada di median jalan terhadap jarak pandang pengeñdara kendaraan bermotor. Fasilitas yang ada di jalan raya ataupun jalan tol khusus̄nya fasilitas berupa marka jalan tidak boleh terhalang oleh tanaman, banguanan atau site structure, dan harus terlihat dalam jarak $100 \mathrm{~m}$ (Aram 2010). Oleh sebab itu, dilakukan wawancara mengenai daya tangkap (sight) pengendara terhadāp fasilitas yang terdapat pada tapak. Wawancara dilakukan kepada pengendara mobil dan motor. Kuesioner untuk pengguna kendaraan bermotor disajikan pada Lampiran 4. Data yang diperlukan disajikan dalam Tabel 1.

Tabel 1 Data yang diperlukan dalam penelitian

\begin{tabular}{|c|c|c|c|c|}
\hline No. & Jenis Data & Data yang Diambil & Bentuk Data & Sumber Data \\
\hline \multirow[t]{9}{*}{1} & \multirow{9}{*}{ Fisik dan biofisik } & a. Geografi & Primer dan & a. BAPPEDA \\
\hline & & b. Sirkulasi dan & \multirow{8}{*}{ Sekunder } & b. Kecamata \\
\hline & & Aksesibilitas & & Bogor \\
\hline & & c. Vegetasi dan Satwa & & Timur \\
\hline & & d. Hardscape dan Site & & c. Dinas \\
\hline & & Structure & & Kebersihan \\
\hline & & e. Iklim & & dan \\
\hline & & f. Tanah dan & & Pertamanan \\
\hline & & Topografi & & \\
\hline 2 & OSosial & Pengguna jalan & Primer & Wawancara \\
\hline \multirow[t]{5}{*}{3} & \multirow{5}{*}{$\overline{\bar{O}}$ Pihak pengelola } & a. Struktur Organisasi & Primer dan & Dinas \\
\hline & & b. Jadwal Kegiatan & Sekunder & Kebersihan \\
\hline & & c. Alat dan Bahan & & dan \\
\hline & & d. Tenaga Kerja & & Pertamanan \\
\hline & & e. Biaya & & \\
\hline
\end{tabular}




\section{Tahapan Penelitian}

Tahapan penelitian terdiri dari tahap persiapan dan inventarisasi, serta analisis dan sintesis. Metode analisis yang digunakan adalah metode deskriptif dan SWOT.

\section{Persiapan dan Inventarisasi}

Pada tahap ini dilakukan persiapan meliputi penyusunan proposal usulan penelitian, penyusunan kuesioner, pengurusan perizinan dari instansi yang dituju, serta persiapan berbagai macam alat dan bahan yang digunakan dalam penelitian. Selain itu, dilakukan pencarian informasi umum tentang kondisi jalur hijau di Kelurahan Baranangsiang. Data inventarisasi berasal dari data primer dan sèkunder.

\section{Analisis dan Sintesis}

Analisis yang digunakan adalah analisis deskriptif dan analisis SWOT. Analisis deskriptif bertujuan untuk menjabarkan hasil pengamatan data yang diperoleh melalui pengamatan langsung di lapang, wawancara, serta studi pustaka. Dalam analisis aspek sosial, dilakukan analisis preferensi pengguna untuk mengetahui persepsi pengguna jalan terhadap jalur hijau jalan yang ada di Kelurahan Baranangsiang. Hasil wawancara akan menjadi saran bagi Dinas Kebersihan dan Pertamanan sebagai pihak pengelola.

Menurut Rangkuti (1997), analisis SWOT adalah identifikasi berbagai faktor secara sistematis untuk merumuskan strategi perusahaan atau institusi, yang didasarkan pada logika yang dapat memaksimalkan kekuatan (strengths) dan peluang (opportunities) dan secara bersamaan meminimalkan kelemahan (weaknesses) beserta ancaman (threats).

Langkah pertama dalam analisis SWOT adalah menganalisis penilaian faktor internal yang terdiri atas kekuatan dan kelemahan, serta menganalisis penilaian faktor eksternal yang terdiri atas peluang dan ancaman. Langkah selanjutnya adalah menentukan nilai kepentingan dari setiap variabel berdasarkan hasil diskusi dengan pihak pengelola. Masing-masing bobot diberikan mulai dari 4,0 (sangat penting) sampai 1,0 (tidak penting).

Langkah ketiga adalah menentukan bobot setiap variabel dengan menggunakan metode paired comparison (Kinnear dan Taylor 1991), dengan ketentuan:

1. bobot 1 jika indikator faktor horizontal kurang penting dibandingkan faktor vertikal,

2. bobot 2 jika indikator faktor horizontal sama penting dibandingkan faktor vertikal,

3. bobot 3 jika indikator faktor horizontal lebih penting dibandingkan faktor vertikal, dan

4. bobot 4 jika indikator faktor horizontal sangat lebih penting dibandingkan faktor vertikal.

Contoh penentuan bobot strategis setiap variabel disajikan pada Tabel 2. 
Tabel 2 Contoh penilaian bobot strategis faktor internal

Faktor Internal

(a)

(b)

S2

(c)

(d) W2

(e)

(f)

\begin{tabular}{l|l|l|l|} 
S1 & \\
S2 & \\
W1 & & \\
W2 & & \\
\hline
\end{tabular}

Total keseluruhan

Sumber: Kinnear dan Taylor (1991) dengan penyesuaian

Keterangan:

Simbol (a) hingga (d)

(e) Total

(f) Bob̈ot

$=$ nilai dari paired comparison.

$=$ jumlah nilai pada satu baris

$=$ hasil bagi dari nilai pada setiap kolom total (e)

dengan nilai keseluruhan kolom total (g)

TProses identifikasi dari masing-masing faktor dilakukan oleh tiga dinas terkait, yaitu Bidang Pertamanan dari Dinas Kebersihan dan Pertamanan, Kelurāhan Baranangsiang, dan Kecamatan Kota Bogor Timur. Bobot dari setiap faktor diberikan oleh Bidang Pertamanan. Langkah selanjutnya adalah membuat Matriks Internal Factor Evaluation (IFE) dan Matriks External Factor Evaluation (EFE) Matriks ini menunjukkan tingkat kepentingan dari setiap faktor. Rating yang diberikan terhadap masing-masing faktor dikalikan dengan masing-masing bobot untuk पmenghasilkan skor. Contoh Matriks Internal Factor Evaluation (IFE) disajikan pada Tabel 3 .

Tabel 3 Contoh Matriks Internal Factor Evaluation (IFE)

\begin{tabular}{cccccc}
\hline Simbol & Faktor Internal & $\begin{array}{c}\text { Tingkat } \\
\text { Kepentingan }\end{array}$ & Rating & Bobot & Skor \\
\hline S1 & & & & \\
S2 & & & \\
W1 & & & \\
W2 & & & \\
\hline
\end{tabular}

Total

Sumber: David (2008) dengan penyesuaian

Keterangan:

Simbol S1--W2 = simbol kekuatan dan kelemahan dari setiap faktor

Faktorinternal = menjelaskan setiap faktor internal

Tingkat kepentingan $=$ penilaian kepentingan setiap faktor

Rating = angka penilaian kepentingan setiap faktor

Bobot. $\quad=$ bobot setiap faktor sesuai paired comparison

Skor

$=$ nilai setiap rating $\mathrm{x}$ nilai setiap bobot

Total $=$ jumlah keseluruhan skor

Langkah kelima adalah membuat Matriks Internal-Eksternal. Hal ini dilakukan untuk mengetahui tipe strategi yang sesuai untuk mengatasi 
permasalahan. Terdapat tiga tipe strategi, yaitu grow and build (Sel I, II, dan IV), hold and maintain (Sel III, V, dan VII), serta harvest or divest (Sel VI, VIII, dan IX). Fokus dari strategi grow and build adalah penetrasi pasar, pengembangan pasar, dan pengembangan produk yang bersifat intensif dan agresif. Strategi hold and maintain terfokus pada penetrasi pasar dan pengembangan produk. Fokus strategi harvest and divest adalah perlunya manajemen biaya yang agresif saat biaya peremajaan tergolong rendah. Matriks Internal-Eksternal disajikan pada Tabel 4.

Tabel 4 Matriks Internal-Eksternal

\begin{tabular}{|c|c|c|c|c|}
\hline \multicolumn{2}{|c|}{ Total Skor EFE } & $\begin{array}{c}\text { Kuat } \\
(3,00-4,00)\end{array}$ & $\begin{array}{c}\text { Rata-rata } \\
(2,00-2,99)\end{array}$ & $\begin{array}{c}\text { Lemah } \\
(1,00-1,99)\end{array}$ \\
\hline 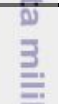 & $\begin{array}{c}\text { Tinggi } \\
(3,00-4,00)\end{array}$ & I & II & III \\
\hline $\begin{array}{l}\bar{\pi} \\
\overline{\bar{\sigma}} \\
\text { ๘ }\end{array}$ & $\begin{array}{c}\text { Menengah } \\
(2,00-2,99)\end{array}$ & IV & V & VI \\
\hline$\widehat{\bar{z}}$ & $\begin{array}{c}\text { Rendah } \\
(1,00-1,99)\end{array}$ & VII & VIII & IX \\
\hline
\end{tabular}

Langkah selanjutnya adalah membuat Matriks SWOT dengan menggabungkan faktor-faktor internal dan faktor-faktor eksternal. Tahap ini dilakukan üntuk menyesuaikan kekuatan dan kelemahan yang dimiliki dengan peluang dan ancaman yang diprediksi akan terjadi (Tabel 5).

Tabel 5 Contoh Matriks SWOT

\begin{tabular}{lllll}
\hline Faktor Eksternal & \multicolumn{2}{c}{ Opportunities $(\mathrm{O})$} & \multicolumn{2}{c}{ Threats $(\mathrm{T})$} \\
& $\begin{array}{l}\text { 1. } \\
\text { Faktor Internal }\end{array}$ & 2. & & \\
\hline Strengths $(\mathrm{S})$ & & Strategi S-O & \multicolumn{2}{c}{ Strategi S-T } \\
1. & 1. & & 1. & \\
2. & 2. & & 2. & \\
Weaknesses $(\mathrm{W})$ & & Strategi W-O & & Strategi W-T \\
1. & 1. & & 1. & \\
2. & 2. & 2. & \\
\hline
\end{tabular}

Sumber: David (2008) dengan penyesuaian

Berdasarkan Matriks SWOT, terdapat empat jenis strategi yang dapat dihasilkan untuk menyelesaikan permasalahan dengan mempertimbangkan masing-masing faktor (Rangkuti 1997):

a. S-O (strengths-opportunities), yaitu strategi yang memanfaatkan seluruh kekuatan untuk memanfaatkan peluang sebesar-besarnya,

b. S-T (strengths-threats), yaitu strategi yang memanfaatkan kekuatan yang dimiliki untuk mengatasi ancaman,

a. W-O (weaknesses-opportunities), yaitu strategi yang meminimalisir kelemahan untuk memanfaatkan peluang, dan 
b. W-T (weaknesses-threats), strategi yang meminimalisir kelemahan dan menghindari ancaman.

Setelah didapatkan alternatif strategi, dilakukan penentuan peringkat dari setiap alternatif strategi dengan cara menjumlahkan semua skor dari setiap faktor strategis yang terkait. Setelah didapatkan alternatif stategi, dilakukan penyusunan rekomendasi pengelolaan jalur hijau jalan di Kelurahan Baranangsiang yang meliputi lima aspek, yaitu struktur organisasi, tenaga kerja, jadwal kerja, alat dan bahan, serta biaya yang mengacu pada pengelolaan Arifin dan Arifin (2005).

\section{HASIL DAN PEMBAHASAN}

\section{Inventarisasi}

\section{Aspek Fisik dan Biofisik}

\section{${ }_{=}^{\bar{Z}}$ Geografis}

WLokasi Kelurahan Baranangsiang terletak di Kecamatan Bogor Timur, Kota Bogor, dengan luas wilayah sebesar 235 ha. Batas utara Kelurahan Baranângsiang adalah Kelurahan Tegalega dan Kelurahan Paledang. Sebelah timur berbatasan dengan Kelurahan Tanah Baru dan Kelurahan Katulampa. Sebelah selatan berbatasan dengan Kelurahan Sukasari dan Kelurahan Lawagintung. Sebelah barat berbatasan dengan Kelurahan Babakan Pasar dan Kelurahan Sukasari. Ruang terbuka hijau di Kelurahan Baranangsiang didominasi oleh rütang terbuka hijau privat. Ruang terbuka hijau yang dikelola oleh Dinas Kebersihan dan Pertamanan di Kelurahan Baranangsiang memiliki luas sebesar $22.60 \$ \mathrm{~m}^{2}$ (Tabel 6). Kondisi jalur hijau jalan secara umum dapat dilihat pada Lampiran 1.

Tabel 6 Lokasi jalur hijau jalan di Kelurahan Baranangsiang

\begin{tabular}{rlrrl}
\hline No. & Lokasi Jalur Hijau Jalan & Luas $\left(\mathrm{m}^{2}\right)$ & Luas $(\%)$ & Jenis Jalur Hijau \\
\hline 1 & Jalan Raya Pajajaran & 17876,12 & $\begin{array}{c}79,08 \\
\text { Tepi jalan, median, dan pulau } \\
\text { jalan }\end{array}$ \\
2 & Tol Jagorawi & 2259,00 & 9,99 Median dan pulau jalan \\
3 & Jalan Bina Marga & 816,42 & 3,61 Tepi jalan dan taman sudut \\
4 & Jalan Padi & 618,70 & 2,74 Tepi jalan \\
5 & Jalan Pakuan & 623,00 & 2,76 Median \\
6 & Salan Otto & 411,04 & 1,82 Tepi jalan \\
& Iskandardinata & & & \\
\hline & Total & 22604,28 & 100,00 & \\
\hline
\end{tabular}

Sumber: Dinas Kebersihan dan Pertamanan, dan hasil pengamatan di lapang

\section{Sirkutasi dan Aksesibilitas}

Sirkulasi di Jalan Otto Iskandardinata, Jalan Raya Pajajaran, Jalan Bina Marga, Jalan Padi, dan Jalan Pakuan terdiri dari sirkulasi untuk kendaraan bermetor dan pejalan kaki. Tampak potongan pada tapak disajikan pada Lampiran 
2. Sirkulasi di Tol Jagorawi hanya terdiri atas sirkulasi untuk kendaraan bermotor (Gambar 7).

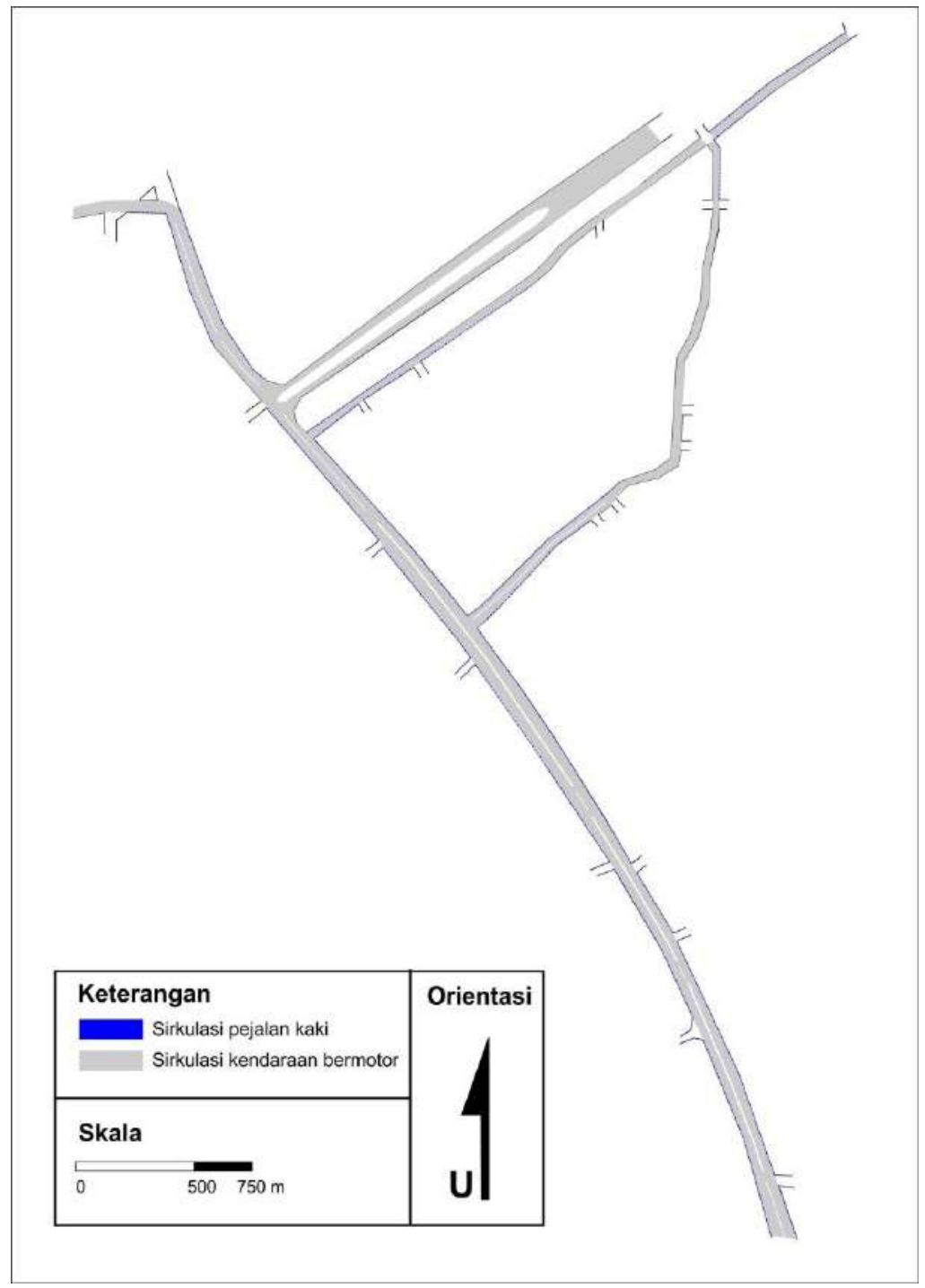

Gambar 7 Sirkulasi

Berdasarkan Rencana Tata Ruang Wilayah (RTRW) Kota Bogor Tahun 2011-2031, mengenai sistem transportasi Kota Bogor, Kelurahan Baranangsiang memiliki beberapa jenis jaringan jalan (Tabel 7).

Tabel 7 Jenis jaringan jalan

\begin{tabular}{|c|c|c|c|}
\hline No. & Lokasi Jalur Hijau Jalan & Jenis Jaringan Jalan & Lalu lintas Angkutan Umum \\
\hline$\frac{01}{2}$ & Jalan Raya Pajajaran & Jalan arteri & Dilalui angkutan umum \\
\hline & Tol Jagorawi & Jalan tol & Tidak dilalui angkutan umum \\
\hline-3 & Jalan Bina Marga & Jalan kolektor & Dilalui angkutan umum \\
\hline 4 & Jalan Padi & Jalan kolektor & Dilalui angkutan umum \\
\hline$\subset 5$ & Jalan Pakuan & Jalan kolektor & Dilalui angkutan umum \\
\hline$\sqrt{6} 6$ & Jalan Otto Iskandardinata & Jalan arteri & Dilalui angkutan umum \\
\hline
\end{tabular}


Tipikal jalan dari setiap lokasi berbeda-beda. Ilustrasi tipikal jalan disajikan pada Gambar 8.

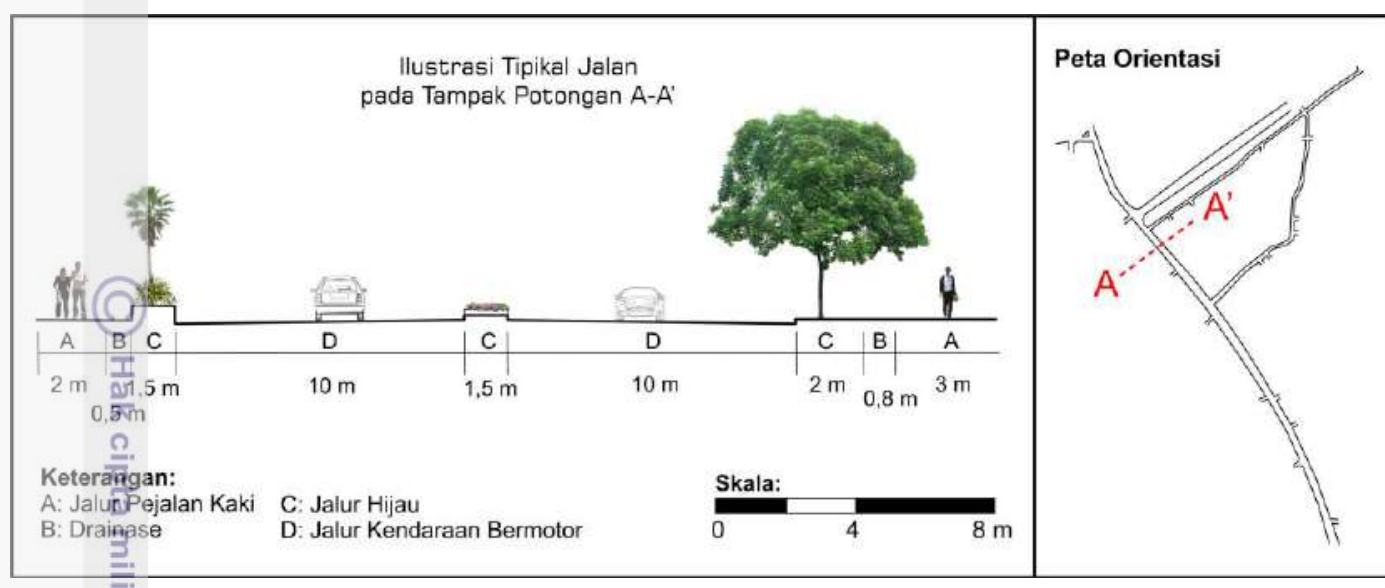

Gambar 8 Ilustrasi tipikal jalan

Tanah dan Topografi

Struktur tanah yang terdapat di Kelurahan Baranangsiang adalah Latosol dengan ketinggian lahan berkisar antara 250 dan 350 mdpl. Kemiringan lahan di Kota Bogor terbagi menjadi 5 kategori, yaitu datar (0--2\%), landai (2--15\%), agak curam $(15--25 \%)$, kategori curam (25--40\%), dan sangat curam (>40\%). Kemirïngan lahan di Kelurahan Baranangsiang tergolong dalam kategori datar dan landai

ए

\section{Iklim}

Kota Bogor memiliki curah hujan tinggi dengan curah hujan rata-rata 3.000-4.000 mm pertahun dan 250-335 mm perbulan. Curah hujan maksimum terjadi pada bulan Oktober, sedangkan curah hujan minimum terjadi pada bulan September. Suhu rata-rata berkisar $26^{\circ} \mathrm{C}$ dengan suhu tertinggi sekitar $30,4^{\circ} \mathrm{C}$. Kelembaban udara rata-rata kurang lebih $70 \%$ dengan kecepatan angin rata-rata 2 $\mathrm{km} / \mathrm{jam}$ pertahun.

\section{Vegetasi dan Satwa}

Jumlah dan jenis vegetasi di jalur hijau jalan Kelurahan Baranangsiang berbeda-beda di setiap titik lokasi. Jenis vegetasi di jalur hijau Jalan Raya Pajajaran Segmen I terdiri dari 11 jenis pohon, 5 jenis perdu, 11 jenis semak, 10 jenis ground cover, dan 1 jenis tanaman merambat. Jenis dan jumlah vegetasi eksisting pada tapak disajikan pada Tabel 8. Satwa yang terdapat dalam tapak adalah kupu-kupu.

Tabel 8 Vegetasi eksisting di jalur hijau Jalan Raya Pajajaran Segmen I

\begin{tabular}{lllrrr}
\hline No. Gambar & Nama Latin & Nama Lokal & Jumlah & Satuan & Lokasi \\
\hline Pohon- & & & & & \\
1 & Cerbera manghas & Bintaro & 7,0 & Pohon & Median \\
& & & & & \\
\hline
\end{tabular}


Tabel 8 Vegetasi eksisting di jalur hijau Jalan Raya Pajajaran Segmen I (lanjutan)

\begin{tabular}{|c|c|c|c|c|c|c|}
\hline No. & Gambar & Nama Latin & Nama Lokal & Jumlah & Satuan & Lokasi \\
\hline 2 & & $\begin{array}{l}\text { Cinnamomun } \\
\text { burmanii }\end{array}$ & Kayu manis & 20 & Pohon & $\begin{array}{l}\text { Tepi } \\
\text { jalan }\end{array}$ \\
\hline 3 & & $\begin{array}{l}\text { Erythrina crista } \\
\text { galli }\end{array}$ & Dadap merah & 2,0 & Pohon & $\begin{array}{l}\text { Tepi } \\
\text { jalan }\end{array}$ \\
\hline (C4) & & Ficus benjamina & Beringin & 4,0 & Pohon & $\begin{array}{l}\text { Tepi } \\
\text { jalan, } \\
\text { median }\end{array}$ \\
\hline$\hat{3}$ & & $\begin{array}{l}\text { Ficus elastica } \\
\text { 'Rubra' }\end{array}$ & Beringin karet & 1 & Pohon & Median \\
\hline $\begin{array}{l}\overline{\bar{c}} 6 \\
\overline{\overline{0}} \\
\bar{\omega}\end{array}$ & & $\begin{array}{l}\text { Muthingia } \\
\text { calabura }\end{array}$ & Kersen & 5,0 & Pohon & $\begin{array}{l}\text { Tepi } \\
\text { jalan }\end{array}$ \\
\hline 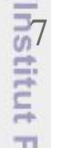 & & Sygyzium oleina & Pucuk merah & 82,0 & Pohon & $\begin{array}{l}\text { Tepi } \\
\text { jalan, } \\
\text { median }\end{array}$ \\
\hline 78 & & $\begin{array}{l}\text { Pterocarpus } \\
\text { indicus }\end{array}$ & Angsana & 33,0 & Pohon & Median \\
\hline 09 & & Stenolobiun stans & Tekoma & 3,0 & Pohon & Median \\
\hline 10 & & $\begin{array}{l}\text { Swietenia } \\
\text { mahogani }\end{array}$ & Mahoni & 34,0 & Pohon & $\begin{array}{l}\text { Tepi } \\
\text { jalan, } \\
\text { median }\end{array}$ \\
\hline 11 & & Veitchia merilii & Palem putri & 31,0 & Pohon & $\begin{array}{l}\text { Tepi } \\
\text { jalan }\end{array}$ \\
\hline Per & & & & & & \\
\hline 12 & & $\begin{array}{l}\text { Cordyline } \\
\text { terminalis } \\
\text { 'Rededge' }\end{array}$ & $\begin{array}{l}\text { Hanjuang } \\
\text { merah }\end{array}$ & 47,0 & $\mathrm{~m}^{2}$ & $\begin{array}{l}\text { Tepi } \\
\text { jalan }\end{array}$ \\
\hline$\frac{1}{6} 3$ & & Bougainvillea sp. & Bugenvil & 4,0 & $\mathrm{~m}^{2}$ & $\begin{array}{l}\text { Tepi } \\
\text { jalan }\end{array}$ \\
\hline 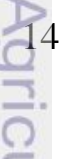 & & $\begin{array}{l}\text { Dracaena } \\
\text { marginata } \\
\text { 'Tricolor' }\end{array}$ & Drasena & 9,0 & $\mathrm{~m}^{2}$ & Median \\
\hline$\frac{9}{5}$ & & Heliconia sp. & Pisang hias & 9,0 & $\mathrm{~m}^{2}$ & $\begin{array}{l}\text { Tepi } \\
\text { jalan }\end{array}$ \\
\hline
\end{tabular}


Tabel 8 Vegetasi eksisting di jalur hijau Jalan Raya Pajajaran Segmen I (lanjutan)

\begin{tabular}{|c|c|c|c|c|c|c|}
\hline No. & Gambar & Nama Latin & Nama Lokal & Jumlah & Satuan & Lokas \\
\hline \multicolumn{7}{|c|}{ Semak } \\
\hline 16 & & $\begin{array}{l}\text { Oxmoxylon } \\
\text { lineare }\end{array}$ & $\begin{array}{l}\text { Aralia kaki } \\
\text { laba-laba }\end{array}$ & 5,5 & $\mathrm{~m}^{2}$ & $\begin{array}{l}\text { Tepi } \\
\text { jalan }\end{array}$ \\
\hline 17 & & $\begin{array}{l}\text { Acalypha } \\
\text { macrophilla }\end{array}$ & Teh-tehan & 50,6 & $\mathrm{~m}^{2}$ & $\begin{array}{l}\text { Tepi } \\
\text { jalan }\end{array}$ \\
\hline 18 & & Agave sp. & Agave & 4,0 & $\mathrm{~m}^{2}$ & $\begin{array}{l}\text { Pulau } \\
\text { jalan }\end{array}$ \\
\hline 19 & & Canna sp. & Kana & 2,1 & $\mathrm{~m}^{2}$ & $\begin{array}{l}\text { Tepi } \\
\text { jalan }\end{array}$ \\
\hline 20 & & Costus woodsonii & Pacing & 166,7 & $\mathrm{~m}^{2}$ & $\begin{array}{l}\text { Tepi } \\
\text { jalan }\end{array}$ \\
\hline 21 & & Crinum sp. & Bakung & 10,0 & $\mathrm{~m}^{2}$ & $\begin{array}{l}\text { Tepi } \\
\text { jalan }\end{array}$ \\
\hline 22 & & $\begin{array}{l}\text { Crossandra } \\
\text { infudibuliformis }\end{array}$ & Krosandra & 24,0 & $\mathrm{~m}^{2}$ & $\begin{array}{l}\text { Tepi } \\
\text { jalan }\end{array}$ \\
\hline 23 & & Dieffenbachia sp. & Daun bahagia & 12,6 & $\mathrm{~m}^{2}$ & $\begin{array}{l}\text { Tepi } \\
\text { jalan }\end{array}$ \\
\hline 24 & & $\begin{array}{l}\text { Euphorbia } \\
\text { trigonum }\end{array}$ & $\begin{array}{l}\text { Afican milk } \\
\text { tea }\end{array}$ & 4,0 & $\mathrm{~m}^{2}$ & $\begin{array}{l}\text { Tepi } \\
\text { jalan }\end{array}$ \\
\hline 25 & & $\begin{array}{l}\text { Excoecaria } \\
\text { cochinchinensis }\end{array}$ & Excoecaria & 3,0 & $\mathrm{~m}^{2}$ & $\begin{array}{l}\text { Pulau } \\
\text { jalan }\end{array}$ \\
\hline 36 & & $\begin{array}{l}\text { Hymenocallis } \\
\text { speciosa }\end{array}$ & Spider lily & 6,0 & $\mathrm{~m}^{2}$ & $\begin{array}{l}\text { Tepi } \\
\text { jalan }\end{array}$ \\
\hline 2 & & $\begin{array}{l}\text { Neomarica } \\
\text { longifolia }\end{array}$ & $\begin{array}{l}\text { Iris bunga } \\
\text { kuning }\end{array}$ & 30,0 & $\mathrm{~m}^{2}$ & $\begin{array}{l}\text { Tepi } \\
\text { jalan }\end{array}$ \\
\hline $\begin{array}{r}\text { Grou } \\
28\end{array}$ & & $\begin{array}{l}\text { Axonopus } \\
\text { compresus }\end{array}$ & Rumput & 200,0 & $\mathrm{~m}^{2}$ & Median \\
\hline 29 & $\frac{16}{3}$ & $\begin{array}{l}\text { Chlorophytum } \\
\text { laxum }\end{array}$ & $\begin{array}{l}\text { Lili paris } \\
\text { variegata }\end{array}$ & 18,0 & $\mathrm{~m}^{2}$ & Median \\
\hline
\end{tabular}


Tabel 8 Vegetasi eksisting di jalur hijau Jalan Raya Pajajaran Segmen I (lanjutan)

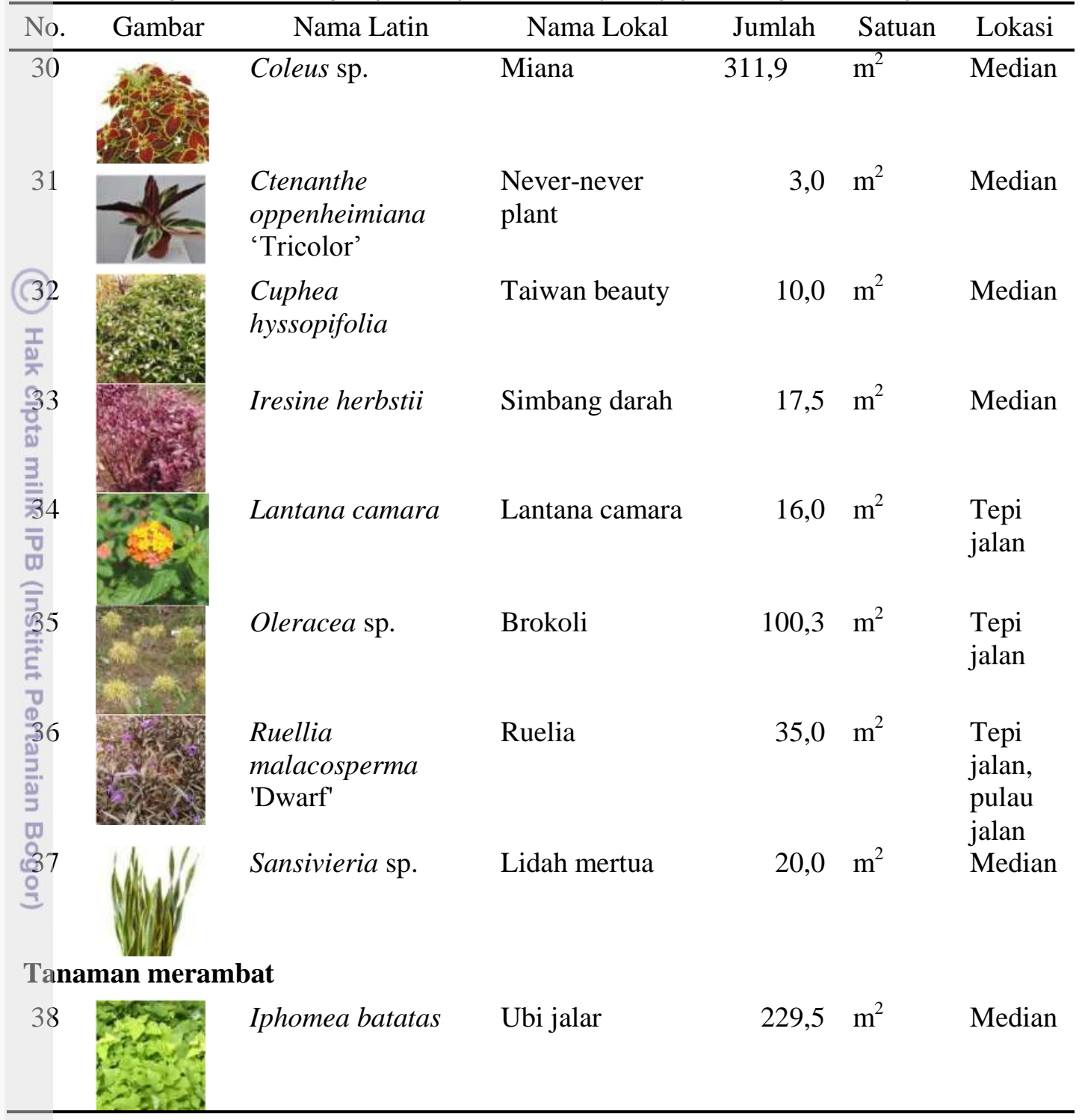

Jenis vegetasi di jalur hijau Jalan Raya Pajajaran Segmen II terdiri dari 15 jenis pohon, 5 jenis perdu, 4 jenis semak, dan 9 jenis ground cover. Tanaman yang mendominasi adalah jenis pohon (Tabel 9). Tidak terdapat satwa liar pada tapak.

(đabel 9 Vegetasi eksisting di jalur hijau Jalan Raya Pajajaran Segmen II

\begin{tabular}{|c|c|c|c|c|c|c|}
\hline No. & Gambar & Nama Latin & Nama Lokal & Jumlah & Satuan & Lokasi \\
\hline \multicolumn{7}{|c|}{ Pohon } \\
\hline$\frac{0}{2}$ & & $\begin{array}{l}\text { Adenanthera } \\
\text { pavonia }\end{array}$ & Saga & 3,0 & Pohon & Median \\
\hline 2 & & Bauhinia purpurea & $\begin{array}{l}\text { Bunga kupu- } \\
\text { kupu }\end{array}$ & 3,0 & Pohon & Median \\
\hline
\end{tabular}


Tabel 9 Vegetasi eksisting di jalur hijau Jalan Raya Pajajaran Segmen II (lanjutan)

\begin{tabular}{|c|c|c|c|c|c|c|}
\hline No. & Gambar & Nama Latin & Nama Lokal & Jumlah & Satuan & Lokasi \\
\hline 3 & & Ceiba petandra & Kapuk & 4,0 & Pohon & Median \\
\hline 4 & & Cerbera manghas & Bintaro & 6,0 & Pohon & Median \\
\hline 5 & & $\begin{array}{l}\text { Erythrina crista } \\
\text { galli }\end{array}$ & Dadap merah & 1,0 & Pohon & $\begin{array}{l}\text { Tepi } \\
\text { jalan }\end{array}$ \\
\hline 6 & & Ficus benjamina & Beringin & 4,0 & Pohon & $\begin{array}{l}\text { Tepi } \\
\text { jalan, } \\
\text { median }\end{array}$ \\
\hline 7 & & Laucaena glauca & Petai cina & 4,0 & Pohon & Median \\
\hline 8 & & $\begin{array}{l}\text { Muthingia } \\
\text { calabura }\end{array}$ & Kersen & 6,0 & Pohon & $\begin{array}{l}\text { Tepi } \\
\text { jalan }\end{array}$ \\
\hline 9 & & Sygyzium oleina & Pucuk merah & 279,0 & Pohon & $\begin{array}{l}\text { Median, } \\
\text { pulau } \\
\text { jalan }\end{array}$ \\
\hline 10 & & $\begin{array}{l}\text { Poisonus manihot } \\
\text { esulenta }\end{array}$ & $\begin{array}{l}\text { Singkong } \\
\text { genderuwo }\end{array}$ & 4,0 & Pohon & Median \\
\hline 11 & & $\begin{array}{l}\text { Pterocarpus } \\
\text { indicus }\end{array}$ & Angsana & 10,0 & Pohon & Median \\
\hline 12 & & $\begin{array}{l}\text { Ptychosperma } \\
\text { macarthurii }\end{array}$ & Palem hijau & 19,0 & Pohon & $\begin{array}{l}\text { Tepi } \\
\text { jalan }\end{array}$ \\
\hline 13 & & $\begin{array}{l}\text { Swietenia } \\
\text { mahogani }\end{array}$ & Mahoni & 202,0 & Pohon & $\begin{array}{l}\text { Tepi } \\
\text { jalan, } \\
\text { median }\end{array}$ \\
\hline 14 & & Tectonia grandis & Jati & 1,0 & Pohon & Median \\
\hline 15 & & $\begin{array}{l}\text { Terminalia } \\
\text { catappa }\end{array}$ & Ketapang & 2,0 & Pohon & $\begin{array}{l}\text { Tepi } \\
\text { jalan }\end{array}$ \\
\hline \multicolumn{7}{|c|}{ Perdun } \\
\hline 16 & $\frac{42}{5}$ & $\begin{array}{l}\text { Cordyline } \\
\text { terminalis } \\
\text { 'Rededge' }\end{array}$ & Hanjuang merah & 23,5 & $\mathrm{~m}^{2}$ & $\begin{array}{l}\text { Tepi } \\
\text { jalan }\end{array}$ \\
\hline
\end{tabular}


Tabel 9 Vegetasi eksisting di jalur hijau Jalan Raya Pajajaran Segmen II (lanjutan)

\begin{tabular}{|c|c|c|c|c|c|c|}
\hline No. & Gambar & Nama Latin & Nama Lokal & Jumlah & Satuan & Lokasi \\
\hline 17 & & $\begin{array}{l}\text { Dracaena } \\
\text { marginata } \\
\text { 'Tricolor' }\end{array}$ & Drasena & 22,0 & $\mathrm{~m}^{2}$ & Median \\
\hline 18 & & Heliconia sp. & Pisang hias & 20,0 & $\mathrm{~m}^{2}$ & $\begin{array}{l}\text { Tepi } \\
\text { jalan }\end{array}$ \\
\hline (11) 9 & & $\begin{array}{l}\text { Oxmoxylum } \\
\text { lineare }\end{array}$ & $\begin{array}{l}\text { Aralia kaki laba- } \\
\text { laba }\end{array}$ & 6,4 & $\mathrm{~m}^{2}$ & $\begin{array}{l}\text { Tepi } \\
\text { jalan }\end{array}$ \\
\hline$\frac{2}{0}$ & & Pachystachys lutea & Lolipop & 183,2 & $\mathrm{~m}^{2}$ & $\begin{array}{l}\text { Tepi } \\
\text { jalan }\end{array}$ \\
\hline S̈em & & & & & & \\
\hline$\frac{\overline{\overline{2}} 1}{\overline{\bar{z}}}$ & & $\begin{array}{l}\text { Acalypha } \\
\text { macrophilla }\end{array}$ & Teh-tehan & 25,3 & $\mathrm{~m}^{2}$ & $\begin{array}{l}\text { Tepi } \\
\text { jalan }\end{array}$ \\
\hline$\frac{2}{2} 2$ & & Canna sp. & Kana & 13,0 & $\mathrm{~m}^{2}$ & $\begin{array}{l}\text { Tepi } \\
\text { jalan }\end{array}$ \\
\hline 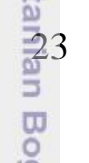 & & $\begin{array}{l}\text { Hymenocallis } \\
\text { speciosa }\end{array}$ & Spider lily & 90,0 & $\mathrm{~m}^{2}$ & $\begin{array}{l}\text { Tepi } \\
\text { jalan, } \\
\text { median }\end{array}$ \\
\hline 24 & & $\begin{array}{l}\text { Neomarica } \\
\text { longifolia }\end{array}$ & $\begin{array}{l}\text { Iris bunga } \\
\text { kuning }\end{array}$ & 30,0 & $\mathrm{~m}^{2}$ & $\begin{array}{l}\text { Tepi } \\
\text { jalan }\end{array}$ \\
\hline \multicolumn{7}{|c|}{ Ground cover } \\
\hline 26 & & $\begin{array}{l}\text { Aechmea } \\
\text { victoriana-discolor } \\
\text { x racinae }\end{array}$ & Bromelia & 9,0 & $\mathrm{~m}^{2}$ & Median \\
\hline 27 & & Aglaonema sp. & Sri Rejeki & 0,5 & $\mathrm{~m}^{2}$ & $\begin{array}{l}\text { Tepi } \\
\text { jalan }\end{array}$ \\
\hline $\begin{array}{l}028 \\
0\end{array}$ & & $\begin{array}{l}\text { Axonopus } \\
\text { compressus }\end{array}$ & Rumput & 1000,0 & $\mathrm{~m}^{2}$ & Median \\
\hline-29 & & Dianella zerumbet & Dianela & 25,0 & $\mathrm{~m}^{2}$ & Median \\
\hline $\begin{array}{l}\overline{3}^{30} \\
\frac{C^{\circ}}{E}\end{array}$ & & Oleracea sp. & Brokoli & 100,0 & $\mathrm{~m}^{2}$ & $\begin{array}{l}\text { Tepi } \\
\text { jalan }\end{array}$ \\
\hline
\end{tabular}


Tabel 9 Vegetasi eksisting di jalur hijau Jalan Raya Pajajaran Segmen II (lanjutan)

\begin{tabular}{lrlrrrr}
\hline No. & Gambar & \multicolumn{1}{c}{ Nama Latin } & Nama Lokal & Jumlah & Satuan & Lokasi \\
\hline 31 & $\begin{array}{l}\text { Ophiopogon } \\
\text { japanicus 'Kyoto } \\
\text { Dwarf' }\end{array}$ & Kucai & 23,0 & $\mathrm{~m}^{2}$ & Median \\
32 & $\begin{array}{l}\text { Sansivieria } \text { sp. } \\
33\end{array}$ & Lidah mertua & 60,0 & $\mathrm{~m}^{2}$ & Median \\
& $\begin{array}{l}\text { Zephyranthes } \\
\text { grandifola }\end{array}$ & Bawang brojol & 8,0 & $\mathrm{~m}^{2}$ & Median \\
\hline
\end{tabular}

Jenis vegetasi di jalur hijau Jalan Raya Pajajaran Segmen III terdiri dari 12 jenis p̄ohon, 9 jenis perdu, 5 jenis semak, 10 jenis ground cover, dan 1 jenis tanaman merambat. Jenis tanaman yang mendominasi adalah ground cover (Tabel 10). Tidak terdapat satwa liar pada tapak.

Tabel $\widehat{\overline{\bar{f}} 0}$ Vegetasi eksisting di jalur hijau Jalan Raya Pajajaran Segmen III

\begin{tabular}{|c|c|c|c|c|c|c|}
\hline No. & Gambar & Nama Latin & Nama Lokal & Jumlah & Satuan & Lokasi \\
\hline \multicolumn{7}{|c|}{ Pohonv } \\
\hline 1 & & $\begin{array}{l}\text { Adenanthera } \\
\text { pavonia }\end{array}$ & Saga & 2,0 & Pohon & Median \\
\hline 2 & & Bauhinia purpurea & $\begin{array}{l}\text { Bunga kupu- } \\
\text { kupu }\end{array}$ & 3,0 & Pohon & Median \\
\hline 3 & & Cerbera manghas & Bintaro & 1,0 & Pohon & Median \\
\hline 4 & & $\begin{array}{l}\text { Cinnamomun } \\
\text { burmanii }\end{array}$ & Kayu manis & 20,0 & Pohon & $\begin{array}{l}\text { Tepi } \\
\text { jalan }\end{array}$ \\
\hline 5 & & $\begin{array}{l}\text { Cupressus } \\
\text { papuana }\end{array}$ & Cemara gembel & 4,0 & Pohon & $\begin{array}{l}\text { Tepi } \\
\text { jalan }\end{array}$ \\
\hline 6 & & $\begin{array}{l}\text { Erythrina crista } \\
\text { galli }\end{array}$ & Dadap merah & 1,0 & Pohon & $\begin{array}{l}\text { Tepi } \\
\text { jalan }\end{array}$ \\
\hline 7 & & Ficus benjamina & Beringin & 1,0 & Pohon & $\begin{array}{l}\text { Tepi } \\
\text { jalan, } \\
\text { median }\end{array}$ \\
\hline 8 & द & $\begin{array}{l}\text { Muthingia } \\
\text { calabura }\end{array}$ & Kersen & 1,0 & Pohon & $\begin{array}{l}\text { Tepi } \\
\text { jalan }\end{array}$ \\
\hline
\end{tabular}


Tabel 10 Vegetasi eksisting di jalur hijau Jalan Raya Pajajaran Segmen III (lanjutan)

\begin{tabular}{|c|c|c|c|c|c|c|}
\hline No. & Gambar & Nama Latin & Nama Lokal & Jumlah & Satuan & Lokasi \\
\hline 9 & & Sygyzium oleina & Pucuk merah & 278,0 & Pohon & $\begin{array}{l}\text { Median, } \\
\text { pulau } \\
\text { jalan }\end{array}$ \\
\hline 10 & & $\begin{array}{l}\text { Pterocarpus } \\
\text { indicus }\end{array}$ & Angsana & 7,0 & Pohon & Median \\
\hline (ㄱ) & & $\begin{array}{l}\text { Ptychosperma } \\
\text { macarthurii }\end{array}$ & Palem hijau & 5,0 & Pohon & $\begin{array}{l}\text { Median, } \\
\text { tepi } \\
\text { jalan }\end{array}$ \\
\hline $\begin{array}{l}\frac{1}{0} 2 \\
\frac{0}{2} \\
3 \\
3\end{array}$ & & $\begin{array}{l}\text { Swietenia } \\
\text { mahogani }\end{array}$ & Mahoni & 107,0 & Pohon & $\begin{array}{l}\text { Tepi } \\
\text { jalan, } \\
\text { median }\end{array}$ \\
\hline$\overline{\bar{P}}$ er & & & & & & \\
\hline$\overline{\mathrm{d}} 3$ & & $\begin{array}{l}\text { Alocasia } \\
\text { macrorrhiza }\end{array}$ & Alokasia & 1,75 & $\mathrm{~m}^{2}$ & $\begin{array}{l}\text { Tepi } \\
\text { jalan }\end{array}$ \\
\hline$\underset{\partial}{\vec{\partial}} 4$ & & $\begin{array}{l}\text { Codiaeum } \\
\text { variegatum }\end{array}$ & Puring & 5,4 & $\mathrm{~m}^{2}$ & $\begin{array}{l}\text { Tepi } \\
\text { jalan }\end{array}$ \\
\hline$\frac{3}{3} 5$ & & $\begin{array}{l}\text { Cordyline } \\
\text { 'Bangkok rainbow' }\end{array}$ & Hanjuang & 1,0 & $\mathrm{~m}^{2}$ & $\begin{array}{l}\text { Tepi } \\
\text { jalan }\end{array}$ \\
\hline 196 & & Cordyline 'Stricta' & Hanjuang & 12,0 & $\mathrm{~m}^{2}$ & $\begin{array}{l}\text { Tepi } \\
\text { jalan }\end{array}$ \\
\hline 17 & & $\begin{array}{l}\text { Cordyline } \\
\text { terminalis } \\
\text { 'Rededge' }\end{array}$ & Hanjuang merah & 23,5 & $\mathrm{~m}^{2}$ & $\begin{array}{l}\text { Tepi } \\
\text { jalan }\end{array}$ \\
\hline 18 & & Dracaena laureiri & Drasena & 3,5 & $\mathrm{~m}^{2}$ & Median \\
\hline $\begin{array}{l}19 \\
0 \\
0\end{array}$ & & Heliconia sp. & Pisang hias & 20,0 & $\mathrm{~m}^{2}$ & $\begin{array}{l}\text { Tepi } \\
\text { jalan, } \\
\text { median }\end{array}$ \\
\hline 20 & & $\begin{array}{l}\text { Oxmoxylum } \\
\text { lineare }\end{array}$ & $\begin{array}{l}\text { Aralia kaki laba- } \\
\text { laba }\end{array}$ & 5,5 & $\mathrm{~m}^{2}$ & $\begin{array}{l}\text { Tepi } \\
\text { jalan }\end{array}$ \\
\hline$\frac{21}{\frac{2}{2}}$. & & Pachystachys lutea & Lolipop & 183,2 & $\mathrm{~m}^{2}$ & $\begin{array}{l}\text { Tepi } \\
\text { jalan }\end{array}$ \\
\hline
\end{tabular}


Tabel 10 Vegetasi eksisting di jalur hijau Jalan Raya Pajajaran Segmen III (lanjutan)

\begin{tabular}{|c|c|c|c|c|c|c|}
\hline No. & Gambar & Nama Latin & Nama Lokal & Jumlah & Satuan & Lokasi \\
\hline \multicolumn{7}{|c|}{ Semak } \\
\hline 22 & genses: & $\begin{array}{l}\text { Acalypha } \\
\text { macrophilla }\end{array}$ & Teh-tehan & 18,3 & $\mathrm{~m}^{2}$ & $\begin{array}{l}\text { Tepi } \\
\text { jalan }\end{array}$ \\
\hline 23 & & Canna sp. & Kana & 26,6 & $\mathrm{~m}^{2}$ & $\begin{array}{l}\text { Tepi } \\
\text { jalan, } \\
\text { median }\end{array}$ \\
\hline 24 & & $\begin{array}{l}\text { Hymenocallis } \\
\text { speciosa }\end{array}$ & Spider lily & 130,0 & $\mathrm{~m}^{2}$ & $\begin{array}{l}\text { Tepi } \\
\text { jalan, } \\
\text { median }\end{array}$ \\
\hline 25 & 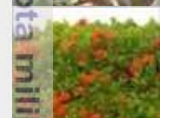 & Ixora sp. & Soka & 0,4 & $\mathrm{~m}^{2}$ & $\begin{array}{l}\text { Tepi } \\
\text { jalan }\end{array}$ \\
\hline 26 & $\begin{array}{l}\overline{0} \\
\overline{0} \\
\bar{z}\end{array}$ & $\begin{array}{l}\text { Neomarica } \\
\text { longifolia }\end{array}$ & $\begin{array}{l}\text { Iris bunga } \\
\text { kuning }\end{array}$ & 107,7 & $\mathrm{~m}^{2}$ & $\begin{array}{l}\text { Tepi } \\
\text { jalan }\end{array}$ \\
\hline \multicolumn{7}{|c|}{ Ground cover } \\
\hline 27 & & $\begin{array}{l}\text { Axonopus } \\
\text { compressus }\end{array}$ & Rumput & 1000 & $\mathrm{~m}^{2}$ & $\begin{array}{l}\text { Median, } \\
\text { tepi } \\
\text { jalan }\end{array}$ \\
\hline 28 & & $\begin{array}{l}\text { Chlorophytum } \\
\text { laxum }\end{array}$ & $\begin{array}{l}\text { Lili paris } \\
\text { variegata }\end{array}$ & 17,7 & $\mathrm{~m}^{2}$ & Median \\
\hline 29 & & $\begin{array}{l}\text { Cuphea } \\
\text { hyssopifolia }\end{array}$ & Tauwan beauty & 150,0 & $\mathrm{~m}^{2}$ & $\begin{array}{l}\text { Tepi } \\
\text { jalan }\end{array}$ \\
\hline 30 & & Dianella serumbet & Dianela & 9,0 & $\mathrm{~m}^{2}$ & Median \\
\hline 31 & & Lantana camara & Lantana camara & 8,0 & $\mathrm{~m}^{2}$ & $\begin{array}{l}\text { Tepi } \\
\text { jalan }\end{array}$ \\
\hline 32 & & Oleacea sp. & Brokoli & 100,8 & $\mathrm{~m}^{2}$ & $\begin{array}{l}\text { Tepi } \\
\text { jalan }\end{array}$ \\
\hline 33 & s: & $\begin{array}{l}\text { Ophiopogon } \\
\text { japanicus 'Kyoto } \\
\text { Dwarf' }\end{array}$ & Kucai & 20,0 & $\mathrm{~m}^{2}$ & Median \\
\hline 34 & $\begin{array}{l}2.5 \\
\frac{2}{4}\end{array}$ & $\begin{array}{l}\text { Ruellia } \\
\text { malacosperma } \\
\text { 'Dwarf' }\end{array}$ & Ruelia & 35,0 & $\mathrm{~m}^{2}$ & Median \\
\hline
\end{tabular}


Tabel 10 Vegetasi eksisting di jalur hijau Jalan Raya Pajajaran Segmen III (lanjutan)

\begin{tabular}{|c|c|c|c|c|c|c|}
\hline No. & Gambar & Nama Latin & Nama Lokal & Jumlah & Satuan & Lokasi \\
\hline 35 & & Sansivieria sp. & Lidah mertua & 60,0 & $\mathrm{~m}^{2}$ & Median \\
\hline 36 & & $\begin{array}{l}\text { Zephyranthes } \\
\text { grandifolia }\end{array}$ & Bawang brojol & 17,0 & $\mathrm{~m}^{2}$ & Median \\
\hline \multicolumn{7}{|c|}{ (Tanaman merambat } \\
\hline$\frac{37}{2}$ & & Philodendron sp. & Daun philo & 22,0 & $\mathrm{~m}^{2}$ & $\begin{array}{l}\text { Tepi } \\
\text { jalan }\end{array}$ \\
\hline
\end{tabular}

Jenis vegetasi di tepi Jalan Otto Iskandardinata didominasi oleh pohon. Jenis vegetasi di tapak terdiri dari 3 jenis pohon, 1 jenis perdu. 1 jenis semak, dan $\overline{\overline{2}}$ jenis ground cover (Tabel 11). Tidak terdapat satwa liar pada tapak.

京 abel 11 Vegetasi eksisting di jalur hijau Jalan Otto Iskandardinata

\begin{tabular}{|c|c|c|c|c|c|c|}
\hline N̦o. & Gambar & Nama Latin & Nama Lokal & Jumlah & Satuan & Lokasi \\
\hline \multicolumn{7}{|c|}{ Pohon } \\
\hline 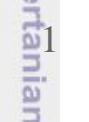 & & $\begin{array}{l}\text { Araucaria } \\
\text { heterophylla }\end{array}$ & Cemara norflok & 11,0 & Pohon & $\begin{array}{l}\text { Tepi } \\
\text { jalan }\end{array}$ \\
\hline $\begin{array}{l}\stackrel{2}{2} \\
\stackrel{0}{\Omega}\end{array}$ & & Elais gunensis & Kelapa sawit & 9,0 & Pohon & $\begin{array}{l}\text { Tepi } \\
\text { jalan }\end{array}$ \\
\hline 3 & & Roystonia regia & Palem raja & 10,0 & Pohon & $\begin{array}{l}\text { Tepi } \\
\text { jalan }\end{array}$ \\
\hline \multicolumn{7}{|c|}{ Perdu } \\
\hline 4 & & $\begin{array}{l}\text { Dracaena } \\
\text { deremensi 'Janet } \\
\text { Craig' }\end{array}$ & Kayu besi & 1,7 & $\mathrm{~m}^{2}$ & $\begin{array}{l}\text { Tepi } \\
\text { jalan }\end{array}$ \\
\hline \multicolumn{7}{|c|}{ Semak } \\
\hline $\begin{array}{l}05 \\
\frac{6}{0} \\
\frac{6}{6} \\
\text { Gro }\end{array}$ & 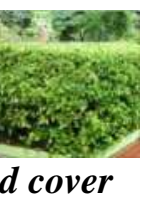 & $\begin{array}{l}\text { Acalypha } \\
\text { macrophilla }\end{array}$ & Teh-tehan & 3,5 & $\mathrm{~m}^{2}$ & $\begin{array}{l}\text { Tepi } \\
\text { jalan }\end{array}$ \\
\hline$\frac{0_{6}}{\bar{n}}$. & & Althenantera sp. & Krokot & 2,0 & $\mathrm{~m}^{2}$ & $\begin{array}{l}\text { Tepi } \\
\text { jalan }\end{array}$ \\
\hline $\begin{array}{l}\frac{E}{7} \\
\frac{E}{3}\end{array}$ & 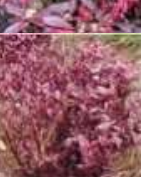 & Iresine herbstii & Simbang darah & 2,0 & $\mathrm{~m}^{2}$ & $\begin{array}{l}\text { Tepi } \\
\text { jalan }\end{array}$ \\
\hline
\end{tabular}


Jenis vegetasi di median Tol Jagorawi terdiri dari 4 jenis pohon, 2 jenis perdu, 2 jenis semak, 2 jenis ground cover dan 1 jenis tanaman merambat. Vegetasi eksisting di median Tol Jagorawi disajikan pada Tabel 12. Tidak terdapat satwa liar pada tapak.

Tabel 12 Vegetasi eksisting di median Tol Jagorawi

\begin{tabular}{|c|c|c|c|c|c|c|}
\hline No. & Gambar & Nama Latin & Nama Lokal & Jumlah & Satuan & Lokasi \\
\hline \multicolumn{7}{|c|}{ Pohon } \\
\hline 1 & & Phoenix roebelenii & $\begin{array}{l}\text { Phoenix daun } \\
\text { halus }\end{array}$ & 6,0 & Pohon & Median \\
\hline 2 & & $\begin{array}{l}\text { Tabebuia } \\
\text { chrysanta }\end{array}$ & $\begin{array}{l}\text { Tabebuya bunga } \\
\text { kuning }\end{array}$ & 34,0 & Pohon & Median \\
\hline 3 & & $\begin{array}{l}\text { Ptychosperma } \\
\text { macarthurii }\end{array}$ & Palem hijau & 29,0 & Pohon & Median \\
\hline 4 & & Veitchia merilii & Palem putri & 6,0 & Pohon & Median \\
\hline \multicolumn{7}{|c|}{ Perdu } \\
\hline 5 & & Bougainvilllea sp. & Bugenvil & 16,0 & $\mathrm{~m}^{2}$ & Median \\
\hline 6 & & $\begin{array}{l}\text { Oxmoxylum } \\
\text { lineare }\end{array}$ & $\begin{array}{l}\text { Aralia kaki laba- } \\
\text { laba }\end{array}$ & 109,0 & $\mathrm{~m}^{2}$ & Median \\
\hline \multicolumn{7}{|c|}{ Semak } \\
\hline 7 & & Agave sp. & Agave & 4,0 & $\mathrm{~m}^{2}$ & Median \\
\hline 8 & & Canna sp. & Kana & 150,0 & $\mathrm{~m}^{2}$ & Median \\
\hline \multicolumn{7}{|c|}{ Ground cover } \\
\hline 9 & & $\begin{array}{l}\text { Cuphea } \\
\text { hyssopifolia }\end{array}$ & Taiwan beauty & 90,0 & $\mathrm{~m}^{2}$ & Median \\
\hline 10 & & $\begin{array}{l}\text { Axonopus } \\
\text { compressus }\end{array}$ & Rumput & 1500,0 & $\mathrm{~m}^{2}$ & Median \\
\hline \multicolumn{7}{|c|}{ Tanaman merambat } \\
\hline 11 & 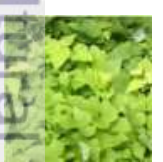 & Iphomea batatas & Ubi jalar & 124.02 & $\mathrm{~m}^{2}$ & Median \\
\hline
\end{tabular}


Jenis vegetasi di jalur hijau jalan di Jalan Bina Marga terdiri dari 14 jenis pohon, 4 jenis perdu, 5 jenis semak, dan 5 jenis ground cover (Tabel 13). Jenis pohon yang mendominasi adalah kayu manis (Cinnamomun burmanii). Satwa yang terdapat pada tapak adalah kupu-kupu.

Tabel 13 Vegetasi eksisting di jalur hijau Jalan Bina Marga

\begin{tabular}{|c|c|c|c|c|c|c|}
\hline No. & Gambar & Nama Latin & Nama Lokal & Jumlah & Satuan & Lokasi \\
\hline \multicolumn{7}{|c|}{ Pohon } \\
\hline (1) & & Agathis dammara & Damar & 2,0 & Pohon & $\begin{array}{l}\text { Tepi } \\
\text { jalan }\end{array}$ \\
\hline$\frac{92}{\frac{9}{2}}$ & & $\begin{array}{l}\text { Araucaria } \\
\text { heterophylla }\end{array}$ & Cemara norflok & 2,0 & Pohon & $\begin{array}{l}\text { Tepi } \\
\text { jalan }\end{array}$ \\
\hline$\frac{\overline{\bar{\lambda}}}{\overline{\bar{\sigma}}}$ & & Carica papaya & Pepaya & 1,0 & Pohon & $\begin{array}{l}\text { Tepi } \\
\text { jalan }\end{array}$ \\
\hline 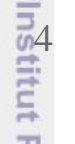 & & $\begin{array}{l}\text { Casuarina } \\
\text { sumatrana }\end{array}$ & Cemara sumatra & 1,0 & Pohon & $\begin{array}{l}\text { Tepi } \\
\text { jalan }\end{array}$ \\
\hline ב. & & $\begin{array}{l}\text { Cinnamomun } \\
\text { burmanii }\end{array}$ & Kayu manis & 12,0 & Pohon & $\begin{array}{l}\text { Taman } \\
\text { sudut }\end{array}$ \\
\hline 06 & & Cocos nucifera & Kelapa & 1,0 & Pohon & $\begin{array}{l}\text { Tepi } \\
\text { jalan }\end{array}$ \\
\hline 7 & & $\begin{array}{l}\text { Filicium decipirens } \\
\text { Thw. }\end{array}$ & Kere payung & 1,0 & Pohon & $\begin{array}{l}\text { Tepi } \\
\text { jalan }\end{array}$ \\
\hline 8 & & Musa acuminata & Pohon pisang & 5,0 & Pohon & $\begin{array}{l}\text { Tepi } \\
\text { jalan }\end{array}$ \\
\hline 9 & & Plumeria sp. & Kamboja & 4,0 & Pohon & $\begin{array}{l}\text { Taman } \\
\text { sudut }\end{array}$ \\
\hline do & & $\begin{array}{l}\text { Polyalthia } \\
\text { longifolia }\end{array}$ & Glodogan tiang & 1,0 & Pohon & $\begin{array}{l}\text { Tepi } \\
\text { jalan }\end{array}$ \\
\hline 11 & & $\begin{array}{l}\text { Pterocarpus } \\
\text { indicus }\end{array}$ & Angsana & 1,0 & Pohon & $\begin{array}{l}\text { Tepi } \\
\text { jalan }\end{array}$ \\
\hline$\overline{\mathrm{c}}^{\mathrm{a} 2}$ & & $\begin{array}{l}\text { Swietenia } \\
\text { mahogani }\end{array}$ & Mahoni & 5,0 & Pohon & $\begin{array}{l}\text { Tepi } \\
\text { jalan }\end{array}$ \\
\hline
\end{tabular}


Tabel 13 Vegetasi eksisting di jalur hijau Jalan Bina Marga (lanjutan)

\begin{tabular}{|c|c|c|c|c|c|c|}
\hline No. & Gambar & Nama Latin & Nama Lokal & Jumlah & Satuan & Lokasi \\
\hline 13 & & Veitchia merilii & Palem putri & 4,0 & Pohon & $\begin{array}{l}\text { Tepi } \\
\text { jalan }\end{array}$ \\
\hline 14 & & Wodyetia bifurcata & Palem ekor tupai & 1,0 & Pohon & $\begin{array}{l}\text { Taman } \\
\text { sudut }\end{array}$ \\
\hline \multicolumn{7}{|c|}{ Perdun } \\
\hline 15 & & $\begin{array}{l}\text { Alocasia } \\
\text { macrorrhiza }\end{array}$ & Alokasia & 3,5 & $\mathrm{~m}^{2}$ & $\begin{array}{l}\text { Tepi } \\
\text { jalan }\end{array}$ \\
\hline 16 & s. & Mussaenda sp. & Nusa indah & 2,0 & $\mathrm{~m}^{2}$ & $\begin{array}{l}\text { Tepi } \\
\text { jalan }\end{array}$ \\
\hline 17 & & $\begin{array}{l}\text { Cordyline } \\
\text { terminalis } \\
\text { 'Rededge' }\end{array}$ & Hanjuang merah & 0,3 & $\mathrm{~m}^{2}$ & $\begin{array}{l}\text { Tepi } \\
\text { jalan }\end{array}$ \\
\hline 18 & (6) & Dracaena laureiri & Drasena & 3,0 & $\mathrm{~m}^{2}$ & $\begin{array}{l}\text { Tepi } \\
\text { jalan }\end{array}$ \\
\hline \multicolumn{7}{|c|}{ Semak. } \\
\hline 19 & & $\begin{array}{l}\text { Oxmoxylum } \\
\text { lineare }\end{array}$ & $\begin{array}{l}\text { Aralia kaki laba- } \\
\text { laba }\end{array}$ & 3,0 & $\mathrm{~m}^{2}$ & $\begin{array}{l}\text { Tepi } \\
\text { jalan }\end{array}$ \\
\hline 20 & & $\begin{array}{l}\text { Acalypha } \\
\text { macrophilla }\end{array}$ & Teh-tehan & 0,9 & $\mathrm{~m}^{2}$ & $\begin{array}{l}\text { Tepi } \\
\text { jalan }\end{array}$ \\
\hline 21 & & Canna sp. & Kana & 1,7 & $\mathrm{~m}^{2}$ & \\
\hline 22 & & Ixora sp. & Soka & 10,0 & $\mathrm{~m}^{2}$ & $\begin{array}{l}\text { Tepi } \\
\text { jalan }\end{array}$ \\
\hline 23 & 8 & $\begin{array}{l}\text { Neomarica } \\
\text { longifolia }\end{array}$ & $\begin{array}{l}\text { Iris bunga } \\
\text { kuning }\end{array}$ & 17,0 & $\mathrm{~m}^{2}$ & $\begin{array}{l}\text { Taman } \\
\text { sudut }\end{array}$ \\
\hline \multicolumn{7}{|c|}{ Ground cover } \\
\hline 24 & & Arachis pintoi & $\begin{array}{l}\text { Kacang- } \\
\text { kacangan }\end{array}$ & 0,7 & $\mathrm{~m}^{2}$ & $\begin{array}{l}\text { Taman } \\
\text { sudut }\end{array}$ \\
\hline 25 & - 504 & Iresine herbstii & Simbang darah & 2,0 & $\mathrm{~m}^{2}$ & $\begin{array}{l}\text { Taman } \\
\text { sudut }\end{array}$ \\
\hline
\end{tabular}


Tabel 13 Vegetasi eksisting di jalur hijau Jalan Bina Marga (lanjutan)

\begin{tabular}{|c|c|c|c|c|c|c|}
\hline No. & Gambar & Nama Latin & Nama Lokal & Jumlah & Satuan & Lokasi \\
\hline 26 & and & Rhoedis color & Adam hawa & 0,3 & $\mathrm{~m}^{2}$ & $\begin{array}{l}\text { Taman } \\
\text { sudut }\end{array}$ \\
\hline 27 & & $\begin{array}{l}\text { Cuphea } \\
\text { hyssopifolia }\end{array}$ & Taiwan beauty & 7,0 & $\mathrm{~m}^{2}$ & \\
\hline $\begin{array}{l}28 \\
\frac{I}{\frac{I}{\pi}}\end{array}$ & & Oleracea sp. & Brokoli & 6,5 & $\mathrm{~m}^{2}$ & $\begin{array}{l}\text { Taman } \\
\text { sudut }\end{array}$ \\
\hline
\end{tabular}

Jenis vegetasi di tepi jalan di Jalan Padi terdiri dari 8 jenis pohon, 1 jenis perdu, 1 jenis semak, dan 3 jenis ground cover (Tabel 14). Jenis pohon yang mendominasi adalah bintaro (Cerbera manghas). Berdasarkan pengamatan Fapang, tidak terdapat satwa liar pada tapak.

信abel 14 Vegetasi eksisting di jalur hijau Jalan Padi

\begin{tabular}{|c|c|c|c|c|c|c|}
\hline Ño. & Gambar & Nama Latin & Nama Lokal & Jumlah & Satuan & Lokasi \\
\hline $\begin{array}{l}\text { Poh } \\
\text { ond }\end{array}$ & & Cerbera manghas & Bintaro & 12,0 & Pohon & $\begin{array}{l}\text { Tepi } \\
\text { jalan }\end{array}$ \\
\hline 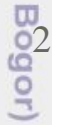 & & $\begin{array}{l}\text { Cinnamomun } \\
\text { burmanii }\end{array}$ & Kayu manis & 2,0 & Pohon & $\begin{array}{l}\text { Tepi } \\
\text { jalan }\end{array}$ \\
\hline 3 & & Ficus benjamina & Beringin & 2,0 & Pohon & $\begin{array}{l}\text { Tepi } \\
\text { jalan }\end{array}$ \\
\hline 4 & & Morinda citrifolia & Mengkudu & 1,0 & Pohon & $\begin{array}{l}\text { Tepi } \\
\text { jalan }\end{array}$ \\
\hline 5 & & $\begin{array}{l}\text { Muthingia } \\
\text { calabura }\end{array}$ & Kersen & 9,0 & Pohon & $\begin{array}{l}\text { Tepi } \\
\text { jalan }\end{array}$ \\
\hline 06 & & $\begin{array}{l}\text { Polyalthia } \\
\text { fragrans }\end{array}$ & Glodogan bulat & 1,0 & Pohon & $\begin{array}{l}\text { Tepi } \\
\text { jalan }\end{array}$ \\
\hline 7 & & Samanea saman & Ki hujan & 1,0 & Pohon & $\begin{array}{l}\text { Tepi } \\
\text { jalan }\end{array}$ \\
\hline$\stackrel{8}{=}$ & & $\begin{array}{l}\text { Swietenia } \\
\text { mahogani }\end{array}$ & Mahoni & 1,0 & Pohon & $\begin{array}{l}\text { Tepi } \\
\text { jalan }\end{array}$ \\
\hline
\end{tabular}


Tabel 14 Vegetasi eksisting di jalur hijau Jalan Padi (lanjutan)

\begin{tabular}{|c|c|c|c|c|c|c|}
\hline No. & Gambar & Nama Latin & Nama Lokal & Jumlah & Satuan & Lokasi \\
\hline \multicolumn{7}{|c|}{ Perdu } \\
\hline 9 & & $\begin{array}{l}\text { Codiaeum } \\
\text { variegatum }\end{array}$ & Puring & 0,4 & $\mathrm{~m}^{2}$ & $\begin{array}{l}\text { Tepi } \\
\text { jalan }\end{array}$ \\
\hline \multicolumn{7}{|c|}{ Semak } \\
\hline 10 & & Agave sp & Agave & 1,0 & $\mathrm{~m}^{2}$ & $\begin{array}{l}\text { Tepi } \\
\text { jalan }\end{array}$ \\
\hline \multicolumn{7}{|c|}{ Ground cover } \\
\hline 11 & & Aglaonema sp. & Sri Rejeki & 0,5 & $\mathrm{~m}^{2}$ & $\begin{array}{l}\text { Tepi } \\
\text { jalan }\end{array}$ \\
\hline 12 & & $\begin{array}{l}\text { Ophiopogon } \\
\text { japanicus 'Kyoto } \\
\text { Dwarf' }\end{array}$ & Kucai & 0,2 & $\mathrm{~m}^{2}$ & $\begin{array}{l}\text { Tepi } \\
\text { jalan }\end{array}$ \\
\hline 13 & & Sansivieria sp. & Lidah mertua & 1,0 & $\mathrm{~m}^{2}$ & $\begin{array}{l}\text { Tepi } \\
\text { jalan }\end{array}$ \\
\hline
\end{tabular}

Vegetasi yang mendominasi di jalur hijau Pakuan adalah jenis pohon. Secaravkeseluruhan, terdapat terdiri dari 7 jenis pohon, 1 jenis perdu, dan 3 jenis ground cover. Ground cover yang mendominasi adalah rumput (Axonopus compressus). Tidak terdapat satwa liar pada tapak. Jenis dan jumlah vegetasi di jalur hijau Jalan Pakuan disajikan pada Tabel 15.

Tabel 15 Vegetasi eksisting di jalur hijau Jalan Pakuan

\begin{tabular}{|c|c|c|c|c|c|c|}
\hline No. & Gambar & Nama Latin & Nama Lokal & Jumlah & Satuan & Lokasi \\
\hline \multicolumn{7}{|c|}{ Pohon } \\
\hline 1 & & Bauhinia purpurea & $\begin{array}{l}\text { Bunga kupu- } \\
\text { kupu }\end{array}$ & 1,0 & Pohon & Median \\
\hline 2 & & $\begin{array}{l}\text { Erythrina crista } \\
\text { galli }\end{array}$ & Dadap merah & 9,0 & Pohon & Median \\
\hline 3 & & Ficus benjamina & Beringin & 6,0 & Pohon & $\begin{array}{l}\text { Tepi } \\
\text { jalan, } \\
\text { median }\end{array}$ \\
\hline 4 & & $\begin{array}{l}\text { Pterocarpus } \\
\text { indicus }\end{array}$ & Angsana & 6,0 & Pohon & Median \\
\hline 5 & & Roystonia regia & Palem raja & 9,0 & Pohon & Median \\
\hline
\end{tabular}


Tabel 15 Vegetasi eksisting di jalur hijau Jalan Pakuan (lanjutan)

\begin{tabular}{|c|c|c|c|c|c|c|}
\hline No. & Gambar & Nama Latin & Nama Lokal & Jumlah & Satuan & Lokasi \\
\hline 6 & & $\begin{array}{l}\text { Swietenia } \\
\text { mahogani }\end{array}$ & Mahoni & 40,0 & Pohon & $\begin{array}{l}\text { Tepi } \\
\text { jalan, } \\
\text { median }\end{array}$ \\
\hline 7 & & $\begin{array}{l}\text { Muthingia } \\
\text { calabura }\end{array}$ & Kersen & 1,0 & Pohon & $\begin{array}{l}\text { Tepi } \\
\text { jalan }\end{array}$ \\
\hline \multicolumn{7}{|c|}{ Perdu } \\
\hline$\frac{\frac{1}{2}}{\frac{2}{2}}$ & & $\begin{array}{l}\text { Dracaena } \\
\text { deremensi 'Janet } \\
\text { Craig' }\end{array}$ & Kayu besi & 3,0 & $\mathrm{~m}^{2}$ & Median \\
\hline $\begin{array}{l}3 \\
\bar{z} \\
\bar{z} \\
\bar{z}\end{array}$ & & $\begin{array}{l}\text { Axonopus } \\
\text { compressus }\end{array}$ & Rumput & 400,0 & $\mathrm{~m}^{2}$ & $\begin{array}{l}\text { Tepi } \\
\text { jalan }\end{array}$ \\
\hline 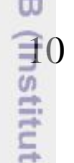 & 8 & $\begin{array}{l}\text { Ophiopogon } \\
\text { japanicus 'Kyoto } \\
\text { Dwarf' }\end{array}$ & Kucai & 1 & $\mathrm{~m}^{2}$ & $\begin{array}{l}\text { Tepi } \\
\text { jalan }\end{array}$ \\
\hline$\frac{91}{2}$ & 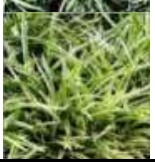 & $\begin{array}{l}\text { Chlorophytum } \\
\text { laxum }\end{array}$ & $\begin{array}{l}\text { Lili paris } \\
\text { variegata }\end{array}$ & 6,7 & $\mathrm{~m}^{2}$ & $\begin{array}{l}\text { Tepi } \\
\text { jalan }\end{array}$ \\
\hline
\end{tabular}

\section{Hardscape dan Site Structure}

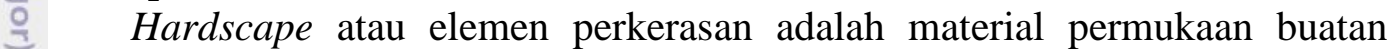
yang ditempatkan pada tanah di ruang terbuka, sedangkan site structure merupakan elemen konstruksi tiga dimensi (Booth 1983). Jenis dan jumlah site structure atau konstruksi tiga dimensi yang ada di setiap titik lokasi berbeda-beda. Secara keseluruhan, site structure yang terdapat dalam tapak adalah rambu dan marka jalan, signage, serta lampu penerangan jalan. Hardscape yang terdapat di Jalan Raya Pajajaran Segmen I terdiri dari aspal, kansteen, dan paving. Site structure yang terdapat di Jalan Raya Pajajajan Segmen I disajikan dalam Tabel 16.

Tabel 16 Site structure di Jalan Raya Pajajaran Segmen I

\begin{tabular}{|c|c|c|c|c|}
\hline (No. & Jenis Site Structure & Jumlah & Satuan & Lokasi \\
\hline$\frac{0}{6} 1$ & Rambu dan Marka jalan & 23 & Buah & $\begin{array}{l}\text { Tepi jalan, } \\
\text { median }\end{array}$ \\
\hline$\frac{2}{6}$ & Signage & 5 & Buah & $\begin{array}{l}\text { Tepi jalan, } \\
\text { median }\end{array}$ \\
\hline $\bar{\Omega}^{3}$ & Lampu penerangan jalan & 4 & Titik lampu & $\begin{array}{l}\text { Median, tepi } \\
\text { jalan }\end{array}$ \\
\hline${ }_{4}$ & $\begin{array}{l}\text { Jembatan penyeberangan orang } \\
\text { (JPO) }\end{array}$ & 1 & Unit & Tepi jalan \\
\hline$a^{5}$ & Halte & 1 & Unit & Tepi jalan \\
\hline
\end{tabular}


Tabel 16 Site structure di Jalan Raya Pajajaran Segmen I (lanjutan)

\begin{tabular}{clrll}
\hline No. & \multicolumn{1}{c}{ Jenis Site Structure } & Jumlah & Satuan & \multicolumn{1}{c}{ Lokasi } \\
\hline 6 & Planter box & 2 & Buah & Tepi jalan \\
7 & Pos DLLAJ & 1 & Unit & Tepi jalan \\
8 & Tempat sampah & 1 & Buah & Tepi jalan \\
9 & Pagar & 96 & m & Median \\
\hline
\end{tabular}

Hardscape yang terdapat di Jalan Raya Pajajaran Segmen I terdiri dari aspal, kansteen, dan paving. Site structure yang terdapat di Jalan Raya Pajajajan terdiri dari rambu dan marka jalan, signage, lampu penerangan jalan, planter box, bollar dan halte. Jumlah dari masing-masing site structure yang terdapat di Jalan Raya Rajajaran Segmen II disajikan dalam Tabel 17.

Tabel 17 Site structure di Jalan Raya Pajajaran Segmen II

\begin{tabular}{clrll}
\hline No. & \multicolumn{1}{c}{ Jenis Site Structure } & Jumlah & Satuan & \multicolumn{1}{c}{ Lokasi } \\
\hline 1 & Rambu dan marka jalan & 11 & Buah & Tepi jalan, \\
& median \\
2 & Signage & 14 & Buah & Tepi jalan \\
3 & Tampu penerangan jalan & 5 & Titik lampu & Median, tepi \\
& E & & & jalan \\
4 & Dlanter box & 2 & Buah & Median \\
5 & Bollard & 7 & Unit & Median \\
6 & Halte & 2 & Unit & Tepi jalan \\
\hline
\end{tabular}

Hardscape yang terdapat di Jalan Raya Pajajaran Segmen I terdiri dari aspal, qkansteen, dan paving. Drainase yang terdapat di tapak terdiri dari drainase terbuka dan tertutup. Site structure yang terdapat di Jalan Raya Pajajajan Segmen III terdiri dari rambu dan marka jalan, signage, lampu penerangan jalan, bollard, halte, dan tempat sampah (Tabel 18).

Tabel 18 Site structure di Jalan Raya Pajajaran Segmen III

\begin{tabular}{clrll}
\hline No. & \multicolumn{1}{c}{ Jenis Site Structure } & Jumlah & \multicolumn{1}{c}{ Satuan } & \multicolumn{1}{c}{ Lokasi } \\
\hline 1 & Rambu dan marka jalan & 11 & Buah & Tepi jalan, \\
& & & & median \\
2 & Signage & 14 & Buah & Tepi jalan \\
3 & Lampu penerangan jalan & 5 & Titik lampu & Median \\
4 & Bollard & 7 & Unit & Median \\
5 & Galte & 2 & Unit & Tepi jalan \\
6 & Tempat sampah & 1 & Buah & Tepi jalan \\
\hline
\end{tabular}

Hardscape yang terdapat di Jalan Otto Iskandardinata terdiri dari aspal, kansteen dan paving. Drainase yang terdapat di tapak adalah drainase terbuka. Jenis-jenis site structure yang terdapat di tapak terdiri dari rambu dan marka jalan, halte, bollard, serta lampu penerangan jalan (Tabel 19). 
Tabel 19 Site structure di Otto Iskandardinata

\begin{tabular}{clrll}
\hline No. & \multicolumn{1}{c}{ Jenis Site Structure } & Jumlah & \multicolumn{1}{c}{ Satuan } & Lokasi \\
\hline 1 & Rambu dan marka jalan & 6 & Buah & Tepi jalan \\
2 & Signage & 1 & Buah & Tepi jalan \\
3 & Lampu penerangan jalan & 1 & Titik lampu & Tepi jalan \\
\hline
\end{tabular}

Hardscape yang terdapat di Tol Jagorawi adalah aspal dan kansteen. Drainase yang terdapat di jalan tol adalah drainase terbuka. Site structure yang terdapat di tapak adalah lampu penerangan jalan serta rambu dan marka jalan (Tabel 20).

Tabel 20 Site structure di Tol Jagorawi

\begin{tabular}{llrll}
\hline No. & \multicolumn{1}{c}{ Jenis Site Structure } & Jumlah & \multicolumn{1}{c}{ Satuan } & \multicolumn{1}{c}{ Lokasi } \\
\hline 1 & Rambu dan marka jalan & 2 & Buah & Median \\
2 & Lampu penerangan jalan & 12 & Titik lampu & Median \\
\hline
\end{tabular}

Drainase di Jalan Bina Marga terdiri dari drainase terbuka dan tertutup. Elardscape yang terdapat di Jalan Bina Marga terdiri dari keramik, paving, Kansteen, dan aspal. Jenis site structure pada tapak tersaji pada Tabel 21.

尹abel 21 Site structure di Jalan Bina Marga

\begin{tabular}{llrll}
\hline No. & \multicolumn{1}{c}{ Jenis Site Structure } & Jumlah & Satuan & Lokasi \\
\hline 11 & Rambu dan marka jalan & 6 & Buah & Tepi jalan \\
& 15 & Titik lampu & Tepi jalan \\
2 & Lampu penerangan jalan & 2 & Buah & Tepi jalan \\
\hline
\end{tabular}

Drainase di Jalan Padi terdiri dari drainase terbuka dan tertutup. Hardscape yang terdapat di Jalan Padi terdiri dari paving, batu bata, kerikil, dan aspal. Site structure yang terdapat di tapak adalah lampu penerangan jalan serta rambu dan marka jalan (Tabel 22).

Tabel 22 Site structure di Jalan Padi

\begin{tabular}{rlrll}
\hline No. & \multicolumn{1}{c}{ Jenis Site Structure } & Jumlah & Satuan & Lokasi \\
\hline 1 & Rambu dan marka jalan & 3 & Buah & Tepi jalan \\
2 & Lampu penerangan jalan & 4 & Titik lampu & Tepi jalan \\
03 & Tempat sampah & 1 & Buah & Tepi jalan \\
\hline
\end{tabular}

Hardscape yang terdapat di Jalan Padi terdiri dari paving, kerikil, dan aspal dengan jenis drainase terbuka dan tertutup. Site structure yang terdapat di tapak adalah lampu penerangan jalan serta rambu dan marka jalan (Tabel 23).

Tabel 23 Site structure di Jalan Pakuan

\begin{tabular}{llrll}
\hline No. & \multicolumn{1}{c}{ Jenis Site Structure } & Jumlah & \multicolumn{1}{c}{ Satuan } & Lokasi \\
\hline 1 & Rambu dan marka jalan & 10 & Buah & Tepi jalan \\
& Lampu penerangan jalan & 4 & Titik lampu & Tepi jalan \\
\hline
\end{tabular}


Tabel 23 Site structure di Jalan Pakuan (lanjutan)

\begin{tabular}{clrll}
\hline No. & Jenis Site Structure & Jumlah & Satuan & Lokasi \\
\hline 3 & Tempat sampah & 3 & Buah & Tepi jalan \\
4 & Pagar & 18 & $\mathrm{~m}$ & Tepi jalan \\
\hline
\end{tabular}

\section{Aspek Sosial}

\section{Pengguna Jalan}

Pengguna jalan di Kelurahan Baranangsinag terdiri dari pejalan kaki (pedestrian) dan pengguna kendaraan bermotor (vehicular). Berdasarkan hasil pengamatan lapang, waktu yang padat dengan pengguna jalan di Jalan Raya Pajajẵan terjadi pada pukul 08.30--09.00 WIB, pukul 11.00-12.00, dan 16.30-18.00 WIB. Waktu yang padat dengan pengguna jalan di Jalan Padi dan Jalan Bina Marga terjadi pada pukul 07.00--08.00 WIB dan 16.30--18.00 WIB. Waktu yang padat dengan pengguna jalan di Jalan Pakuan terjadi pada pukul 12.00-13.00 WIB dan 16.30--18.00 WIB. Waktu yang padat dengan pengguna jalan di

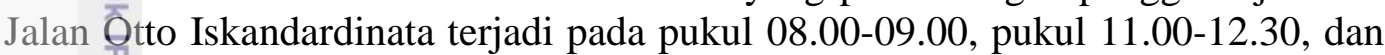
$16.30-18.00 \mathrm{WIB}$.

\section{Aspek Kegiatan Pengelolaan}

\section{¿Dinas Kebersihan dan Pertamanan Kota Bogor}

${ }_{0}$ Berdasarkan Dinas Kebersihan dan Pertamanan Kota Bogor memiliki tugas pokok menjalankan kegiatan di bidang kebersihan dan pertamanan. Fungsi Dinas Kebersihan dan Pertamanan adalah sebagai berikut:

1. perumusan kebijakan teknis di bidang kebersihan dan pertamanan;

2. penyelenggaraan urusan pemerintahan dan pelayanan umum di bidang okebersihan dan pertamanan;

3. pembinaan dan pelaksanaan tugas di bidang kebersihan dan pertamanan;

4. pelaksanaan tugas lain yang diberikan oleh walikota sesuai dengan tugas dan fungsinya.

\section{Visi dan misi}

Visi Dinas Kebersihan dan Pertamanan Kota Bogor mengacu kepada visi Kota Bogor, yaitu "terwujudnya Kota Bogor yang bersih dan indah dengan pelayanan prima". Untuk dapat mewujudkan visi yang telah disepakati, ditetapkan misi Dinas Kebersihan dan Pertamanan Kota Bogor, yaitu sebagai berikut:

1. meningkatkan pelayanan dalam bidang kebersihan, pertamanan, dan dekorasi kota untuk mewujudkan Kota Bogor yang bersih, indah, dan conyaman;

2. meningkatkan penataan, pemeliharaan dan penambahan ruang terbuka hijau (RTH) menuju Kota Bogor hijau lestari;

3. meningkatkan pengelolaan sarana dan prasarana tempat pembuangan sampah terpadu, pengolahan air limbah (IPAL), dan pemakaman umum 万untuk mendukung sanitasi lingkungan sehat;

4.-meningkatkan peran serta masyarakat dalam menjaga lingkungan sehat - dengan konsep 3R (reduse, re-use, recycle) atau mengurangi, memanfaatkan kembali, dan mendaur ulang sampah. 


\section{Tujuan}

Tujuan yang dirumuskan oleh Dinas Kebersihan dan Pertamanan mengacu kepada pernyataan visi dan misi, yaitu

1. menjadikan lingkungan bersih dan berkelanjutan;

2. mewujudkan Kota Bogor hijau lestari melalui penambahan, penataan, dan pemeliharaan taman sebagai bagian dari ruang terbuka hijau;

3. mewujudkan Kota Bogor yang bersih dengan lingkungan sehat melalui optimalisasi pengelolaan sarana dan prasarana;

4. menyediakan sarana prasarana pengelolaan sampah 3R yang memadai.

\section{Program}

Program adalah suatu kumpulan tindakan-tindakan konkret yang akan đilaksanakan. Program Dinas Kebersihan dan Pertamanan Kota Bogor merupakan penjabaran dari langkah-langkah yang diambil untuk menjabarkan kebijakan yang telah ditetapkan. Program-program Dinas Kebersihan dan Pertamanan Kota Bogor meliputi

1. program pengembangan kinerja pelayanan persampahan,

2. program pengelolaan $\mathrm{RTH}$,

3. program peningkatan utilitas perkotaan,

4. program pengembangan kinerja pengelolaan air minum dan limbah, dan

5. program pengelolaan areal pemakaman.

\section{Sasaran}

Sasaran yang dibuat mengacu pada program-program yang dibuat oleh Dinas Kebersihan dan Pertamanan, yaitu

1. meningkatnya kualitas sarana dan prasarana persampahan;

2. meningkatkan kualitas dan kuantitas taman kota dan taman lingkungan;

3. menata lokasi pedagang kaki lima (PKL);

4. meningkatnya penerangan kota, dengan indikasi kegiatan berupa

a. pembayaran rekening penerangan jalan umum (PJU);

b. pemeliharaan panel PJU, lampu PJU, dan lampu highmast;

c. pemeliharaan lampu taman dan lampu hias;

d. peningkatan kinerja pelayanan PJU;

e. pemasangan lampu highmast;

f. pemasangan lampu PJU di lingkungan permukiman;

g. pemasangan KWH meter;

h. pembuatan detail engineering design (DED) lampu taman;

5. meningkatnya kinerja pengelolaan air limbah (IPAL);

6. membangun dan menata areal pemakaman, dengan indikasi kegiatan berupa
a. pelayanan TPU;
b. penataan TPU;
c. pembuatan informasi pelayanan pemakaman.

\section{Strategi dan kebijakan}

Kebijakan merupakan pedoman atau petunjuk secara garis besar untuk pengambilan keputusan. Dinas Kebersihan dan Pertamanan menetapkan empat 
strategi pokok dalam upaya mewujudkan visi, menjalankan misi, serta mencapai tujuan dan sasaran:

1. strategi peningkatan kinerja pelayanan dan penambahan serta pemeliharaan prasarana pendukung;

2. strategi optimalisasi fungsi dan luas RTH;

3. strategi penambahan dan pemeliharaan sarana prasarana serta pengawasan dampak terhadap lingkungan;

4. strategi penentuan lokasi 3R dan sosialisasi/ pembinaan pengelolaan sampah skala lingkungan.

\section{Struktür organisasi}

तrganisasi Dinas Kebersihan dan Pertamanan (DKP), Kota Bogor, terdiri dari kepala dinas, sekretaris, bidang kebersihan, bidang penerangan jalan umum (PJU) dan dekorasi kota, bidang pertamanan, bidang pembinaan pengelolaan sampa , dan tiga unit pelaksana teknis dinas (UPTD). Struktur organisasi secara umum disajikan dalam Gambar 9.

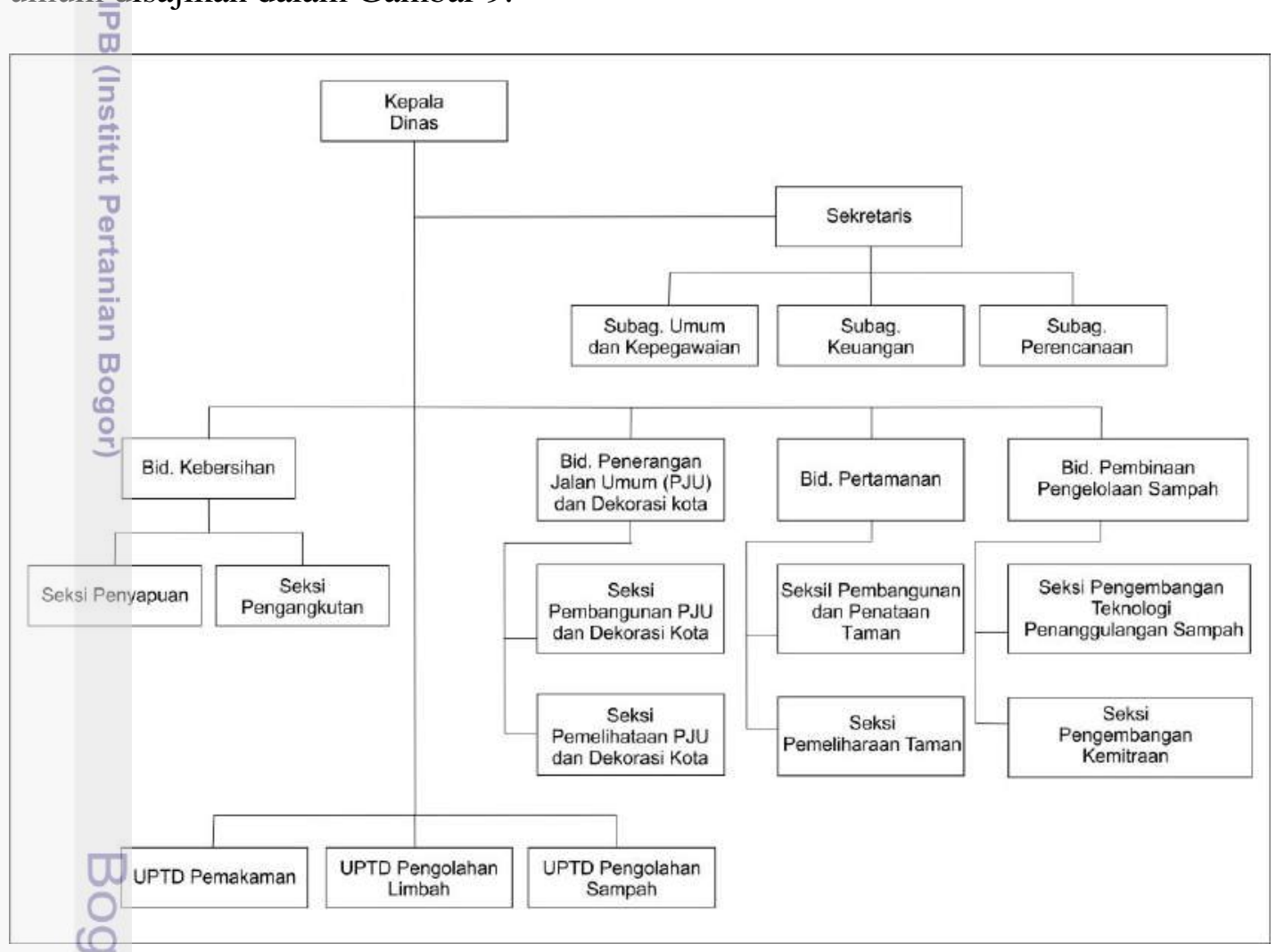

OGambar 9 Struktur organisasi Dinas Kebersihan dan Pertamanan (DKP) Sumber: Dinas Kebersihan dan Pertamanan

\section{Bidang Pertamanan}

Bidang pertamanan terdiri dari dua seksi, yaitu seksi pemeliharaan taman dan seksi pembangunan dan penataan taman. Pengelolaan jalur hijau jalan Kelurăan Baranangsiang menjadi tanggung jawab seksi pemeliharaan taman. 


\section{Struktur organisasi}

Kegiatan pengelolaan dan pemeliharaan RTH Kota Bogor dilakukan oleh Seksi Pemeliharaan Taman. Struktur organisasi Seksi Pemeliharaan Taman secara rinci disajikan pada Gambar 10.

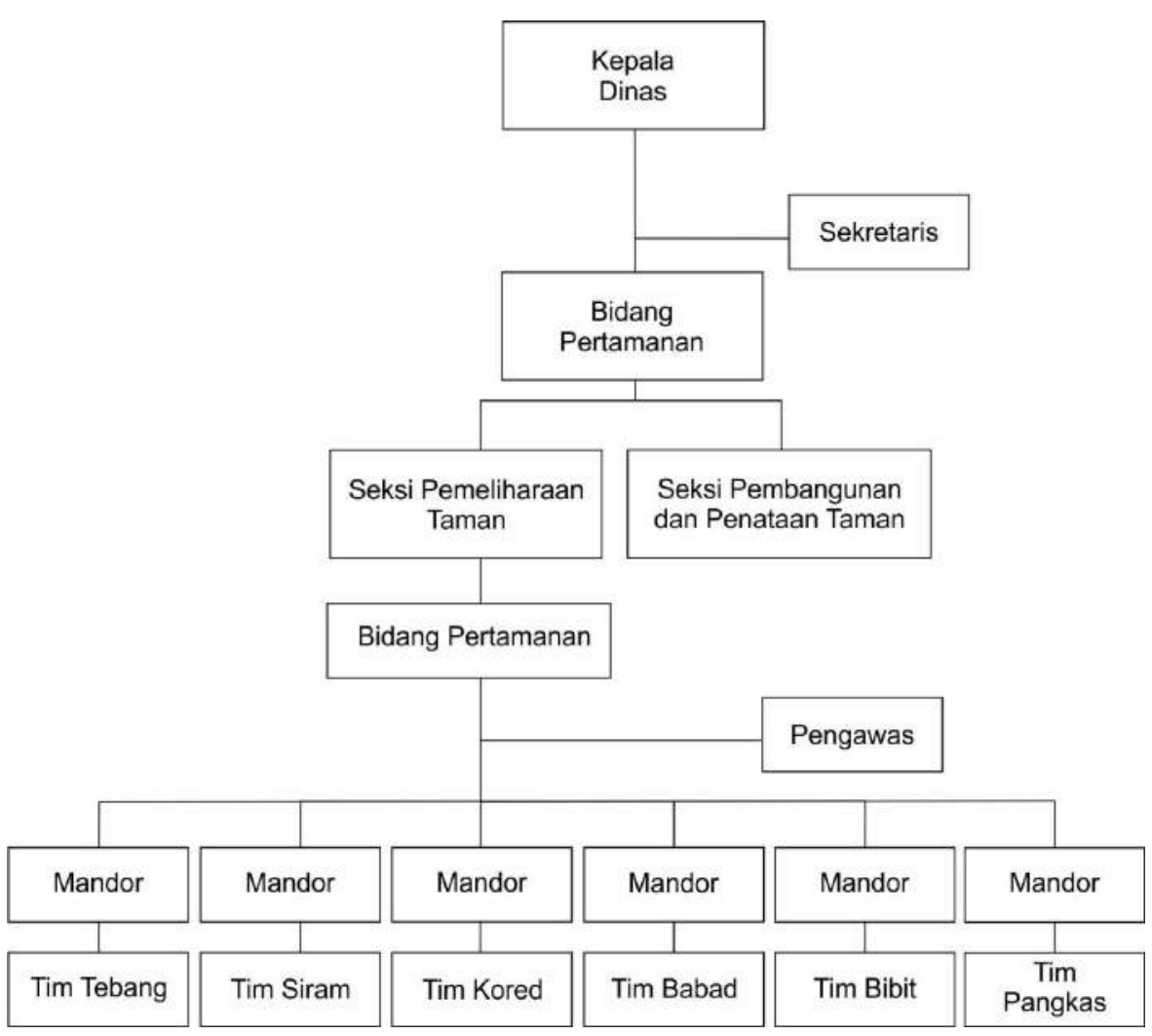

Gambar 10 Struktur organisasi Bidang Pertamanan Sumber: Bidang Pertamanan DKP

\section{Tenaga kerja}

Pekerja lapang dibagi menjadi beberapa tim berdasarkan tugasnya, yaitu tim tebang, tim siram, tim kored, tim pembibitan, tim pemangkasan pohon, dan tim babad rumput. Terdapat 1 tim tebang, 3 tim siram, 8 tim kored, 1 tim babad rumput, 1 tim pangkas, 1 tim bibit. Tim tebang bertugas untuk menebang pohon. Tim siram bertugas untuk melakukan penyiraman. Tim kored bertugas untuk melakukan kegiatan pemeliharaan taman. Tim babad bertugas untuk membabad rumput. Tim pangkas bertugas untuk memangkas ranting dan dahan pohon.

Jumlah pengawas kegiatan pemeliharaan secara keseluruhan sebanyak 9 Orang pengawas yang terdiri dari 8 pengawas wilayah dan 1 pengawas umum. Jumlah pengawas wilayah disesuaikan dengan jumlah tim kored. Salah satu (wilayah kerja dari tim kored DKP adalah di jalur hijau Kelurahan Baranangsiang. Jumlah personal dari tim kored di Kelurahan Baranangsiang terdiri atas 21 orang, yaitu 1 orang mandor dan 20 orang pekerja lapang.

Area kerja dari tim tebang, babad, pangkas, dan bibit adalah se-Kota Bogor, sedangkan area kerja tim kored dibagi berdasarkan luas area yang dipelihara. Kegiatan pemeliharaan harian di ruang terbuka yang dikelola oleh Dinas Kebersihan dan Pertamanan (DKP) dilaksanakan oleh tim kored. Kegiatan- 
kegiatan tersebut meliputi penyapuan dan pemangkasan rumput, penyiangan gulma, penyapuan perkerasan, pembuangan sampah, pemangkasan semak dan tanaman penutup tanah atau ground cover. Jalan Raya Pajajaran termasuk ke dalam 3 wilayah administrasi, yaitu Kecamatan Bogor Utara, Kecamatan Bogor Tengah, dan Kecamatan Bogor Timur. Jalur hijau di Jalan Raya Pajajaran yang dipelihara adalah jalur hijau yang berada di wilayah Bogor Timur.

Kegiatan penyiraman tidak termasuk dalam kegiatan pemeliharaan tim kored. Kegiatan penyiraman dilakukan oleh tim siram setiap hari pada pukul 08.00 oleh tim penyiraman dari Bidang Pertamanan, Dinas Kebersihan dan Pertamanan, Kota Bogor (Gambar 11).

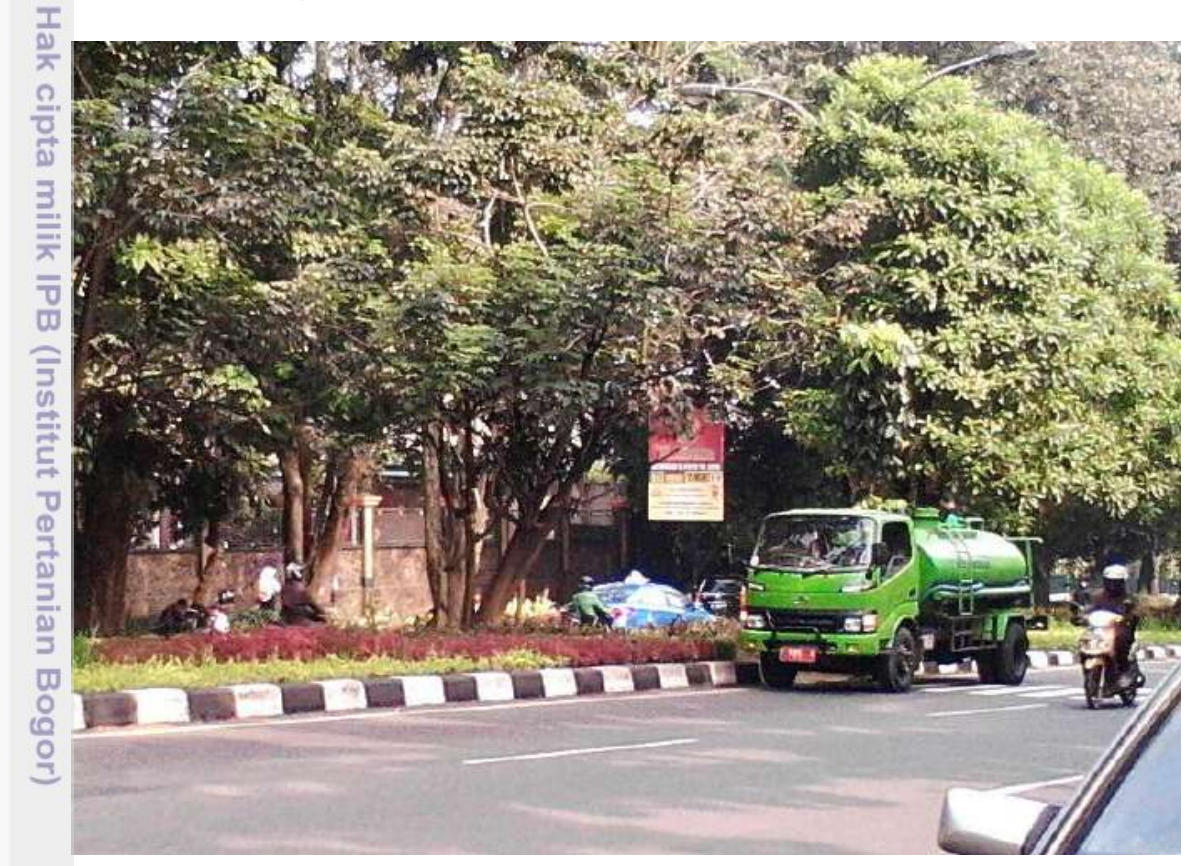

Gambar 11 Kegiatan penyiraman jalur hijau jalan Sumber: dokumentasi pribadi

\section{Jadwal kegiatan}

Jam kerja dimulai pukul 08.00 s.d. 14.00 dengan waktu istirahat satu jam (pukul 12.00 s.d. 13.00). Jumlah hari kerja sebanyak 6 hari kerja (hari Senin s.d. Sabtu). Kegiatan pemeliharaan dilakukan secara bersama-sama. Terkadang, mandor membagi tim menjadi dua. Frekuensi setiap kegiatan berbeda-beda. Frekuensi kegiatan pemeliharaan tersaji pada Tabel 24.

Tabel24 Frekuensi kegiatan pemeliharaan

\begin{tabular}{|c|c|c|}
\hline No. & Aktivitas & Frekuensi \\
\hline 17 & Penyapuan rumput & Harian \\
\hline $2 \Subset$ & Pemangkasan rumput & Bulanan \\
\hline $3=$ & Penyapuan perkerasan & Harian \\
\hline 4 & Pembuangan sampah & Harian \\
\hline 5 & Penyiangan gulma & Harian \\
\hline 5 & EPemangkasan semak dan ground cover & Bulanan \\
\hline 6 & Pemangkasan ranting dan dahan pohon & Semesteran \\
\hline
\end{tabular}

Sumber: Wawancara dan survei lapang 
Alat dan Bahan

Pengadaan alat dan bahan pengelolaan jalur hijau jalan menjadi tanggung jawab pihak Dinas Kebersihan dan Pertamanan. Saat ini, pengelolaan suku cadang dari peralatan telah menjadi tanggung jawab dari UPTD Peralatan dan Perbengkelan, Kota Bogor. Peralatan yang diperlukan dalam kegiatan pemeliharaan tersaji dalam Tabel 25.

Tabel 25 Peralatan pemeliharaan

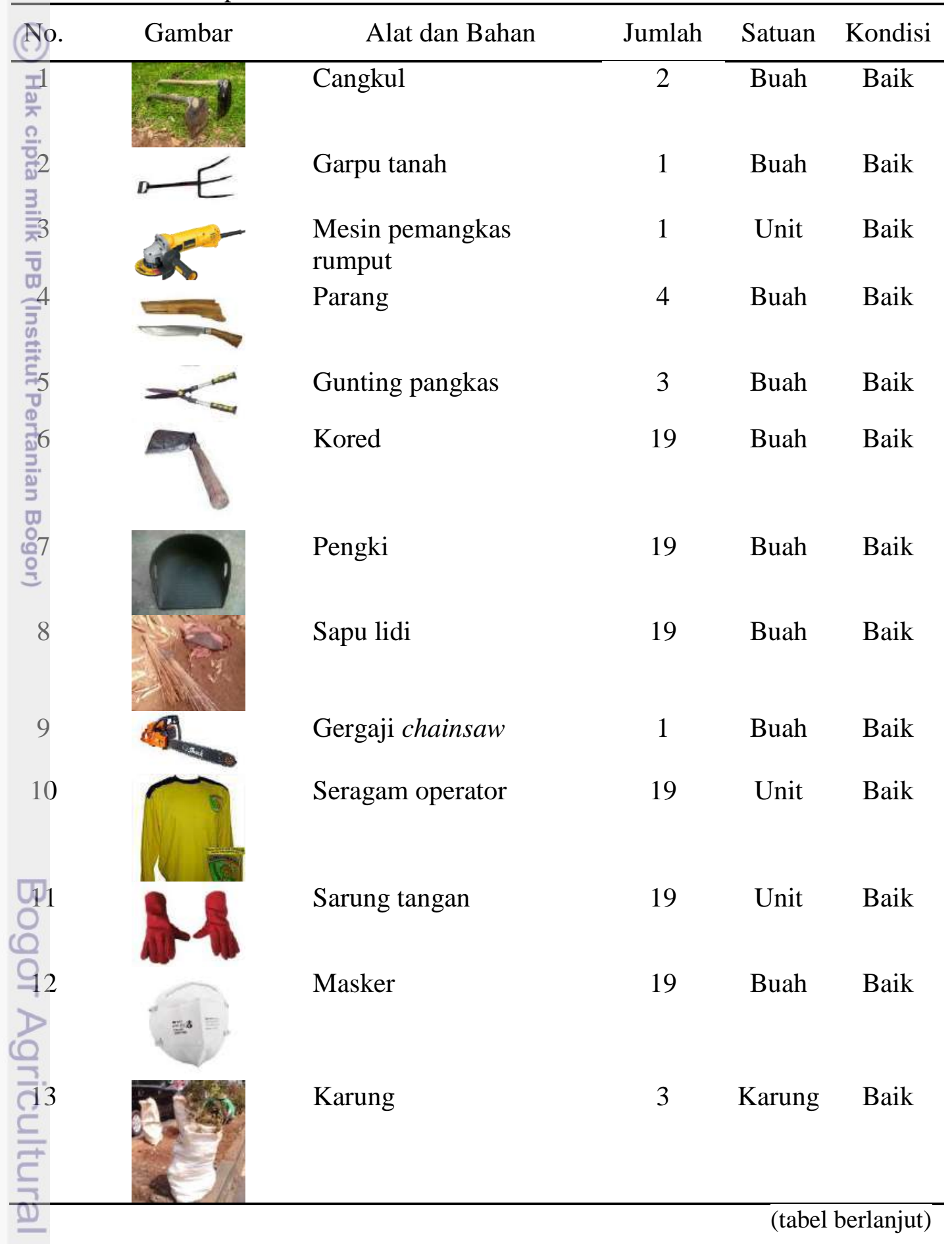


Tabel 25 Peralatan pemeliharaan (lanjutan)

\begin{tabular}{l|ccccc}
\hline No. & Gambar & Alat dan Bahan & Jumlah & Satuan & Kondisi \\
\hline 14 & & Motor sampah & & Unit & Baik \\
& & & & & \\
\hline & & & & & \\
\hline
\end{tabular}

Bahan yang digunakan dalam pengelolaan adalah bahan bakar bensin untuk Tmengoperasikan mesin pemotong rumput. Setiap pekerja bertanggung jawab ătas alat dan bahan yang dipergunakan masing-masing.

\section{Anggaran Biaya Pengelolaan}

Anggaran biaya pemeliharaan bersumber dari biaya APBD Kota Bogor. Untukpengadaan alat dan bahan dalam kegiatan pemeliharaan ruang terbuka hijau se-Kota Bogor, Dinas Kebersihan dan Pertamanan mengeluarkan biaya sebesar Rp 193.312.600,00/tahun. Gaji pokok yang diberikan kepada petugas lapang sebesar Rp 1.250.000,00/bulan. Gaji tersebut sudah mencakup uang makan dan dapat diberikan perhari ataupun perbulan.

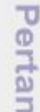

\section{Analisis Deskriptif}

\section{Analisis Aspek Fisik dan Biofisik \\ Kondisi Umum}

O Jenis tanah yang terdapat di Kelurahan Baranangsiang merupakan latosol coklat kemerahan. Lapisan bawah tanah berwarna coklat kemerahan, liat, remah, gembur. Banyak terdapat Fe dan Mn pada kedalaman 20-30 cm karena adanya proses penghancuran yang intensif sehingga terjadi penumpukan unsur tersebut (Dewi 2011). Kecepatan permeabilitas dan drainase latosol tergolong sedang sampai cukup cepat. Tanah jenis ini bereaksi cukup masam ( $\mathrm{pH} 5-7)$ dengan kadar bahan organik yang tergolong rendah (Yayat 2008; Dewi 2011; Yogia 2014). Soepardi dalam Yayat (2008) menjelaskan bahwa tanah latosol mempunyai produktivitas yang baik dan relatif lebih subur. Tanah jenis ini mudah meyerap air, sehingga tidak akan timbul genangan. Hal ini memberikan dampak positif bagi tanaman dalam proses penyerapan air. Jenis tanah tersebut memiliki tingkat kesuburan yang cukup tinggi sehingga dapat menunjang perkembangan dan pertumbuhan tanaman (Sudewa dalam Shodiq 2013), tetapi kandungan zat organik yang tergolong rendah harus ditunjang dengan pemberian pupuk. Kondisi curah hujan di Kelurahan Baranangsiang yang tinggi mempengaruhi frekuensi kegiatan penyiraman. Jika terjadi hujan, penyiraman tidak dilaksanakan.

\section{Sirkulasi dan Aksesibilitas}

Jalan Raya Pajajaan dan Jalan Otto Iskandardinata tergolong jalan arteri primer (RTRW Kota Bogor 2011-2031). Lebar badan jalan dari kedua jalan tersebut berkisar 10-11 meter. Menurut Peraturan Pemerintah No. 36 Tahun 2006 mengenai Jalan, lebar badan jalan minimal dari jalan arteri primer adalah $11 \mathrm{~m}$. 
Jalan Bina Marga, Jalan Padi, dan Jalan Pakuan tergolong jalan kolektor primer. Lebar jalan kolektor primer seharusnya adalah 9 m (Permen No. 36 Tahun 2006), sedangkan lebar dari ketiga jalan tersebut kurang dari $9 \mathrm{~m}$.

Sirkulasi di Jalan Raya Pajajaran, Jalan Otto Iskandardinata, Jalan Bina Marga, Jalan Padi dan Jalan Pakuan terbagi menjadi sirkulasi untuk pejalan kaki dan pengguna kendaraan bermotor. Tidak terdapat sirkulasi khusus yang ditujukan untuk pejalan kaki yang menyadang disabilitas dan pengguna sepeda. Pengguna sepeda harus menggunakan jalur kendaraan bermotor dan penyandang disabilitas harus menggunakan jalur pejalan kaki. Sirkulasi di tol hanya ditujukan untuk pengguna kendaraan bermotor. Pengguna sepeda yang menggunakan jalur kendaraan bermotor disajikan pada Gambar 12.

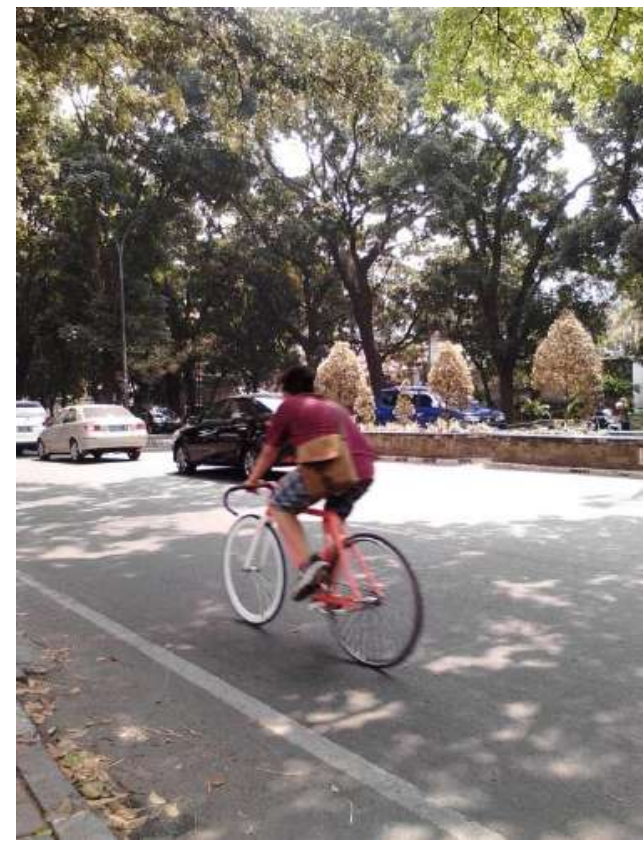

Gambar 12 Pengguna sepeda di jalur kendaraan bermotor Sumber: dokumentasi pribadi

Jalur pejalan kaki di Jalan Raya Pajajaran Segmen I s.d. III, di beberapa titik lokasi dapat dijumpai pedagang kaki lima yang berjualan dan menetap di jalur pejalan kaki dan pedagang yang berjualan di bahu jalan. Keberadaan pedagang kaki lima yang berjualan dan menetap di jalur pejalan kaki mengganggu pengguna jalan. Pedagang yang berjualan di bahu jalan juga dapat membahayakan keselamatan pejalan kaki karena dapat menghalangi jarak pandang saat menyebrang dan menghalangi jarak pandang dari kendaraan yang akan masuk ke ruko di sekitar jalur hijau (Gambar 13). 

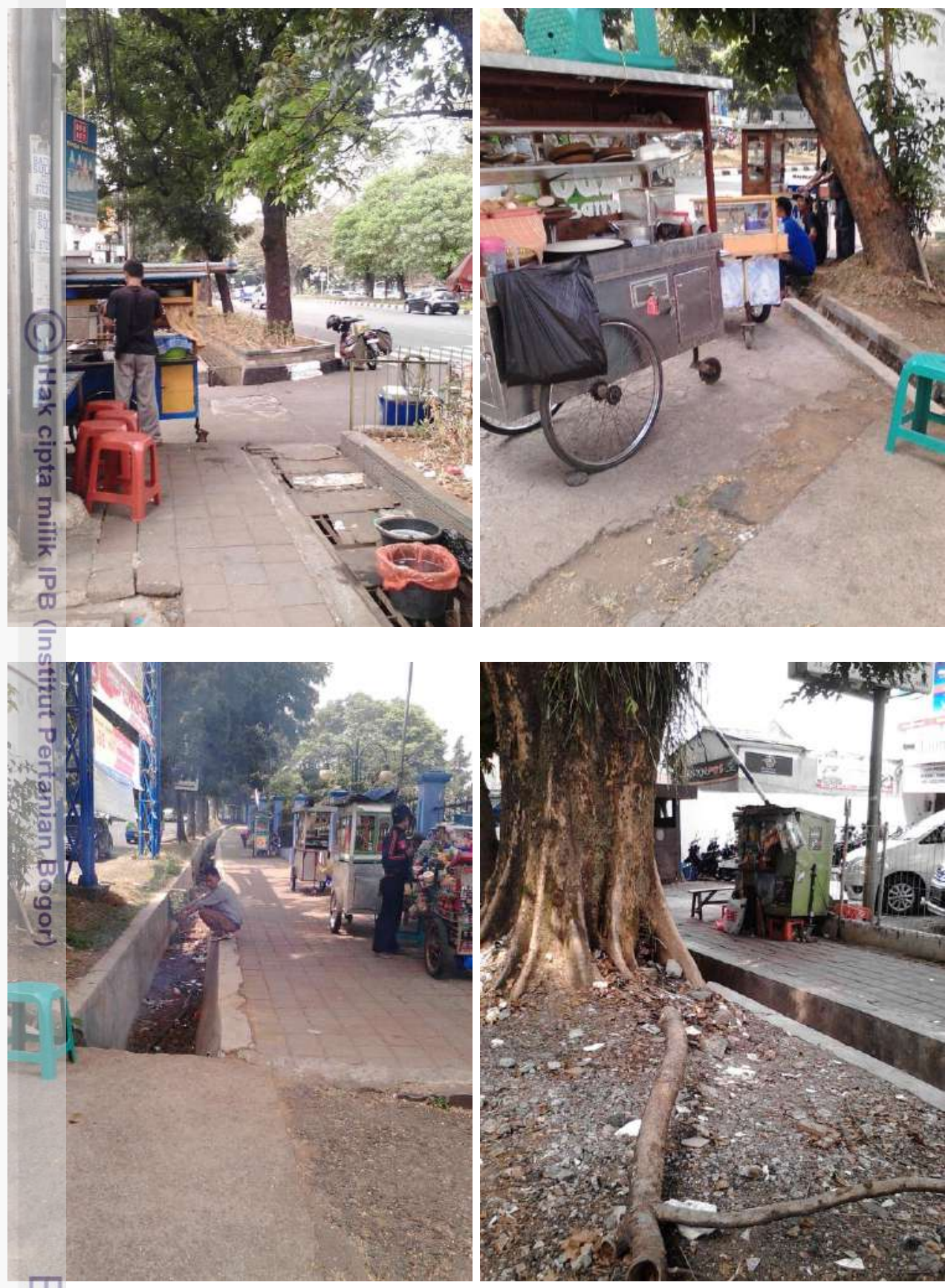

Gambar 13 Pedagang kaki lima di jalur pejalan kaki dan bahu jalan Sumber: dokumentasi pribadi

Terdapat beberapa penjual tanaman hias di Jalan Bina Marga. Yang berjualan di jalur hijau jalan. Penjual tanaman hias di Jalan Bina Marga menggunakan jalur pejalan kaki sebagai bagian dari tempat untuk berjualan. Hal ini mengganggu pejalan kaki, karena pejalan kaki harus menggunakan jalur kendaraan bermotor (Gambar 14). 


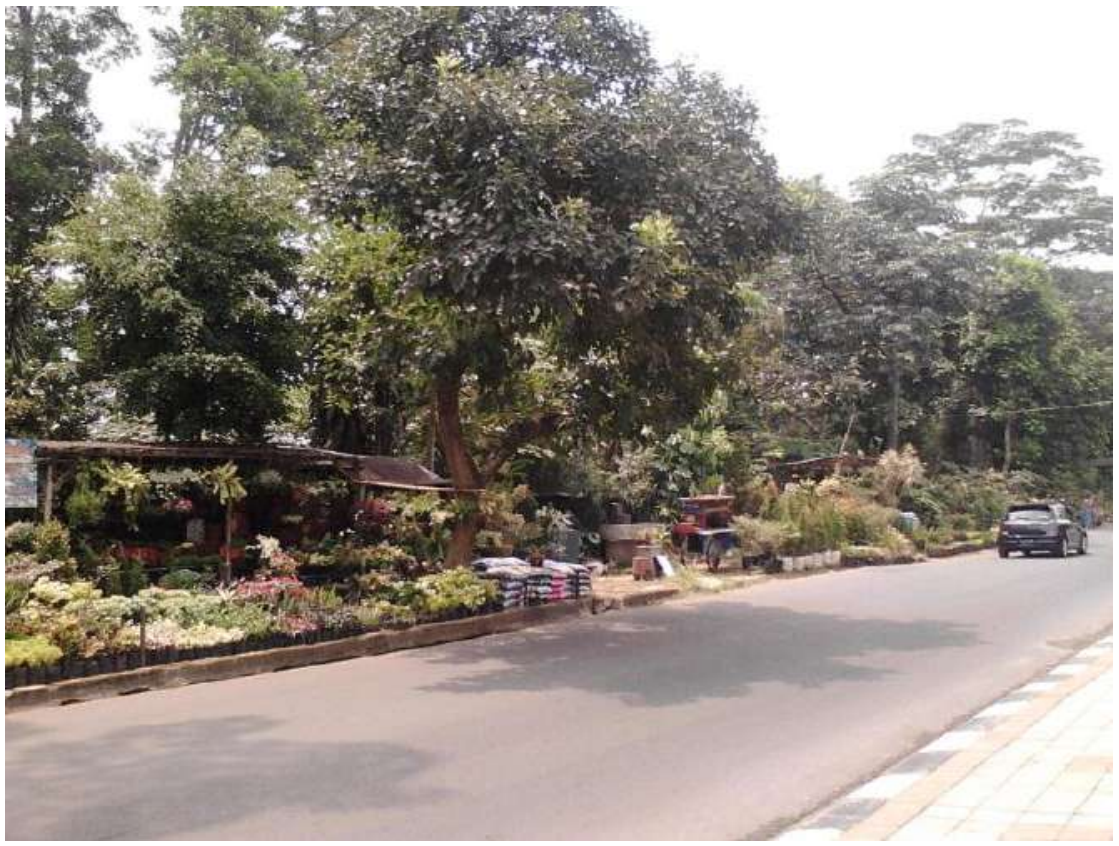

Gambar 14 Pedagang tanaman hias yang menggunakan jalur pejalan kaki Sumber: dokumentasi pribadi

Terdapat beberapa tanaman yang berada di tengah-tengah jalur pejalan kaki Jalan Pajajaran Segmen II. Lebar dari tajuk tanaman membuat pejalan kaki merasa tidak nyaman dan aman saat melintas (Gambar 15).

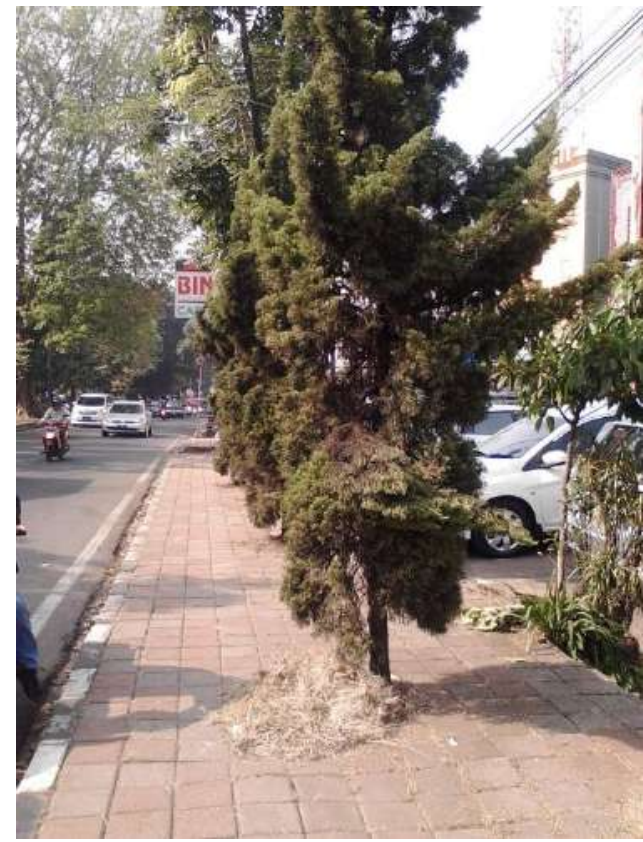

Gambar 15 Keberadaan tanaman di jalur pejalan kaki Sumber: dokumentasi pribadi 


\section{Hardscape dan Site Structure}

Beberapa elemen perkerasan dan site structure di jalur hijau jalan tidak hanya dikelola oleh Bidang Pertamanan dari Dinas Kebersihan dan Pertamanan (Tabel 26).

Tabel 26 Pihak pengelola site structure

\begin{tabular}{|c|c|c|}
\hline No. & Jenis Site Structure & Pihak Pengelola \\
\hline 1 & Rambu dan marka jalan & DLLAJ \\
\hline 2 & Signage & Pemilik (owner) dari masing-masing signage \\
\hline 3 & Lampu penerangan jalan & Seksi Penerangan Jalan Umum (PJU) dan \\
\hline 4 & $\frac{T}{7}$ & $\begin{array}{l}\text { Dekorasi Kota, DKP kota Bogor } \\
\text { DLLAJ }\end{array}$ \\
\hline 5 & Malte & DLLAJ \\
\hline 6 & Planter box & Bidang Pertamanan DKP Kota Bogor \\
\hline 7 & Pos DLLAJ & DLLAJ \\
\hline 8 & Fempat sampah & Warga \\
\hline 9 & Pagar & DLLAJ \\
\hline 10 & Bollard & DLLAJ \\
\hline
\end{tabular}

Sumber:- wawancara

$\stackrel{0}{2}$

E्Fengelolaan jalur pejalan kaki dan jalur kendaraan bermotor dikelola oleh Dinas PPekerjaan Umum (PU). Lampu penerangan yang terdapat pada tapak hanyałah lampu penerangan jalan untuk pengguna kendaraan bermotor (vehicular lighting). Tidak terdapat lampu penerangan jalan untuk pejalan kaki (pedestrian lighting). Berdasarkan sumber energi, lampu penerangan jalan yang digunakan di Kota Bogor terdiri dari lampu timer dan fotosel. Lampu penerangan jalan yang terdapât pada tapak adalah lampu timer yang diatur untuk menyala selama 12 jam mulai dari pukul 15.30 s.d. 5.30. Jarak antar lampu (gawangan) sekitar 30--40 m. Lampu dapat menyala optimal jika tidak terdapat gangguan. Terdapat beberapa faktor yang mempengaruhi kinerja lampu penerangan jalan, faktor vandalisme seperti kerusakan panel dan pencurian lampu, faktor kerusakan komponen lampu, dan faktor cuaca seperti petir serta angin kencang.

Kondisi hardscape dan site structure di setiap tapak berbeda-beda. Kondisi jalur kendaraan bermotor di Jalan Raya Pajajaran Segmen I tergolong baik. Kondisi paving di jalur pejalan kaki yang berada di median maupun tepi jalan cukup baik. Terdapat sedikit kerusakan di beberapa titik. Kondisi paving yang berbentuk kotak dan berpola rigid memberikan kesan formal. Analisis kondisi site structure di Jalan Raya Pajajaran Segmen I disajikan pada Tabel 27.

TabelC27 Analisi-sintesis site structure di Jalan Raya Pajajaran Segmen I

\begin{tabular}{|c|c|c|c|c|}
\hline No. & $\begin{array}{l}\text { Jenis Site } \\
\text { Structure }\end{array}$ & Kondisi & Analisis & Sintesis \\
\hline 1 & $\begin{array}{l}\text { Rambu } \\
\text { dản } \\
\text { marka } \\
\text { jatan } \\
\overline{\overline{3}}\end{array}$ & $\begin{array}{l}\text { Kurang } \\
\text { baik }\end{array}$ & $\begin{array}{l}\text { Semua rambu lalu lintas } \\
\text { dapat berfungsi dengan baik, } \\
\text { tetapi terdapat beberapa } \\
\text { marka jalan yang terhalang } \\
\text { oleh ranting dan daun } \\
\text { pohon. }\end{array}$ & $\begin{array}{l}\text { Bekerjasama dengan } \\
\text { DLLAJ untuk } \\
\text { melakukan monitoring } \\
\text { sehingga dapat } \\
\text { dilakukan tindakan } \\
\text { preventif. }\end{array}$ \\
\hline
\end{tabular}


Tabel 27 Analisi-sintesis site structure di Jalan Raya Pajajaran Segmen I (lanjutan)

\begin{tabular}{|c|c|c|c|c|}
\hline No. & $\begin{array}{l}\text { Jenis Site } \\
\text { Structure }\end{array}$ & Kondisi & Analisis & Sintesis \\
\hline 2 & Signage & Baik & $\begin{array}{l}\text { Kondisi signage yang } \\
\text { berada di median jalan } \\
\text { tidak mengganggu } \\
\text { jarak pandang } \\
\text { pengendara. }\end{array}$ & - \\
\hline (ก) & $\begin{array}{l}\text { Lampu } \\
\text { penerangan } \\
\text { jalan }\end{array}$ & Baik & $\begin{array}{l}\text { Lampu penerangan } \\
\text { jalan dapat menyala } \\
\text { dengan optimal. }\end{array}$ & - \\
\hline 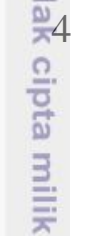 & $\begin{array}{l}\text { Jembatan } \\
\text { penyeberangan } \\
\text { orang (JPO) }\end{array}$ & $\begin{array}{l}\text { Kurang } \\
\text { baik }\end{array}$ & $\begin{array}{l}\text { Anak tangga yang } \\
\text { sudah berkarat dan } \\
\text { berlubang. }\end{array}$ & $\begin{array}{l}\text { Berkoordinasi } \\
\text { dengan DLLAJ } \\
\text { untuk melakukan } \\
\text { perbaikan } \\
\text { infrastruktur. }\end{array}$ \\
\hline 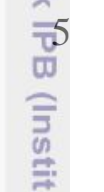 & Halte & $\begin{array}{l}\text { Kurang } \\
\text { baik }\end{array}$ & $\begin{array}{l}\text { Kondisinya kurang baik } \\
\text { akibat vandalisme, } \\
\text { tetapi masih dapat } \\
\text { digunakan. }\end{array}$ & $\begin{array}{l}\text { Berkoordinasi } \\
\text { dengan DLLAJ } \\
\text { untuk dilakukan } \\
\text { pengecatan. }\end{array}$ \\
\hline $\begin{array}{l}50 \\
70 \\
0 \\
\frac{1}{2}\end{array}$ & Planter box & $\begin{array}{l}\text { Kurang } \\
\text { baik }\end{array}$ & $\begin{array}{l}\text { Terdapat beberapa } \\
\text { planter box yang pecah } \\
\text { dan berlumut. }\end{array}$ & $\begin{array}{l}\text { Pembersihan planter } \\
\text { box. }\end{array}$ \\
\hline 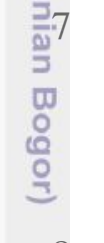 & Pos DLLAJ & Baik & $\begin{array}{l}\text { Pos DLLAJ digunakan } \\
\text { oleh DLLAJ untuk } \\
\text { berjaga dan memantau } \\
\text { arus kendaraan lalu } \\
\text { lintas. }\end{array}$ & - \\
\hline$\infty$ & Tempat sampah & Baik & $\begin{array}{l}\text { Tempat sampah yang } \\
\text { terdapat di segmen ini } \\
\text { merupakan tempat } \\
\text { sampah pribadi yang } \\
\text { dengan sengaja } \\
\text { ditempatkan oleh warga } \\
\text { di dekat jalur pejalan } \\
\text { kaki agar pengguna } \\
\text { jalan dapat } \\
\text { memanfaatkannya. }\end{array}$ & $\begin{array}{l}\text { Menambah jumlah } \\
\text { tempat sampah. }\end{array}$ \\
\hline 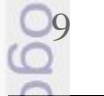 & Pagar & Baik & $\begin{array}{l}\text { Tidak ada pagar yang } \\
\text { rusak. }\end{array}$ & - \\
\hline
\end{tabular}

Pada segmen ini, pola penempatan planter box yang berada di median, (disusun mengikuti pola jalan. Bentuk dari planter box tersebut memberikan kesan terstruktur, solid, kuat, logis, dan tersusun (Gambar 16). 


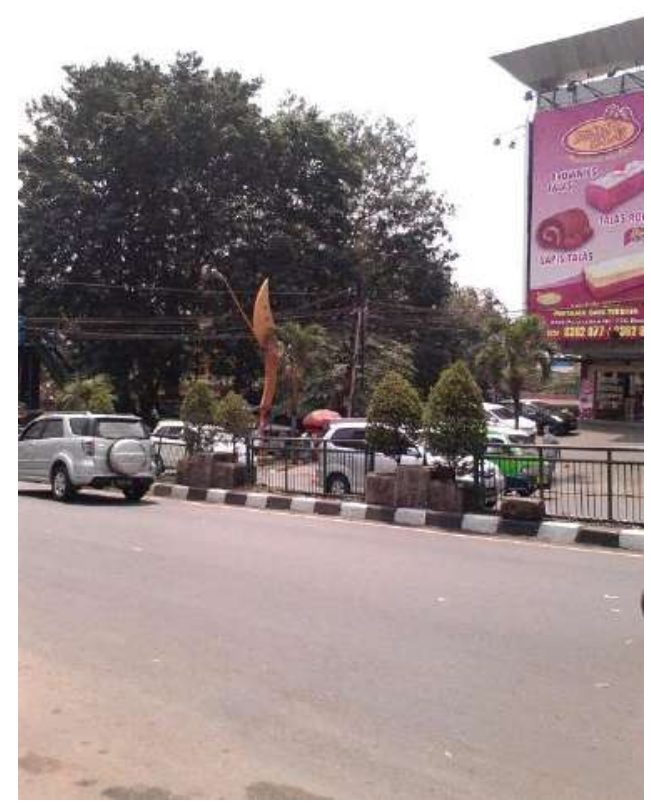

Gambar 16 Planter box di median jalan Sumber: dokumentasi pribadi

Kondisi jalur kendaraan bermotor di Jalan Raya Pajajaran Segmen II sangateaik. Kondisi paving di jalur pejalan kaki yang berada di median ataupun tepi jậlan cukup baik. Terdapat sedikit kerusakan di beberapa titik. Analisis kondiş̧ site structure di Jalan Raya Pajajaran Segmen I disajikan pada Tabel 28.

(

Tabel 28 Analisis-sintesis site structure di Jalan Raya Pajajaran Segmen II

\begin{tabular}{|c|c|c|c|c|}
\hline No. & $\begin{array}{l}\text { Jenis Site } \\
\text { Structure }\end{array}$ & Kondisi & Analisis & Sintesis \\
\hline 1 & $\begin{array}{l}\text { Rambu dan } \\
\text { marka jalan }\end{array}$ & Baik & $\begin{array}{l}\text { Rambu lalu lintas yang } \\
\text { terdapat di median ataupun } \\
\text { tepi jalan hanya berfungsi } \\
\text { pada malam hari. } \\
\text { Berdasarkan hasil } \\
\text { wawancara dan } \\
\text { pengamatan lapang, } \\
\text { terdapat beberapa marka } \\
\text { jalan yang tak terlihat oleh } \\
\text { pengendara kendaraan } \\
\text { bermotor. Hal ini } \\
\text { diakibatkan oleh papan } \\
\text { iklan yang terletak di } \\
\text { dekat marka. }\end{array}$ & $\begin{array}{l}\text { Diperlukan } \\
\text { koordinasi dengan } \\
\text { pihak terkait. }\end{array}$ \\
\hline 2 & $\begin{array}{l}\text { Signage } \\
\text { 을 }\end{array}$ & Baik & $\begin{array}{l}\text { Signage tidak } \\
\text { mengganggu jarak } \\
\text { pandang. }\end{array}$ & - \\
\hline 3 & $\begin{array}{l}\text { Planter box } \\
\frac{\bar{C}}{3}\end{array}$ & Baik & $\begin{array}{l}\text { Beberapa planter box } \\
\text { sudah tidak digunakan. }\end{array}$ & $\begin{array}{l}\text { Dimanfaatkan } \\
\text { kembali dengan } \\
\text { cara menanam } \\
\text { tanaman baru. }\end{array}$ \\
\hline
\end{tabular}


Tabel 28 Analisis-sintesis site structure di Jalan Raya Pajajaran Segmen II (lanjutan)

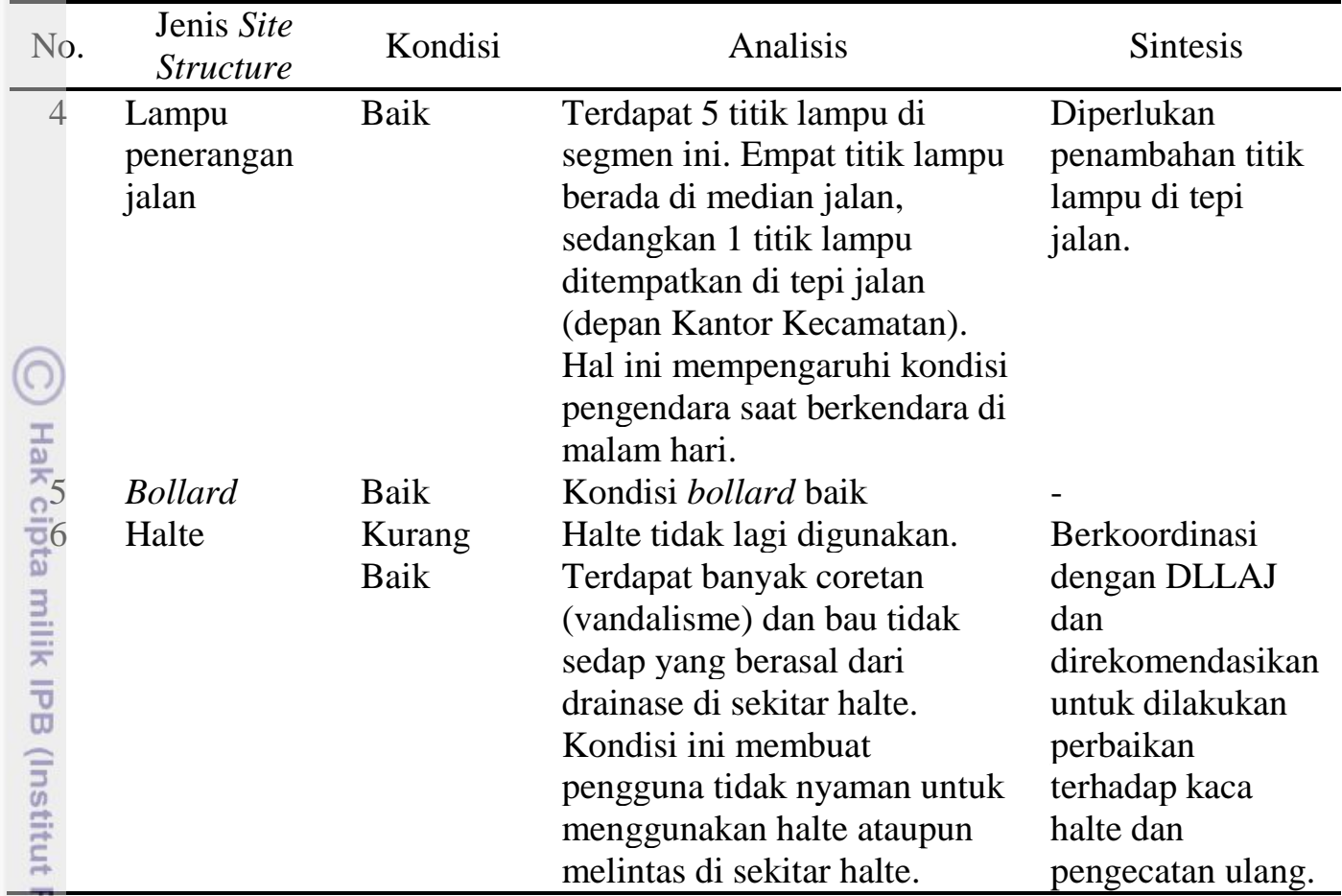

Tidak terdapat tempat sampah di sepanjang jalur hijau tepi jalan Segmen II. Oleh sebab itu, diperlukan penambahan fasilitas tempat sampah. Terdapat banyak sampah di jalur hijau, jalur pejalan kaki, dan drainase.

Kondisi jalur kendaraan bermotor pada jalur hijau Jalan Raya Pajajaran Segmen III baik. Banyak paving yang rusak di jalur pejalan kaki yang berada di median maupun tepi jalan. Hal ini membuat pengguna jalan merasa tidak nyaman (Gambar 17). Analisis kondisi site structure di disajikan pada Tabel 29.

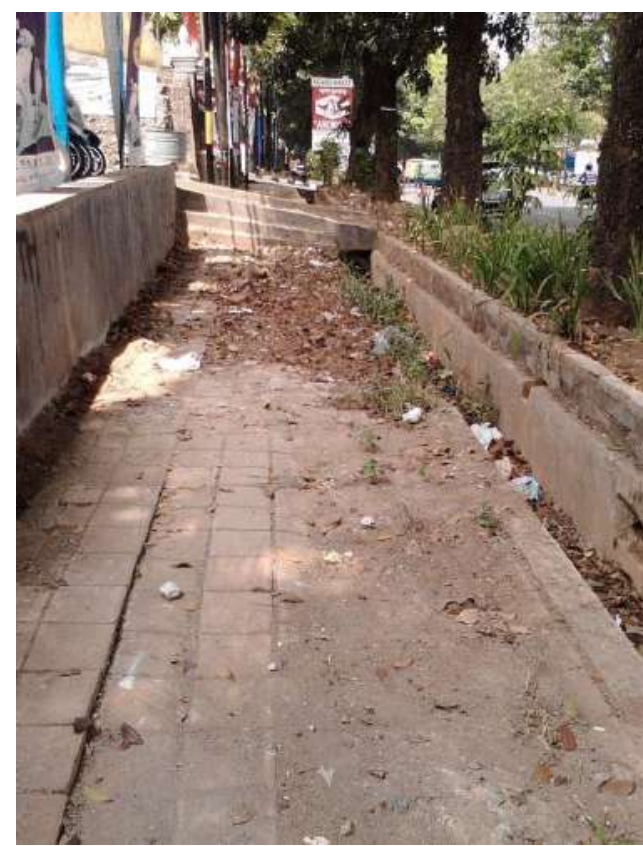

Gambar 17 Paving yang rusak di jalur pejalan kaki Sumber: dokumentasi pribadi 
Tabel 29 Analisis-sintesis site structure di Jalan Raya Pajajaran Segmen III

\begin{tabular}{|c|c|c|c|c|}
\hline No. & $\begin{array}{l}\text { Jenis Site } \\
\text { Structure }\end{array}$ & Kondisi & Analisis & Sintesis \\
\hline 1 & $\begin{array}{l}\text { Rambu dan } \\
\text { marka jalan }\end{array}$ & Baik & $\begin{array}{l}\text { Rambu dan marka jalan } \\
\text { dapat terlihat dengan jelas }\end{array}$ & - \\
\hline 2 & Signage & Baik & $\begin{array}{l}\text { Kondisi signage tidak } \\
\text { mengganggu jarak } \\
\text { pandang }\end{array}$ & - \\
\hline 3 & $\begin{array}{l}\text { Lampu } \\
\text { penerangan } \\
\text { jalan } \\
\frac{1}{\frac{1}{2}} \\
\frac{\hat{2}}{\frac{0}{0}}\end{array}$ & Baik & $\begin{array}{l}\text { Lampu penerangan pada } \\
\text { segmen ini hanya terdapat } \\
\text { di median jalan }\end{array}$ & $\begin{array}{l}\text { Berokordinasi } \\
\text { dengan Seksi PJU } \\
\text { dan Dekorasi kota } \\
\text { untuk menambah } \\
\text { jumlah lampu di tepi } \\
\text { jalan. }\end{array}$ \\
\hline 4 & Bollard & Baik & Kondisi bollard baik & - \\
\hline 5 & 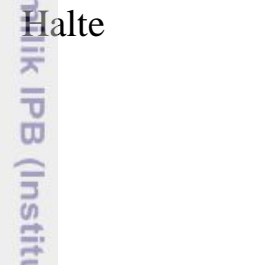 & $\begin{array}{l}\text { Kurang } \\
\text { Baik }\end{array}$ & $\begin{array}{l}\text { Kondisi halte kurang baik } \\
\text { karena adanya vandalisme, } \\
\text { tetapi halte masih } \\
\text { digunakan oleh warga } \\
\text { setempat atau pengguna } \\
\text { jalan. }\end{array}$ & $\begin{array}{l}\text { Berkoordinasi } \\
\text { dengan DLLAJ } \\
\text { untuk dilakukan } \\
\text { pengecatan ulang. }\end{array}$ \\
\hline 6 & $\begin{array}{l}\text { Fempat } \\
\text { sampah } \\
\text { sampa }\end{array}$ & Baik & $\begin{array}{l}\text { Tempat sampah yang ada } \\
\text { belum memadai }\end{array}$ & $\begin{array}{l}\text { Penambahan tempat } \\
\text { sampah di beberapa } \\
\text { titik lokasi. }\end{array}$ \\
\hline
\end{tabular}

Kondisi jalur kendaraan bermotor dan jalur pejalan kaki di Jalan Otto Iskandardinata tergolong baik (Gambar 18). Analisis dan sintesis mengenai site structure disajikan pada Tabel 30.

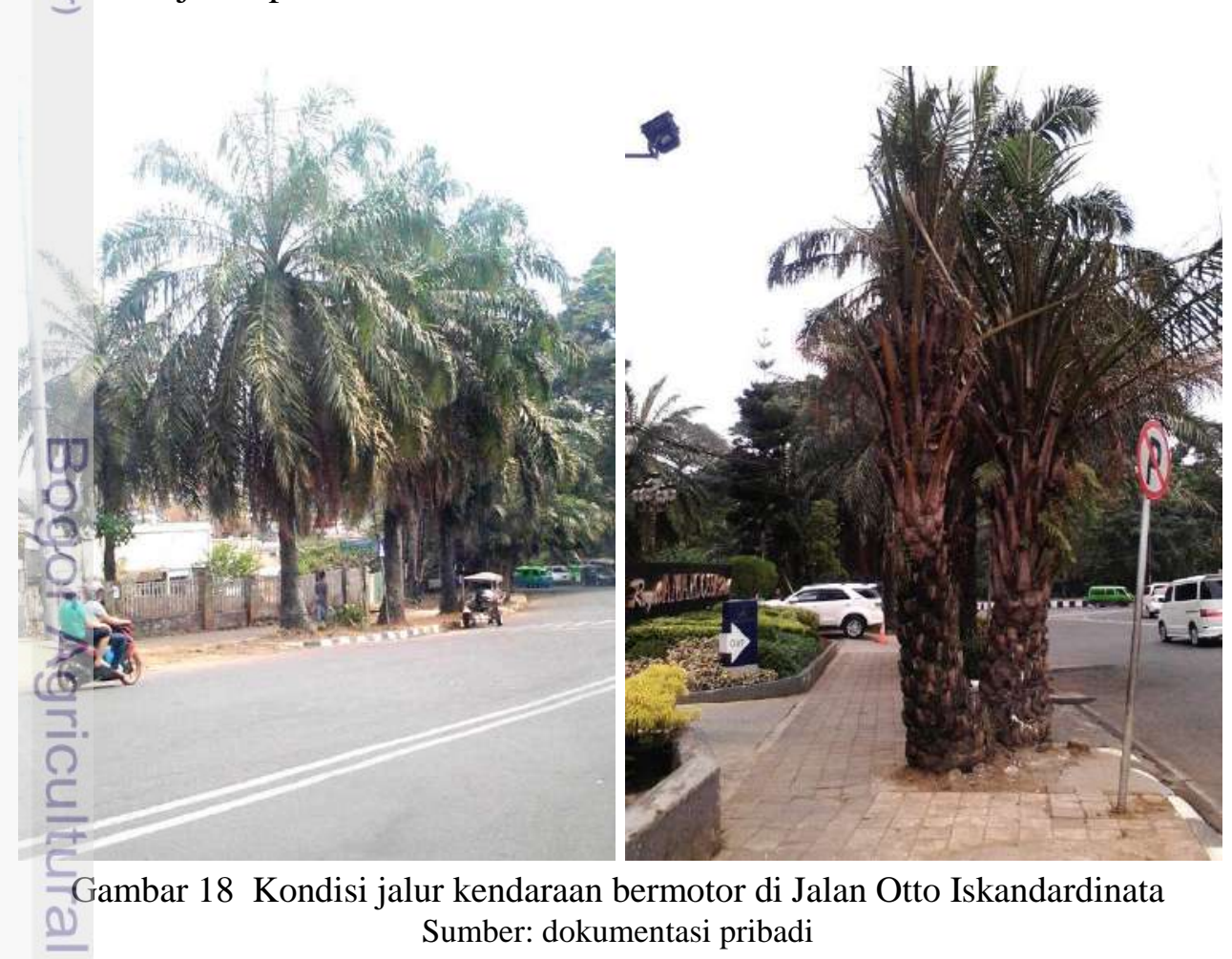


Tabel 30 Analisis-sintesis site structure di Jalan Otto Iskandardinata

\begin{tabular}{|c|c|c|c|c|}
\hline No. & Jenis Site Structure & Kondisi & Analisis & Sintesis \\
\hline 1 & $\begin{array}{l}\text { Rambu dan marka } \\
\text { jalan }\end{array}$ & Baik & $\begin{array}{l}\text { Rambu dan marka dapat } \\
\text { terlihat dengan jelas. }\end{array}$ & - \\
\hline 2 & Signage & Baik & $\begin{array}{l}\text { Signage tidak mengganggu } \\
\text { jarak pandang. }\end{array}$ & - \\
\hline $\begin{array}{l}\text { (O) } \\
\frac{1}{2}\end{array}$ & $\begin{array}{l}\text { Lampu penerangan } \\
\text { jalan }\end{array}$ & Baik & $\begin{array}{l}\text { Hanya terdapat satu lampu } \\
\text { penerangan jalan di tepi jalan } \\
\text { sehingga saat malam hari } \\
\text { kondisi jalan begitu gelap. }\end{array}$ & $\begin{array}{l}\text { Penambahan } \\
\text { jumlah lampu } \\
\text { jalan (lampu } \\
\text { TL/ } \\
\text { flourescent) di } \\
\text { tepi jalan. }\end{array}$ \\
\hline
\end{tabular}

Tidak terdapat tempat sampah di sepanjang jalur hijau tepi jalan. Oleh sebab itu diperlukan penambahan fasilitas tempat sampah. Kondisi jalur kendaraan bermotor di Tol Jagorawi tergolong baik. Kondisi site structure secara keseluruhan tergolong baik (Tabel 31)

๘

解年el 31 Analisis-sintesis site structure di Tol Jagorawi

\begin{tabular}{|c|c|c|c|c|}
\hline No. & Jenis Site Structure & Kondisi & Analisis & Sintesis \\
\hline 군 1 & $\begin{array}{l}\text { Rambu dan marka } \\
\text { jalan }\end{array}$ & Baik & $\begin{array}{l}\text { Rambu dan marka dapat } \\
\text { terlihat dengan jelas. }\end{array}$ & - \\
\hline כ2. & $\begin{array}{l}\text { Lampu penerangan } \\
\text { jalan }\end{array}$ & Baik & $\begin{array}{l}\text { Lampu jalan berfungsi } \\
\text { dengan optimal. }\end{array}$ & - \\
\hline
\end{tabular}

Kondisi jalur kendaraan bermotor di Jalan Bina marga tergolong baik, tetapi kondisi jalur pejalan kaki di Jalan Bina Marga kurang baik karena terdapat paving yang rusak di beberapa titik lokasi. Kondisi site structure dan paving di Jalan Bina Marga disajikan pada Gambar 19.

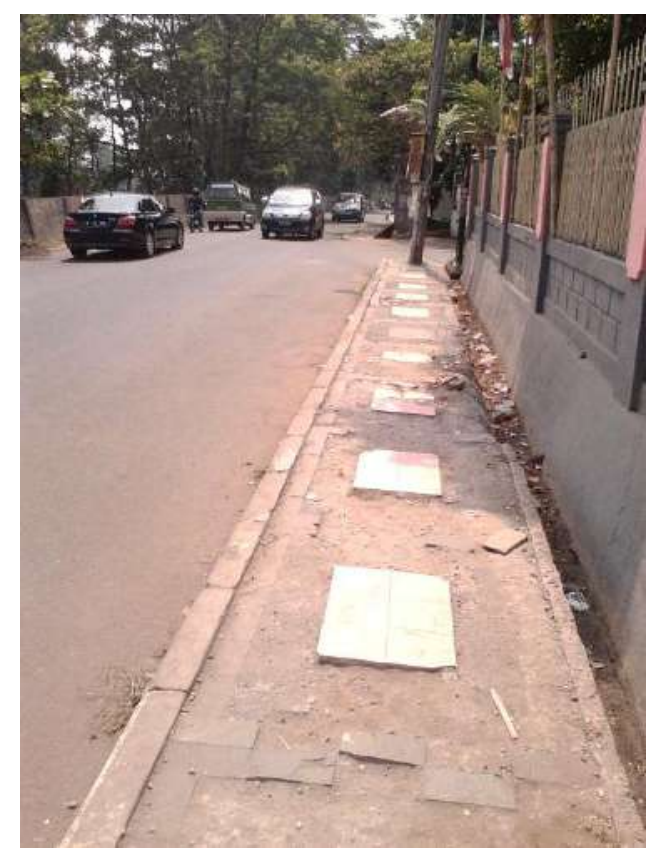

Gambar 19 Kondisi paving dan drainase di Jalan Bina Marga Sumber: dokumentasi pribadi 
Tabel 32 Analisis-sintesis site structure di Jalan Bina Marga

\begin{tabular}{|c|c|c|c|c|}
\hline No. & $\begin{array}{l}\text { Jenis Site } \\
\text { Structure }\end{array}$ & Kondisi & Analisis & Sintesis \\
\hline 1 & $\begin{array}{l}\text { Rambu dan } \\
\text { marka jalan }\end{array}$ & Baik & $\begin{array}{l}\text { Rambu dan marka dapat terlihat } \\
\text { dengan jelas. }\end{array}$ & - \\
\hline 2 & $\begin{array}{l}\text { Lampu } \\
\text { penerangan } \\
\text { jalan }\end{array}$ & Baik & $\begin{array}{l}\text { Lampu jalan berfungsi dengan } \\
\text { optimal. }\end{array}$ & - \\
\hline 3 & Patung & Baik & Point of interest. & - \\
\hline 4 & 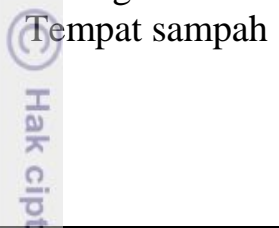 & Baik & $\begin{array}{l}\text { Tempat sampah yang terdapat } \\
\text { di tepi jalan merupakan tempat } \\
\text { sampah milik warga yang } \\
\text { dengan sengaja diperuntukkan } \\
\text { untuk umum. }\end{array}$ & $\begin{array}{l}\text { Perlu } \\
\text { penambahan } \\
\text { tempat sampah }\end{array}$ \\
\hline
\end{tabular}

Kondisi jalur kendaraan bermotor di Jalan Padi tergolong baik, namun kondišsi jalur pejalan kaki kurang baik. Terdapat banyak pedagang, tanaman, sampah, dan paving yang rusak di beberapa titik lokasi (Gambar 20). Analisis kondist site structure disajikan pada Tabel 33.

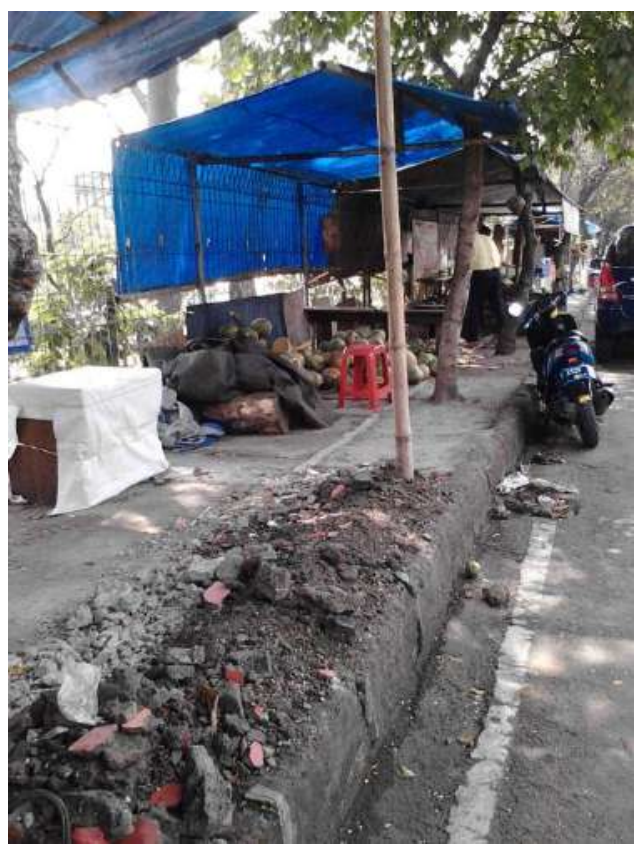

Gambar 20 Kondisi paving di Jalan Padi Sumber: dokumentasi pribadi

Tabel 33 Analisis-sintesis site structure di Jalan Padi

\begin{tabular}{|c|c|c|c|c|}
\hline No. & $\begin{array}{l}\text { Jenis Site } \\
\text { Structure } \\
\end{array}$ & Kondisi & Analisis & Sintesis \\
\hline 1 & $\begin{array}{l}\text { Rambu dan } \\
\text { marka jalan }\end{array}$ & Baik & $\begin{array}{l}\text { Rambu dan marka dapat } \\
\text { terlihat dengan jelas. }\end{array}$ & \\
\hline 2 & $\begin{array}{l}\text { Eampu } \\
\text { penerangan } \\
\text { galan }\end{array}$ & Baik & $\begin{array}{l}\text { Lampu jalan berfungsi dengan } \\
\text { optimal. }\end{array}$ & - \\
\hline
\end{tabular}

(tabel berlanjut) 
Tabel 33 Analisis-sintesis site structure di Jalan Padi (lanjutan)

\begin{tabular}{|c|c|c|c|c|}
\hline No. & $\begin{array}{l}\text { Jenis Site } \\
\text { Structure }\end{array}$ & Kondisi & Analisis & Sintesis \\
\hline (م) & Tempat sampah & Baik & $\begin{array}{l}\text { Ukuran tempat sampah cukup } \\
\text { besar, tetapi banyak sampah } \\
\text { yang tercecer ke arah jalur } \\
\text { pejalan kaki. Kondisi bau tidak } \\
\text { sedap dari sampah membuat } \\
\text { pengguna jalan tidak nyaman. } \\
\text { Hanya terdapat satu tempat } \\
\text { sampah. }\end{array}$ & $\begin{array}{l}\text { Perlu } \\
\text { penambahan } \\
\text { tempat sampah } \\
\text { umum. }\end{array}$ \\
\hline
\end{tabular}

Vegetasi

Pola penanaman pohon di jalur hijau Jalan Raya Pajajaran Segmen I mengikuti bentuk jalan dengan jarak tanam tertentu. Vegetasi ditanam sesuai đengan pedoman penataan vegetasi di tepian jalan raya ataupun tol, yaitu ditanam secara masal dan bervariasi. Penempatan vegetasi berjenis perdu, semak, ground Eover, dan tanaman rambat tidak ditampilkan secara individu atau spot-spot kecil, sehingga tertangkap oleh pejalan kaki dan pengemudi kendaraan.

\# Penanaman secara masal bertujuan untuk efisiensi biaya. Selain itu, vegetasi yang terdapat pada jalur hijau dapat terlihat menyatu dengan lingkungan disekitarnya. Kombinasi warna, bentuk tajuk dan tinggi dari tanaman mencegah suasana monoton dan menambah nilai estika. Keragaman vegetasi pada segmen mini tergolong tinggi (Gambar 20).
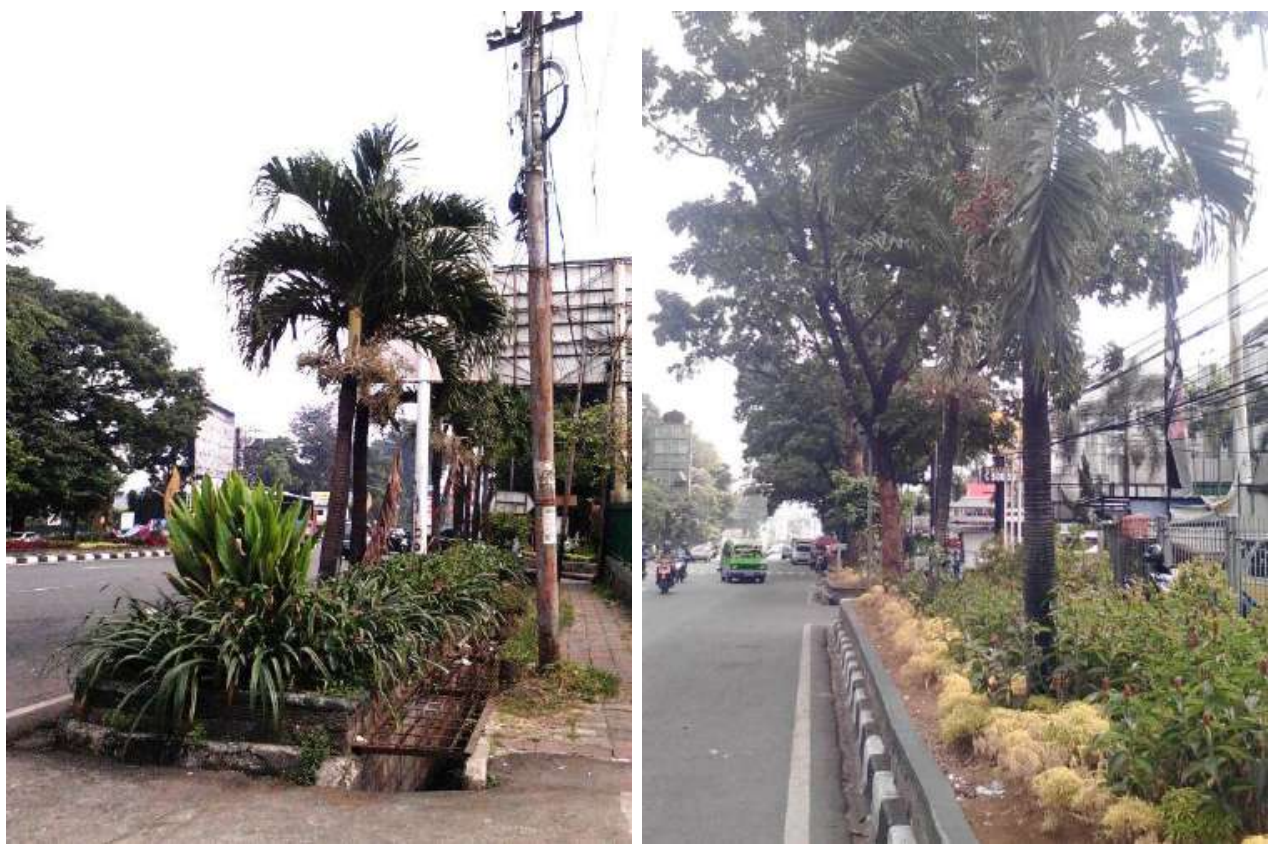

Gambar 21 Keragaman vegetasi

Sumber: dokumentasi pribadi

Semak yang mendominasi jalur hijau bagian tepi adalah pacing (Costus Woodsoni) dan sedangkan yang mendominasi median adalah agave (Agave sp.). 
Perdu yang mendominasi tepi jalan adalah hanjuang merah (Cordyline terminalis 'Rededge'), sedangkan yang mendominasi median adalah dracena (Dracaena marginata 'Tricolor'). Pohon yang mendominasi jalur hijau jalan adalah pucuk merah (Syzygium oleina).

Pola penanaman pohon yang mengikuti pola sirkulasi memberikan kesan pengarah (fungsi pengarah) bagi pengguna kendaraan bermotor dan pejalan kaki. Adanya repetisi dari satu jenis pohon dalam satu segmen memberikan kesan rapi dan teratur. Warna cerah dari daun simbang darah (Iresine herbstii) dan ubi jalar (Iphomea batatas) yang terdapat di median memberikan kesan relax. Warna kuning dari brokoli (Oleacea sp.) dan pacing (Costus woodsoni) di salah satu sisi jalur hijau bagian tepi memberikan kesan riang. Pada segmen ini tercipta suasana kontra $\bar{s}$ di median jalan yang berasal dari kombinasi warna merah dari simbang darah Tresine herbstii) dan warna hijau dari ubi jalar (Iphomea batatas) (Gambar 22).

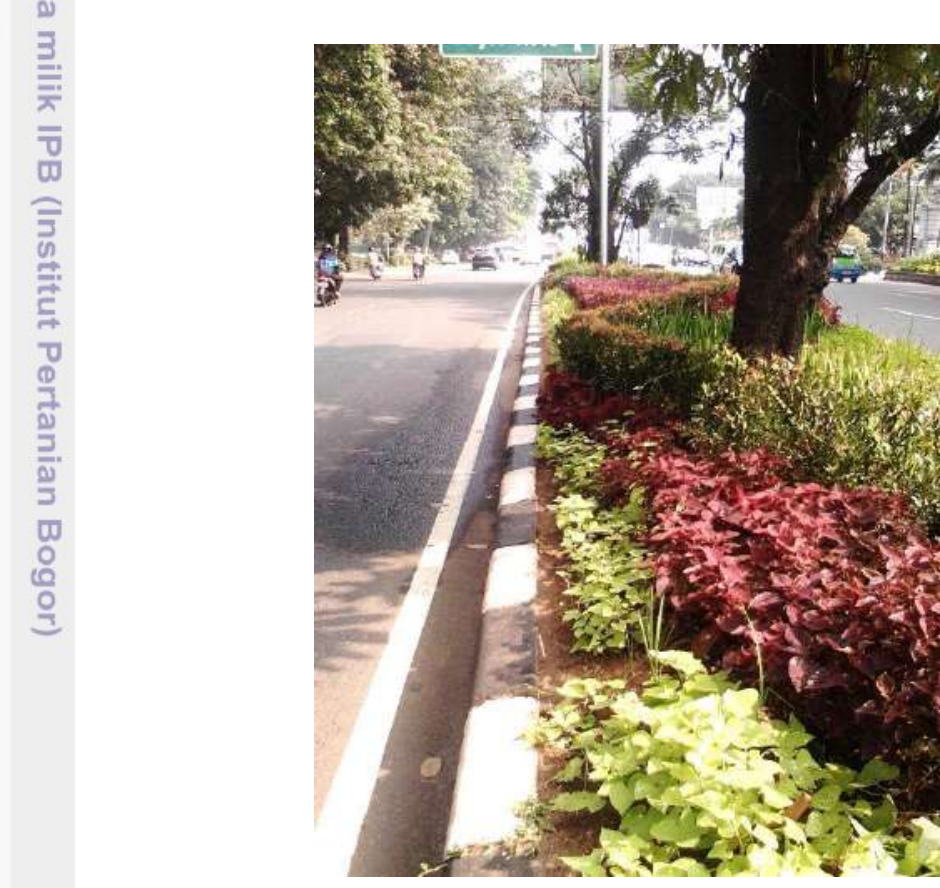

Gambar 22 Warna kontas di median

Sumber: dokumentasi pribadi

Terdapat pohon bintaro (Cerbera manghas) pada segmen ini. Pohon tersebut merupakan tanaman buah dan beracun yang seharusnya tidak ditempatkan di jalur hijau. Pada segmen ini, tidak terdapat pohon yang berfungsi sebagai peredam kebisingan. Fungsi pohon yang mendominasi pada adalah fungsi estetika dan pengarah jalan (Tabel 34).

Tabel34 Nama dan fungsi pohon di Jalan Raya Pajajaran Segmen I

\begin{tabular}{|c|c|c|c|c|c|c|c|c|c|}
\hline \multirow{2}{*}{ No. } & \multirow{2}{*}{ Nama Ilmiah } & \multirow{2}{*}{ Nama Lokal } & \multicolumn{7}{|c|}{ Fungsi* } \\
\hline & & & 1 & 2 & 3 & 4 & 5 & 6 & 7 \\
\hline 1 & Cerbera manghas & Bintaro & $\sqrt{ }$ & & & & & & \\
\hline 2 & Ginnamomun burmanii & Kayu manis & $\sqrt{ }$ & $\sqrt{ }$ & & & & & $\sqrt{ }$ \\
\hline
\end{tabular}


Tabel 34 Nama dan fungsi pohon di Jalan Raya Pajajaran Segmen I (lanjutan)

\begin{tabular}{|c|c|c|c|c|c|c|c|c|c|}
\hline \multirow{2}{*}{ No. } & \multirow{2}{*}{ Nama Ilmiah } & \multirow{2}{*}{ Nama Lokal } & \multicolumn{7}{|c|}{ Fungsi* } \\
\hline & & & 1 & 2 & 3 & 4 & 5 & 6 & 7 \\
\hline 3 & Erythrina crista galli & Dadap merah & & $\sqrt{ }$ & $\sqrt{ }$ & $\sqrt{ }$ & & & \\
\hline 4 & Ficus benjamina & Beringin & $\sqrt{ }$ & & $\sqrt{ }$ & $\sqrt{ }$ & & $\sqrt{ }$ & \\
\hline 5 & Ficus elastica 'Rubra' & Beringin karet & $\sqrt{ }$ & & & & & & \\
\hline 6 & Muthingia calabura & Kersen & & & $\sqrt{ }$ & & & & \\
\hline 8 & Sygyzium oleina & Pucuk merah & & $\sqrt{ }$ & & & & & $\sqrt{ }$ \\
\hline 8 & Pterocarpus indicus & Angsana & & $\sqrt{ }$ & $\sqrt{ }$ & $\sqrt{ }$ & & $\sqrt{ }$ & \\
\hline $\bar{T} 9$ & Stenolobium stans & Tekoma & $\sqrt{ }$ & & & $\sqrt{ }$ & & & \\
\hline dิ 0 & Sweitenia mahogani & Mahoni & & $\sqrt{ }$ & $\sqrt{ }$ & $\sqrt{ }$ & & $\sqrt{ }$ & \\
\hline 1 & Veitchia merilii & Palem putri & $\sqrt{ }$ & $\sqrt{ }$ & & & & & \\
\hline
\end{tabular}

*Keterangan 1 = estetika, 2 = pengarah jalan, 3 = peneduh, 4 =penyerap polusi udara, 5 =peredam kebisingan, 6 = pemecah angin, 7 =border

Vegetasi di jalur hijau Jalan Raya Pajajaran Segmen II juga ditanam secara Enasal dan bervariasi. Jenis vegetasi yang mendominasi adalah jenis pohon. Ground cover yang mendominasi median jalan adalah rumput (Axonopus Eompresus), sedangkan ground cover yang mendominasi jalur hijau tepi jalan adalah brokoli (Olenacea sp.). Semak yang mendominasi segmen ini adalah spider ظily (Hymenocallis spectosa). Perdu yang mendominasi adalah lolipop (Pachytachys lutea). Keragaman vegetasi pada segmen ini tidak terlalu tinggi. Pola penanaman pohon, semak, perdu, dan ground cover di tepi jalan berbentuk Ginear atau mengikuti bentuk jalan dengan jarak tanam tertentu (Gambar 23).

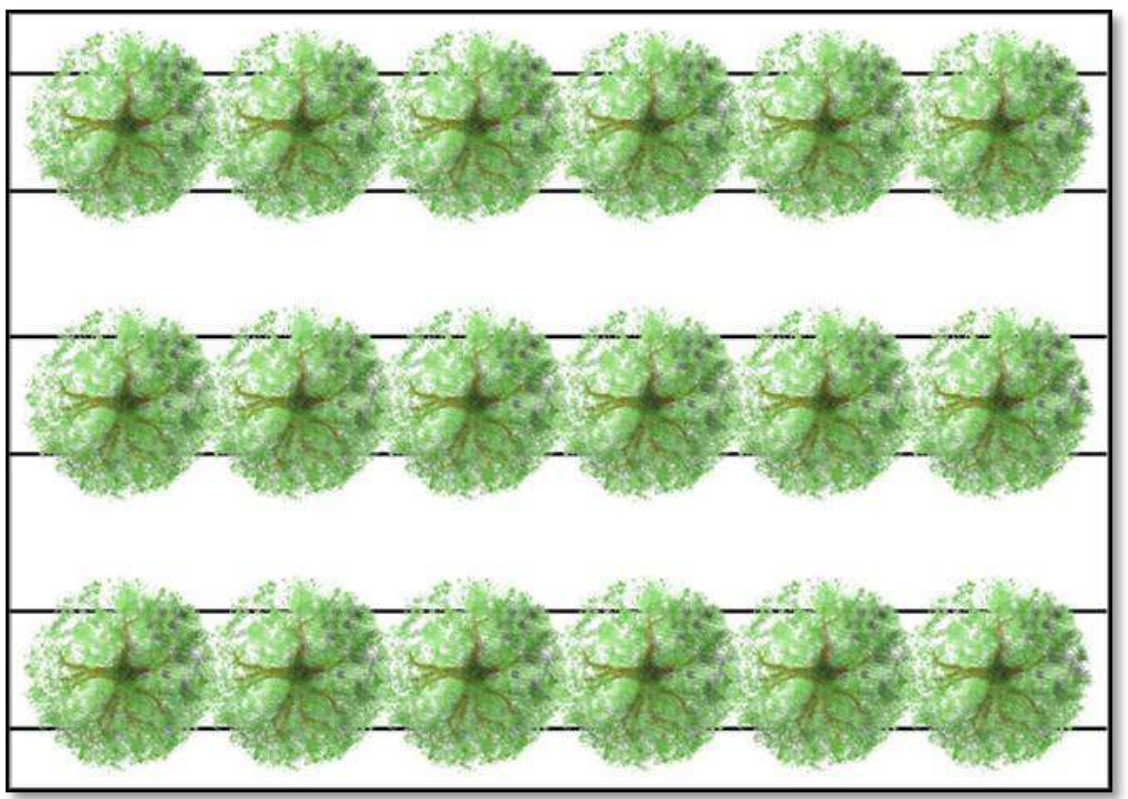

Gambar 23 Pola penanaman vegetasi Sumber: dokumentasi pribadi 
Penanaman semak dan ground cover seperti brokoli (Olenacea sp.) dan spider lily (Hymenocallis spectosa) yang mendominasi salah satu sisi jalur hijau tepi jalan memberikan kesan monoton dan kesan pembatas (border) antara pejalan kaki dengan jalur kendaraan bermotor. Kondisi semak, ground cover, dan perdu di tepi jalan kurang terawat dengan baik. Beberapa tanaman terlihat layu dan belum dipangkas. Kondisi ini dapat menimbulkan kesan negatif (Gambar 24).

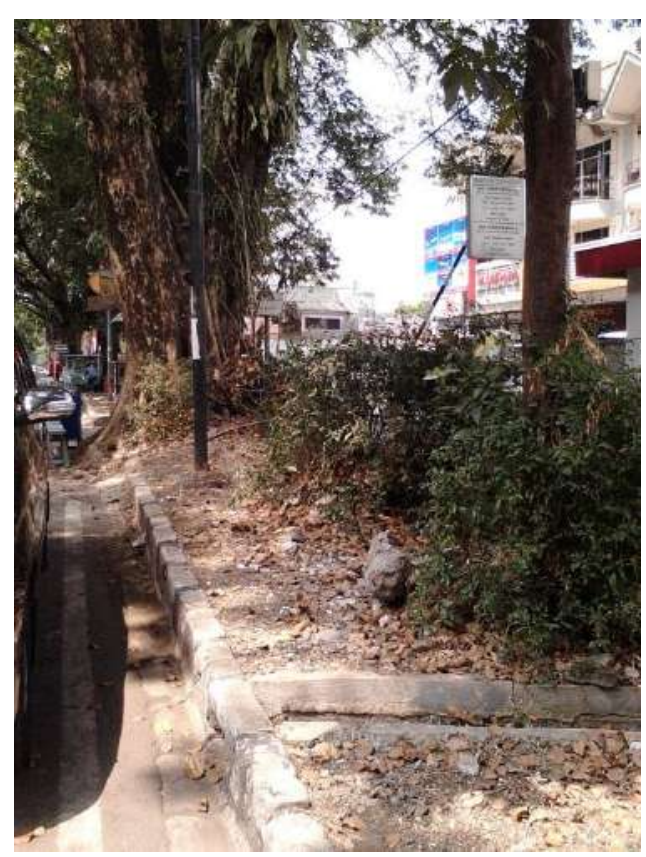

Gambar 24 Kondisi tanaman yang belum dipangkas Sumber: dokumentasi pribadi

Terdapat beberapa ground cover yang dapat menyerap NO, yaitu sansivera (Sansivieria sp.) dan sri rejeki (Aglaonema sp.). Pada segmen ini juga terdapat pohon bintaro (Cerbera manghas) yang merupakan jenis tanaman buah dan beracun. Hal ini bertentangan dengan standar penanaman jalur hijau. Pada segmen ini, tidak terdapat pohon yang berfungsi sebagai peredam kebisingan. Fungsi pohon yang mendominasi adalah fungsi penyerap polusi udara (Tabel 35).

Tabel 35 Nama dan fungsi pohon di Jalan Raya Pajajaran Segmen II

\begin{tabular}{|c|c|c|c|c|c|c|c|c|c|}
\hline \multirow{2}{*}{ No. } & \multirow{2}{*}{ Nama Ilmiah } & \multirow{2}{*}{ Nama Lokal } & \multicolumn{7}{|c|}{ Fungsi* } \\
\hline & & & 1 & 2 & 3 & 4 & 5 & 6 & 7 \\
\hline 1 & Adenanthera pavonia & Saga & & & $\sqrt{ }$ & $\sqrt{ }$ & & & \\
\hline 2 & $\bar{B}$ auhinia purpurea & $\begin{array}{l}\text { Bunga kupu- } \\
\text { kupu }\end{array}$ & $\sqrt{ }$ & $\sqrt{ }$ & & $\sqrt{ }$ & & & \\
\hline 3 & Ceiba petandra & Kapuk & $\sqrt{ }$ & & & & & & \\
\hline 4 & Gerbera manghas & Bintaro & $\sqrt{ }$ & & & & & & \\
\hline 5 & Erythrina crista galli & Dadap merah & & $\sqrt{ }$ & $\sqrt{ }$ & $\sqrt{ }$ & & & \\
\hline 6 & Ficus benjamina & Beringin & $\sqrt{ }$ & & $\sqrt{ }$ & $\sqrt{ }$ & & $\sqrt{ }$ & \\
\hline 7 & Laucaena glauca & Petai cina & & & $\sqrt{ }$ & $\sqrt{ }$ & & & \\
\hline
\end{tabular}


Tabel 35 Nama dan fungsi pohon di Jalan Raya Pajajaran Segmen II (lanjutan)

\begin{tabular}{|c|c|c|c|c|c|c|c|c|c|}
\hline \multirow{2}{*}{ No. } & \multirow{2}{*}{ Nama Ilmiah } & \multirow{2}{*}{ Nama Lokal } & \multicolumn{7}{|c|}{ Fungsi* } \\
\hline & & & 1 & 2 & 3 & 4 & 5 & 6 & 7 \\
\hline 8 & Muthingia calabura & Kersen & & & $\sqrt{ }$ & & & & \\
\hline 9 & Sygyzium oleina & Pucuk merah & & $\sqrt{ }$ & & & & & $\sqrt{ }$ \\
\hline 10 & $\begin{array}{l}\text { Poisonus manihot } \\
\text { esulenta }\end{array}$ & $\begin{array}{l}\text { Singkong } \\
\text { genderuwo }\end{array}$ & $\sqrt{ }$ & & & & & & \\
\hline 11 & Pterocarpus indicus & Angsana & & $\sqrt{ }$ & $\sqrt{ }$ & $\sqrt{ }$ & & $\sqrt{ }$ & \\
\hline (12) & $\begin{array}{l}\text { Ptychosperma } \\
\text { macathurii }\end{array}$ & Palem hijau & $\sqrt{ }$ & $\sqrt{ }$ & & & & & \\
\hline 3 & Swietenia mahogani & Mahoni & & $\sqrt{ }$ & $\sqrt{ }$ & $\sqrt{ }$ & & $\sqrt{ }$ & \\
\hline$\frac{9}{0} 4$ & Tectonia grandis & Jati & $\sqrt{ }$ & & & $\sqrt{ }$ & & & \\
\hline 15 & Terminalia catappa & Ketapang & $\sqrt{ }$ & $\sqrt{ }$ & $\sqrt{ }$ & & & & \\
\hline
\end{tabular}

W Keterangan 1 = estetika, 2 = pengarah jalan, $3=$ peneduh, 4 =penyerap polusi udara, 5 =peredam kebisingan, $6=$ pemecah angin, 7 =border

$\overline{\mathrm{v}}$

Secara keseluruhan, kondisi pohon yang berada di tepi dan median jalan b̄erukuran tinggi. Kondisi ini dapat membentuk kesan dinding bagi pengguna Fâlan sekaligus menjadi pengontrol efek silau dari cahaya matahari. Jarak antar tajuk yang cukup rapat serta kondisi tajuk yang cukup lebar menimbulkan efek Bayangan dan kondisi yang cukup gelap di jalur pejalan kaki. Keberadaan pohon yang berfungsi sebagai peneduh memberikan naungan dan menurunkan suhu Hingkungan sekitar. Suhu udara di bawah bayang-bayang kanopi pohon lebih rendah $8^{\circ} \mathrm{C}$ dari pada di ruang terbuka (Booth 1983). Hal ini membuat pengguna galan merasa nyaman sehingga banyak pengguna jalan yang beristirahat di bahu falan (Gambar 25).

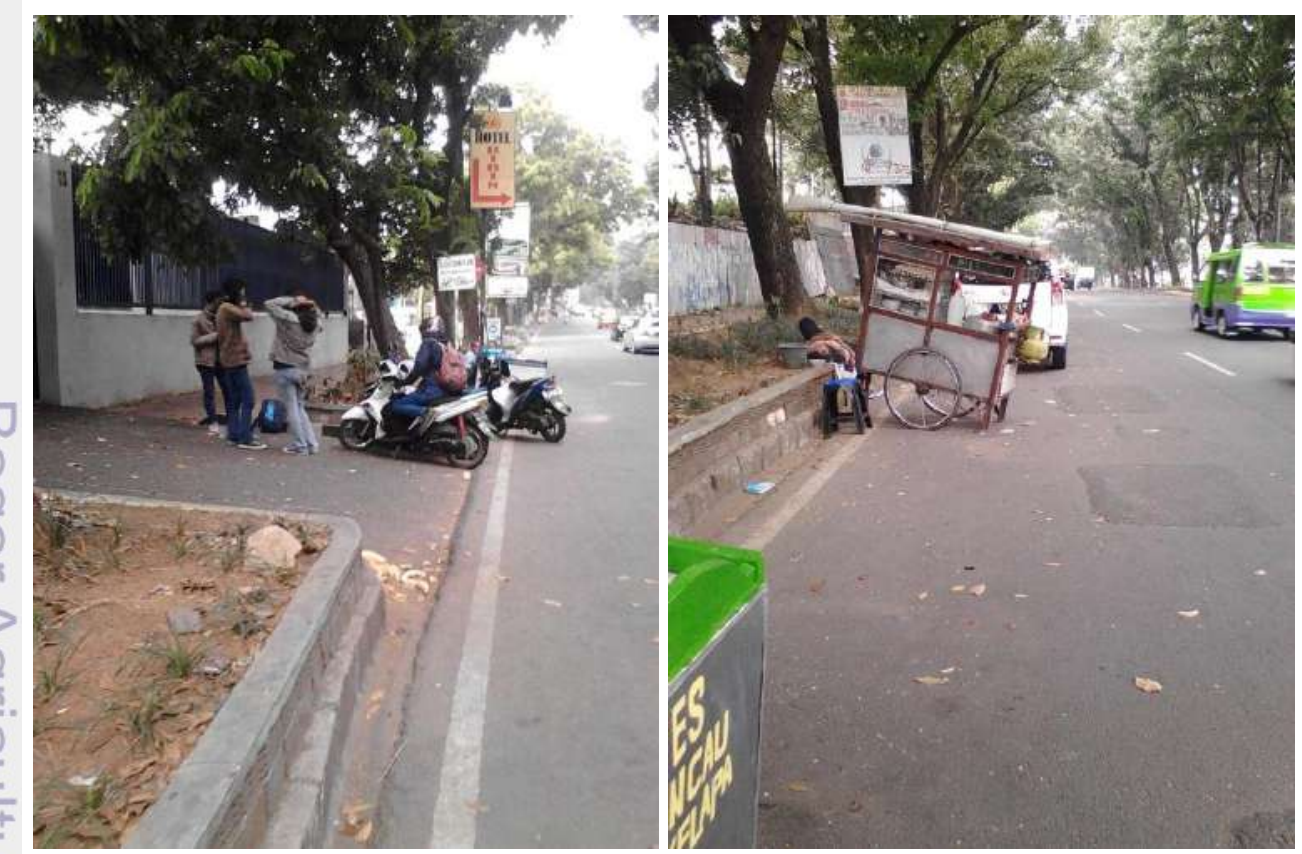

Gambar 25 Pengguna jalan yang beristirahat di bahu jalan Sumber: dokumentasi pribadi 
Vegetasi di jalur hijau Jalan Raya Pajajaran Segmen III juga ditanam secara masal dan bervariasi. Tingkat keragaman tanamannya tidak tinggi. Keragaman vegetasi pada segmen ini tergolong tinggi. Ground cover yang mendominasi median adalah rumput (Axonopus compresus). Perdu yang mendominasi segmen ini adalah lolipop (Pachytachys lutea). Semak yang mendominasi segmen ini adalah spider lily (Hymenocallis spectosa). Penempatan tanaman juga tidak dilakukan secara individu. Pohon yang mendominasi segmen ini adalah pucuk merah (Syzygium oleina).

Pola penanaman vegetasi mengikuti pola jalan. Pohon yang mendominasi adalah pohon berukuran sedang $(6-15 \mathrm{~m})$. Jarak antar tajuk juga cukup rapat sehing $\bar{g}$ a tajuk antarpohon bersinggungan. Kondisi tajuk yang cukup lebar juga menimbulkan efek bayangan dan kondisi yang cukup gelap di jalur pejalan kaki. Pada segmen ini, terdapat pula pengguna jalan yang beristirahat di bahu jalan. Jalur hijau bagian tepi yang berada di sebelah kiri dari arah Botani Square, di dominasi oleh spyder lili (Hymenocallis spectosa). Kondisi menimbulkan kesan monotôn. Fungsi pohon yang mendominasi adalah fungsi pengarah jalan dan peneduh (Tabel 36).

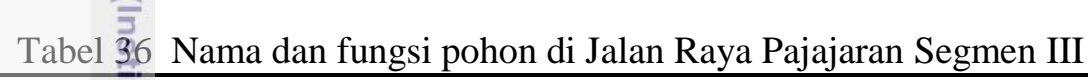

\begin{tabular}{|c|c|c|c|c|c|c|c|c|c|}
\hline \multirow{2}{*}{ No. } & \multirow{2}{*}{ Nama Ilmiah } & \multirow{2}{*}{ Nama Lokal } & \multicolumn{7}{|c|}{ Fungsi* } \\
\hline & & & 1 & 2 & 3 & 4 & 5 & 6 & 7 \\
\hline 1 & Adenanthera pavonia & Saga & & & $\sqrt{ }$ & $\sqrt{ }$ & & & \\
\hline 2 & Bauhinia purpurea & $\begin{array}{l}\text { Bunga kupu- } \\
\text { kupu }\end{array}$ & $\sqrt{ }$ & $\sqrt{ }$ & & $\sqrt{ }$ & & & \\
\hline 3 & Eerbera manghas & Bintaro & $\sqrt{ }$ & & & & & & \\
\hline 4 & Einnamomun burmanii & Kayu manis & $\sqrt{ }$ & $\sqrt{ }$ & & & & & $\sqrt{ }$ \\
\hline 5 & Cupressus papuana & Cemara gembel & & & & $\sqrt{ }$ & $\sqrt{ }$ & & \\
\hline 6 & Erythrina crista galli & Dadap merah & & $\sqrt{ }$ & $\sqrt{ }$ & & & & \\
\hline 7 & Ficus benjamina & Beringin & $\sqrt{ }$ & & $\sqrt{ }$ & $\sqrt{ }$ & & $\sqrt{ }$ & \\
\hline 8 & Muthingia calabura & Kersen & & & $\sqrt{ }$ & & & & \\
\hline 9 & Sygyzium oleina & Pucuk merah & & $\sqrt{ }$ & & & & & $\sqrt{ }$ \\
\hline 10 & Pterocarpus indicus & Angsana & & $\sqrt{ }$ & $\sqrt{ }$ & $\sqrt{ }$ & & $\sqrt{ }$ & \\
\hline 11 & $\begin{array}{l}\text { Ptychosperma } \\
\text { macathurii }\end{array}$ & Palem hijau & $\sqrt{ }$ & $\sqrt{ }$ & & & & & \\
\hline 12 & Swietenia mahogani & Mahoni & & $\sqrt{ }$ & $\sqrt{ }$ & $\sqrt{ }$ & & $\sqrt{ }$ & \\
\hline
\end{tabular}

*Keterangan 1 = estetika, 2 = pengarah jalan, 3 = peneduh, 4 =penyerap polusi udara, 5 =peredam kebisingan, 6 = pemecah angin, 7 =border

Vegetasi di jalur hijau Jalan Otto Iskandardinata didominasi oleh Kelapa Sawit (Elais gunensis). Vegetasi ditanam secara masal dengan pola penanaman mengikuti pola jalan dengan tingkat keragaman tanaman yang tidak tinggi. Fungsi pohoñyang mendominasi adalah fungsi pengarah jalan (Tabel 37). 
Tabel 37 Nama dan fungsi pohon di Jalan Otto Iskandardinata

\begin{tabular}{llllllllll}
\hline \multirow{2}{*}{ No. } & \multirow{2}{*}{ Nama Ilmiah } & \multirow{2}{*}{ Nama Lokal } & \multicolumn{7}{c}{ Fungsi* } \\
\cline { 3 - 8 } & & & 1 & 2 & 3 & 4 & 5 & 6 & 7 \\
\hline 1 & Araucaria heterophylla & Cemara norflok & $\sqrt{ }$ & $\sqrt{ }$ & $\sqrt{ }$ & $\sqrt{ }$ & $\sqrt{ }$ & $\sqrt{ }$ & $\sqrt{ }$ \\
2 & Elais gunensis & Kelapa sawit & & $\sqrt{ }$ & & & & & \\
3 & Roystonia regia & Palem raja & & $\sqrt{ }$ & & & & & \\
\hline
\end{tabular}

*Keterangan 1 = estetika, 2 = pengarah jalan, 3 = peneduh, 4 =penyerap polusi udara, 5 =peredam kebisingan, $6=$ pemecah angin, $7=$ border

I Secara umum, pola penanaman vegetasi di Jalan Bina Marga dilakukan mengikuti pola jalan dengan tingkat keragaman yang cukup tinggi di taman sudut. Fegetasi di taman sudut Jalan Bina Marga didominasi oleh ground cover, sedangkan vegetasi yang mendominasi jalur hijau tepi jalan adalah jenis pohon. छegetasi jenis semak, perdu, dan ground cover umumnya tidak diletakkan secara individu. Ground cover yang mendominasi taman sudut adalah brokoli (Olenacea $\overline{\mathrm{Sp}}$.) Semak yang mendominasi adalah iris bunga kuning (Neomartea longifolia). Rerdu yang mendominasi adalah alokasia (Alocasia macrorrhiza). Kondisi jalur hijau disajikan pada Gambar 26.

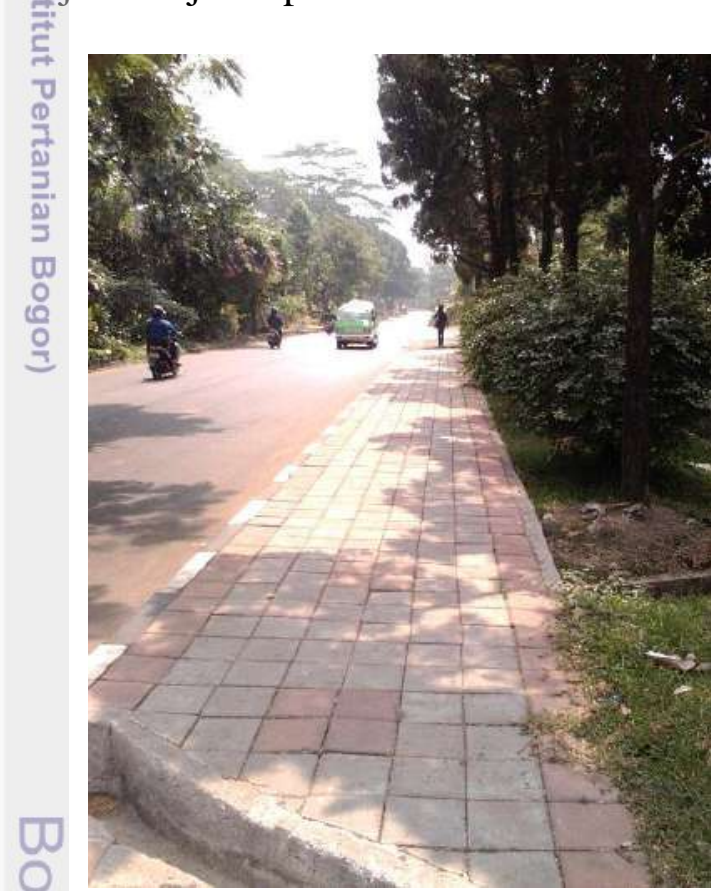

(a)

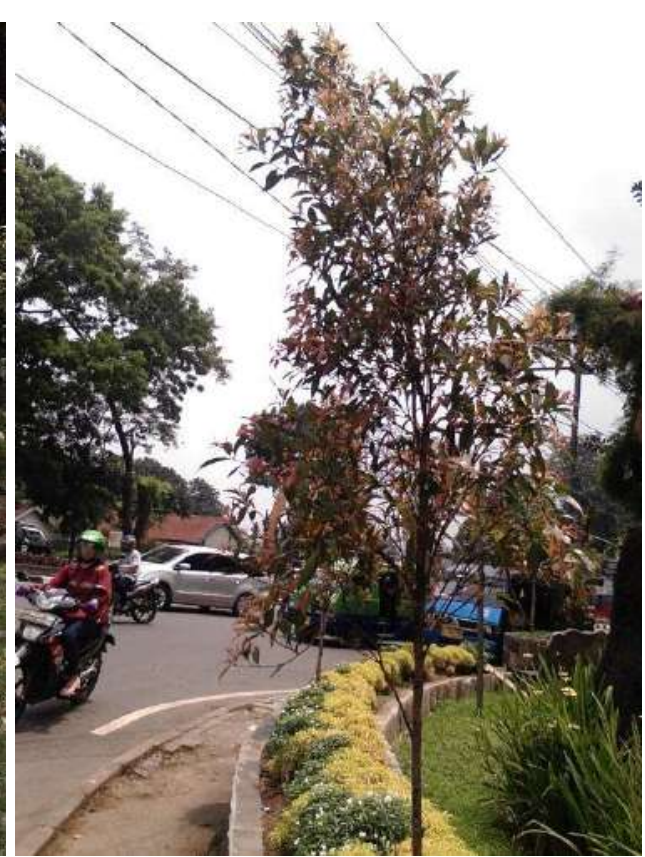

(b)

Gambar 26 Kondisi jalur hijau jalan di (a) tepi jalan dan (b) taman sudut Sumber: dokumentasi pribadi

Secara keseluruhan, penanaman vegetasi sudah sesuai dengan standar, Tetapi terdapat tanaman buah seperti pepaya (Caricas papaya) dan pohon pisang FMusa acuminata) di dalam tapak. Hal ini bertentangan dengan standar penanaman di tepi jalan. Perdu nusa indah (Mussaenda sp.) yang terdapat dalam tapak dapat menyerap NO. Tanaman ini menambah jumlah fungsi tanaman yang dapat menyerap polusi. Warna cerah dari brokoli (Oleanea sp.) dan iris bunga 
kuning (Neomartea longifolia) memberikan efek riang, hangat dan tenang (Gambar 27).

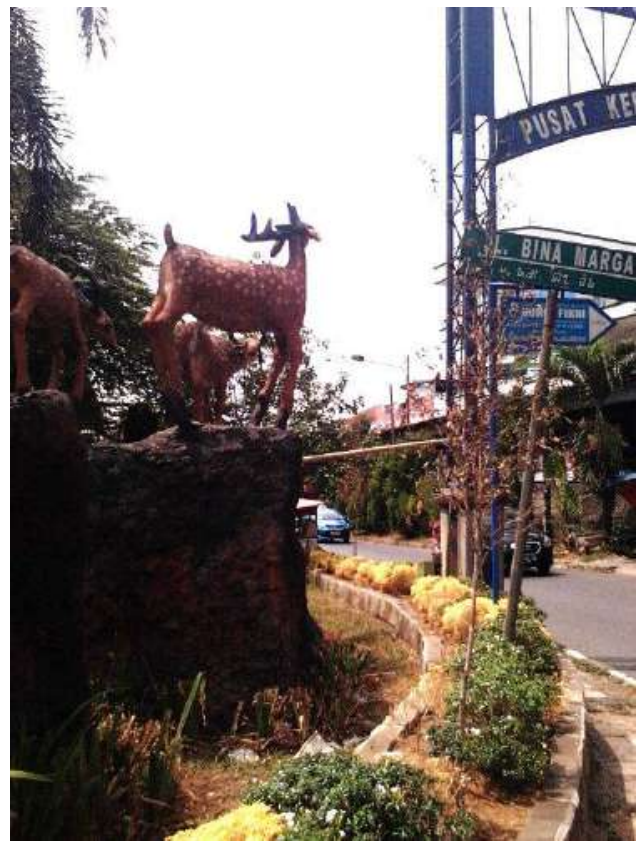

Gambar 27 Kombinasi warna cerah dari semak dan ground cover Sumber: dokumentasi pribadi

Pohon yang mendominasi jalur hijau bagian tepi dari Jalan Bina Marga adalahmahoni (Swietenia mahogani) dan pohon pisang (Musa acuminata). Fungsi pohonfyang mendominasi adalah fungsi pengarah jalan (Tabel 38).

Tabel 38 Nama dan fungsi pohon di Jalan Bina Marga

\begin{tabular}{|c|c|c|c|c|c|c|c|c|c|}
\hline \multirow{2}{*}{ No. } & \multirow{2}{*}{ Nama Ilmiah } & \multirow{2}{*}{ Nama Lokal } & \multicolumn{7}{|c|}{ Fungsi* } \\
\hline & & & 1 & 2 & 3 & 4 & 5 & 6 & 7 \\
\hline 1 & Agathis dammara & Damar & $\sqrt{ }$ & $\sqrt{ }$ & & $\sqrt{ }$ & & & $\sqrt{ }$ \\
\hline 2 & Araucaria heterophylla & Cemara norflok & $\sqrt{ }$ & $\sqrt{ }$ & $\sqrt{ }$ & $\sqrt{ }$ & $\sqrt{ }$ & $\sqrt{ }$ & $\sqrt{ }$ \\
\hline 3 & Carica papaya & Pepaya & $\sqrt{ }$ & & & & & & \\
\hline 4 & Casuarina sumatrana & Cemara sumatra & & & $\sqrt{ }$ & & $\sqrt{ }$ & & \\
\hline 5 & Cinnamomun burmanii & Kayu manis & $\sqrt{ }$ & $\sqrt{ }$ & & & & & $\sqrt{ }$ \\
\hline 6 & Cocos nucifera & Kelapa & & $\sqrt{ }$ & & & & & \\
\hline 7 & $\begin{array}{l}\text { Filicium decipirens } \\
\text { Thw. }\end{array}$ & Kere payung & & $\sqrt{ }$ & $\sqrt{ }$ & & & $\sqrt{ }$ & \\
\hline 8 & Musa acuminata & Pohon pisang & $\sqrt{ }$ & & & & & & \\
\hline 9 & OPlumeria sp. & Kamboja & $\sqrt{ }$ & $\sqrt{ }$ & & & & & \\
\hline 10 & Polyalthia longifolia & Glodogan tiang & & $\sqrt{ }$ & & $\sqrt{ }$ & & $\sqrt{ }$ & $\sqrt{ }$ \\
\hline 11 & Pterocarpus indicus & Angsana & & $\sqrt{ }$ & $\sqrt{ }$ & $\sqrt{ }$ & & $\sqrt{ }$ & \\
\hline 12 & Swietenia mahogani & Mahoni & & $\sqrt{ }$ & $\sqrt{ }$ & $\sqrt{ }$ & & $\sqrt{ }$ & \\
\hline 13 & 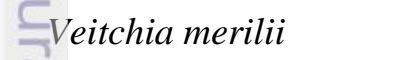 & Palem putri & $\sqrt{ }$ & $\sqrt{ }$ & & & & & \\
\hline
\end{tabular}


Tabel 38 Nama dan fungsi pohon di Jalan Bina Marga (lanjutan)

\begin{tabular}{|c|c|c|c|c|c|c|c|c|c|}
\hline \multirow{2}{*}{ No. } & \multirow{2}{*}{ Nama Ilmiah } & \multirow{2}{*}{ Nama Lokal } & \multicolumn{7}{|c|}{ Fungsi* } \\
\hline & & & 1 & 2 & 3 & 4 & 5 & 6 & 7 \\
\hline 14 & Wodyetia bifurcata & Palem ekor tupai & & $\sqrt{ }$ & & & & & \\
\hline
\end{tabular}

Vegetasi berjenis pohon yang berada di median Tol Jagorawi ditempatkan dengan pola linear dengan jarak yang berjauhan. Vegetasi jenis pohon didominasi oleh tabebuya bunga kuning (Tabebuia chrysanta). Terdapat beberapa diantaranya yang ditanam berjauhan. Tanaman yang ditempatkan dalam median atau tepi jalan tol seharusnya ditanam secara masal dengan jarak tanam rapat. Jarak antarpohon di Tol Jagorawi cukup jauh, sedangkan vegetasi berjenis perdu, semak, dan ground cover sebagian besar ditanam secara masal.

Tanaman yang ditempatkan di median tol seharusnya berfungsi meredam kebisingan, mereduksi polusi dan memecah angin. Menurut Lerner dalam Hidayat (2010), untuk mengoptimalkan fungsi peredam kebisingan, tanaman di jalur hijau 商lan tol seharusnya ditanam dengan konfigurasi tanaman setebal 25 kaki atau Sebesar 8 meter. Selain itu, tanaman yang ditanam sebaiknya merupakan tanaman É Eerdaun runcing. Tanaman berdaun runcing dapat menurunkan level kebisingan lebih tinggi. Tanaman yang berfungsi menyerap polusi udara hanya phoenix berdaun halus (Phoenix roebeleni). Tidak terdapat pohon yang berfungsi meredam kebisingan. Fungsi pohon yang mendominasi adalah fungsi estetika (Tabel 39). ए丁

\abel 39 Nama dan fungsi pohon di Tol Jagorawi

\begin{tabular}{|c|c|c|c|c|c|c|c|c|c|}
\hline \multirow{2}{*}{ No. } & \multirow{2}{*}{ Nama Ilmiah } & \multirow{2}{*}{ Nama Lokal } & \multicolumn{7}{|c|}{ Fungsi* } \\
\hline & & & 1 & 2 & 3 & 4 & 5 & 6 & 7 \\
\hline 1 & Phoenix roebelenii & $\begin{array}{l}\text { Phoenix daun } \\
\text { halus }\end{array}$ & $\sqrt{ }$ & & & $\sqrt{ }$ & & & \\
\hline 2 & $\begin{array}{l}\text { Ptychosperma } \\
\text { macathurii }\end{array}$ & Palem hijau & $\sqrt{ }$ & $\sqrt{ }$ & & & & & \\
\hline 3 & Tabebuya chrysanta & $\begin{array}{l}\text { Tabebuya bunga } \\
\text { kuning }\end{array}$ & & & & & & & \\
\hline 4 & Veitchia merilii & Palem putri & $\sqrt{ }$ & $\sqrt{ }$ & & & & & \\
\hline 5 & Wodyetia bifurcata & Palem ekor tupai & & $\sqrt{ }$ & & & & & \\
\hline 6 & Cocos nucifera & Kelapa & $\sqrt{ }$ & & & & & & \\
\hline
\end{tabular}

*Keterangan 1 = estetika, 2 = pengarah jalan, 3 = peneduh, 4 =penyerap polusi udara, 5 =peredam kebisingan, 6 = pemecah angin, 7 =border

Ground cover yang mendominasi adalah rumput (Axonopus compressus). Semak yang mendominasi adalah kana (Canna sp.). Warna kuning dari bunga Tabebuya (Tabebuia chrysanta) dan warna merah dari simbang darah (Iresine herbstii) menambah nilai estetika dan memberikan kesan hangat di median. Selain ittl, warna merah dari simbang darah (Iresine herbstii) memberikan kesan kontras terhadap tanaman berdaun hijau yang ada di sekitarnya (Gambar 28). 


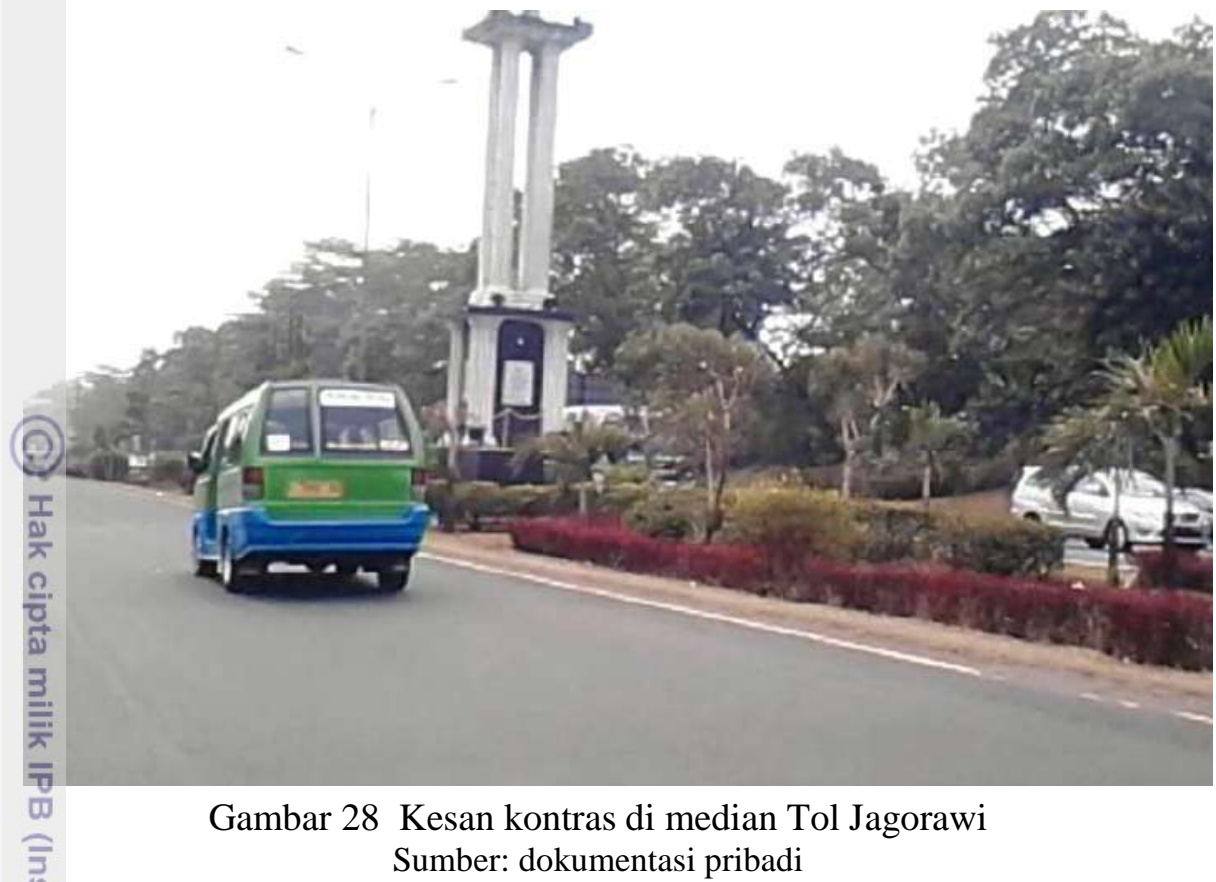

Vegetasi yang mendominasi di Jalan Padi adalah jenis pohon. Jarak antarpōhon cukup jauh dengan pola penanaman linear. Pohon bintaro (Cerbera manghas) dan pohon mengkudu (Morinda citrifolia) merupakan tanaman buah, seharusnya tidak ditempatkan di tepi jalan. Vegetasi berjenis perdu, semak, dan ground cover di tapak ditanam dan dipelihara oleh masyarakat sekitar tapak. Perduo semak, dan ground cover ditanam secara berjauhan, sehingga tidak tertangkap oleh pejalan kaki dan pengemudi kendaraan. Fungsi pohon yang mendominasi adalah fungsi estetika, pengarah jalan dan border (Tabel 40).

Tabel 40 Nama dan fungsi pohon di Jalan Padi

\begin{tabular}{clllllllll}
\hline & \multirow{2}{*}{ No. } & \multirow{2}{*}{ Nama Ilmiah } & \multirow{2}{*}{ Nama Lokal } & \multicolumn{7}{c}{ Fungsi* } \\
\cline { 3 - 9 } & & & 1 & 2 & 3 & 4 & 5 & 6 & 7 \\
\hline 1 & Cerbera manghas & Bintaro & $\sqrt{ }$ & & & & & \\
2 & Cinnamomun burmanii & Kayu manis & $\sqrt{ }$ & $\sqrt{ }$ & & & & & $\sqrt{ }$ \\
3 & Ficus benjamina & Beringin & $\sqrt{ }$ & & $\sqrt{ }$ & $\sqrt{ }$ & & $\sqrt{ }$ & \\
4 & Morinda citrifolia & Mengkudu & & & $\sqrt{ }$ & & & & \\
5 & Sygyzium oleina & Pucuk merah & & $\sqrt{ }$ & & & & & $\sqrt{ }$ \\
6 & OPolyalthia fragrans & Glodogan bulat & & $\sqrt{ }$ & & & $\sqrt{ }$ & $\sqrt{ }$ & $\sqrt{ }$ \\
7 & OSamanea saman & Ki hujan & & & $\sqrt{ }$ & $\sqrt{ }$ & & & \\
\hline
\end{tabular}

*Keterangan $1=$ estetika, $2=$ pengarah jalan, $3=$ peneduh, $4=$ penyerap polusi udara, $5=$ peredam kebisingan, $6=$ pemecah angin, $7=$ border

Kondisi tapak cukup panas karena tidak ada pohon peneduh di salah satu sisi jatur hijau jalan. Kondisi di persimpangan Jalan Padi dengan Jalan Pakuan dan Jalan@Bina Marga tergolong nyaman karena keberadaan pohon ki hujan (Samanea saman,. Pohon tersebut juga menjadi point of interest dan identitas dari tapak (Gambar 29). 


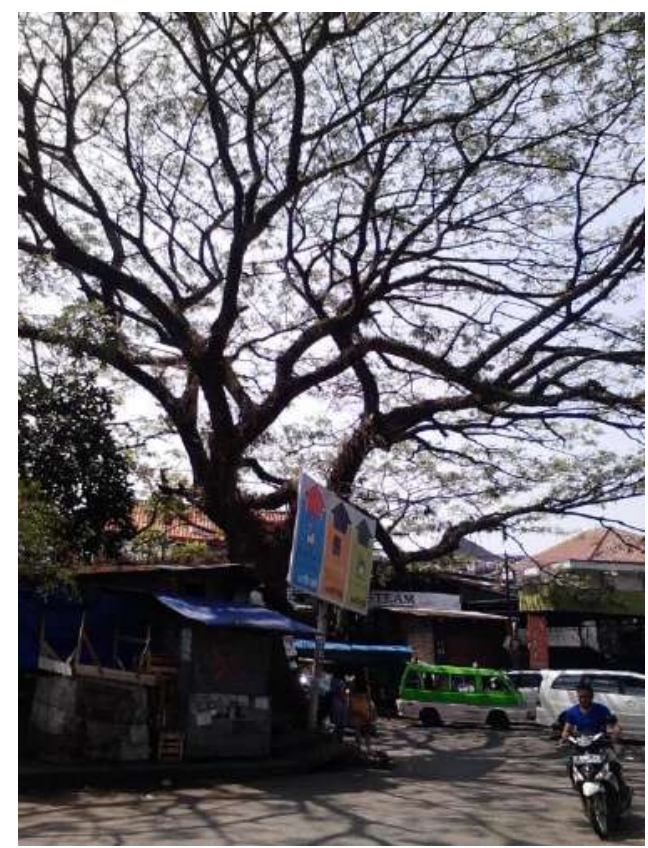

Gambar 29 Pohon ki hujan (Samanea saman) di Jalan Padi Sumber: dokumentasi pribadi

Jarak antarpohon yang berada di tepi Jalan Pakuan berbeda-beda. Jarak antarpohon di tepi jalan sebelah kanan (dari arah persimpangan Jalan Pajajaran) cukup jauh, sedangkan jarak antarpohon di sisi kiri jalan tergolong cukup rapat. Bohon bunga kupu-kupu (Bauhinia purpurea Linn.) yang berada di median jalan Bhenjadi point of interest pada tapak (Gambar 30).

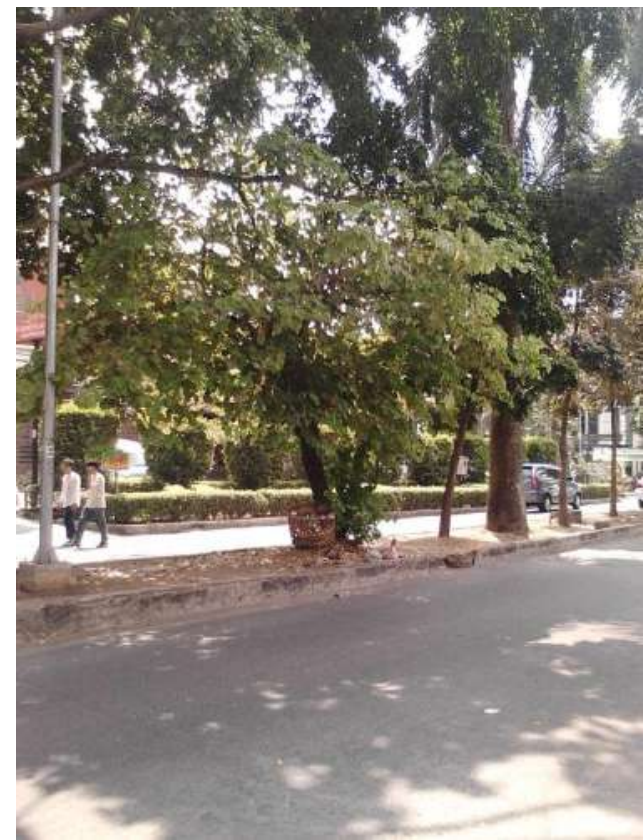

Gambar 30 Pohon bunga kupu-kupu (Bauhinia purpurea Linn.) Sumber: dokumentasi pribadi 
Pohon di median Jalan Pakuan didominasi oleh pohon tua. Pohon di bagian median jalan ditanam secara linear dengan jarak yang cukup rapat. Hal ini menimbulkan kesan mengarahkan pengguna kendaraan bermotor. Jarak tanam antarpohon di median yang tergolong rapat juga membentuk kesan dinding dan kaku (Gambar 31).
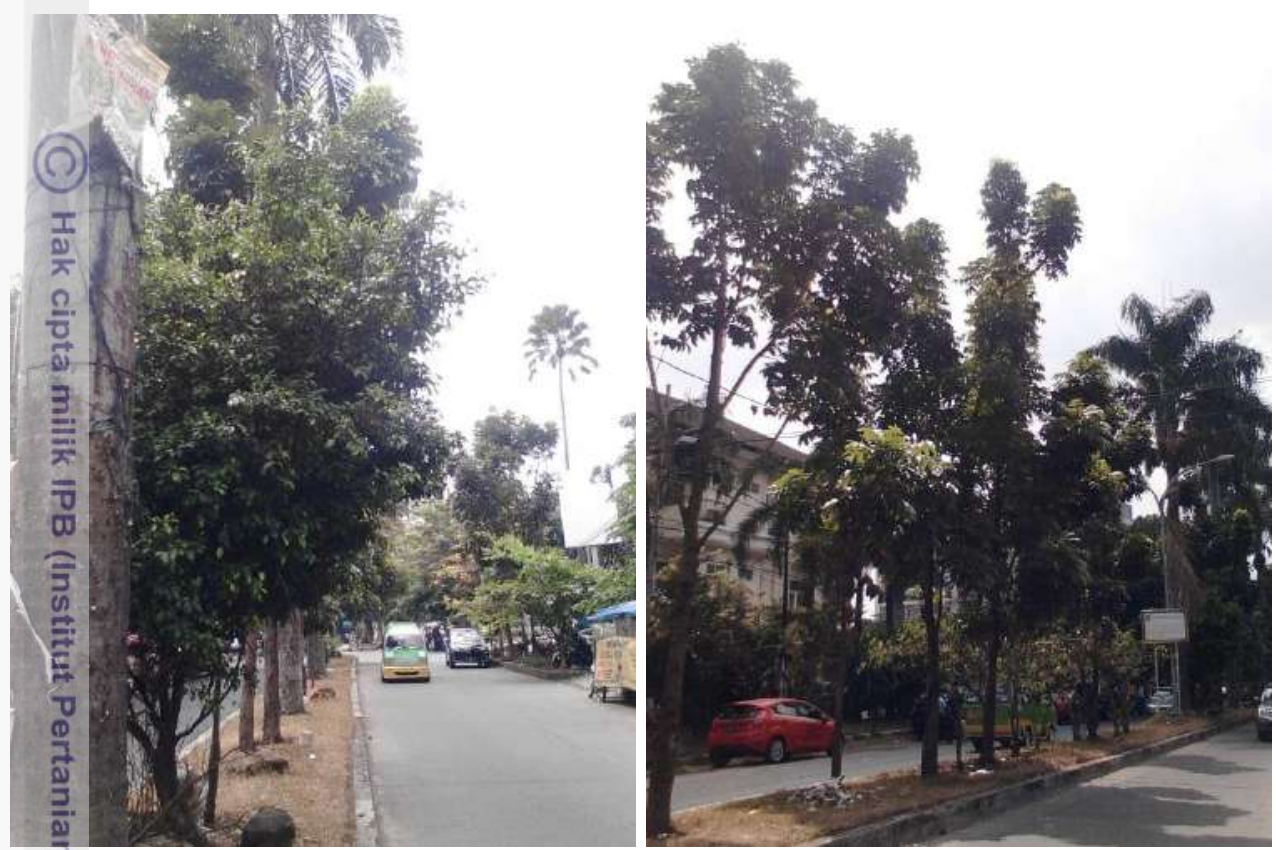

Tombar 31 Jarak tanam yang rapat di median memberi kesan dinding Sumber: dokumentasi pribadi

Pohon yang mendominasi di Jalan Pakuan adalah mahoni (Swietenia mahogani). Tidak terdapat pohon dengan fungsi peredam kebisingan dan border pada tapak. Fungsi pohon yang mendominasi adalah fungsi pengarah jalan, peneduh dan penyerap polusi udara (Tabel 41).

Tabel 41 Nama dan fungsi pohon di Jalan Pakuan

\begin{tabular}{|c|c|c|c|c|c|c|c|c|c|}
\hline \multirow{2}{*}{ No. } & \multirow{2}{*}{ Nama Ilmiah } & \multirow{2}{*}{ Nama Lokal } & \multicolumn{7}{|c|}{ Fungsi* } \\
\hline & & & 1 & 2 & 3 & 4 & 5 & 6 & 7 \\
\hline 1 & Bauhinia purpurea & $\begin{array}{l}\text { Bunga kupu- } \\
\text { kupu }\end{array}$ & $\sqrt{ }$ & $\sqrt{ }$ & & $\sqrt{ }$ & & & \\
\hline 2 & Erythrina crista galli & Dadap merah & & $\sqrt{ }$ & $\sqrt{ }$ & $\sqrt{ }$ & & & \\
\hline 3 & Ficus benjamina & Beringin & $\sqrt{ }$ & & $\sqrt{ }$ & $\sqrt{ }$ & & $\sqrt{ }$ & \\
\hline 4 & Muthingia calabura & Kersen & & & $\sqrt{ }$ & & & & \\
\hline 5 & Pterocarpus indicus & Angsana & & $\sqrt{ }$ & $\sqrt{ }$ & $\sqrt{ }$ & & $\sqrt{ }$ & \\
\hline 7 & Swietenia mahogani & Mahoni & & $\sqrt{ }$ & $\sqrt{ }$ & $\sqrt{ }$ & & $\sqrt{ }$ & \\
\hline
\end{tabular}

*Keterangan 1 = estetika, 2 = pengarah jalan, 3 = peneduh, 4 =penyerap polusi udara, 5 =peredam kebisingan, 6 = pemecah angin, 7 =border 
Analisis Preferensi Pengguna

Berikut adalah hasil preferensi pengguna jalan di jalur pejalan kaki dan jalur kendaraan bermotor.

\section{Preferensi Pejalan Kaki}

Preferensi pejalan kaki terhadap kelima aspek di jalur hijau Jalan Raya Segmen I secara keseluruhan tergolong cukup. Sebagian besar responden pejalan kaki menyatakan cukup bersih, karena di beberapa titik lokasi masih terdapat tumpukan sampah di jalur pejalan kaki dan drainase. Sampah ini berasal dari dedaunan kering pepohonan, dari pengguna jalan, dan pedagang kaki lima yang 丽embuang sampah tidak pada tempatnya. Terkait aspek keindahan, sebanyak $39 \%$ responden menyatakan indah. Banyaknya sampah di drainase, jalur pejalan kaki, dan di jalur hijau mengurangi nilai estetika. Grafik preferensi pengguna terkait lima aspek disajikan pada Gambar 32.

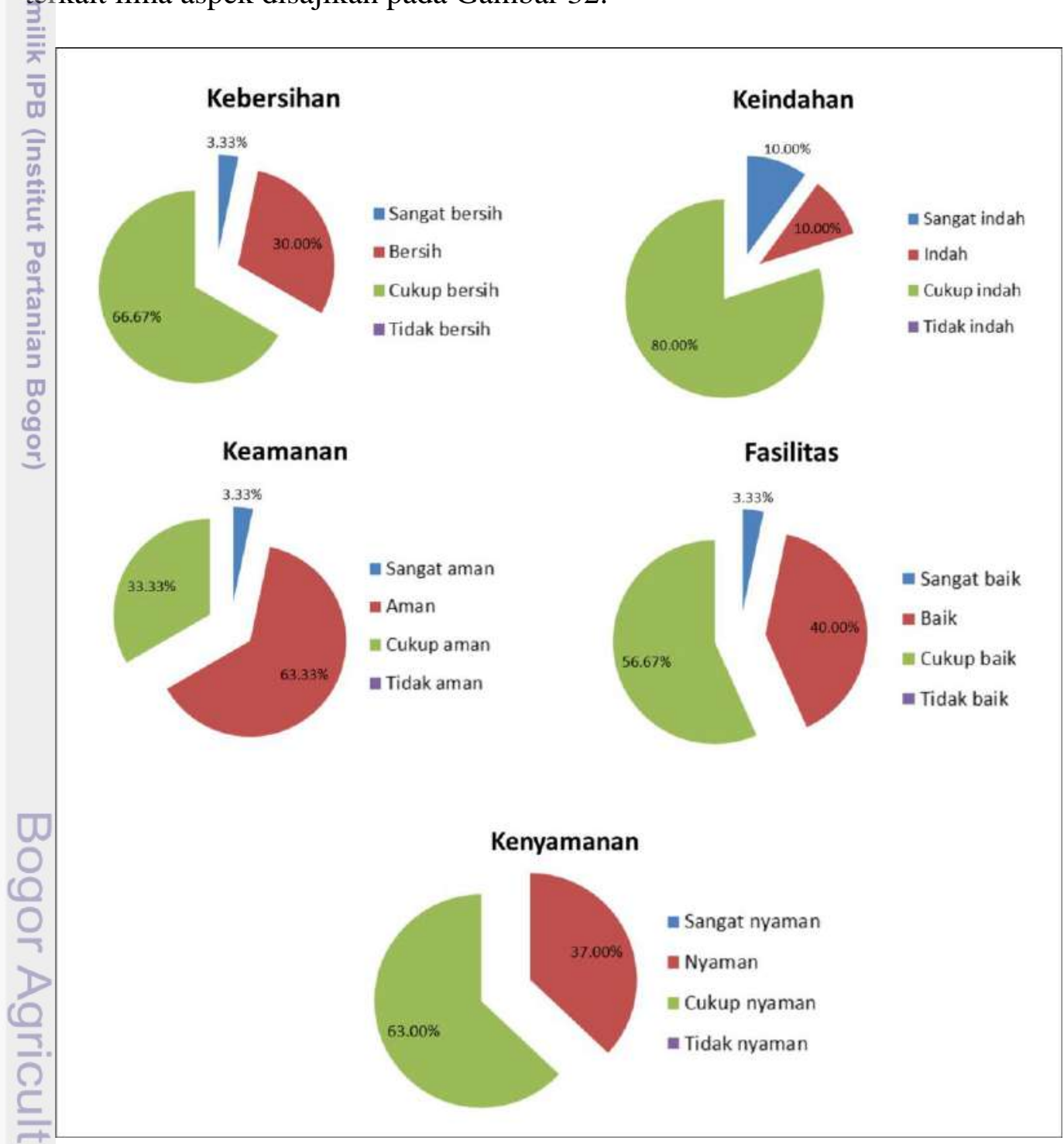

Gambar 32 Preferensi pejalan kaki mengenai kelima aspek di Jalan Raya Pajajaran Segmen I 
Preferensi pejalan kaki terhadap kelima aspek di jalur hijau Jalan Raya Segmen II secara keseluruhan tergolong cukup baik. Sebagian besar responden memberi penilaian dengan kategori cukup untuk semua aspek. Grafik preferensi pengguna disajikan pada Gambar 33.

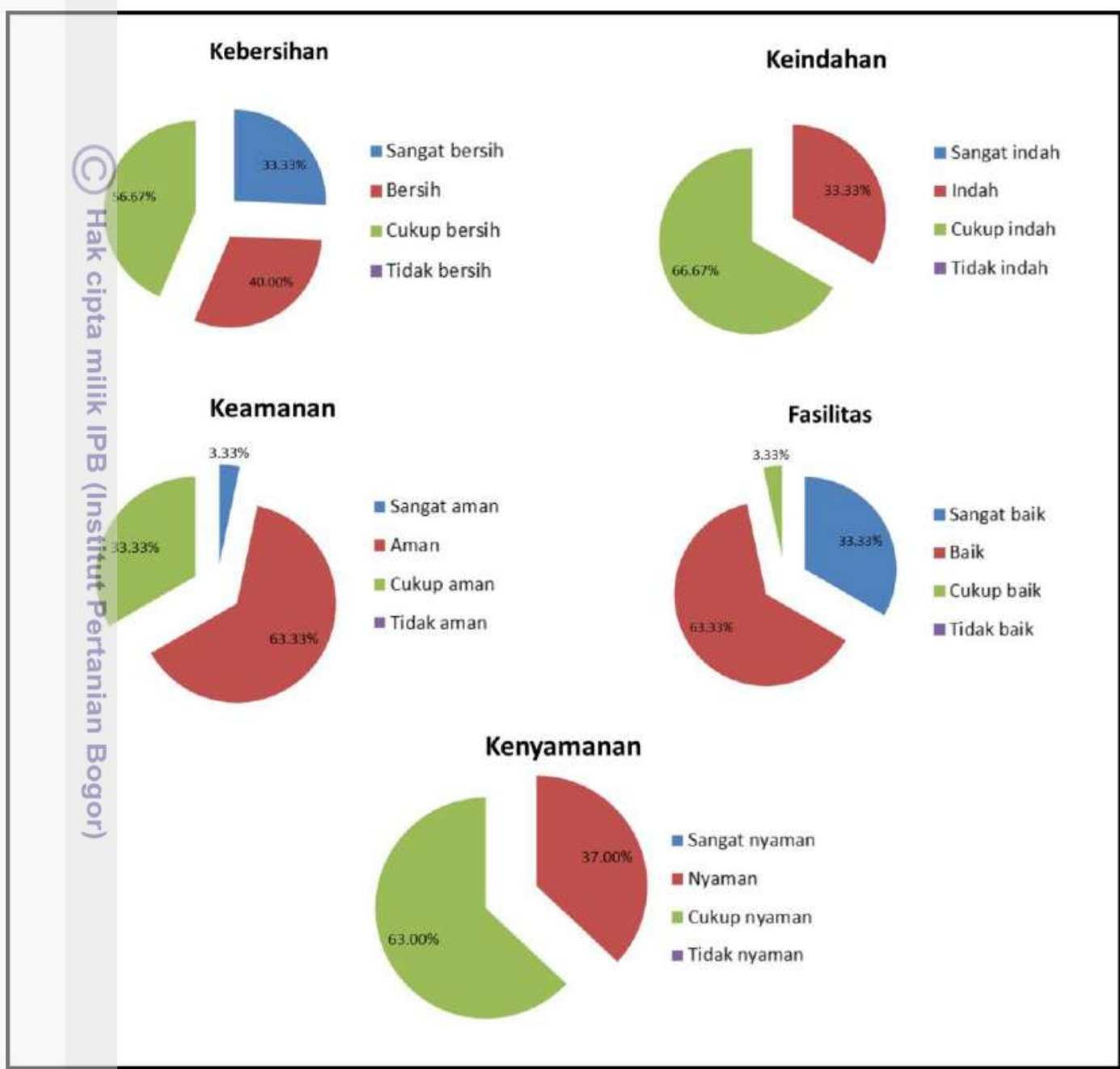

Gambar 33 Preferensi pejalan kaki mengenai kelima aspek di Jalan Raya Pajajaran Segmen II

Dreferensi pejalan kaki terhadap kelima aspek di jalur hijau Jalan Raya Segmen III secara keseluruhan cukup baik. Sebagian besar responden memberi penilaian dengan kategori cukup untuk semua aspek. Keberadaan sampah dan tanaman yang tidak dipangkas di beberapa titik lokasi membuat penilaian terhadap keamanan, keindahan, dan kenyamanan berkurang (Gambar 34). Grafik preferensi pengguna disajikan pada Gambar 35. 


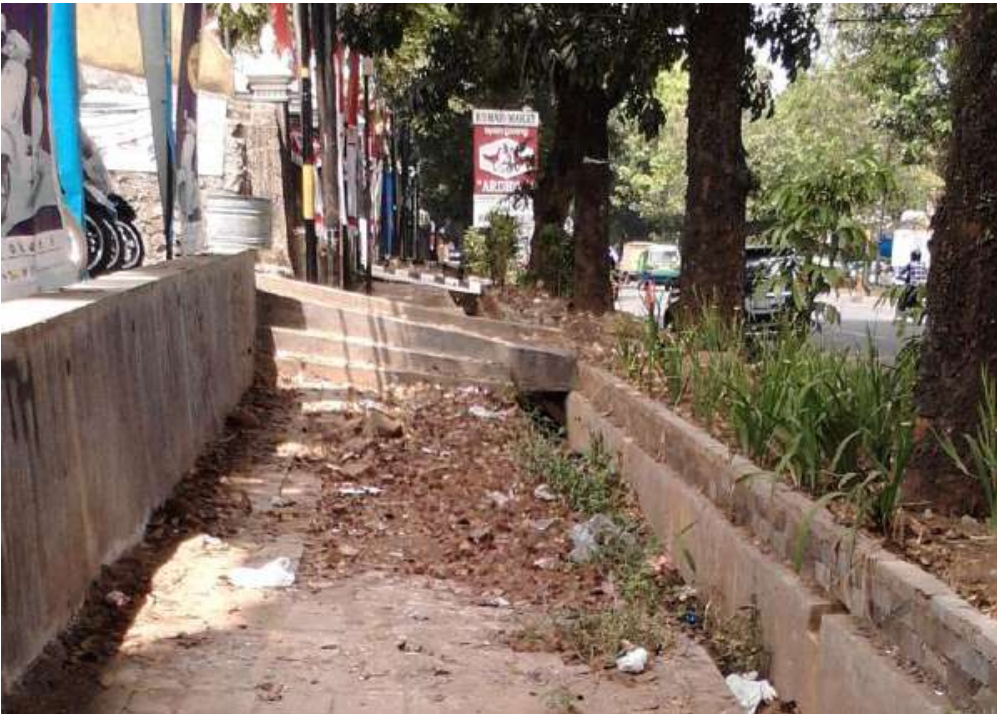

Gambar 34 Keberadaan sampah pada tapak

Sumber: dokumentasi pribadi

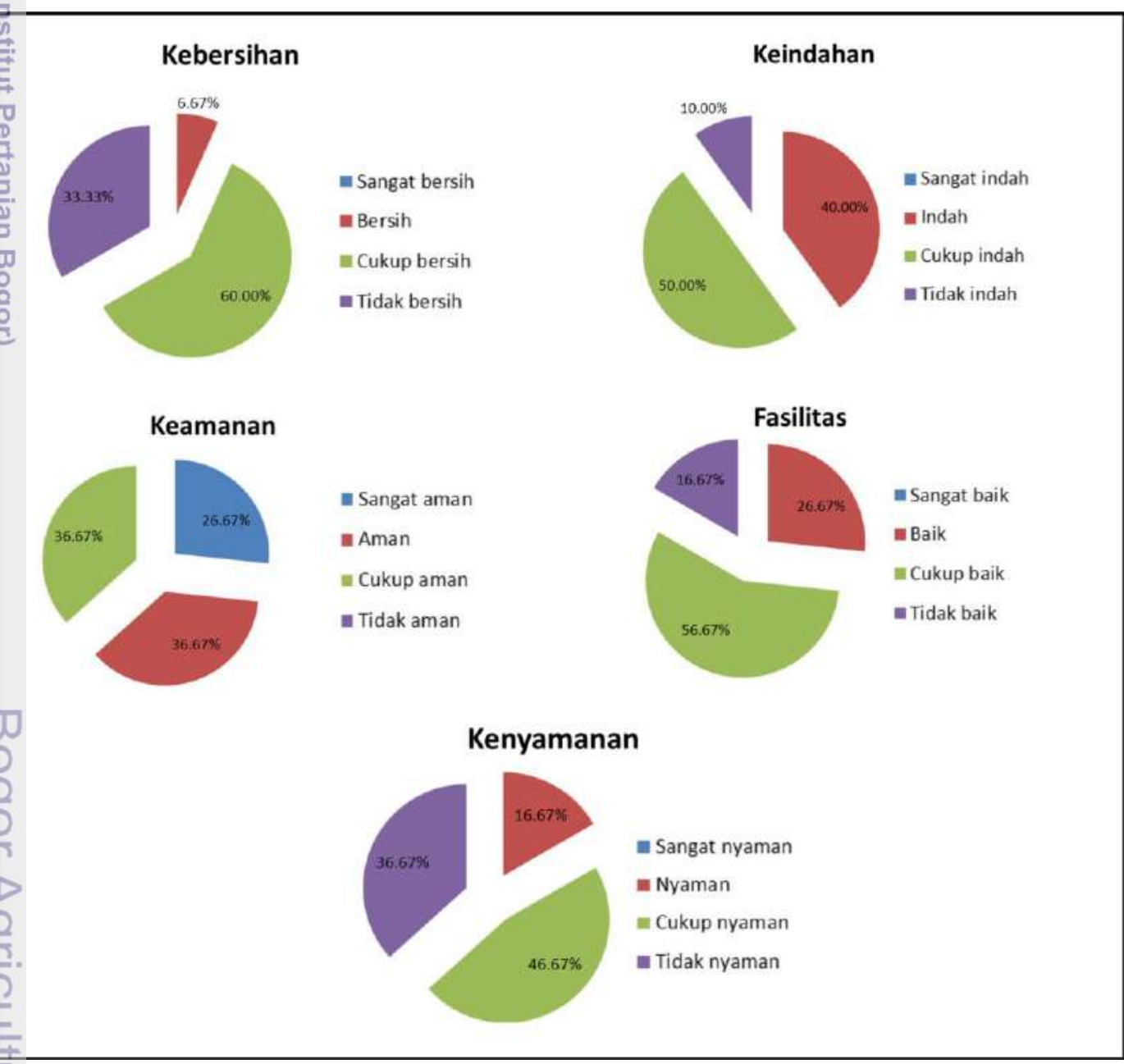

Gambar 35 Preferensi pejalan kaki mengenai kelima aspek di Jalan Raya Pajajaran Segmen III 
Preferensi pejalan kaki di Jalan Otto Iskandardinata terkait kelima aspek tergolong cukup. Berdasarkan hasil wawancara dan pengamatan lapang, di beberapa titik lokasi masih terdapat tumpukan sampah di jalur pejalan kaki, jalur hijau, dan drainase. Sampah ini berasal dari tanaman. Keberadaan sampah yang menumpuk mempengaruhi aspek keindahan. Grafik preferensi pengguna disajikan pada Gambar 36.

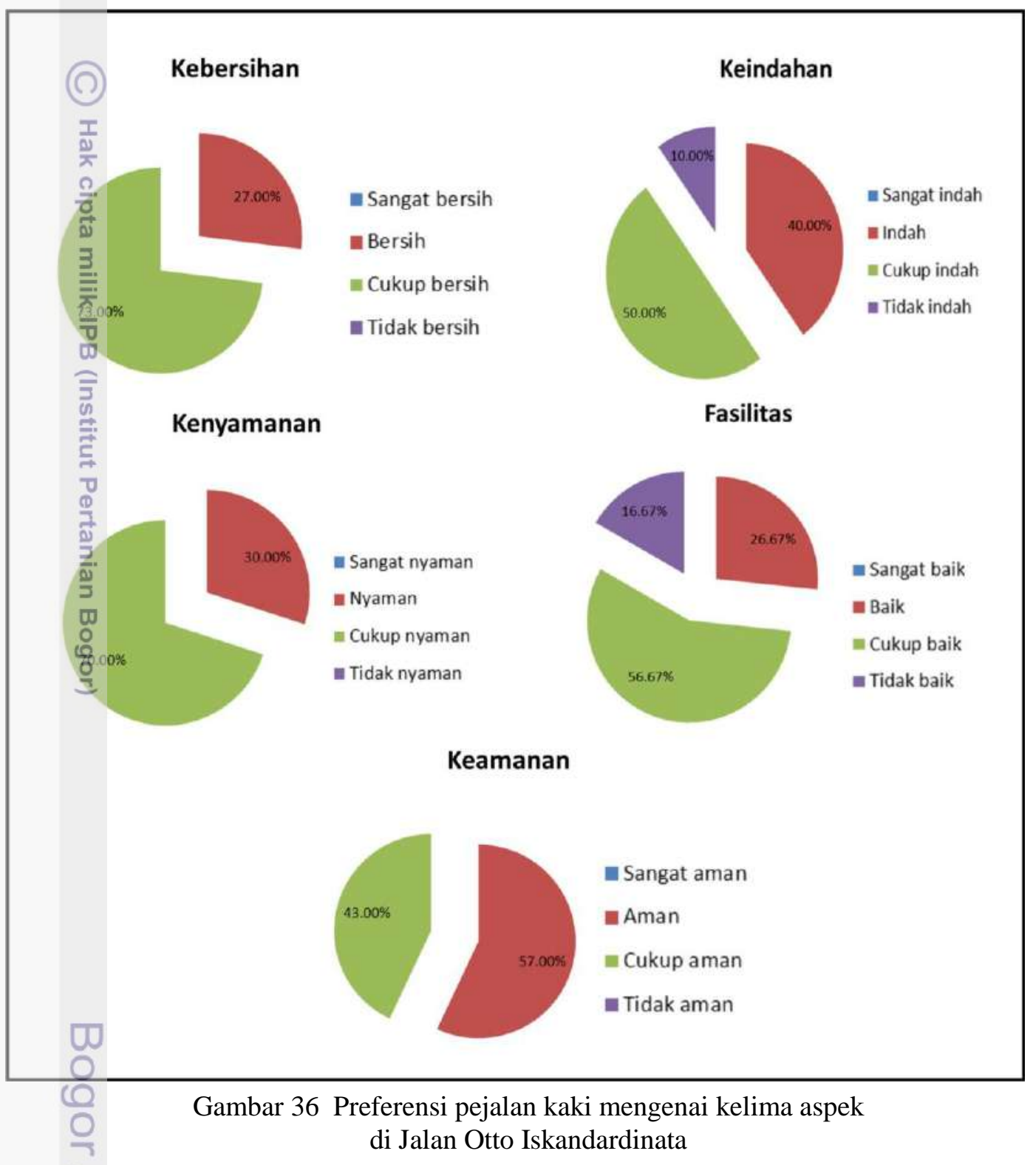

Preferensi pejalan kaki di Jalan Bina Marga terkait kelima aspek tergolong cukup. Terkait aspek keindahan, sebanyak 30\% responden menyatakan sangat inidah. Hal ini disebabkan oleh keragaman tanaman yang dijual oleh para pedagang tanaman hias di Jalan Bina Marga. Grafik preferensi pengguna disajikan pada Gambar 37. 


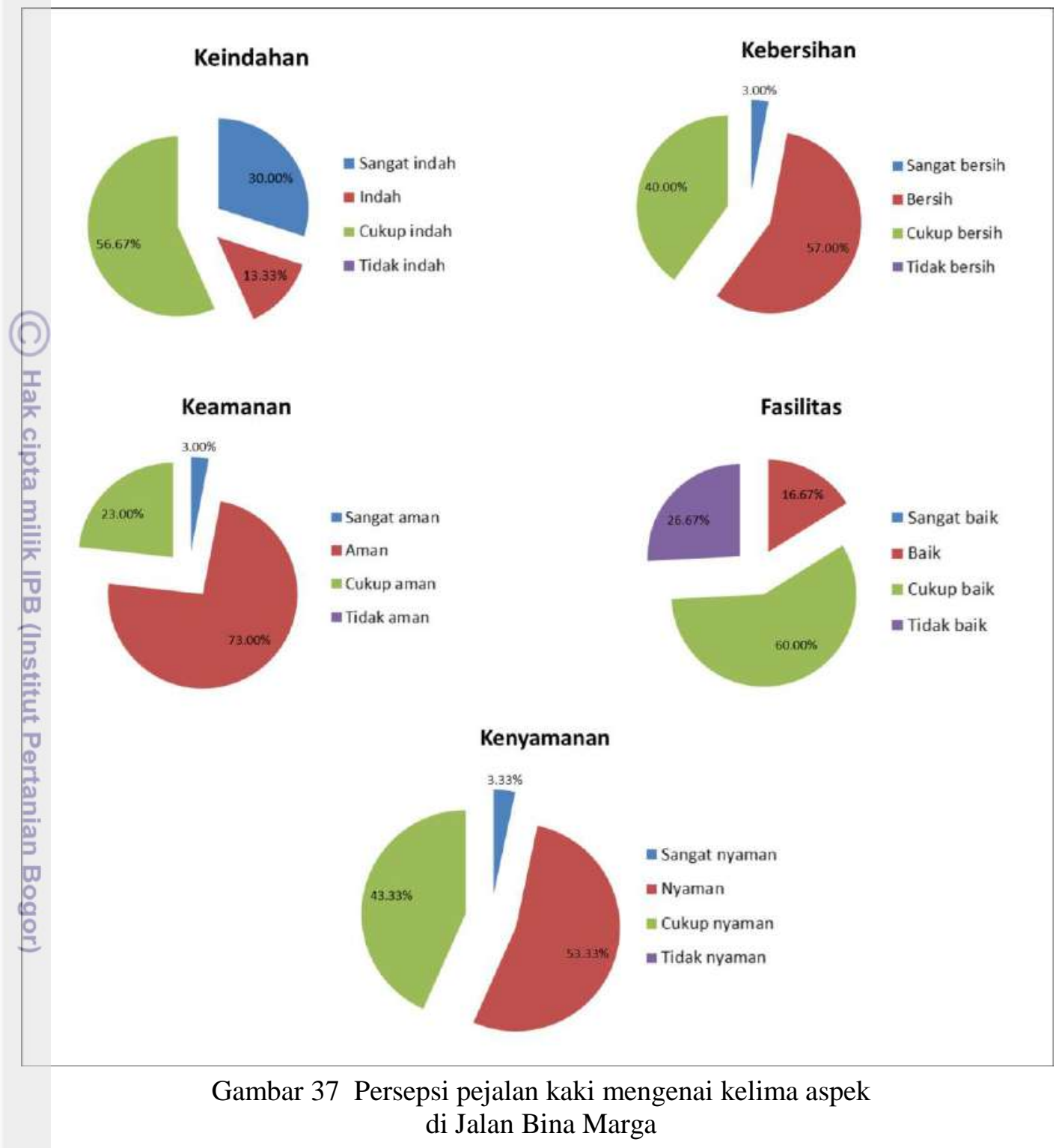

Preferensi pejalan kaki terhadap di kelima Jalan Padi secara keseluruhan cukup baik. Sebanyak $27 \%$ responden memberikan penilaian tidak bersih. Hal ini dikarenakan tumpukan sampah di sekitar tempat sampah. Jalur pejalan kaki pada tapak tidak sepenuhnya dapat digunakan oleh pengguna jalan karena keberadaan pedagang kaki lima. Oleh sebab itu, pengguna jalan terkadang harus berjalan di jalur pengguna kendaraan bermotor. Walaupun demikian, sebagian besar responden merasa aman saat melintas di Jalan Padi. Grafik preferensi pengguna disajikan pada Gambar 38. 
Kebersihan

Keindahan

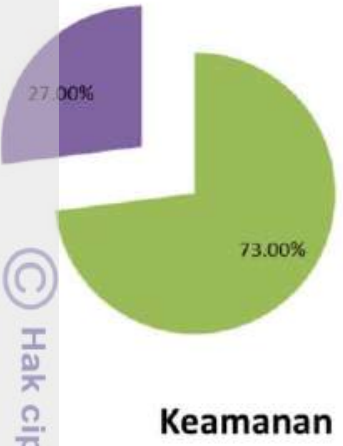

nangat bersih

m Bersih

cukup bersih

- Tidak bersih

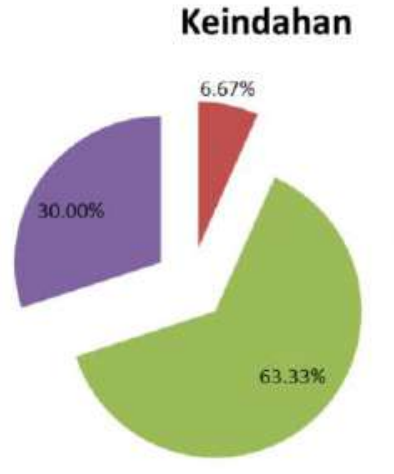

- Sangat indah

- Indah

- Cukup indah

- Tidak indah

Fasilitas

- Sangat aman

aman

- Cukup aman

- Tidak aman

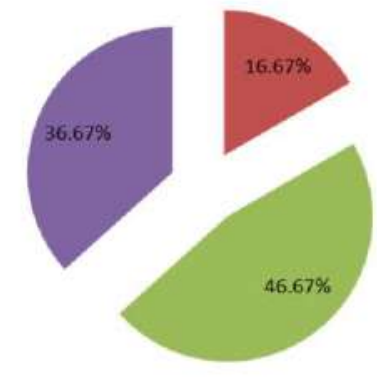

- Sangat baik

naik

- Cukup baik

Tidak baik

\section{Kenyamanan}
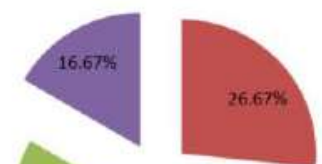

m Sangat nyaman

= Nyaman

w Cukup nyaman

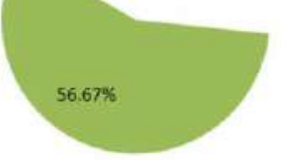

- Tidak nyaman

Gambar 38 Preferensi pejalan kaki mengenai kelima aspek di Jalan Padi

Preferensi pejalan kaki terhadap di Jalan Pakuan secara keseluruhan tergolong baik. Kondisi jalur pejalan kaki di Jalan Pakuan tidak begitu baik karena paving yang rusak dan bau yang tidak sedap dari drainase. Hal ini membuat pejalan kaki lebih memilih untuk berjalan di jalur kendaraan bermotor. Walaupun kondisi jalur pejalakan kaki kurang baik, preferensi pengguna terhadap aspek fasilitas pun tergolong cukup baik dan keberadaan tanaman peneduh yang mendominasi jalur hijau bagian tepi membuat pejalan kaki tetap merasa nyaman saat melintas. Grafik preferensi pengguna disajikan pada Gambar 39. 


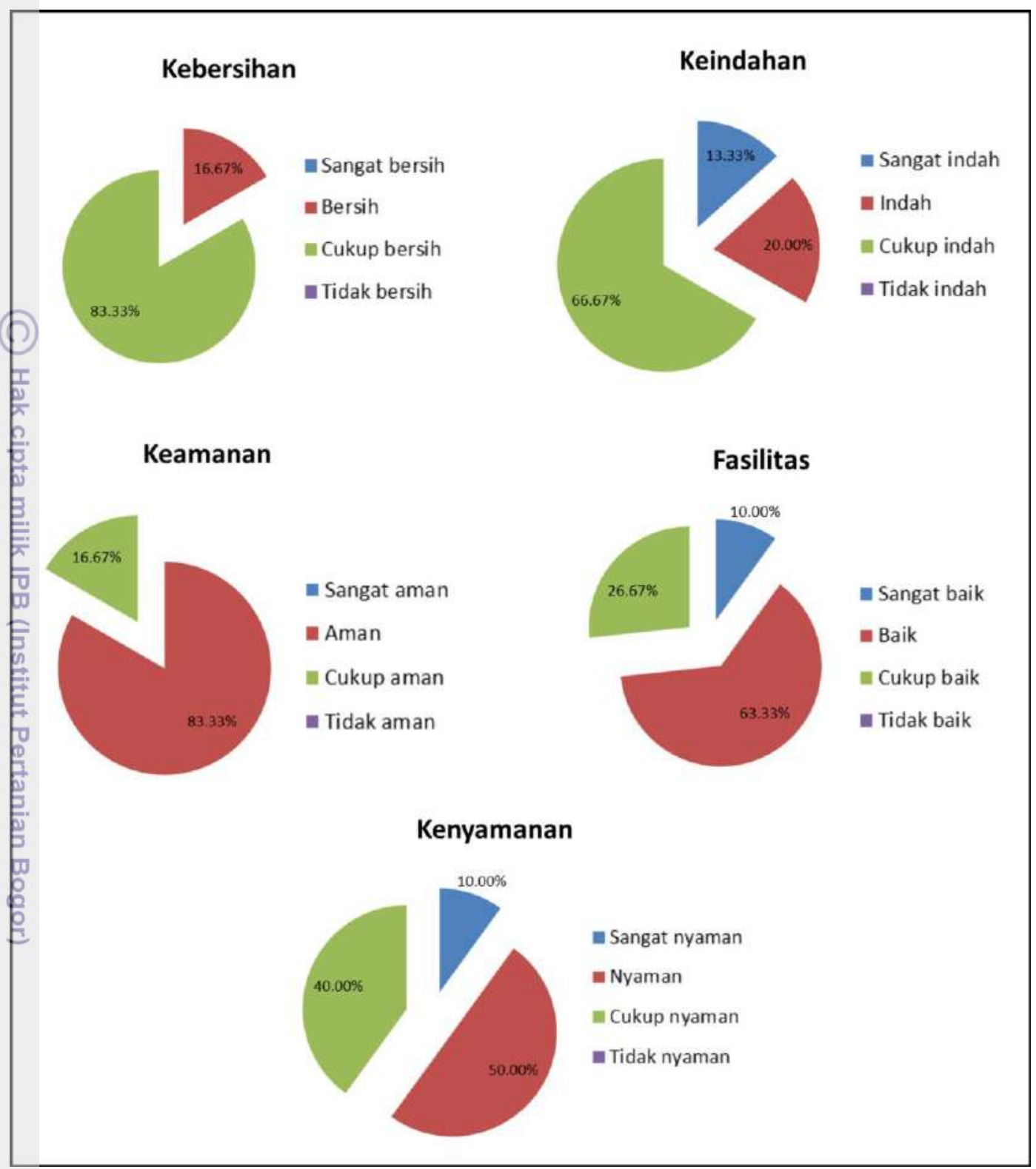

Gambar 39 Preferensi pejalan kaki mengenai kelima aspek di Jalan Pakuan

Secara keseluruhan, pengguna jalan (pedestrian) memberikan penilaian tertinggi pada aspek kebersihan jalur hijau di Jalan Raya Pajajaran Segmen I dan Jalan Bina Marga. Jalur hijau Jalan Pakuan mendapatkan penilaian tertinggi pada aspek keamanan dan kenyamanan. Pengguna jalan memberikan penilaian tertinggi pada aspek fasilitas di jalur hijau di Jalan Raya Pajajaran Segmen I dan Jalan (Pakuan. Penilaian tertinggi mengenai aspek keindahan diberikan untuk median F́l Jagorawi.

\section{Pengguna Kendaraan Bermotor}

Berikut adalah hasil preferensi pengguna kendaraan bermotor baik pengendara motor maupun mobil di empat titik lokasi. Preferensi pengguna jalan terhadap pengelolaan di Jalan Raya Pajajaran Segmen I tergolong baik. Penilaian 
tertinggi diberikan untuk aspek fasilitas. Sebagian besar responden menyatakan bahwa keberadaan tanaman tidak mengganggu jarak pandang. Sebagian besar responden menyatakan bahwa fasilitas di jalan raya seperti rambu dan marka jalan, serta papan informasi dapat terlihat dengan sangat jelas. Grafik preferensi pengguna disajikan pada Gambar 40.
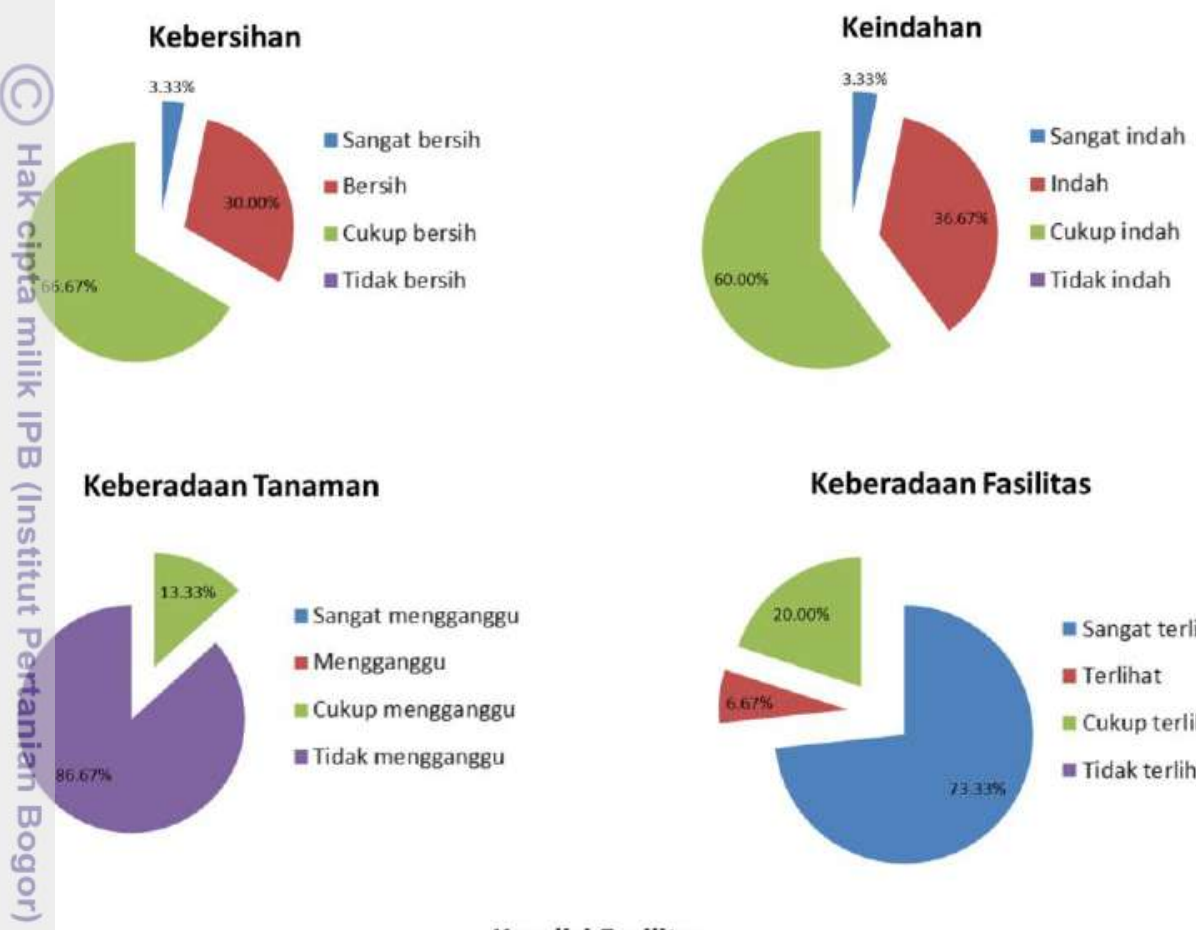

Keberadaan Fasilitas

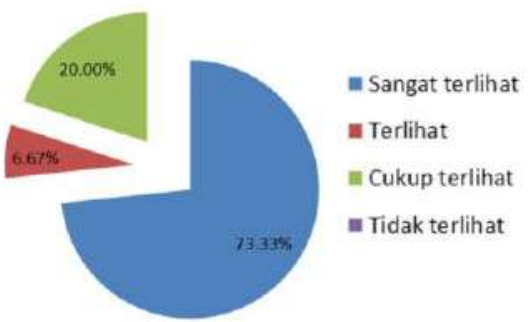

Kondisi Fasilitas

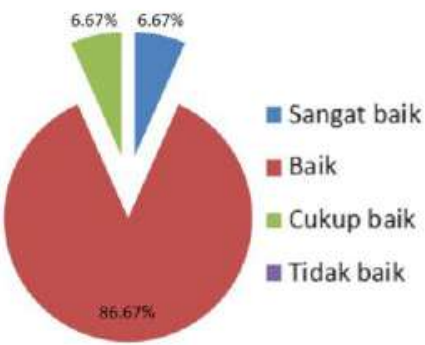

Gambar 40 Preferensi pengguna kendaraan bermotor di Jalan Raya Pajajaran Segmen I

Berikut adalah kritik dan saran yang diberikan oleh responden kepada pihakpengelola:

1.- melakukan pemangkasan terhadap semak dan perdu di median secara ¿ berkala agar tanaman terlihat rapi dan tidak mengganggu jarak pandang $\subseteq$ pengendara;

2.-melakukan pengawasan terhadap tajuk pohon perlu dilakukan agar tajuk tersebut tidak menutupi marka atau rambu jalan, serta melakukan pemangkasan ranting dengan segera. 
Preferensi responden terhadap pengelolaan di Jalan Raya Pajajaran Segmen II tergolong cukup baik. Penilaian tertinggi diberikan untuk aspek fasilitas. Sebagian besar responden menyatakan bahwa fasilitas di jalan Raya seperti rambu dan marka jalan, serta papan informasi dapat terlihat cukup jelas, tetapi terdapat beberapa marka terhalang oleh papan reklame atau signage. Grafik preferensi pengguna disajikan pada Gambar 41.

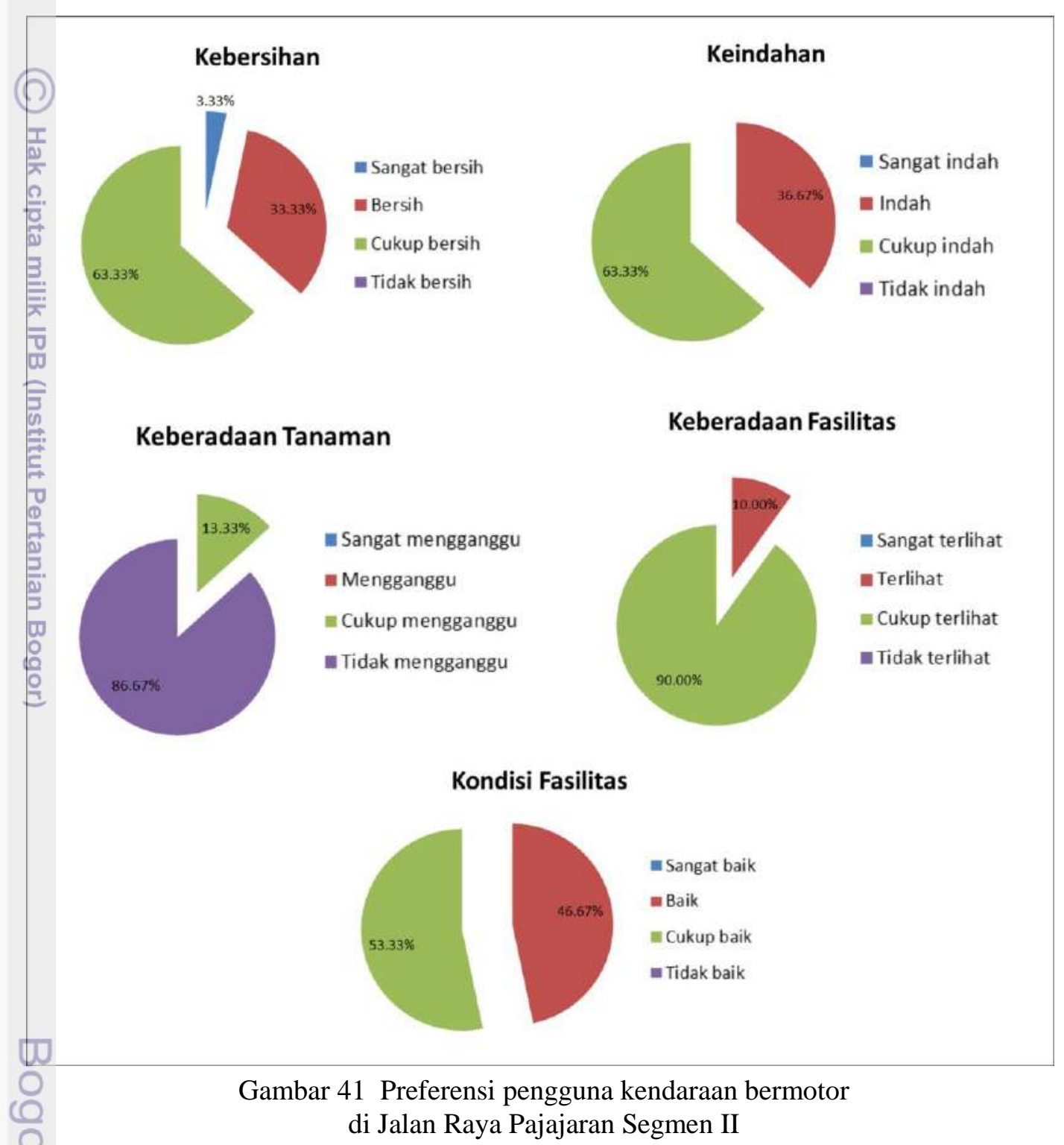

Sebagian besar responden lebih menyukai vegetasi berjenis pohon dari pada perdu dan semak. Oleh sebab itu, mereka lebih menyarankan untuk menambah jumlah rumput dan tanaman penutup tanah (ground cover) dari pada menambah jumlah semak dan perdu agar tidak mengganggu jarak pandang. 
Preferensi responden terhadap pengelolaan di Jalan Raya Pajajaran Segmen III tergolong cukup baik. Penilaian tertinggi diberikan untuk aspek fasilitas. Sebagian besar responden menyatakan bahwa fasilitas di jalan Raya seperti rambu dan marka jalan, serta papan informasi dapat terlihat dengan cukup jelas. Grafik preferensi pengguna disajikan pada Gambar 42.

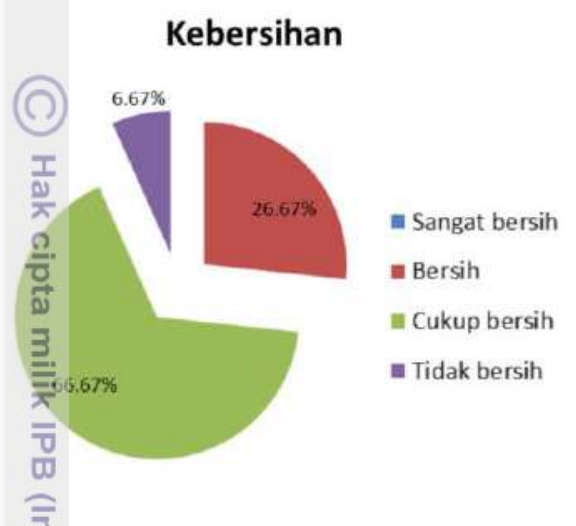

\section{Keberadaan Tanaman}

= Sangat mengganggu

= Mengganggu

w Cukup mengganggu

- Tidak mengganggu

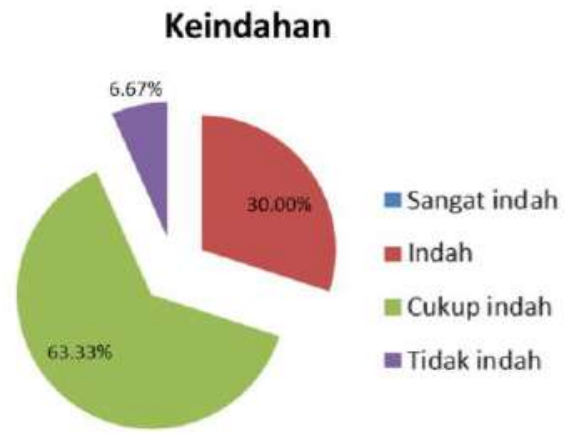

Keberadaan Fasilitas
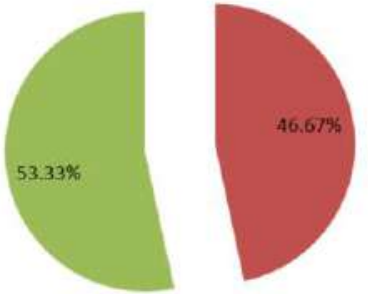

= Sangat terlihat

m Terlihat

m Cukup terlihat

m Tidak terlihat

\section{Kondisi Fasilitas}

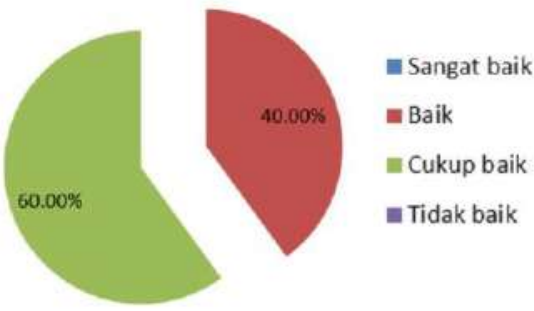

ए

ç

Gambar 42 Preferensi pengguna kendaraan bermotor

di Jalan Raya Pajajaran Segmen III

Preferensi responden terhadap pengelolaan di Tol Jagorawi cukup baik. Penilaian tertinggi diberikan untuk aspek fasilitas dan keindahan. Sebanyak $20 \%$ responden menyatakan fasilitas di median terlihat sangat jelas.

$\subseteq$ Terkait vegetasi, sebanyak $60 \%$ responden memberikan saran agar vegetasi yang ditanam di median Tol Jagorawi adalah vegetasi berjenis semak, perdu, atau ground cover yang tingginya kurang dari $1 \mathrm{~m}$ agar tidak mengganggu jarak pandang. Sebanyak $20 \%$ responden memberikan saran agar di median jalan 
ditambahkan pohon peneduh dan $20 \%$ responden lainnya tidak memberikan saran atau kritik terhadap median tol. Grafik preferensi pengguna disajikan pada Gambar 43.

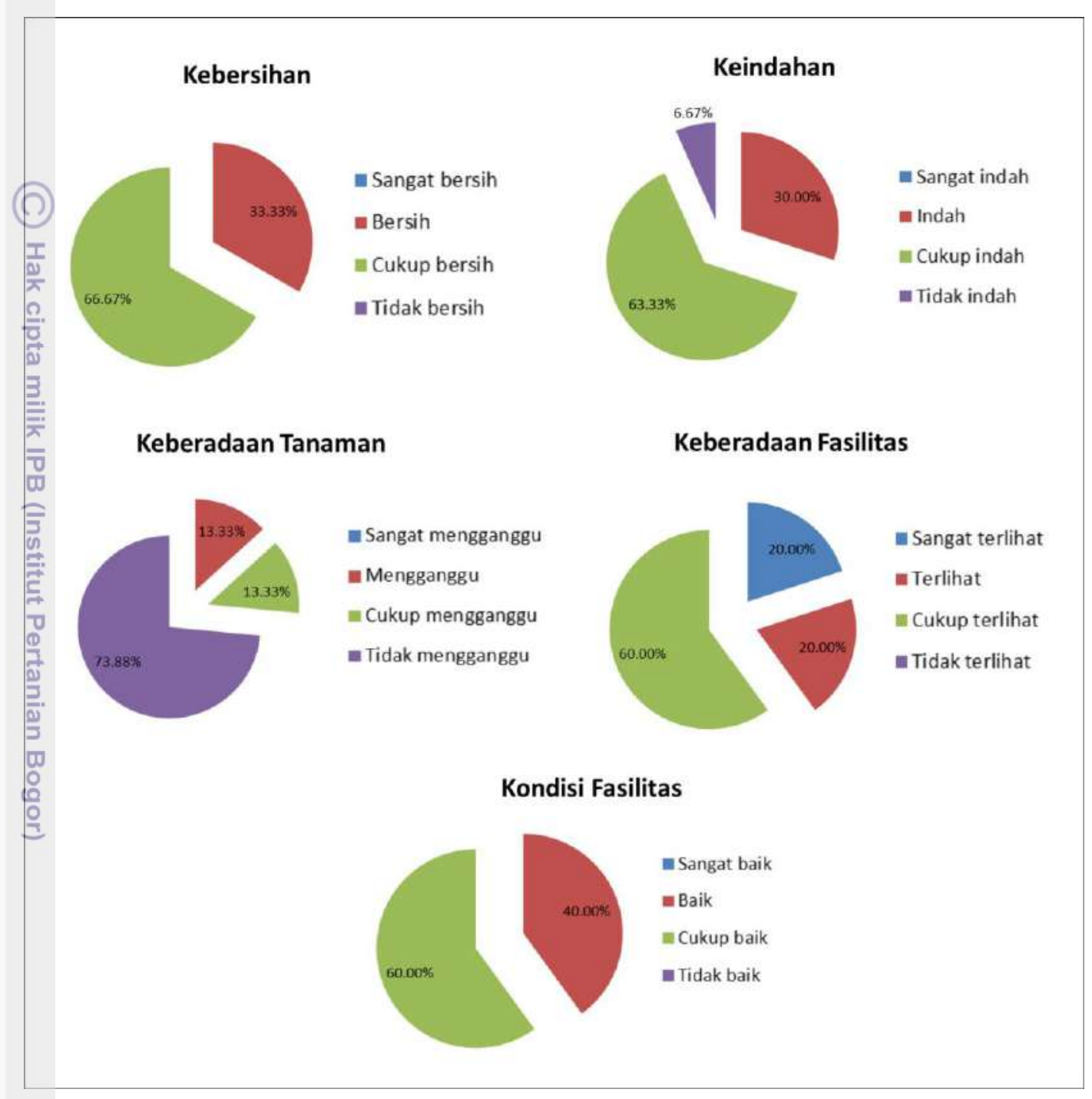

Gambar 43 Preferensi pengguna kendaraan bermotor di Tol Jagorawi

Secara keseluruhan, sebagian besar responden dapat melihat dengan jelas (fasilitas yang ada di tepi jalan maupun di median jalan. Keberadaan tanaman Qhususnya jenis perdu dan pohon umumnya tidak mengganggu jarak pandang pengguna kendaraan dalam melihat fasilitas jalan, saat berbelok atau berputar. Tol Jagorawi dan Jalan Raya Pajajaran Segmen II mendapatkan penilaian tertinggi pada aspek kebersihan.

\section{Analisis Kegiatan Pengelolaan}

Berikut adalah analisis kegiatan pengelolaan terkait struktur organisasi pengelola, tenaga kerja, jadwal kerja, alat dan bahan, serta anggaran biaya. 


\section{Struktur Organisasi Pengelola}

Terdapat perbedaan antara struktur organisasi pihak pengelola dengan literatur. Bidang pertamanan hanya memiliki 2 seksi, yaitu seksi pemeliharaan taman dan seksi pembangunan dan penataan taman, sedangkan Arifin dan Arifin merekomendasikan empat seksi dalam divisi pemeliharaan taman, yaitu seksi pemeliharaan tanaman, pemeliharaan bangunan taman, bengkel dan pergudangan, serta pemeliharaan perpipaan dan utilitas (Gambar 44).

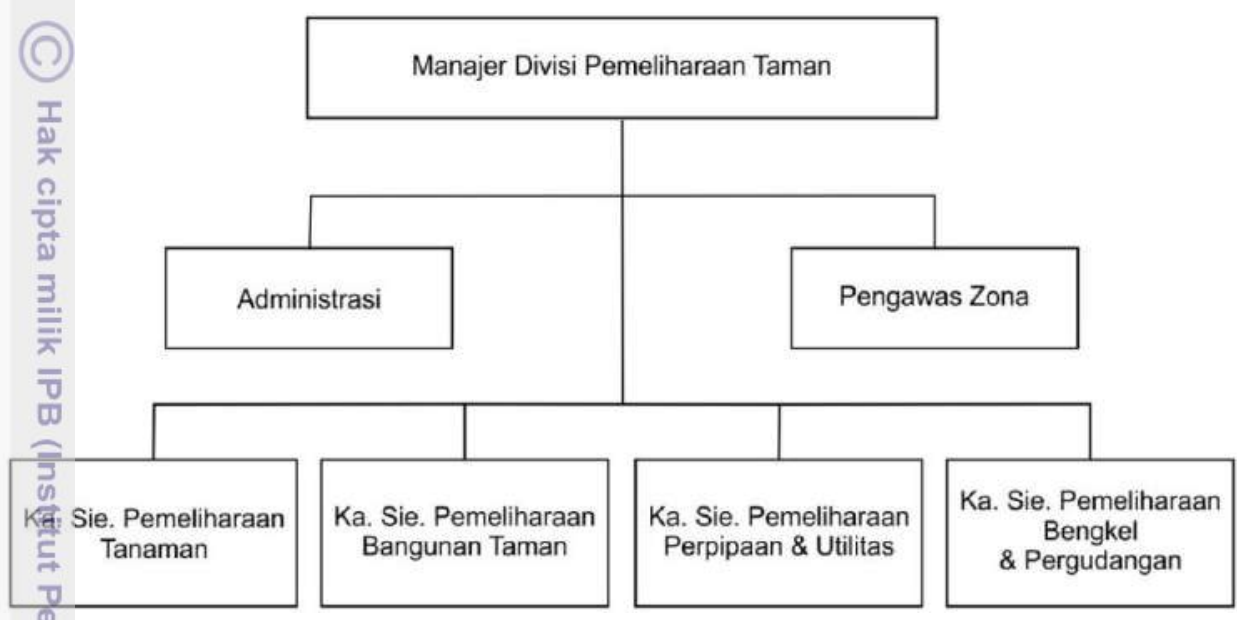

Gambar 44 Struktur organisasi yang dianjurkan Arifin dan Arifin (2005)

Pemelihara taman dianjurkan terdiri dari beberapa seksi agar dapat bekerja secarasspesifik. Hal ini bertujuan agar kegiatan pemeliharaan berlangsung efektif dan efisien.Berdasarkan rekomendasi struktur organisasi Arifin dan Arifin (2005), tugas seksi pemeliharaan tanaman meliputi berbagai pekerjaan pemeliharaan, seperti penyiraman, pembersihan, penyiangan gulma, penggemburan tanah, pemangkasan, dan berbagai kegiatan pemeliharaan lainnya. Seksi pemeliharaan bangunan bertugas untuk memelihara elemen tanaman keras. Tugas dari seksi teknik perpipaan adalah pengawasan dan pemeliharaan kelancaran kerja utilitas taman. Seksi bengkel dan pergudangan bertugas untuk melakukan inventarisasi alat, mengontrol kerja alat, dan memperbaikinyaa.

Kegiatan dari seksi pemeliharaan yang dianjurkan Arifin dan Arifin (2005) sama dengan kegiatan yang dilakukan oleh seksi pemeliharaan bidang pertamanan. Bidang pertamanan tidak melakukan pengawasan dan pemeliharaan perpipaan karena tugas tersebut menjadi tanggung jawab dari Bina Marga, Kota Bogor. Kegiatan pemeliharaan bangunan tidak dilakukan oleh bidang pertamanan. Pengetolaan dan pemeliharaan bangunan yang terdapat di jalur hijau menjadi tanggung jawab pihak yang membangun bangunan tersebut. Salah satu contohnya adalah pos DLLAJ di jalur hijau Jalan Raya Pajajaran Segmen I yang dibangun dan dikelola oleh DLLAJ. Terdapat perbedaan dari kegiatan yang dilakukan oleh seksi bengkel dan pergudangan. Seksi bengkel dan gudang dari bidang pertamanan hanya melakukan inventarisasi dan mengontrol kelancaran kerja alat. Kegiatan perbaikan suku cadang dilakukan oleh UPTD Peralatan dan Perbengkelan Kota Bogor. 


\section{Tenaga Kerja}

Kondisi pemeliharaan jalur hijau saat ini difokuskan pada tiga area, yaitu Tol Jagorawi, Jalan Raya Pajajaran, dan Taman sudut Bina Marga. Hal ini dikarenakan keterbatasan alat, bahan dan keterampilan para pekerja lapang. Kondisi tersebut menyebabkan kegiatan pemeliharaan jalur hijau jalan di Kelurahan Baranangsiang tidak berjalan optimal. Area kerja tim kored disajikan pada Gambar 45.

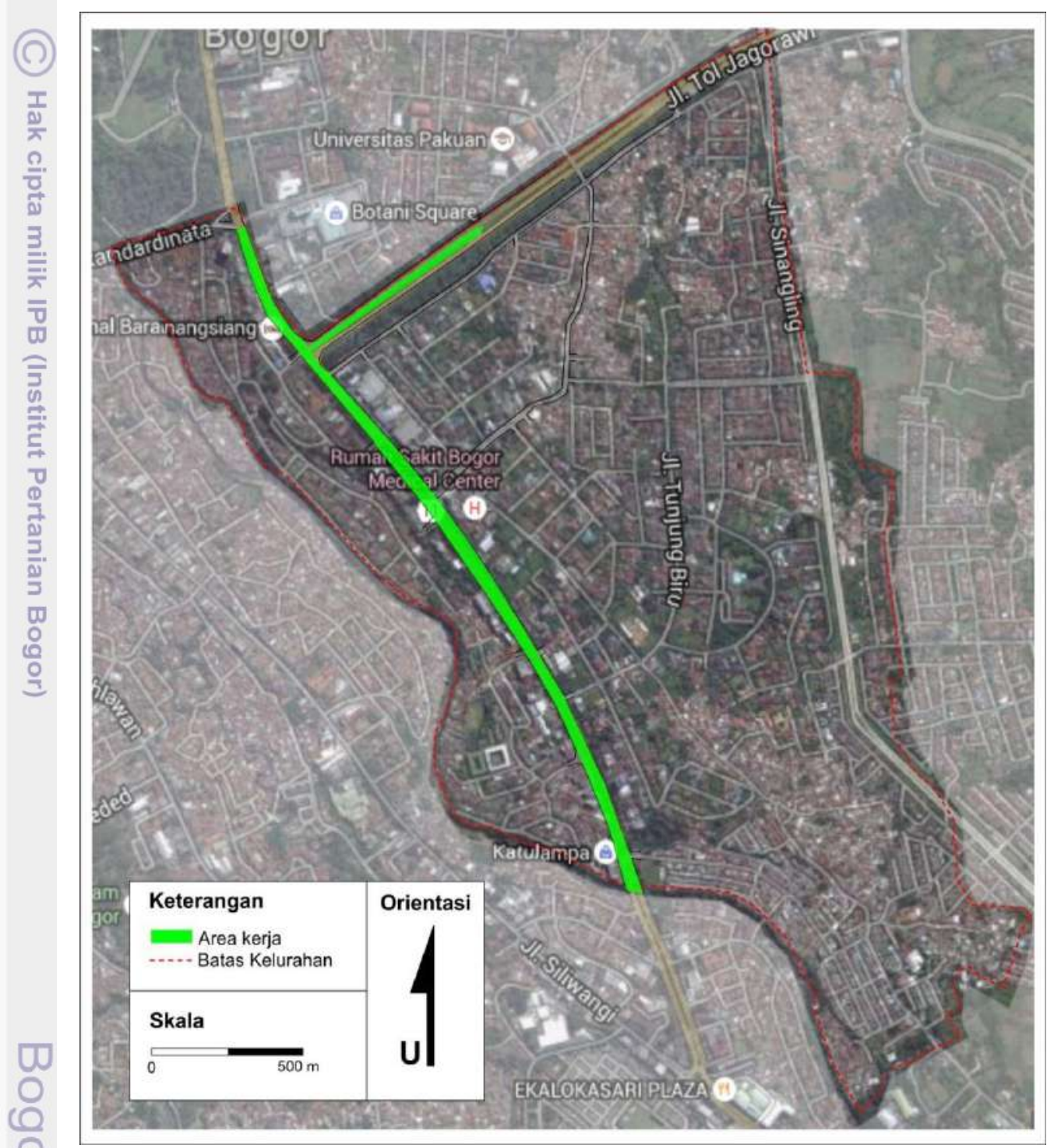

Gambar 45 Area kerja tim kored

Berdasarkan wawancara dengan bidang pertamanan dan mandor, serta pengamatan lapang, kegiatan pemupukan dan penyemprotan pestisida dilakukan secara insidental. Seluruh tenaga kerja lapang merupakan tenaga kerja lepas (padat karya), sedangkan mandor pegawai negri sipil. Kegiatan pemeliharaan Łarian dilakukan secara bersama-sama untuk memotivasi pekerja (Gambar 46). 

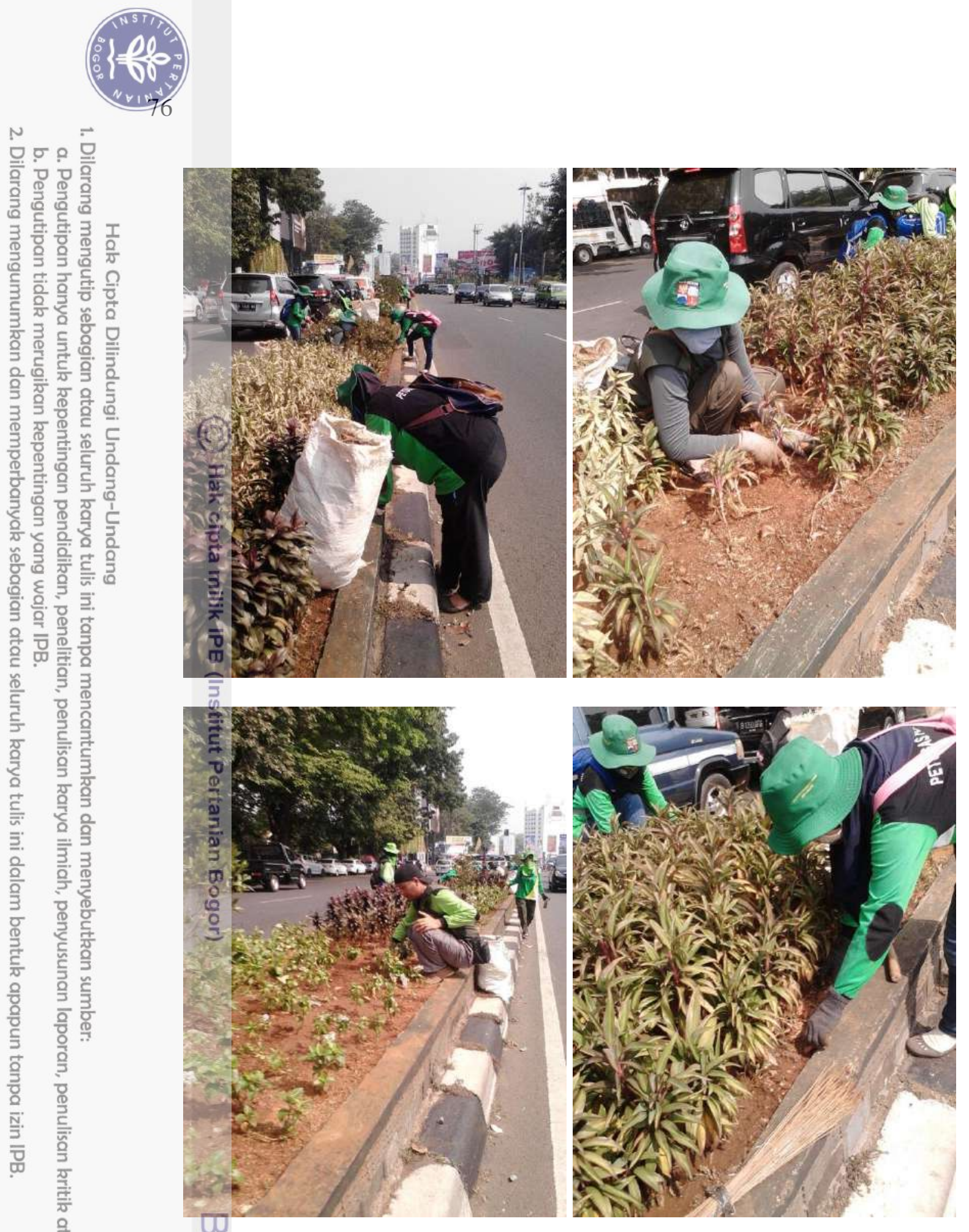

$$
\begin{gathered}
\text { Gambar } 46 \text { Kegiatan pemeliharaan dilakukan bersama-sama } \\
\text { Sumber: dokumentasi pribadi }
\end{gathered}
$$

Vegetasi jenis pohon yang dipelihara adalah pohon yang terdapat di jalur hijau, taman sudut, pulau jalan, dan median jalan. Vegetasi jenis tanaman penutup tanah (TPT) atau ground cover, semak, perdu dan tanaman merambat yang dipelihara oleh bidang pertamanan hanya vegetasi yang berada di median, taman sudut, dan pulau jalan. Semak, perdu, ground cover, dan tanaman merambat yang berada di tepi jalan dipelihara oleh masyarakat atau pemilik bangunan yang ada di dekatjalur hijau. 
Masyarakat di sekitar jalur hijau dan pihak swasta atau instansi (pihak eksternal) diperbolehkan melakukan pembangunan taman, pergantian tanaman, atau melakukan kegiatan lain di area jalur hijau setelah berkoordinasi dan mendapatkan izin dari Dinas Kebersihan dan Pertamanan. Salah satu contoh dari pembangunan taman dan pemeliharaan yang dilakukan pihak eksternal adalah pembangunan dan pemeliharaan Taman Botani Square yang berada di depan Botani Square (Gambar 47).

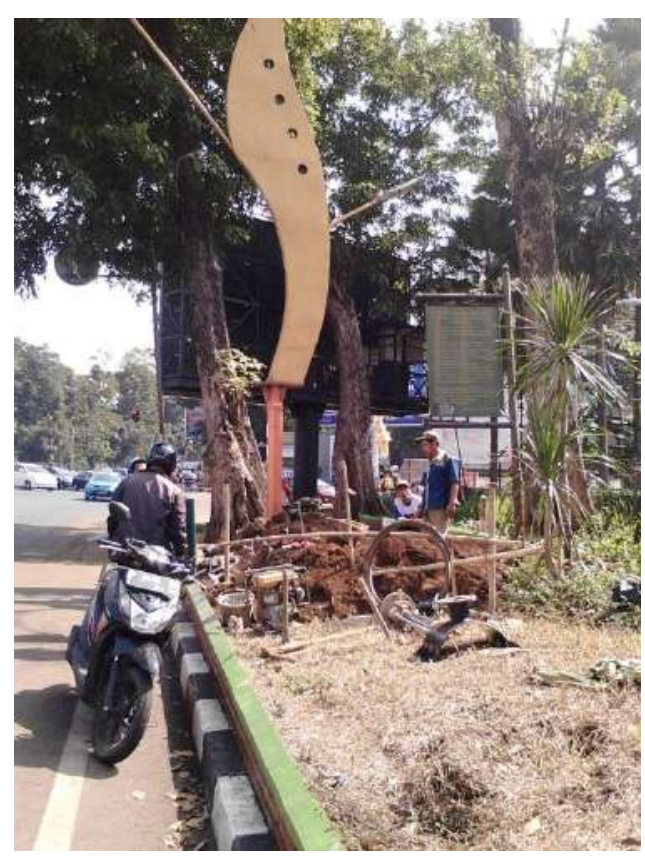

Gambar 47 Pembangunan Taman Botani Square Sumber: dokumentasi pribadi

\section{Jadwal Kerja}

Pekerja lapang melakukan kegiatan pemliharaan selama 5 jam/hari. Berdasarkan hasil pengamatan di lapang, jam kerja efektif dari kegiatan pemeliharaan jalur hijau jalan di Kelurahan Baranangsiang sekitar 4 jam dari 5 jam kerja per hari. Berdasarkan hasil wawancara dan pengamatan lapang, terdapat perbedaan dalam frekuensi kegiatan pemeliharaan yang dilakukan pekerja lapang dengan literatur (Tabel 42).

Tabel 42 Perbandingan frekuensi kegiatan literatur sebagai standar dan lapang

\begin{tabular}{llcc}
\hline \multirow{2}{*}{ No. Aktivitas } & \multicolumn{2}{c}{ Frekuensi } \\
\cline { 3 - 4 } & & Standar $^{1}$ & Lapang $^{2}$ \\
\hline 1 & Penyapuan rumput & Harian & Harian \\
2 & Pemangkasan rumput & Bulanan & Insidental \\
3 & Penyapuan perkerasan & Harian & Harian \\
4 & Pembuangan sampah & Harian & Harian \\
5 & Pemangkasan semak dan ground cover & Bulanan & Bulanan \\
6 & Penyiangan gulma dengan kored & Bulanan & Insidental \\
\hline B Berdasarkan pemeliharaan taman oleh Arifin dan Arifin (2005) & & \\
Berdasarkan hasil pengamatan lapang dan wawancara (Februari-April 2015) &
\end{tabular}




\section{Alat dan Bahan}

Alat dan bahan yang diperlukan dalam kegiatan pengelolaan menjadi tanggung jawab pihak Bidang Pertamanan dari Dinas Kebersihan dan Pertamanan. Kondisi peralatan pemeliharaan secara keseluruhan tergolong baik. Pergantian alat dilakukana secara berkala sesuai dengan masa susut alat. Masa susut dari masingmasing alat disajikan pada Tabel 43.

Tabel 43 Jumlah alat pemeliharaan selama satu tahun

\begin{tabular}{|c|c|c|c|c|}
\hline No. & Alat & Jumlah & Satuan & Masa Susut Alat (tahun) \\
\hline 1 & Cangkul & 2 & buah & 0,083 \\
\hline 2 & I Garpu tanah & 1 & buah & 0,500 \\
\hline 3 & Mesin pemangkas rumput & 1 & unit & 3,000 \\
\hline 4 & Parang & 4 & buah & 0,500 \\
\hline 5 & Gunting pangkas & 3 & buah & 0,500 \\
\hline 6 & Kored & 20 & buah & 0,500 \\
\hline 7 & 玄Pengki & 20 & buah & 0,083 \\
\hline 8 & W Sapu lidi & 20 & buah & 0,083 \\
\hline 9 & (Chainsaw & 1 & buah & 3,000 \\
\hline 10 & $\stackrel{\infty}{\cong}$ Seragam operator & 20 & unit & 0,500 \\
\hline 11 & Sarung tangan & 20 & unit & 0,083 \\
\hline 12 & Masker & 20 & buah & 0,083 \\
\hline
\end{tabular}

Sumber:- Dinas Kebersihan dan Pertamanan, wawancara dengan pekerja lapang, dan survei lapang

Alat dan bahan yang digunakan oleh pihak swasta atau masyarakat dalam membångun dan memelihara jalur hijau di Kelurahan Baranangsiang tidak disediâkan oleh Dinas Kebersihan dan Pertamanan dan menjadi tanggung jawab dari masyarakat atau swasta atau instansi terkait yang melakukan pembangunan taman.

\section{Anggaran Biaya}

Anggaran biaya pemeliharaan bersumber dari biaya APBD Kota Bogor. Berdasarkan hasil wawancara dengan Dinas Kebersihan dan Pertamanan, tidak terdapat kendala dalam proses pencairan dana. Pada tahun 2014, terdapat 2 jenis rencana anggaran biaya, yaitu rencana anggaran biaya untuk peralatan pemeliharaan dan rencana anggaran biaya untuk pembelian suku cadang. Saat ini, kegiatan penggantian suku cadang tidak lagi menjadi tanggung jawab Dinas Kebersihan dan Pertamanan. Oleh sebeb itu, rencana anggaran biaya saat ini hanyarmeliputi rencana anggaran untuk pengadaan alat dan bahan.

\section{Analisis SWOT}

\section{Faktor Strategis Internal}

5 Faktor strategis internal terdiri dari tiga faktor kekuatan (strengths) dan tiga faktor kelemahan (weaknesses).

\section{Kekuatan}

OFaktor kekuatan meliputi 
a. Koordinasi yang baik antar personal

Koordinasi yang baik antar personal dapat meminimalisir kesalahan kerja. Hal ini juga dapat menumbuhkan rasa saling percaya sehingga antarpekerja lapang atau personal dapat bekerja sama dengan baik. Faktor ini memiliki rating 3 (penting).

b. Pihak pengelola sudah memiliki struktur organisasi yang spesifik

Pihak pengelola harus memiliki struktur organisasi yang spesifik karena hal itu mempengaruhi efektivitas dan efisiensi kegiatan pemeliharaan. Struktur pengelolaan harus berfungsi dengan baik. Oleh sebab itu, faktor ini memiliki rating 3 (penting).

c. Pihak pengelola menciptakan iklim kompetitif agar personal dapat bekerja dengan optimal

Iklim kerja mempengaruhi kondisi kinerja. Menurut Rangkuti (1997), iklim kompetitif memberikan dorongan agar setiap personal dapat berprestasi. Kompetisi dan prestasi membuat personal dapat mencapai target kerja. Faktor ini memiliki rating 4 (sangat penting).

\section{Kelemahan}

Faktor kelemahan meliputi

1. Area kerja yang tidak sesuai dengan tanggung jawab

Area kerja yang tidak sesuai menyebabkan kebersihan dan penataan lanskap di beberapa area masih kurang. Kondisi ini mempengaruhi aspek kebersihan, kenyamanan dan keindahan jalur hijau jalan. Pengelolaan lanskap harus dilakukan dengan optimal. Faktor ini memiliki rating 2 (penting).

2. Terbatasnya alat dan bahan

Terdapat area kerja yang di lapang tidak sesuai dengan pembagian tanggung jawab. Keterbatasan alat dan bahan sangat mempengaruhi kegiatan pemeliharaan. Faktor ini memiliki rating 1 (sangat penting).

3. Tenaga kerja yang bukan tenaga ahli

Kemampuan pekerja lapang dalam kegiatan pemeliharaan mempengaruhi efektifitas kerja dan efisiensi waktu kerja yang dibutuhkan. Semakin terampil, maka semakin efisien dan efektif pula pekerjaan yang dilakukannya. Oleh sebab itu, faktor ini memiliki rating 1 (sangat penting).

\section{Faktor Strategis Eksternal}

Faktor strategis eksternal terdiri dari empat faktor peluang (opportunities) dan empat faktor ancaman (threats).

\section{Peluang}

Faktor peluang meliputi

1. Rencana pemerintah dalam mewujudkan kota hijau

Peraturan pemerintah Kota Bogor memberikan dampak positif bagi seluruh pihak, baik pengelola, instansi terkait maupun masyarakat Kota Bogor. Faktor ini memiliki rating 4 (sangat penting).

2. Adanya kesadaran dan partisipasi masyarakat 
Pengelolaan akan semakin optimal dengan adanya dukungan atau partisipasi dari pihak eksternal. Faktor ini memiliki rating 3 (penting).

3. Partisipasi pihak swasta dalam bantuan teknologi

Faktor ini memiliki rating 3 (penting).

4. Kerja sama dengan paguyuban nursery dalam menyuplai kebutuhan tanaman

Kerja sama ini dapat menguntungkan kedua belah pihak dengan tujuan memberdayakan paguyuban nursery yang berada di Jalan Raya Pajajaran, Kota Bogor. Faktor ini memiliki rating 3 (penting).

\section{Ancaman}

Faktor kekuatan meliputi

1. Keberadaan pedagang kaki lima

Keberadaan pedagang kaki lima membuat kenyamanan, dan keindahan jalur hijau jalan Kelurahan Baranangsiang berkurang. Faktor ini memiliki ${ }_{\overline{2}}$ rating 1 (sangat penting).

2. WVandalisme

-Vandalisme adalah penghancuran yang dilakukan baik dengan sengaja maupun tidak terhadap sesuatu yang indah, dihormati dan dipelihara. ¿Vandalisme juga didefinisikan sebagai kegiatan pengrusakan barang milik Tumum. Ancaman ini sangat mengganggu proses pengelolaan jalur hijau 7jalan di Kelurahan Baranangsiang. Oleh sebab itu, faktor ini memiliki Jating 1 (sangat penting).

3. Perubahan cuaca

${ }_{0}$ Perubahan cuaca mempengaruhi kondisi lapang dan kinerja pekerja olapang. Faktor ini memiliki rating 3 (cukup penting).

4. Kecelakaan kerja

Kecelakaan kerja dapat membuat jumlah personal berkurang. Hal ini mempengaruhi efektivitas dan efisiensi kerja. Faktor ini memiliki rating 3 (cukup penting).

Setelah mendapatkan faktor-faktor yang mempengaruhi, dilakukan analisis tingkat kepentingan faktor internal dan eksternal (Tabel 44 dan 45).

Tabel 44 Tingkat kepentingan faktor internal

\begin{tabular}{|c|c|c|c|}
\hline Simbol & Faktor Internal & $\begin{array}{l}\text { Tingkat } \\
\text { Kepentingan }\end{array}$ & Rating \\
\hline \multicolumn{4}{|c|}{ Faktorkekuatan (strengths) } \\
\hline S10 & Koordinasi yang baik antar personal & Penting & 3 \\
\hline $\mathrm{S} 2 \underset{\mathrm{C}}{\mathrm{D}}$ & $\begin{array}{l}\text { Pihak pengelola sudah memiliki struktur } \\
\text { organisasi yang spesifik }\end{array}$ & Penting & 3 \\
\hline $\mathrm{S} 3 \frac{\mathrm{O}}{\mathrm{Z}}$ & $\begin{array}{l}\text { Pihak pengelola menciptakan iklim kompetitif } \\
\text { agar personal dapat bekerja dengan optimal }\end{array}$ & Sangat penting & 4 \\
\hline \multicolumn{4}{|c|}{ Faktor kelemahan (weaknesses) } \\
\hline $\mathrm{W} 1=$ & Area kerja yang tidak sesuai & Penting & 2 \\
\hline W2E & Terbatasnya alat dan bahan & Sangat penting & 1 \\
\hline W3 3 & Tenaga kerja bukan tenaga ahli & Sangat penting & 1 \\
\hline (1) & & Total & 14 \\
\hline
\end{tabular}


Tabel 45 Tingkat kepentingan faktor eksternal

\begin{tabular}{|c|c|c|c|}
\hline Simbol & Faktor Eksternal & $\begin{array}{c}\text { Tingkat } \\
\text { Kepentingan }\end{array}$ & Rating \\
\hline \multicolumn{4}{|c|}{ Faktor peluang (opportunities) } \\
\hline O1 & $\begin{array}{l}\text { Rencana pemerintah dalam mewujudkan kota } \\
\text { hijau }\end{array}$ & Sangat penting & 4 \\
\hline $\mathrm{O} 2$ & Adanya kesadaran dan partisipasi masyarakat & Penting & 3 \\
\hline $\mathrm{O} 3$ & $\begin{array}{l}\text { Partisipasi pihak swasta dalam bantuan } \\
\text { teknologi }\end{array}$ & Penting & 3 \\
\hline (()) $\mathrm{O} 4$ & $\begin{array}{l}\text { Kerja sama dengan paguyuban nursery dalam } \\
\text { menyuplai kebutuhan tanaman }\end{array}$ & Penting & 3 \\
\hline \multicolumn{4}{|c|}{ Eaktor ancaman (threats) } \\
\hline $\bar{n} \mathrm{~T} 1$ & Keberadaan pedagang kaki lima & Sangat penting & 1 \\
\hline न $\mathrm{T} 2$ & Vandalisme & Sangat penting & 1 \\
\hline T3 & Perubahan cuaca & Cukup penting & 3 \\
\hline $\mathrm{T}$ T4 & Kecelakaan kerja & Cukup penting & 3 \\
\hline$\overline{\bar{\lambda}}$ & & Total & 21 \\
\hline
\end{tabular}

Selanjutnya, dilakukan penilaian bobot strategis internal (Tabel 46) dan èksternal (Tabel 47) menggunakan metode paired compatison dari Kinnear dan Taylor (1991).

Tabel 46 Penilaian bobot strategis internal

\begin{tabular}{|c|c|c|c|c|c|c|c|c|c|}
\hline \multicolumn{2}{|c|}{$\begin{array}{l}\text { Faktor } \\
\text { Internal }\end{array}$} & S1 & $\mathrm{S} 2$ & S3 & W1 & W2 & W3 & Total & Bobot \\
\hline ए & S1 & & 2 & 1 & 2 & 1 & 1 & 7 & 0,11 \\
\hline$\therefore$ & S2 & 2 & & 1 & 2 & 1 & 1 & 7 & 0,11 \\
\hline 윽 & S3 & 3 & 3 & & 3 & 2 & 2 & 13 & 0,21 \\
\hline & W1 & 2 & 2 & 1 & & 1 & 1 & 7 & 0,11 \\
\hline & W2 & 3 & 3 & 2 & 3 & & 2 & 13 & 0,21 \\
\hline & W3 & 3 & 3 & 2 & 3 & 2 & & 13 & 0,21 \\
\hline & & & & & & & Total & 60 & 1 \\
\hline
\end{tabular}

Tabel 47 Penilaian bobot strategis eksternal

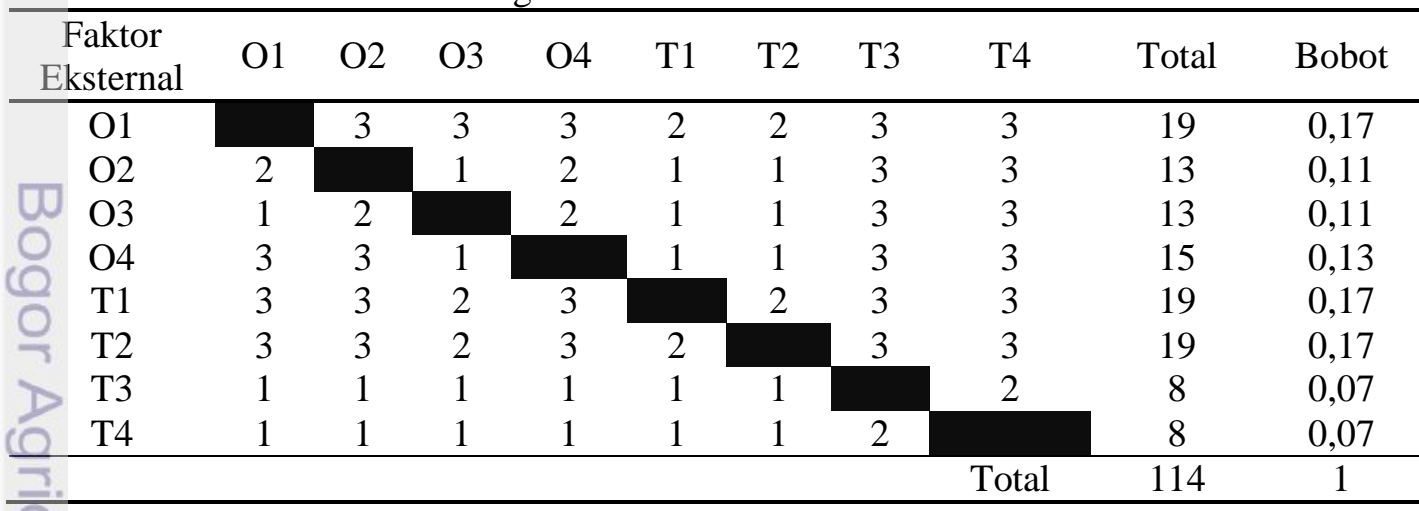

Tahapan selanjutnya adalah membuat Matriks Internal Factor Evaluation (IFE) dan Matriks External Factor Evaluation (EFE) untuk menentukan kekuatan Kondisi internal dan eksternal dari tapak. Matriks IFE disajikan pada Tabel 48 dan Matriks EFE disajikan pada Tabel 49. 
Tabel 48 Matriks Internal Factor Evaluation (IFE)

\begin{tabular}{|c|c|c|c|c|c|}
\hline Simbol & Faktor Internal & $\begin{array}{c}\text { Tingkat } \\
\text { Kepentingan }\end{array}$ & Rating & Bobot & Skor \\
\hline \multicolumn{6}{|c|}{ Faktor kekuatan (strengths) } \\
\hline S1 & $\begin{array}{l}\text { Koordinasi yang baik antar } \\
\text { personal }\end{array}$ & Penting & 3 & 0,11 & 0,35 \\
\hline S2 & $\begin{array}{l}\text { Pihak pengelola sudah memiliki } \\
\text { struktur organisasi yang spesifik }\end{array}$ & Penting & 3 & 0,11 & 0,35 \\
\hline $\begin{array}{c}\text { S3 } \\
\text { Faktor Kel }\end{array}$ & $\begin{array}{l}\text { Pihak pengelola menciptakan } \\
\text { iklim kompetitif agar personal } \\
\text { dapat bekerja dengan optimal } \\
\text { lamahan (weaknesses) }\end{array}$ & Sangat penting & 4 & 0,21 & 0,86 \\
\hline $\mathrm{W} 1 \frac{\mathrm{I}}{\mathrm{D}}$ & Area kerja yang tidak sesuai & Penting & 2 & 0,11 & 0,23 \\
\hline $\mathrm{W} 2 \bar{\lambda}$ & Terbatasnya alat dan bahan & Sangat penting & 1 & 0,21 & 0,22 \\
\hline W3 $\frac{2}{2} \cdot$ & Tenaga kerja bukan tenaga ahli & Sangat penting & 1 & 0,21 & 0,22 \\
\hline का & & & & Total & 2,23 \\
\hline Tabel $\frac{3}{49}$ & \multicolumn{5}{|c|}{ Matriks External Factor Evaluation (EFE) } \\
\hline Simbo高 & Faktor Eksternal & $\begin{array}{c}\text { Tingkat } \\
\text { Kepentingan }\end{array}$ & Rating & Bobot & Skor \\
\hline \multicolumn{6}{|c|}{ Faktor peluang (opportunities) } \\
\hline $\mathrm{O} 1 \stackrel{n}{\rightleftarrows}$ & $\begin{array}{l}\text { Rencana pemerintah dalam } \\
\text { mewujudkan kota hijau }\end{array}$ & Sangat penting & 4 & 0,17 & 0,7 \\
\hline $\mathrm{O} 2 \underset{\frac{0}{7}}{\frac{7}{7}}$ & $\begin{array}{l}\text { Adanya kesadaran dan } \\
\text { partisipasi masyarakat }\end{array}$ & Penting & 3 & 0,11 & 0,33 \\
\hline $\mathrm{O} 3 \stackrel{\mathrm{d}}{\mathrm{m}}$ & $\begin{array}{l}\text { Partisipasi pihak swasta dalam } \\
\text { bantuan teknologi }\end{array}$ & Penting & 3 & 0,11 & 0,33 \\
\hline 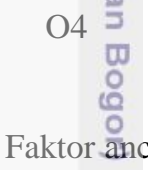 & $\begin{array}{l}\text { Kerja sama dengan paguyuban } \\
\text { nursery dalam menyuplai } \\
\text { kebutuhan tanaman } \\
\text { caman (threats) }\end{array}$ & Penting & 3 & 0,13 & 0,39 \\
\hline $\mathrm{T} 1$ & $\begin{array}{l}\text { Keberadaan pedagang kaki } \\
\text { lima }\end{array}$ & Sangat penting & 1 & 0,17 & 0,17 \\
\hline $\mathrm{T} 2$ & Vandalisme & Sangat penting & 1 & 0,17 & 0,17 \\
\hline T3 & Perubahan cuaca & Cukup penting & 3 & 0,07 & 0,21 \\
\hline \multirow[t]{2}{*}{$\mathrm{T} 4$} & Kecelakaan kerja & Cukup penting & 3 & 0,07 & 0,21 \\
\hline & & & & Total & 2,51 \\
\hline
\end{tabular}

Berdasarkan tabel, didapatkan total nilai IFE sebesar 2,23 dan total nilai EFE sebesar 2,51. Tahap selanjutnya adalah membuat Matriks Internal-Eksternal untuk menentukan kekuatan kondisi internal dan eksternal dari tapak (Tabel 50).

Tabel 50 Matriks Internal-Eksternal

\begin{tabular}{|c|c|c|c|}
\hline Total Skor IFE & $\begin{array}{c}\text { Kuat } \\
(3,00-4,00)\end{array}$ & $\begin{array}{l}\text { Rata-rata } \\
(2,00-2,99)\end{array}$ & $\begin{array}{c}\text { Lemah } \\
(1,00-1,99)\end{array}$ \\
\hline $\begin{array}{l}\text { Tinggi } \\
(3,00-4,00)\end{array}$ & I & II & III \\
\hline $\begin{array}{l}\text { Menengah } \\
(2,00-2,99)\end{array}$ & IV & $\mathrm{V}$ & VI \\
\hline $\begin{array}{l}\text { Eendah } \\
( \pm, 00-1,99)\end{array}$ & VII & VIII & IX \\
\hline
\end{tabular}


Menurut David (2008), jika nilai total skor IFE dan EFE berada di bawah 2,50, diindikasikan bahwa kondisi internal dan eksternal tergolong lemah. Jika nilai total skor IFE dan EFE berada di atas 2,50, diindikasikan bahwa kondisi internal dan eksternal tergolong kuat. Skor IFE yang diperoleh dari hasil perhitungan adalah adalah 2,23. Hal ini menunjukkan kondisi internal yang lemah. Berdasarkan perhitungan, skor EFE yang dimiliki adalah 2,51. Hal ini menujukkan kondisi eksternal dari jalur hijau jalan Baranangsiang tergolong kuat.

Berdasarkan Tabel 50, posisi skor IFE dan EFE jalur hijau jalan di Baranangsiang berada pada Sel V. Tipe strategi yang paling tepat untuk digunakan adalah dengan menjaga dan mempertahankan (hold and maintain). Hal ini 丽enunjukkan bahwa pihak pengelola harus menjaga keseimbangan sistem pengelolaan yang sudah dicapai sekaligus tetap berupaya untuk meningkatkan sistem pengelolaannya. Setelah membuat Matriks Intenal Eksternal, dibuat Matriks SWOT dengan menyesuaikan kekuatan dan kelemahan yang dimiliki dengan peluang dan ancaman yang diprediksi akan terjadi (Tabel 51).

\section{市abel 51 Matriks SWOT}

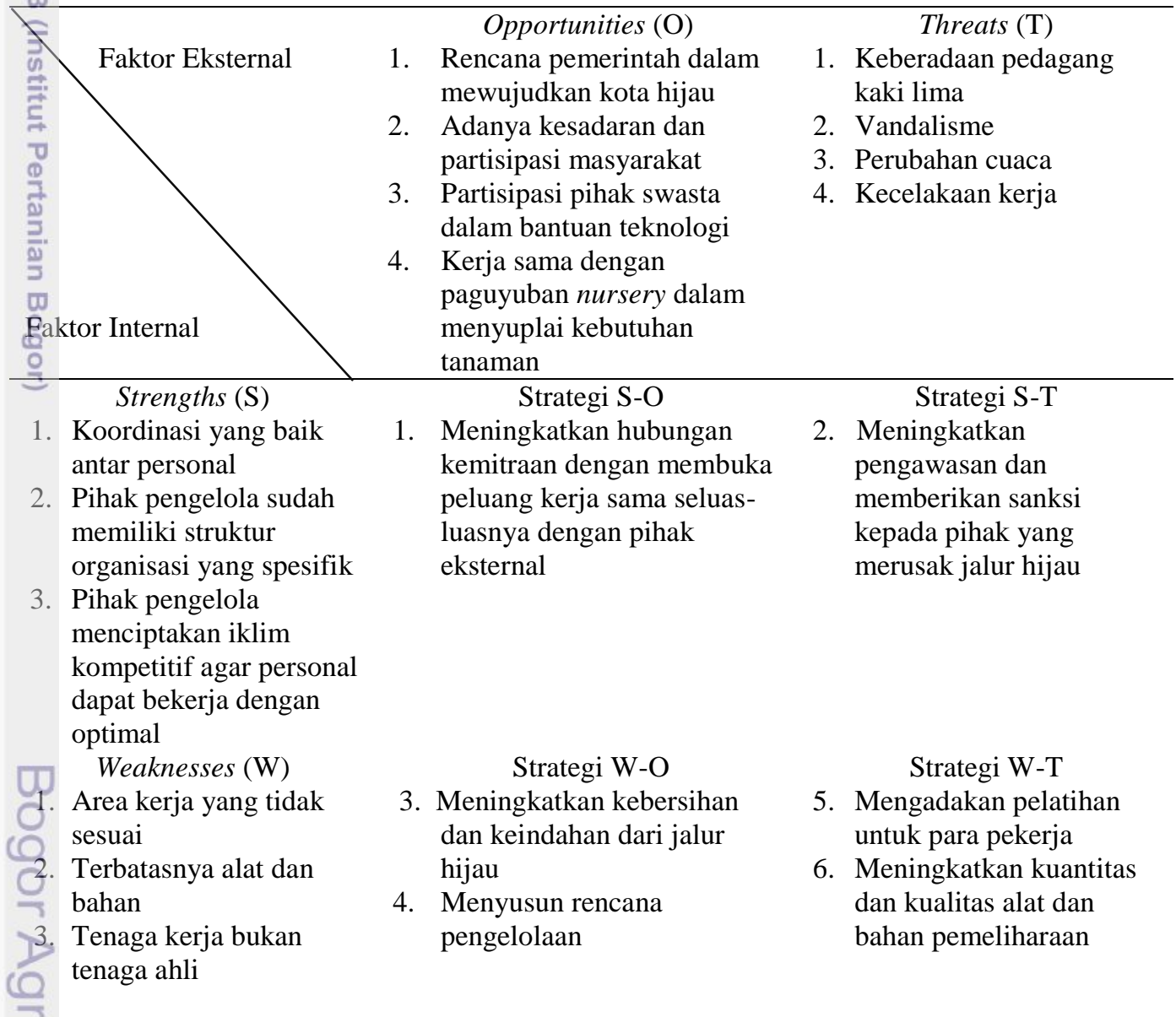

Berdasarkan Tabel 51, didapatkan enam alternatif strategi yang terdiri atas Istrategi S-O (stregths-opportunities), 1 strategi S-T (strength-threats), 2 strategi W-O (weaknesses-opportunities), dan 2 strategi W-T (weaknesses-threats). 


\section{Alternatif Strategi}

Perhitungan skor dari setiap alternatif strategi dilakukan dengan cara menjumlahkan skor dari unsur-unsur SWOT yang termasuk dalam masing-masing alternatif strategi. Kemudian, dilakukan penentuan peringkat dari masing-masing alternatif strategi (Tabel 52).

Tabel 52 Peringkat alternatif strategi

\begin{tabular}{|c|c|c|c|c|}
\hline No. & Alternatif Strategi & $\begin{array}{l}\text { Unsur } \\
\text { SWOT }\end{array}$ & Skor & Peringkat \\
\hline 1 & $\begin{array}{l}\text { Meningkatkan hubungan kemitraan } \\
\text { dengan membuka peluang kerja sama } \\
\text { Seluas-luasnya dengan pihak eksternal }\end{array}$ & $\begin{array}{l}\mathrm{S} 1, \mathrm{~S} 2 \\
\mathrm{O} 1, \mathrm{O} 2 \\
\mathrm{O} 3, \mathrm{O} 4\end{array}$ & 2,45 & 1 \\
\hline 2 & $\begin{array}{l}\text { Meningkatkan kebersihan dan keindahan } \\
\text { dari jalur hijau }\end{array}$ & $\begin{array}{l}\mathrm{O} 1, \mathrm{O} 3 \\
\mathrm{O} 4, \mathrm{~W} 1 \\
\mathrm{~W} 2\end{array}$ & 1,87 & 2 \\
\hline 3 & $\overline{\bar{M}}$ enyusun rencana pengelolaan & $\begin{array}{l}\mathrm{O} 1, \mathrm{~W} 3 \\
\mathrm{~W} 2, \mathrm{~W} 1\end{array}$ & 1,37 & 4 \\
\hline 4 & $\begin{array}{l}\text { Meningkatkan pengawasan dan } \\
\text { memberikan sanksi kepada pihak yang } \\
\text { merusak jalur hijau }\end{array}$ & $\begin{array}{l}\mathrm{S} 1, \mathrm{~S} 2 \\
\mathrm{~T} 1, \mathrm{~T} 2\end{array}$ & 1,04 & 5 \\
\hline 5 & $\begin{array}{l}\text { Mengadakan pelatihan untuk para } \\
\text { pekerja }\end{array}$ & $\begin{array}{l}\text { W1, W3, } \\
\text { T3, T4 }\end{array}$ & 0,87 & 6 \\
\hline 6 & $\begin{array}{l}\text { Meningkatkan kuantitas dan kualitas alat } \\
\text { dan bahan pemeliharaan }\end{array}$ & $\begin{array}{l}\text { W1, W2, } \\
\text { T3, T4 }\end{array}$ & 0,87 & 7 \\
\hline
\end{tabular}

Meniñ seluas-luasnya dengan pihak eksternal

Strategi ini merupakan strategi S-O, yang memanfaatkan seluruh kekuatan untuk memanfaatkan peluang sebesar-besarnya. Pihak pengelola telah bekerja sama dengan beberapa pihak eksternal dalam kegiatan pemeliharaan RTH terutama di jalur hijau jalan Kelurahan Baranangsiang. Pihak pengelola berupaya mempertahankan hubungan kemitraan dan juga membuka peluang kerja sama seluas-luasnya dalam upaya optimalisasi pengelolaan ruang terbuka hijau.

\section{Meningkatkan kebersihan dan keindahan dari jalur hijau}

Strategi ini tergolong strategi W-O, yang bertujuan meminimalisasi kelemahan untuk memanfaatkan peluang. Keterbatasan alat dan bahan menjadi kendata dalam kegiatan pemeliharaan. Oleh sebab itu, Dinas Kebersihan dan Pertamanan perlu memanfaatkan potensi yang ada melalui kerja sama yang dibangun dengan instansi pemerintah maupun swasta.

\section{Menyusun rencana pengelolaan}

Strategi ini tergolong strategi W-O, yang bertujuan meminimalisasi kelemahan untuk memanfaatkan peluang. Rencana pengelolaan yang disusun terdiri atas lima aspek, yaitu struktur organisasi, jadwal kegiatan, tenaga kerja, alat dan bahan serta biaya pengelolaan. 


\section{Meningkatkan pengawasan dan memberikan sanksi kepada pihak yang merusak jalur hijau jalan}

Strategi ini merupakan strategi W-T, yaitu meminimalisasi kelemahan dan menghindari ancaman. Pengawasan dari pihak pengelola harus lebih ditingkatkan untuk meminimalisir kerusakan yang terjadi akibat vandalisme dan keberadaan pedagang kaki lima (PKL) ilegal yang berjualan serta menetap di jalur pejalan kaki. Pemberian sanksi juga diperlukan untuk memberikan efek jera.

\section{Mengadakan pelatihan untuk para pekerja}

Strategi ini merupakan strategi W-T, yaitu meminimalisasi kelemahan dan 丽enghindari ancaman. Selain faktor alat dan bahan, kualitas sumber daya manusia m̄enjadi faktor penting dalam kegiatan pengelolaan. Diperlukan pelatihan untuk meningkatkan kemampuan dan menambah wawasan para pekerja. Selain pekerja dapat mengetahui dan menggunakan teknologi terbarukan, pekerja juga diharapkan dapat membuat inovasi dalam kegiatan pemeliharaan sehingga pekerjaan menjadi efektif dan efisien. Menurut Arifin dan Arifin (2005), efektivitas kerja para pekerja menentukan efisiensi biaya pemeliharaan taman.

三

\section{Meningkatkan kuantitas dan kualitas alat dan bahan pemeliharaan}

달 Strategi ini tergolong strategi W-O, yang bertujuan meminimalisasi Kelemahan dan untuk memanfaatkan peluang. Menurut Arifin dan Arifin (2005), keberadaan sarana dan prasarana yang memadai dalam kegiatan pengelolaan menjadi kunci keberhasilan. Kuantitas dan kualitas dari alat dan bahan yang đ̈igunakan mempengaruhi efektivitas kerja dan efisiensi waktu. Penggunaan Teknologi terbarukan akan menjadi optimal jika digunakan oleh tenaga kerja yang terampil.

\section{Rencana Pengelolaan}

Rencana pengelolaan merupakan salah satu hasil yang didapat dari alternatif strategi. Rencana pengelolaan yang direkomendasikan kepada Dinas Kebersihan dan Pertamanan, Kota Bogor, meliputi struktur organisasi, tenaga kerja, jadwal kegiatan, alat dan bahan, serta rencana anggaran biaya.

\section{Struktur Organisasi}

Struktur organisasi yang direkomendasikan mengacu pada Arifin dan Arifin (2005). Terdapat perbedaan antara struktur organisasi pihak pengelola đengan literatur. Administrasi dari setiap bagian diserahkan ke masing-masing Seksi, yaitu seksi pemeliharaan tanaman dam seksi pemeliharaan bengkel dan pergudangan. Tugas dari seksi bengkel dan pergudangan adalah menginventarisasi peralatan, dan mengontrol kelancaran kerja alat. Struktur organisasi yang direkomendasikan disajikan pada Gambar 48. 


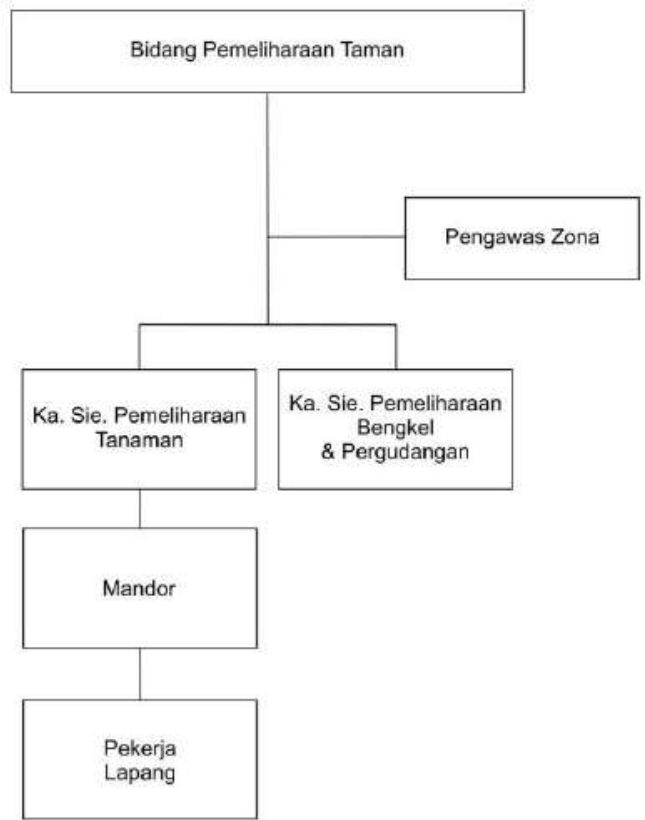

Gambar 48 Rekomendasi struktur organisasi

Jadwâl Kegiatan

Terdapat 8 kegiatan pemeliharaan yang penting untuk dilaksanakan, yaitu pembersihan dan penyapuan areal taman serta pembuangan sampah, pemangkasan semak dan tanaman penutup tanah (ground cover), pemangkasan rumput, penyiangan gulma, pencegahan hama dan penyakit, pemupukan ground cover dan perdu. pemupukan pohon, serta penyemprotan pestisida pada ground cover dan perdu을 Sistimatika jadwal pemeliharaan mempengaruhi efektivitas kerja dan efisiensi biaya. Rekomendasi kegiatan pemeliharaan beserta frekuensi dari masing-masing kegiatan disajikan pada Tabel 53.

Tabel 53 Rekomendasi kegiatan pemeliharaan

\begin{tabular}{|c|c|c|c|c|c|c|}
\hline \multirow{2}{*}{ No. } & \multirow{2}{*}{ Kegiatan Pemeliharaan } & \multicolumn{5}{|c|}{ Frekuensi* } \\
\hline & & 1 & 2 & 3 & 4 & 5 \\
\hline 1 & Pembersihan area taman & - & & & & \\
\hline 2 & Pembuangan sampah & $\bullet$ & & & & \\
\hline 3 & Pemangkasan semak dan ground cover & & - & & & \\
\hline 4 & Pemangkasan rumput & & - & & & \\
\hline 5 & Penyiangan gulma & & • & & & \\
\hline 6 & Pencegahan hama dan penyakit & & $\bullet$ & & & \\
\hline 7 & Pemupukan ground cover dan perdu & & & - & & \\
\hline 8 & Pemupukan pohon & & & & - & \\
\hline
\end{tabular}

*Keterangan: $1=$ harian, $2=$ bulanan, $3=$ triwulan, $4=$ semesteran, $5=$ insidental

\section{Tenaga Kerja}

Tenaga kerja yang dipekerjakan harus memiliki keterampilan dalam melakukan kegiatan pemeliharaan. Zona pemeliharaan dibagi berdasarkan beberapa titik lokasi sehingga jumlah tenaga kerja sesuai dengan kebutuhan, tidak berlebihan atau kurang (Arifin dan Arifin 2005). Jumlah tenaga kerja pemefiharaan harian dihitung berdasarkan perhitungan jam kerja perminggu dan 
perhitungan kebutuhan tenaga kerja (KTK). Untuk mengetahui kebutuhan jam kerja perminggu, diperlukan perhitungan hari orang kerja (HOK) selama satu tahun dengan rumus sebagai berikut,

$$
\mathrm{HOK}=\frac{\text { Kebutuhan waktu (jam) }}{8 \text { jam }}
$$

$$
\text { Jam kerja perminggu }=\frac{\mathrm{HOK} / \text { tahun } \mathrm{x} 8 \mathrm{orang} / \mathrm{jam} / \text { hari }}{52 \mathrm{jam} / \mathrm{minggu}}
$$

Kebutuhan hari orang kerja (HOK) harus mempertimbangkan kapasitas kerja (KK), jumlah tanaman atau luasan area dan frekuensi pelaksanaan kegiatan pemeliharaan. Luas rumput di Jalan Raya Pajajaran Segmen I adalah $200 \mathrm{~m}^{2}$. Luas ground cover dan semak seluas $236,5 \mathrm{~m}^{2}$. Luas perdu dan ground cover adalah $394,4 \mathrm{~m}^{2}$. Jumlah pohon adalah 222 pohon. Perhitungan HOK selama satu tahun di Jalan Raya Pajajaran disajikan pada Tabel 54.

\begin{tabular}{|c|c|c|c|c|c|c|c|}
\hline No. & Parameter & $\mathrm{KK}^{1}$ & Jumlah $^{2}$ & $\begin{array}{l}\text { Kebutuh- } \\
\text { an waktu } \\
\text { (jam) }\end{array}$ & $\begin{array}{l}\mathrm{HOK} / \\
\text { Hari }^{3}\end{array}$ & $\begin{array}{l}\text { Frekuen } \\
\text { si/ } \\
\text { Tahun }^{4} \\
\end{array}$ & $\begin{array}{l}\text { HOK/ } \\
\text { Tahun }\end{array}$ \\
\hline \pm 1 & Penyapuan rumput & 400,00 & 200,00 & 0,50 & 0,06 & 260 & 15,60 \\
\hline$\frac{72}{\frac{7}{7}}$ & $\begin{array}{l}\text { Pemangkasan } \\
\text { semak dan ground } \\
\text { cover }\end{array}$ & 10,00 & 236,50 & 23,65 & 2,95 & 12 & 35,40 \\
\hline$\frac{3}{y} 3$ & $\begin{array}{l}\text { Pemangkasan } \\
\text { rumput }\end{array}$ & 250,00 & 200,00 & 0,80 & 0,01 & 12 & 0,12 \\
\hline $\mathrm{O}_{4}$ & Penyiangan gulma & 40,00 & 406,4 & 10,16 & 1,27 & 12 & 15,24 \\
\hline $\begin{array}{l}\frac{6}{0} 5 \\
\stackrel{0}{3}\end{array}$ & $\begin{array}{l}\text { Penyemprotan } \\
\text { pestisida pada } \\
\text { ground cover dan } \\
\text { perdu }\end{array}$ & 500,00 & 394,4 & 0,78 & 0,10 & 12 & 1,20 \\
\hline 6 & $\begin{array}{l}\text { Penyemprotan } \\
\text { pestisida pada } \\
\text { pohon }\end{array}$ & 15,00 & 222 & 14,8 & 1,85 & 12 & 22,20 \\
\hline 7 & $\begin{array}{l}\text { Pemupukan pupuk } \\
\text { inorganik untuk } \\
\text { ground cover dan } \\
\text { perdu }\end{array}$ & 200,00 & 394,4 & 1,97 & 0,25 & 4 & 1,00 \\
\hline 0 & $\begin{array}{l}\text { Pemupukan pupuk } \\
\text { organik untuk } \\
\text { ground cover dan } \\
\text { perdu }\end{array}$ & 100,00 & 394,4 & 3,94 & 0,49 & 4 & 1,96 \\
\hline$\frac{109}{7}$ & $\begin{array}{l}\text { Pemupukan pupuk } \\
\text { inorganik untuk } \\
\text { pohon }\end{array}$ & 7,00 & 222 & 31,71 & 3,96 & 2 & 7,92 \\
\hline $\begin{array}{l}70 \\
7 . \\
\end{array}$ & $\begin{array}{l}\text { Pemupukan pupuk } \\
\text { organik untuk } \\
\text { pohon }\end{array}$ & 7,00 & 222 & 31,71 & 3,96 & 2 & 7,92 \\
\hline O & & & & & Total & & 108,56 \\
\hline
\end{tabular}

Tabel 54 Perhitungan HOK di Jalan Raya Pajajaran Segmen I

Mengacu pada Amalia (1993) dan Adrianan (1992) dalam Arifin dan Arifin (2005) dengan satuan $\mathrm{m}^{2} /$ jam untuk rumput, ground cover, semak, dan perdu, serta satuan pohon/jam untuk pohon $-2 \mathrm{~m}^{2}$ untuk rumput, ground cover, semak, dan perdu; pohon untuk pohon 3 Hari orang kerja (HOK) dengan ketentuan 8 jam/orang/hari ${ }^{-4}$ Perhitungan 260 hari kerja selama satu tahun (5 hari/ minggu) 
Berdasarkan hasil perhitungan, didapatkan jumlah HOK selama setahun adalah 108,56. Selanjutnya, dilakukan perhitungan jumlah jam kerja perminggu dan kebutuhan tenaga kerja (KTK) untuk mendapat jumlah tenaga kerja.

$$
\begin{aligned}
\text { Jam kerja perminggu } & =\frac{\mathrm{HOK} / \text { tahun } \times 8 \mathrm{orang} / \mathrm{jam} / \mathrm{hari}}{52 \mathrm{jam} / \mathrm{minggu}} \\
& =\frac{108,56 \mathrm{jam} / \mathrm{orang} / \mathrm{hari} \times 8 \mathrm{orang} \text { jam } / \mathrm{hari}}{52 \mathrm{jam} / \mathrm{minggu}} \\
& =16,7 \mathrm{jam} / \mathrm{minggu} \approx 17 \mathrm{jam} / \mathrm{minggu}
\end{aligned}
$$

$\mathrm{KTK}=\frac{\text { Jam kerja/minggu }}{\text { Jam kerja produkif/minggu }} \times \frac{\text { Efektivitas kerja optimum }}{\text { Efektivitas kerja lapang }}$

$$
\begin{aligned}
& =\frac{17 \mathrm{jam} / \mathrm{minggu}}{30 \mathrm{jam} / \mathrm{minggu}} \times \frac{100}{70} \\
& =0,81 \text { orang } \approx 1 \text { orang }
\end{aligned}
$$

Berdasarkan perhitungan, total jam kerja perminggu di Jalan Raya Pajajaran Segmen I sebanyak 17 jam dan jumlah pekerja yang dibutuhkan sesuai dengan beban kerja adalah 1 orang. Perhitungan KTK dilakukan dengan jumlah jam kërja produktif sebesar $30 \mathrm{jam} /$ minggu dan efektivitas pekerja sebesar $70 \%$. Selanjütnya, dilakukan perhitungan HOK selama satu tahun di Jalan Raya

\begin{tabular}{|c|c|c|c|c|c|c|c|}
\hline No. & Parameter & $\mathrm{KK}^{1}$ & Jumlah $^{2}$ & $\begin{array}{l}\text { Kebutuh- } \\
\text { an waktu } \\
\text { (jam) }\end{array}$ & $\begin{array}{l}\mathrm{HOK} / \\
\mathrm{Hari}^{3}\end{array}$ & $\begin{array}{l}\text { Frekuen } \\
\text { si/ } \\
\text { Tahun }^{4} \\
\end{array}$ & $\begin{array}{l}\mathrm{HOK} / \\
\text { Tahun }\end{array}$ \\
\hline 1 & Penyapuan rumput & 400,00 & 1000,00 & 2,5 & 0,31 & 260 & 80,60 \\
\hline 2 & $\begin{array}{l}\text { Pemangkasan } \\
\text { semak dan ground } \\
\text { cover }\end{array}$ & 10,00 & 165,00 & 16,5 & 2,06 & 12 & 24,72 \\
\hline 3 & $\begin{array}{l}\text { Pemangkasan } \\
\text { rumput }\end{array}$ & 250,00 & 1000,00 & 4 & 0,50 & 12 & 6,00 \\
\hline 4 & $\begin{array}{l}\text { Penyiangan gulma } \\
\text { (dengan kored }\end{array}$ & 40,00 & 187,00 & 4,68 & 0,59 & 12 & 7,08 \\
\hline 5 & $\begin{array}{l}\text { Penyemprotan } \\
\text { pestisida pada } \\
\text { gxound cover dan } \\
\text { (perdu }\end{array}$ & 500,00 & 157,00 & 0,31 & 0,04 & 12 & 0,48 \\
\hline 6 & $\begin{array}{l}\text { Penyemprotan } \\
\text { pestisida pada } \\
\text { pohon }\end{array}$ & 15,00 & 548,00 & 36,53 & 4,57 & 12 & 54,84 \\
\hline 7 & $\begin{array}{l}\text { Pèmupukan pupuk } \\
\text { Gorganik untuk } \\
\text { ground cover dan } \\
\text { perdu }\end{array}$ & 200,00 & 157,00 & 0,79 & 0,10 & 4 & 0,40 \\
\hline
\end{tabular}
Pajajaran Segmen II. Luas dari rumput yang dipelihara di Jalan Raya Pajajaran Segmen II adalah $1000 \mathrm{~m}^{2}$. Luas ground cover dan semak adalah $165 \mathrm{~m}^{2}$. Luas perduglan ground cover adalah $157 \mathrm{~m}^{2}$. Jumlah pohon di segmen ini sebanyak 548 pohon? Perhitungan HOK disajikan pada Tabel 55.

Tabel 55 Perhitungan HOK di Jalan Raya Pajajaran Segmen II 
Tabel 55 Perhitungan HOK di Jalan Raya Pajajaran Segmen II (lanjutan)

\begin{tabular}{|c|c|c|c|c|c|c|c|}
\hline No. & Parameter & $\mathrm{KK}^{1}$ & Jumlah $^{2}$ & $\begin{array}{l}\text { Kebutuh- } \\
\text { an waktu } \\
\text { (jam) }\end{array}$ & $\begin{array}{l}\mathrm{HOK} / \\
\text { Hari }^{3}\end{array}$ & $\begin{array}{l}\text { Frekuen } \\
\text { si/ } \\
\text { Tahun }^{4}\end{array}$ & $\begin{array}{l}\text { HOK/ } \\
\text { Tahun }\end{array}$ \\
\hline 8 & $\begin{array}{l}\text { Pemupukan pupuk } \\
\text { organik untuk } \\
\text { ground cover dan } \\
\text { perdu }\end{array}$ & 100,00 & 157,00 & 1,57 & 0,2 & 4 & 0,80 \\
\hline 9 & $\begin{array}{l}\text { Pemupukan pupuk } \\
\text { inorganik untuk } \\
\text { pohon }\end{array}$ & 7,00 & 548,00 & 78,29 & 9,79 & 2 & 19,58 \\
\hline$\frac{1}{10}^{10}$ & $\begin{array}{l}\text { Pemupukan pupuk } \\
\text { organik untuk } \\
\text { pohon }\end{array}$ & 7,00 & 548,00 & 78,29 & 9,79 & 2 & 19,58 \\
\hline$\frac{9}{6}$ & & & & & & Total & 213,28 \\
\hline
\end{tabular}

- Mengacu pada Amalia (1993) dan Adrianan (1992) dalam Arifin dan Arifin (2005) dengan satuan $\overline{\mathrm{m}}^{2} /$ jam untuk rumput, ground cover, semak, dan perdu, serta satuan pohon/jam untuk pohon $\mathrm{m}^{2}$ untuk rumput, ground cover, semak, dan perdu; pohon untuk pohon ${ }^{3}$ EIari orang kerja $(\mathrm{HOK})$ dengan ketentuan $8 \mathrm{jam} / \mathrm{orang} / \mathrm{hari}$ terhitungan 260 hari kerja selama satu tahun (5 hari/ minggu)

Berdasarkan hasil perhitungan, didapatkan jumlah HOK selama setahun sebanyak 213,28 . Selanjutnya, dilakukan perhitungan jumlah jam kerja perminggu dan kebutuhan tenaga kerja (KTK).

$$
\begin{aligned}
\text { Jam kerja perminggu } & =\frac{\mathrm{HOK} / \text { tahun } \times 8 \text { orang } / \text { jam } / \text { hari }}{52 \mathrm{jam} / \mathrm{minggu}} \\
& =\frac{213,28 \mathrm{jam} / \mathrm{orang} / \mathrm{hari} \times 8 \text { orang jam } / \mathrm{hari}}{52 \mathrm{jam} / \mathrm{minggu}} \\
& =32,81 \mathrm{jam} / \mathrm{minggu} \approx 33 \mathrm{jam} / \mathrm{minggu}
\end{aligned}
$$

$$
\begin{aligned}
\mathrm{KTK} & =\frac{\text { Jam kerja/minggu }}{\text { Jam kerja produkif/minggu }} \times \frac{\text { Efektivitas kerja optimum }}{\text { Efektivitas kerja lapang }} \\
& =\frac{33 \mathrm{jam} / \mathrm{minggu}}{30 \mathrm{jam} / \mathrm{minggu}} \times \frac{100}{70} \\
& =1,57 \mathrm{orang} \approx 2 \text { orang }
\end{aligned}
$$

Berdasarkan perhitungan, didapatkan total jam kerja perminggu sebanyak 33 jam dan jumlah pekerja 2 orang. Luas dari rumput di Jalan Raya Pajajaran Segmen III adalah $960 \mathrm{~m}^{2}$. Luas ground cover dan semak adalah 203,7 $\mathrm{m}^{2}$. Luas perdu dan ground cover adalah 165,2 $\mathrm{m}^{2}$. Jumlah pohon di segmen ini sebanyak 430 pohon. Perhitungan HOK selama satu tahun di Jalan Raya Pajajaran Segmen (III disajikan pada Tabel 56. 
Tabel 56 Perhitungan HOK di Jalan Raya Pajajaran Segmen III

\begin{tabular}{|c|c|c|c|c|c|c|c|}
\hline No. & Parameter & $\mathrm{KK}^{1}$ & Jumlah $^{2}$ & $\begin{array}{l}\text { Kebutuh- } \\
\text { an waktu } \\
\text { (jam) }\end{array}$ & $\begin{array}{l}\mathrm{HOK} / \\
\text { Hari }^{3}\end{array}$ & $\begin{array}{l}\text { Frekuen } \\
\text { si/ } \\
\text { Tahun }^{4}\end{array}$ & $\begin{array}{l}\text { HOK/ } \\
\text { Tahun }\end{array}$ \\
\hline 1 & Penyapuan rumput & 400,00 & 960,00 & 2.40 & 0,30 & 260 & 78,00 \\
\hline 2 & $\begin{array}{l}\text { Pemangkasan } \\
\text { semak dan ground } \\
\text { cover dengan } \\
\text { gunting pangkas }\end{array}$ & 10,00 & 203,70 & 20.30 & 2,54 & 12 & 30,48 \\
\hline 3 & $\begin{array}{l}\text { Pemangkasan } \\
\text { rumput }\end{array}$ & 250,00 & 960,00 & 3.84 & 0.48 & 12 & 5,76 \\
\hline 4 & $\begin{array}{l}\text { Penyiangan gulma } \\
\text { dengan kored }\end{array}$ & 40,00 & 210,20 & 5,26 & 0,66 & 12 & 7,92 \\
\hline 5 & $\begin{array}{l}\text { Penyemprotan } \\
\text { pestisida pada } \\
\text { ground cover dan } \\
\text { p̈erdu }\end{array}$ & 500,00 & 165,20 & 0,33 & 0,04 & 12 & 0,48 \\
\hline 6 & $\begin{array}{l}\text { Penyemprotan } \\
\text { pestisida pada } \\
\text { pohon }\end{array}$ & 15,00 & 430,00 & 28,67 & 3,58 & 12 & 42,96 \\
\hline 7 & $\begin{array}{l}\text { Pemupukan pupuk } \\
\text { i } \\
\text { grorganik untuk } \\
\text { ground cover dan } \\
\text { Derdu }\end{array}$ & 200,00 & 165,20 & 0,83 & 0,10 & 4 & 0,40 \\
\hline 8 & $\begin{array}{l}\text { Pemupukan pupuk } \\
\text { organik untuk } \\
\text { ground cover dan } \\
\text { perdu }\end{array}$ & 100,00 & 165,20 & 1,65 & 0,21 & 4 & 0,80 \\
\hline 9 & $\begin{array}{l}\text { Pemupukan pupuk } \\
\text { inorganik untuk } \\
\text { Pohon }\end{array}$ & 7,00 & 430,00 & 61,42 & 7,68 & 2 & 15,36 \\
\hline 10 & $\begin{array}{l}\text { Pemupukan pupuk } \\
\text { organik untuk } \\
\text { pohon }\end{array}$ & 7,00 & 430,00 & 61,42 & 7,68 & 2 & 15,36 \\
\hline
\end{tabular}

${ }^{1}$ Mengacu pada Amalia (1993) dan Adrianan (1992) dalam Arifin dan Arifin (2005) dengan satuan $\mathrm{m}^{2} / \mathrm{jam}$ untuk rumput, ground cover, semak, dan perdu, serta satuan pohon/jam untuk pohon ${ }^{2} \mathrm{~m}^{2}$ untuk rumput, ground cover, semak, dan perdu; pohon untuk pohon

${ }^{3}$ Hari orang kerja (HOK) dengan ketentuan 8 jam/orang/hari

${ }^{4}$ Perhitungan 260 hari kerja selama satu tahun (5 hari/ minggu)

$$
\begin{aligned}
& \text { Jam kerja perminggu }=\quad \text { HOK } / \text { tahun } \times 8 \text { orang/jam } / \text { hari } \\
& 52 \mathrm{jam} / \text { minggu } \\
& =201,56 \mathrm{jam} / \text { orang } / \text { hari } \times 8 \text { orang jam } / \text { hari } \\
& 52 \mathrm{jam} / \mathrm{minggu} \\
& =31 \mathrm{jam} / \text { minggu } \\
& \mathrm{KTK}=\frac{\text { Jam kerja/minggu }}{\text { Jam kerja produkif/minggu }} \times \frac{\text { Efektivitas kerja optimum }}{\text { Efektivitas kerja lapang }} \\
& =\frac{31 \mathrm{jam} / \mathrm{minggu}}{30 \mathrm{jam} / \mathrm{minggu}} \times \frac{100}{70} \\
& =1,03 \text { orang } \approx 1 \text { orang }
\end{aligned}
$$


Berdasarkan perhitungan, total jam kerja perminggu sebanyak 33 jam dan jumlah pekerja yang dibutuhkan sesuai dengan beban kerja adalah 2 orang. Selanjutnya dilakukan perhitungan HOK di Jalan Otto Iskandardinata. Vegetasi yang dipelihara pada tapak ini hanyalah pohon. Perhitungan HOK selama satu tahun di Jalan Otto Iskandardinata disajikan pada Tabel 57.

Tabel 57 Perhitungan HOK di Jalan Raya Otto Iskandardinata

\begin{tabular}{|c|c|c|c|c|c|c|c|}
\hline No. & Parameter & $\mathrm{KK}^{1}$ & Jumlah $^{2}$ & $\begin{array}{l}\text { Kebutuh- } \\
\text { an waktu } \\
\text { (jam) }\end{array}$ & $\begin{array}{c}\mathrm{HOK} / \\
\text { Hari }^{3}\end{array}$ & $\begin{array}{l}\text { Frekuen } \\
\text { si/ } \\
\text { Tahun }^{4}\end{array}$ & $\begin{array}{l}\text { HOK/ } \\
\text { Tahun }\end{array}$ \\
\hline$\frac{1}{\frac{1}{2}}$ & $\begin{array}{l}\text { Penyemprotan } \\
\text { pestisida pada } \\
\text { pohon }\end{array}$ & 15,00 & 30,00 & 2,00 & 0,25 & 12 & 3,00 \\
\hline $\begin{array}{l}\frac{3}{2} 2 \\
\frac{3}{3}\end{array}$ & $\begin{array}{l}\text { Pemupukan pupuk } \\
\text { inorganik untuk } \\
\text { pohon }\end{array}$ & 7,00 & 30,00 & 4,29 & 0,54 & 2 & 1,08 \\
\hline$\frac{\bar{\pi}}{\bar{\pi}}$ & $\begin{array}{l}\text { Pemupukan pupuk } \\
\text { organik untuk } \\
\text { pohon }\end{array}$ & 7,00 & 30,00 & 4,29 & 0,54 & 2 & 1,08 \\
\hline $\bar{\equiv}$ & & & & & Total & & 5,16 \\
\hline
\end{tabular}

Mengacu pada Amalia (1993) dan Adrianan (1992) dalam Arifin dan Arifin (2005) dengan satuan $\overline{\mathrm{m}}^{2} / \mathrm{jam}$ untuk rumput, ground cover, semak dan perdu, serta satuan pohon/jam untuk pohon ${ }^{2} \mathrm{~m}^{2}$ untuk rumput, ground cover, semak dan perdu; pohon untuk pohon 3 Hari orang kerja (HOK) dengan ketentuan 8 jam/orang/hari

${ }^{4}$ Perhitungan 260 hari kerja selama satu tahun (5 hari/ minggu)

Berdasarkan hasil perhitungan, didapatkan jumlah HOK selama setahun sebanyak 5,16. Selanjutnya, dilakukan perhitungan jumlah jam kerja perminggu đan kebutuhan tenaga kerja (KTK).

$$
\begin{aligned}
& \text { Jam kerja perminggu }=\frac{\text { HOK } / \text { tahun } \times 8 \text { orang/jam } / \text { hari }}{52 \mathrm{jam} / \text { minggu }} \\
& =\underline{5,16 \mathrm{jam} / \text { orang/hari } \mathrm{x} 8 \text { orang jam/hari }} \\
& 52 \mathrm{jam} / \mathrm{minggu} \\
& =0,79 \mathrm{jam} / \mathrm{minggu} \approx 0,8 \mathrm{jam} / \mathrm{minggu} \\
& \mathrm{KTK}=\frac{\text { Jam kerja/minggu }}{\text { Jam kerja produkif/minggu }} \times \frac{\text { Efektivitas kerja optimum }}{\text { Efektivitas kerja lapang }} \\
& =\frac{0,8 \mathrm{jam} / \text { minggu }}{30 \mathrm{jam} / \mathrm{minggu}} \times \frac{100}{70} \\
& =0,03 \text { orang } \approx 1 \text { orang }
\end{aligned}
$$

Berdasarkan perhitungan, total jam kerja perminggu di Jalan Otto Iskandardinata sebanyak 0,8 jam dan jumlah pekerja yang dibutuhkan sesuai dengan beban kerja adalah 1 orang. Selanjutnya, dilakukan perhitungan HOK di jalur hijau Jalan Bina Marga yang meliputi taman sudut dan jalur hijau tepi jalan. Euas ground cover dan semak yang dipelihara adalah $49 \mathrm{~m}^{2}$. Luas perdu dan ground cover adalah $25,3 \mathrm{~m}^{2}$. Jumlah pohon di segmen ini sebanyak 41 pohon. 
Perhitungan HOK selama satu tahun di taman sudut dan jalur hijau tepi Jalan Bina Marga disajikan pada Tabel 58.

Tabel 58 Perhitungan HOK di Jalan Bina Marga

\begin{tabular}{|c|c|c|c|c|c|c|c|}
\hline No. & Parameter & $\mathrm{KK}^{1}$ & Jumlah $^{2}$ & $\begin{array}{l}\text { Kebutuh- } \\
\text { an waktu } \\
\text { (jam) }\end{array}$ & $\begin{array}{l}\mathrm{HOK} / \\
\mathrm{Hari}^{3}\end{array}$ & $\begin{array}{l}\text { Frekuen } \\
\text { si/ } \\
\text { Tahun }^{4}\end{array}$ & $\begin{array}{l}\text { HOK/ } \\
\text { Tahun }\end{array}$ \\
\hline 1 & $\begin{array}{l}\text { Pemangkasan } \\
\text { semak dan ground } \\
\text { cgver dengan } \\
\text { gunting pangkas }\end{array}$ & 10,00 & 49,10 & 4,91 & 0,61 & 12 & 7,36 \\
\hline 2 & $\begin{array}{l}\text { Penyiangan gulma } \\
\text { dengan kored }\end{array}$ & 40,00 & 57,90 & 1,45 & 0,18 & 12 & 2,17 \\
\hline 3 & $\begin{array}{l}\text { Penyemprotan } \\
\text { pestisida pada } \\
\text { ground cover dan } \\
\text { perdu }\end{array}$ & 500,00 & 25,30 & 0,05 & 0,01 & 12 & 0,08 \\
\hline 4 & 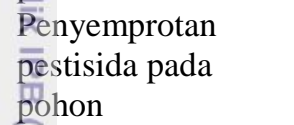 & 15,00 & 41 & 2,73 & 0,34 & 12 & 4,1 \\
\hline 5 & $\begin{array}{l}\text { Pemupukan pupuk } \\
\text { inorganik untuk } \\
\text { ground cover dan } \\
\text { perdu }\end{array}$ & 200,00 & 25,30 & 0,12 & 0,01 & 4 & 0,06 \\
\hline 6 & $\begin{array}{l}\text { Pemupukan pupuk } \\
\text { organik untuk } \\
\text { ground cover dan } \\
\text { perdu }\end{array}$ & 100,00 & 25,30 & 0,23 & 0,03 & 4 & 0,12 \\
\hline 7 & $\begin{array}{l}\text { Bemupukan pupuk } \\
\text { inorganik untuk } \\
\text { pohon }\end{array}$ & 7,00 & 41 & 5,86 & 0,73 & 2 & 1,46 \\
\hline \multirow[t]{2}{*}{8} & $\begin{array}{l}\text { Pemupukan pupuk } \\
\text { organik untuk } \\
\text { pohon }\end{array}$ & 7,00 & 41 & 5,86 & 0,73 & 2 & 1,46 \\
\hline & & & & & Total & & 16,83 \\
\hline
\end{tabular}

${ }^{\mathrm{T}}$ Mengacu pada Amalia (1993) dan Adrianan (1992) dalam Arifin dan Arifin (2005) dengan satuan $\mathrm{m}^{2} / \mathrm{jam}$ untuk rumput, ground cover, semak, dan perdu, serta satuan pohon/jam untuk pohon

${ }^{2} \mathrm{~m}^{2}$ untuk rumput, ground cover, semak, dan perdu; pohon untuk pohon

${ }^{3}$ Hari orang kerja (HOK) dengan ketentuan 8 jam/orang/hari

${ }^{4}$ Perhitungan 260 hari kerja selama satu tahun (5 hari/ minggu)

$$
\begin{aligned}
& \text { Jam kerja perminggu }=\frac{\mathrm{HOK} / \text { tahun } \times 8 \mathrm{orang} / \mathrm{jam} / \mathrm{hari}}{52 \mathrm{jam} / \mathrm{minggu}} \\
& =\underline{16,83 \mathrm{jam} / \text { orang/hari } \times 8 \text { orang jam/hari }} \\
& 52 \mathrm{jam} / \mathrm{minggu} \\
& =2,58 \mathrm{jam} / \mathrm{minggu} \approx 3 \mathrm{jam} / \mathrm{minggu} \\
& \text { KTK }=\frac{\text { Jam kerja/minggu }}{\text { Jam kerja produkif/minggu }} \times \frac{\text { Efektivitas kerja optimum }}{\text { Efektivitas kerja lapang }} \\
& =\frac{3 \mathrm{jam} / \mathrm{minggu}}{30 \mathrm{jam} / \mathrm{minggu}} \times \frac{100}{70} \\
& =0,14 \text { orang } \approx 1 \text { orang }
\end{aligned}
$$


Berdasarkan perhitungan, total jam kerja perminggu di Jalan Bina Marga sebanyak 3 jam dan jumlah pekerja yang dibutuhkan sesuai dengan beban kerja adalah 1 orang. Selanjutnya, dilakukan perhitungan HOK di Jalan Padi. Luas ground cover dan semak pada tapak adalah $3,1 \mathrm{~m}^{2}$. Luas perdu dan ground cover adalah $2,1 \mathrm{~m}^{2}$. Jumlah pohon di segmen ini sebanyak 29 pohon. Perhitungan HOK di Jalan Padi disajikan pada Tabel 59.

Tabel 59 Perhitungan HOK di Jalan Padi

\begin{tabular}{|c|c|c|c|c|c|c|c|}
\hline No. & Parameter & $\mathrm{KK}^{1}$ & Jumlah $^{2}$ & $\begin{array}{l}\text { Kebutuh- } \\
\text { an waktu } \\
\text { (jam) }\end{array}$ & $\begin{array}{l}\mathrm{HOK} / \\
\mathrm{Hari}^{3}\end{array}$ & $\begin{array}{l}\text { Frekuen } \\
\text { si/ } \\
\text { Tahun }^{4} \\
\end{array}$ & $\begin{array}{l}\mathrm{HOK} / \\
\text { Tahun }\end{array}$ \\
\hline 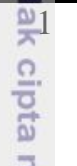 & $\begin{array}{l}\text { Pemangkasan } \\
\text { semak dan ground } \\
\text { cover dengan } \\
\text { gunting pangkas }\end{array}$ & 10,00 & 2,7 & 0,270 & 0,034 & 12 & 0,408 \\
\hline 严2 & $\begin{array}{l}\text { Penyiangan gulma } \\
\text { dengan kored }\end{array}$ & 40,00 & 3,10 & 0,078 & 0,010 & 12 & 0,120 \\
\hline 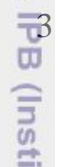 & $\begin{array}{l}\text { Penyemprotan } \\
\text { pestisida pada } \\
\text { ground cover dan } \\
\text { perdu }\end{array}$ & 500,00 & 2,10 & 0,004 & 0,001 & 12 & 0,012 \\
\hline $\begin{array}{l}\overrightarrow{\vec{c}} 4 \\
\stackrel{\vec{F}}{\square} \\
\stackrel{0}{7}\end{array}$ & $\begin{array}{l}\text { Penyemprotan } \\
\text { pestisida pada } \\
\text { pohon }\end{array}$ & 15,00 & 29,00 & 1,933 & 0,242 & 12 & 2,904 \\
\hline $\begin{array}{l}\frac{1}{25} \\
\frac{3}{2} \\
\frac{0}{3} \\
0 \\
0\end{array}$ & $\begin{array}{l}\text { Pemupukan pupuk } \\
\text { inorganik untuk } \\
\text { ground cover dan } \\
\text { perdu }\end{array}$ & 200,00 & 2,10 & 0,011 & 0,001 & 4 & 0,004 \\
\hline$\stackrel{6}{\circ} 6$ & $\begin{array}{l}\text { Pemupukan pupuk } \\
\text { organik untuk } \\
\text { ground cover dan } \\
\text { perdu }\end{array}$ & 100,00 & 2,10 & 0,021 & 0,002 & 4 & 0,008 \\
\hline 7 & $\begin{array}{l}\text { Pemupukan pupuk } \\
\text { inorganik untuk } \\
\text { pohon }\end{array}$ & 7,00 & 29,00 & 4,143 & 0,518 & 2 & 1,036 \\
\hline 8 & $\begin{array}{l}\text { Pemupukan pupuk } \\
\text { organik untuk } \\
\text { pohon }\end{array}$ & 7,00 & 29,00 & 4,143 & 0,518 & 2 & 1,036 \\
\hline
\end{tabular}

${ }^{1}$ Mengacu pada Amalia (1993) dan Adrianan (1992) dalam Arifin dan Arifin (2005) dengan satuan $\mathrm{m}^{2} /$ jam untuk rumput, ground cover, semak, dan perdu, serta satuan pohon/jam untuk pohon

${ }^{2} \mathrm{~m}^{2}$ untuk rumput, ground cover, semak, dan perdu; pohon untuk pohon

3Hari orang kerja (HOK) dengan ketentuan 8 jam/orang/hari

$(4$ Perhitungan 260 hari kerja selama satu tahun (5 hari/ minggu)

$$
\begin{aligned}
\text { Jam kerja perminggu } & =\frac{\mathrm{HOK} / \text { tahun } \times 8 \text { orang/jam } / \text { hari }}{52 \mathrm{jam} / \mathrm{minggu}} \\
& =\frac{5,636 \mathrm{jam} / \mathrm{orang} / \mathrm{hari} \times 8 \text { orang jam } / \text { hari }}{52 \mathrm{jam} / \mathrm{minggu}} \\
& =0,87 \mathrm{jam} / \mathrm{minggu} \approx 1 \mathrm{jam} / \text { minggu }
\end{aligned}
$$




$$
\begin{aligned}
\mathrm{KTK} & =\frac{\text { Jam kerja/minggu }}{\text { Jam kerja produkif/minggu }} \times \frac{\text { Efektivitas kerja optimum }}{\text { Efektivitas kerja lapang }} \\
& =\frac{1 \mathrm{jam} / \mathrm{ming} \mathrm{u}}{30 \mathrm{jam} / \mathrm{minggu}} \times \frac{100}{70} \\
& =0,05 \text { orang } \approx 1 \text { orang }
\end{aligned}
$$

Berdasarkan perhitungan, total jam kerja perminggu sebanyak 1 jam dan jumlah pekerja yang dibutuhkan sesuai dengan beban kerja adalah 1 orang. Selanjutnya, dilakukan perhitungan HOK di Jalan Padi. Luas rumput pada tapak adalah $400 \mathrm{~m}^{2}$. Jumlah pohon di segmen ini sebanyak 32 pohon. Perhitungan

\begin{tabular}{|c|c|c|c|c|c|c|c|}
\hline No. & Parameter & $\mathrm{KK}^{1}$ & Jumlah $^{2}$ & $\begin{array}{l}\text { Kebutuh- } \\
\text { an waktu } \\
\text { (jam) }\end{array}$ & $\begin{array}{c}\mathrm{HOK} / \\
\text { Hari }^{3}\end{array}$ & $\begin{array}{l}\text { Frekuen } \\
\text { si/ } \\
\text { Tahun }^{4}\end{array}$ & $\begin{array}{l}\text { HOK/ } \\
\text { Tahun }\end{array}$ \\
\hline 1 & Penyapuan rumput & 400,00 & 400,00 & 1 & 0,13 & 260 & 32,50 \\
\hline 2 & $\begin{array}{l}\text { Pemangkasan } \\
\text { reumput }\end{array}$ & 250,00 & 400,00 & 1,6 & 0,20 & 12 & 2,40 \\
\hline 3 & $\begin{array}{l}\text { Penyemprotan } \\
\text { pestisida pada } \\
\text { pohon }\end{array}$ & 15,00 & 32,00 & 2,13 & 0,27 & 12 & 32,00 \\
\hline 4 & $\begin{array}{l}\text { Pemupukan pupuk } \\
\text { p̈organik untuk } \\
\text { p̈ohon }\end{array}$ & 7,00 & 32,00 & 4,57 & 0,57 & 2 & 1,14 \\
\hline 5 & $\begin{array}{l}\text { Pemupukan pupuk } \\
\text { grganik untuk } \\
\text { pohon }\end{array}$ & 7,00 & 32,00 & 4,57 & 0,57 & 2 & 1,14 \\
\hline
\end{tabular}
HOK di Jalan Pakuan disajikan pada Tabel 60.

Tabel 60 Perhitungan HOK di Jalan Pakuan

${ }^{1}$ Mengacu pada Amalia (1993) dan Adrianan (1992) dalam Arifin dan Arifin (2005) dengan satuan $\mathrm{m}^{2} / \mathrm{jam}$ untuk rumput, ground cover, semak, dan perdu, serta satuan pohon/jam untuk pohon

${ }^{2} \mathrm{~m}^{2}$ untuk rumput, ground cover, semak, dan perdu; pohon untuk pohon

${ }^{3}$ Hari orang kerja (HOK) dengan ketentuan 8 jam/orang/hari

${ }^{4}$ Perhitungan 260 hari kerja selama satu tahun (5 hari/ minggu)

Berdasarkan hasil perhitungan, didapatkan jumlah HOK selama setahun di Jalan Pakuan sebanyak 40,39.

$$
\begin{aligned}
& =\frac{52 \mathrm{jam} / \mathrm{minggu}}{50,39 \mathrm{jam} / \mathrm{orang} / \mathrm{hari} \times 8 \text { orang jam } / \mathrm{hari}} \\
& 52 \mathrm{jam} / \mathrm{minggu} \\
& =6,21 \mathrm{jam} / \mathrm{minggu} \approx 7 \mathrm{jam} / \text { minggu }
\end{aligned}
$$

KTK $=\frac{\text { Jam kerja/minggu }}{\text { Jam kerja produkif/minggu }} \times \frac{\text { Efektivitas kerja optimum }}{\text { Efektivitas kerja lapang }}$

$$
=\frac{7 \mathrm{jam} / \mathrm{minggu}}{30 \mathrm{jam} / \mathrm{minggu}} \times \frac{100}{70}
$$$$
=0,33 \text { orang } \approx 1 \text { orang }
$$ 
Berdasarkan perhitungan, total jam kerja perminggu di Jalan Pakuan adalah 7 jam dan jumlah pekerja yang dibutuhkan sesuai dengan beban kerja adalah 1 orang. Selanjutnya, dilakukan perhitungan HOK di median Tol Jagorawi. Jumlah pohoh di median sebanyak 75 pohon. Luas ground cover dan semak adalah $384,02 \mathrm{~m}^{2}$. Luas perdu dan ground cover adalah $339,02 \mathrm{~m}^{2}$. Perhitungan HOK disajikan pada Tabel 61.

Tabel 61 Perhitungan HOK di median Tol Jagorawi

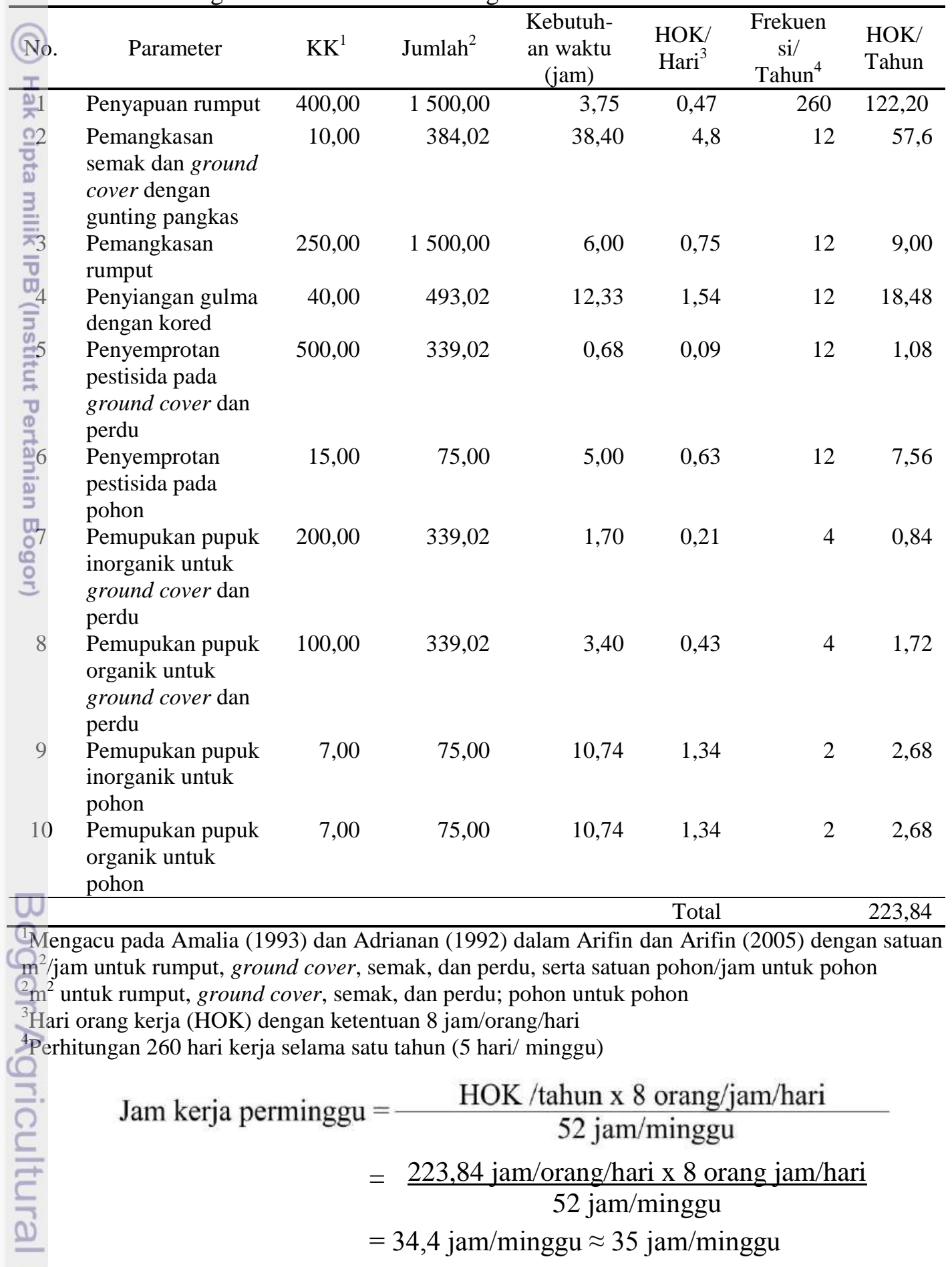




$$
\begin{aligned}
\mathrm{KTK} & =\frac{\text { Jam kerja/minggu }}{\text { Jam kerja produkif/minggu }} \times \frac{\text { Efektivitas kerja optimum }}{\text { Efektivitas kerja lapang }} \\
& =\frac{35 \mathrm{jam} / \text { minggu }}{30 \mathrm{jam} / \mathrm{minggu}} \times \frac{100}{70} \\
& =1,67 \text { orang } \approx 2 \text { orang }
\end{aligned}
$$

Berdasarkan perhitungan, total jam kerja perminggu sebanyak 35 jam dan jumlah pekerja yang dibutuhkan sesuai dengan beban kerja adalah 2 orang. Berdasarkan perhitungan HOK di delapan titik lokasi, jumlah jam kerja di Jalan Padi, Jalan Pakuan, Jalan Bina Marga dan Jalan Otto Iskandardinata kurang dari 30 jam/minggu. oleh sebab itu, pemeliharaan di keempat titik lokasi ini direkomendasikan menjadi satu zona. Zona tersebut dapat dipelihara oleh satu pekerja lapang, sehingga kegiatan pemeliharaan berjalan efektif dan efisien. Secarækeseluruhan, jumlah pekerja lapang yang dibutuhkan adalah 6 orang.

\section{Alat dān Bahan}

đal dan bahan yang direkomendasikan secara umum telah dimiliki oleh pihak $\overline{\bar{p}}$ engelola. Rekomendasi kebutuhan alat dan bahan disajikan pada Tabel 62.

Tabel 62 Kebutuhan alat dan bahan pemeliharaan selama satu tahun

\begin{tabular}{cccc}
\hline No. & \multicolumn{1}{c}{ Alat dan Bahan } & Rekomendasi & Satuan \\
\hline 1 & Cangkul & 6 & Buah \\
2 & Garpu tanah & 6 & Buah \\
3 & Mesin pemangkas rumput dorong & 1 & Unit \\
4 & Garang & 6 & Buah \\
5 & Gunting pangkas & 6 & Buah \\
6 & Kored & 6 & Buah \\
7 & Pengki & 6 & Buah \\
8 & Sapu lidi & 6 & Buah \\
9 & Chainsaw & 1 & Buah \\
10 & Seragam operator & 6 & Unit \\
11 & Sarung tangan & 6 & Unit \\
12 & Masker & 6 & Buah \\
13 & Tempat sampah & 6 & Unit \\
14 & Bensin & 14,4 & Liter \\
15 & OPupuk kandang & 680 & Kg \\
16 & Oupuk urea & 340 & Kg \\
17 & GHerbisida & 12 & Liter \\
\hline
\end{tabular}

Sumber; berdasarkan wawancara dan hasil pengamatan

\section{Rencana Anggaran Biaya}

ZRencana anggaran biaya yang direkomendasikan terdiri atas rencana anggaran biaya tahunan dalam kegiatan pemeliharaan, rencana anggaran penggunaan alat, dan bahan pemeliharaan. Secara keseluruhan, rencana anggaran biayapemeliharaan dihitung berdasarkan beban kerja di lapang dan rekomendasi kegiatan pemeliharaan (Tabel 63). 
Tabel 63 Anggaran biaya pemeliharaan selama satu tahun

\begin{tabular}{|c|c|c|c|c|}
\hline No. & Parameter & $\begin{array}{l}\mathrm{HOK} / \\
\text { Tahun }\end{array}$ & $\begin{array}{c}\text { Harga } \\
\text { HOK }^{1} \\
\text { (Rp) }\end{array}$ & $\begin{array}{l}\text { Harga HOK } \\
\text { Setahun (Rp) }\end{array}$ \\
\hline 1 & Pemangkasan rumput & 328,90 & 120000 & 39468000,00 \\
\hline 2 & $\begin{array}{l}\text { Pemangkasan semak dan ground } \\
\text { cover }\end{array}$ & 153,96 & 120000 & 18475200 \\
\hline 3 & Pemangkasan rumput & 23,80 & 120000 & 2793600,00 \\
\hline 4 & Penyiangan gulma & 51,73 & 120000 & 6207600,00 \\
\hline (3) & $\begin{array}{l}\text { Penyemprotan pestisida pada ground } \\
\text { cover dan perdu }\end{array}$ & $\begin{array}{r}2 \\
, 13\end{array}$ & 120000 & 255600,00 \\
\hline$\frac{T}{20} 6$ & Penyemprotan pestisida pada pohon & 169,56 & 120000 & 20347200,00 \\
\hline$\frac{\pi}{n} 7$ & $\begin{array}{l}\text { Pemupukan pupuk inorganik untuk } \\
\text { ground cover dan perdu }\end{array}$ & 2,71 & 120000 & 325200,00 \\
\hline 8 & $\begin{array}{l}\text { Pemupukan pupuk organik ground } \\
\text { cover dan perdu }\end{array}$ & 5,41 & 120000 & 649200,00 \\
\hline$\frac{\bar{x}}{\bar{\nabla}}$ & $\begin{array}{l}\text { Pemupukan pupuk inorganik untuk } \\
\text { pohon }\end{array}$ & 49,63 & 120000 & 5956320,00 \\
\hline$\frac{1}{\overline{\bar{G}}} 0$ & $\begin{array}{l}\text { Pemupukan pupuk organik untuk } \\
\text { pohon }\end{array}$ & 49,63 & 120000 & 5956320,00 \\
\hline$\stackrel{\#}{\rightleftarrows}$ & & Total & & 96225240,00 \\
\hline
\end{tabular}

Berdasarkan perhitungan, didapatkan anggaran biaya kegiatan pemeliharaan sebesar Rp 96.225.240,00/tahun dengan jumlah hari kerja sebanyak 22 hari kerja/bulan. Selanjutnya, dilakukan perhitungan anggaran biaya pengadaan alat dan bahan (Tabel 64 dan 65).

Tabel 64 Anggaran pengadaan alat selama satu tahun

\begin{tabular}{|c|c|c|c|c|c|c|c|}
\hline No. & Alat & Jumlah & Satuan & $\begin{array}{c}\text { Harga } \\
\text { Satuan } \\
(\mathrm{Rp})\end{array}$ & $\begin{array}{l}\text { Harga } \\
\text { Total } \\
(\mathrm{Rp})\end{array}$ & $\begin{array}{c}\text { Masa } \\
\text { Susut } \\
\text { Alat } \\
\text { (tahun) } \\
\end{array}$ & $\begin{array}{l}\text { Harga/Tahun } \\
\text { (Rp) }\end{array}$ \\
\hline 1 & Cangkul & 6 & buah & 25000 & 150000 & 0,083 & 5722900 \\
\hline 2 & $\begin{array}{l}\text { Garpu } \\
\text { tanah }\end{array}$ & 6 & buah & 25000 & 150000 & 0,500 & 300000 \\
\hline ए & $\begin{array}{l}\text { Mesin } \\
\text { pemangkas } \\
\text { rumput } \\
\text { dorong }\end{array}$ & 1 & unit & 2500000 & 2500000 & 3,000 & 833400 \\
\hline $\mathrm{O}_{4}$ & Parang & 6 & buah & 50000 & 300000 & 0,500 & 600000 \\
\hline$\stackrel{\mathrm{O}}{\mathrm{O}} 5$ & $\begin{array}{l}\text { Gunting } \\
\text { pangkas }\end{array}$ & 6 & buah & 200000 & 1200000 & 0,500 & 2400000 \\
\hline 6 & Kored & 6 & buah & 10000 & 60000 & 0,500 & 120000 \\
\hline & Pengki & 6 & buah & 20000 & 120000 & 0,083 & 1445400 \\
\hline 8 & Sapu lidi & 6 & buah & 20000 & 120000 & 0,083 & 1445400 \\
\hline 9 & Chainsaw & 1 & buah & 1750000 & 1750000 & 3,000 & 583400 \\
\hline$\frac{90}{\rightleftarrows}$ & $\begin{array}{l}\text { Seragam } \\
\text { operator }\end{array}$ & 6 & unit & 150000 & 900000 & 0,500 & 1800000 \\
\hline$\frac{51}{9}$ & $\begin{array}{l}\text { Sarung } \\
\text { tangan }\end{array}$ & 6 & unit & 20000 & 120000 & 0,083 & 1445400 \\
\hline
\end{tabular}


Tabel 64 Anggaran pengadaan alat selama satu tahun (lanjutan)

\begin{tabular}{|c|c|c|c|c|c|c|c|}
\hline No. & Alat & Jumlah & Satuan & $\begin{array}{c}\text { Harga } \\
\text { Satuan } \\
(\mathrm{Rp})\end{array}$ & $\begin{array}{c}\text { Harga } \\
\text { Total } \\
(\mathrm{Rp})\end{array}$ & $\begin{array}{c}\text { Masa } \\
\text { Susut } \\
\text { Alat } \\
\text { (tahun) }\end{array}$ & $\begin{array}{l}\text { Harga/Tahun } \\
\quad(\mathrm{Rp})\end{array}$ \\
\hline 12 & Masker & 6 & buah & 20000 & 120000 & 0,083 & 1445400 \\
\hline 13 & $\begin{array}{l}\text { Tempat } \\
\text { sampah }\end{array}$ & 6 & unit & 100000 & 600000 & 1,000 & 600000 \\
\hline
\end{tabular}

Tabel 65 Anggaran pengadaan bahan pemeliharaan selama satu tahun

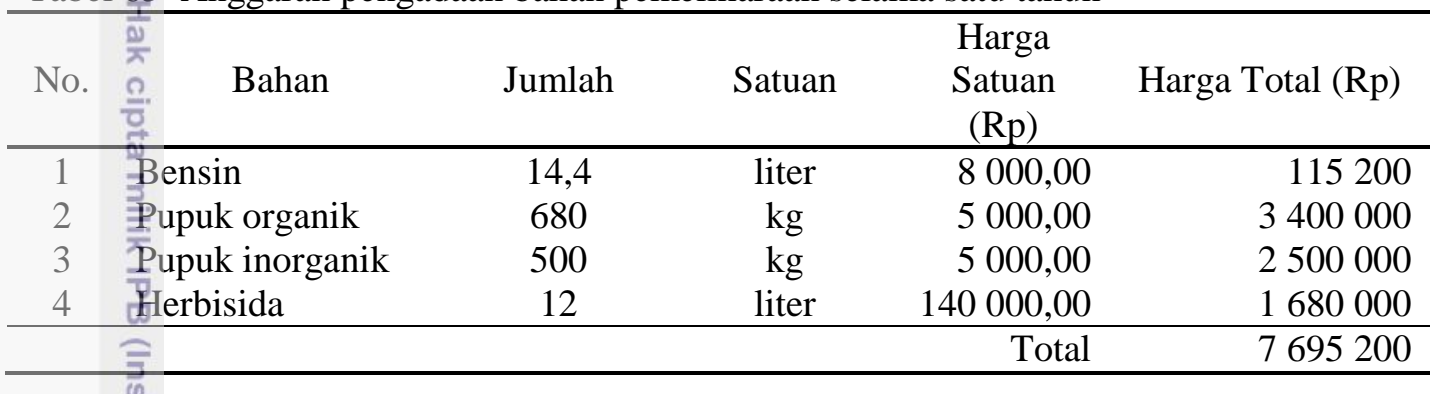

Total biaya alat dan bahan yang dibutuhkan dalam pemeliharaan jalur hijau jjalan di Kelurahan Baranangsiang selama satu tahun adalah $\mathrm{Rp}$ 17.780.200,00 dengan rincian anggaran penggunaan alat sebesar $\mathrm{Rp}$ 10.085.000,00 dan anggaran penggunaan bahan sebesar Rp 7.695.200,00. Total anggafan biaya dari kegiatan pemeliharaan dan anggaran pengadaan alat serta bahandalah Rp 114.005.440,00.

\section{SIMPULAN DAN SARAN}

\section{Simpulan}

Kegiatan penelitian ini menambah pengetahuan dalam bidang Arsitektur Lanskap, khususnya di bidang pengelolaan lanskap. Setiap titik lokasi memiliki ruas jalur hijau yang berbeda-beda. Keragaman vegetasi jalur hijau di setiap lokasi berbeda-beda. Keragaman paling tinggi terdapat pada jalur hijau Jalan Raya Pajajaran Segmen I, sedangkan keragaman paling rendah terdapat pada jalur hijau Jalan Otto Iskandardinata.

Pengguna jalan memberikan penilaian tertinggi dalam aspek kebersihan di jalur hijau Jalan Raya Pajajaran Segmen I dan Jalan Bina Marga. Keberadaan nursery atau pedagang tanaman hias di jalur hijau Jalan Bina Marga memberikan dampak positif dan negatif. Keberadaan nursery menambah nilai estetika dan kebersihan dari tapak, tetapi sebagian besar nursery menggunakan jalur pejalan kaki sebagai bagian dari tempat berjualan. Hal ini mengganggu kenyamanan pengguna jalan. Dinas Kebersihan dan Pertamanan harus memberikan sanksi kepada-nursery yang melanggar aturan.

CPengguna jalan memberikan penilaian tertinggi dalam aspek keamanan dan Rènyamanan di jalur hijau Jalan Pakuan. Pengguna jalan memberikan 
penilaian tertinggi dalam aspek fasilitas di jalur hijau Jalan Raya Pajajaran Segmen I dan Pakuan. Pengguna jalan memberikan penilaian tertinggi dalam aspek keindahan di median Tol Jagorawi.

Pohon dengan fungsi peredam kebisingan hanya terdapat pada Jalan Raya Pajajaran Segmen III, Jalan Otto Iskandardinata, Jalan Bina Marga, dan Jalan Padi. Pohon dengan fungsi pemecah angin terdapat di semua titik lokasi kecuali Tol Jagorawi. Pohon dengan fungsi peneduh dapat dijumpai di semua lokasi kecuali Tol Jagorawi. Pohon dengan fungsi pengarah dapat dijumpai di setiap tokasi. Pohon dengan fungsi border hanya terdapat di Jalan Padi, Jalan Pakuan, Jalan Bina Marga, dan Jalan Raya Pajajaran Segmen I s.d. III.

Kondisi hardscape yang tergolong baik terdapat di Jalan Otto Iskandardinata. Sebagian besar site structure tergolong cukup baik. Secara keseluruhan, diperlukan penambahan tempat sampah di semua lokasi. Sebagian besar halte tidak lagi digunakan akibat vandalisme. Dinas Kebersihan dan Pertamanan harus meningkatkan pengawasan terhadap tapak. Secara keseluruhan, Keberadaan tanaman di median jalan tidak mengganggu jarak pandang pengguna kendaraan bermotor.

Terdapat perbedaan frekuensi kegiatan pemeliharaan antara kondisi di papang dengan literatur. Kondisi pemeliharaan jalur hijau saat ini masih đifokuskan pada area Tol Jagorawi, Jalan Raya Pajajaran, dan Taman Sudut Bina Marga. Kurangnya keterampilan pekerja lapang menjadi salah satu kendala dalam Kegiatan pemeliharaan. Kegiatan pemeliharaan perlu dibagi menjadi beberapa żona dan keterampilan para pekerja lapang perlu ditingkatkan agar pemeliharaan Ëerlangsung efektif dan efisien.

एँ Berdasarkan analisis pengelolaan dengan metode SWOT, didapatkan enam alternatif strategi pengelolaan. Alternatif strategi tersebut diharapkan dapat membantu pihak pengelola dalam mempertahankan bahkan meningkatkan kegiatan pengelolaan yang telah dilaksanakan. Salah satu alternatif strategi yang dihasilkan adalah penyusunan rencana pengelolaan yang mencakup aspek struktur organisasi, tenaga kerja, jadwal pengelolaan, pengadaan alat dan bahan, serta anggaran biaya.

\section{Saran}

Saran yang diberikan kepada Dinas Kebersihan dan Pertamanan selaku pihak pengelola jalur hijau jalan di Kelurahan Baranangsiang adalah sebagai berikut:

melakukan pengawasan dan koordinasi rutin terkait kondisi hardscape dan site structure dengan dinas-dinas terkait;

2. menyusun kembali rencana pengelolaan dengan memperhatikan aspek tenaga kerja, jadwal kegiatan pemeliharaan, alat dan bahan serta anggaran biaya agar sesuai dengan beban kerja;

meningkatkan kuantitas dan kualitas sumber daya manusia serta alat dan bahan dengan diiringi peningkatan kinerja pemeliharaan dari pihak pengelola; mempertahankan dan meningkatkan kerja sama dengan instansi pemerintah, pihak swasta serta masyarakat dalam mengoptimalkan upaya pengelolaan jalur hijau jalan di Kelurahan Baranangsiang. 


\section{DAFTAR PUSTAKA}

Aram A. 2010. Effective savety factors on horizontal curves on two-lane highways. J. Applied Sci. 10(22): 2815-2820.

Arifin HS, Arifin NHS. 2005. Pemeliharaan Taman. Ed Revisi. Jakarta (ID): Penebar Swadaya.

Arifin HS, Arifin NHS, Damayanti VD, Munandar A, Pramukanto Q. 2008. Sampoerna Hijau Kotaku Hijau: Buku Panduan Penataan Taman Umum, Penataan Tanaman, Penanganan Sampah dan Pemberdayaan Masyarakat. Jakarta (ID).

Booth NK. 1983. Basic Elements of Landscape Architectural Design. Illinois (US): Waveland Press, Inc.

[Dept. PU] Dept Pekerjaan Umum Direktorat Bina Marga. 1996. Tata Cara Perencanaan Teknik Lanskap Jalan No 33/TBM/1996 [Internet]. [diunduh 2014 Des 20]. Tersedia pada http://widyagama.ac.id/ajisuraji/wpcontent/ ㅂploads/2011/12/Pedoman-Teknik-No-033T-BM-1996-Tata-CaraPerencanaan-Teknik-Lansekap-Jalan.pdf

[Dirjen PU] Direktorat Jendral Penataan Ruang Dept. Pekerjaan Umum. 2008. Peraturan Menteri Pekerjaan Umum No. 5/PRT/M/2008 tentang Pedoman Penyediaan dan Pemanfaatan Ruang Terbuka Hijau di Kawasan Perkotaan [nternet]. [diunduh 2014 Des 20]. Tersedia pada http://id.scribd.com

[Distamkam] Dinas Pertamanan dan Pemakaman DKI Jakarta. 2001. Daftar Estilah. Jakarta (ID). Tidak dipublikasikan.

David FR. 2008. Manajemen Strategi. Jakarta (ID): Salemba Empat. Terjemahan Gari: Management: Concept and Cases.

Dewi K. 2011. Evaluasi tanaman tepi jalan di Kampus IPB Dramaga, Bogor [skripsi]. Bogor (ID): Institut Pertanian Bogor.

Harris CW, Dines NT. 1988. Time-Saver Standart for Landscape Architecture: Design and Construction Data. Second Ed. New York (US): McGraw-Hill Inc.

Hasim I. 2009. Tanaman Hias Indonesia. Depok (ID): Penebar Swadaya.

Hellmund PC, Smith DS. 2006. Designing Greenways: Sustainable Landscape for Nature and People. Washington (US): Island Press.

Hidayat IW. 2010. Kajian fungsi ekologi jalur hijau jalan sebagai penyangga lingkungan pada Tol Jagorawi. J Manusia dan Lingkungan. 17(2):124-133.

Joga N, Ismaun I. 2011. RTH 30\%! Resolusi (Kota) Hijau. Jakarta (ID): Gramedia.

Kencana I, Lestari G. 2008. Galeri Tanaman Hias Lanskap. Depok (ID): Penebar Swadaya.

Kinneat TC, Taylor JR. 1991. Marketing Research: An Applied Approach. New York (US): McGraw-Hill Inc.

[LPLБLab. Perencanaan Lanskap. 2005. Ruang Terbuka Hijau Wilayah Perkotaan. Departemen Arsitektur Lanskap, Fakultas Pertanian, Institut Pertanian Bogor. Tidak dipublikasikan.

[LVPG] Lehigh Valley Planning Commission. 2007. Open Space [Internet]. fdiunduh 2015 Mei 20]. https://lvpc.org/open-space 
Latief. 2013. Izin Hotel Baru di Bogor Terus Melonjak [Internet]. [diunduh 2014 Mei 20]. Tersedia pada http://m.kompas.com/properti/read/2013/03/26/ 12003850/Izin.Hotel.Baru.di

Larsson G. 2010. Land Management as Public Policy. Maryland (US): University Press of America, Inc.

Lusetyowati T. 2011. Analisa Penyediaan Ruang Terbuka Hijau Perkotaan, Studi Kasus Kota Martapura. Prosiding Seminar Nasional AVoER ke-3; 26-27 Oktober 2011; Palembang, Indonesia (ID): Fakultas Teknik Universitas Sriwijaya. Hlm 195-196. [diunduh 2014 Okt 25]. Tersedia pada: http://eprints.insri.ac.id/128/

Mirsa R. 2012. Elemen Tata Ruang Kota. Yogyakarta (ID): Graha Ilmu.

Napisah I. 2009. Evaluasi aspek fungsi dan kualitas estetika tanaman lanskap Kebun Raya Bogor: Kasus pohon dan perdu [skripsi]. Bogor (ID): Institut Pertanian Bogor.

Parker J, Bryan P. 1989. Landscape Management and Maintenance: A guide to it's Costing and Organization. Hants (UK): Gower Publishing Company.

Pramukanto Q, Hidayah AMA. 2011. Studi evaluasi taman kota sebagai taman terapuetik studi kasus: Taman Cilaki Atas, Kota Bandung. J Lansk Indones. 3(2):80.

Eurnomohadi N. 2008. RTH Miliki Tiga Fungsi Penting [Internet]. [diunduh 2014 Jan 14]. Tersedia pada http://www1.pu.go.id/uploads/berita/ppw020708 remi.htm

Rangkuti F. 1997. Analisis SWOT: Teknik Membedah Kasus Bisnis Cara Perhitungan Bobot, Rating dan OCAI. Jakarta (ID): Gramedia.

Ratnasari J. 2008. Galeri Tanaman Hias Daun. Depok (ID): Penebar Swadaya.

Rehman S, Younas G, Riaz A, Alamgir M, Ahmad Z. 2002. Impact of community involvement in urban plantation and landscape. Pakistan Journal of Applied Science. 2(6): 637-638.

Shodiq MA. 2013. Evaluasi pengelolaan ruang terbuka hijau Terminal Tawang Alin Jember [skripsi]. Bogor (ID): Institut Pertanian Bogor.

Simonds JO, Starke BW. 2006. Landscape Architecture: A Manual of Environmental Planning and Design. Fourth Ed. New York (US): McGrawHill Inc.

Sulistyantara B, Fatimah IS, Citra IH. 2005. Pengaruh taman lingkungan terhadap suhu udara di dalam taman dan di sekitarnya. J Lansk Indones. 1(1):7.

Yayat R. 2008. Studi daya dukung biofisik kawasan rekreasi Kebun Raya Bogor [skripsi]. Bogor (ID): Institut Pertanian Bogor.

Yogia LS. 2014. Kemampuan resapan air tanah pada berbagai penggunaan lahan di latosol Dramaga dan andosol Cisarua [skripsi]. Bogor (ID): Institut Pertanian Bogor. 


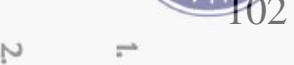

믐ำ

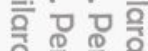

흥흐 음

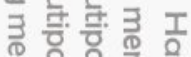

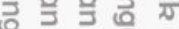

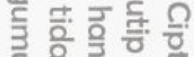

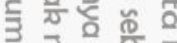

을

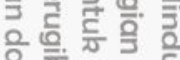

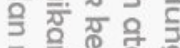

3 융

尔空苍

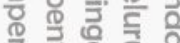

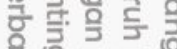

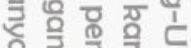

뚱응흥

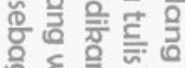

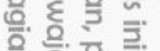

익

울 画产

을

들 율

즌 들

)

ट

돜 을

응 긍

일

잉

壳呫

율

음 흥 윰

ᄃ 웅

흉 응

品 
몽

일

을 을

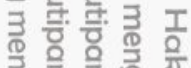

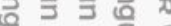

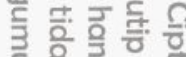

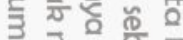

荝

은 들 웡

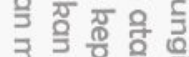

夏 즁 월

임열

흥 홍의 웅

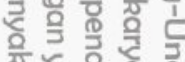

는 뜽을 흥

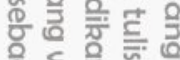

을 हूํํ으.

일

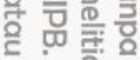

일

일 을

음 등

초 잉

든 응응

ㅋ. 혹

응 훅 훌

亟

孪 致 
들 믈

势

들를

일 일

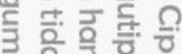

运运范

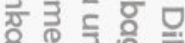

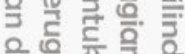

융

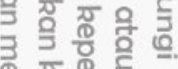

宩

잉

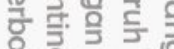

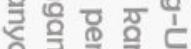

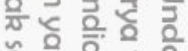

兽言 휼를

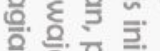

年

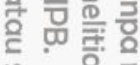

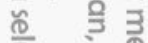

독 율

을 를

잉 严

ट

들 을을

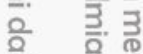

일

강

空呫

융 을 喜

음 흥 윰

ᄃ 웅

흥 항

촐. 를

鬲

紫

एण

高

을 은

总

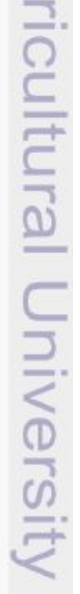


ำ

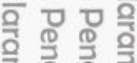

家 훙

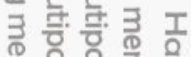

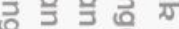

흥흘 둥 웅

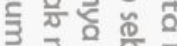

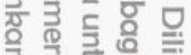

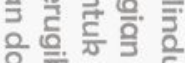

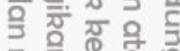

3 융

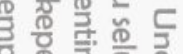

은 흥응

을 宁

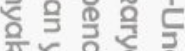

든흐응 흥

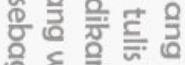

응. हू을

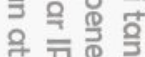

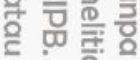

웅

들 율

즐 들

这 寒

ट

돌 들응

ㅋ.

응 훅 일

引

ర్థ

릉 站

융 을

음 흥 윰

政 
몸ำ

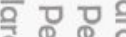

흐음

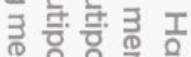

可高

둥흥ㄷㅎㅇ 웡

政范。

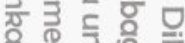

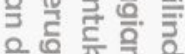

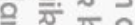

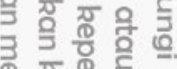

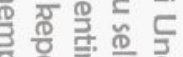

영

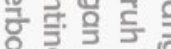

今응 뭉

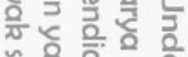

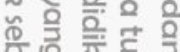

응해

을. 응 흥

을

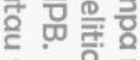

品 总

독 율

음 를

خ 일 券

ट

ㄴ. 늘을

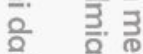

일

ర

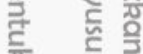

융 일

음 흥 뭉

章

항 훙

촐

प़̣

弯

ए

高

은 윽

家

色

흔 들

(1)

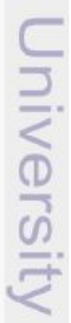


믈

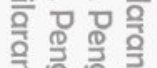

흘을 을

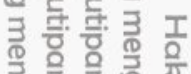

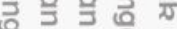

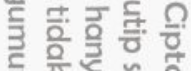

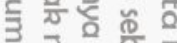

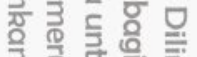

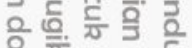

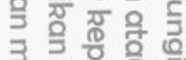

券

잉

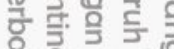

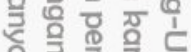

중 흔롱

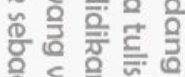

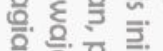

政

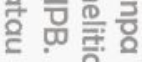

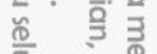

혁 율

ग 등

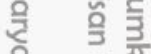

짐일

듴. 등을

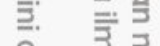

응 훅 혹

引

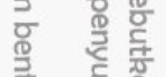

릉 站

(อ)

융 을

융 흥 훙

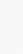


밈ำ

등ㅁํ을

흐음

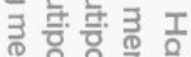

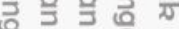

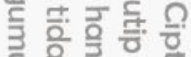

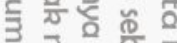

을

응들 동흘

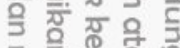

3 중

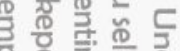

영

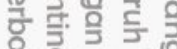

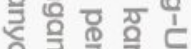

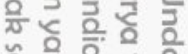

兽言 휼를

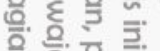

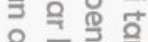

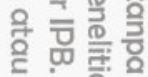

을

들 율

음 를

잉 귤

皮

독 들을

亞. 言要

응 흥 홀

引 웛

․ㅣㄹ

릉 站

융 을

응 흥육

일

흉 훙

홀

ㄸำ

弯

ए

ट

壱年

ถั

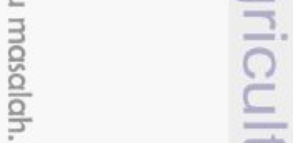

()

$\frac{5}{\frac{D}{5}}$ 
Lampiran 3 Kuesioner preferensi untuk pejalan kaki

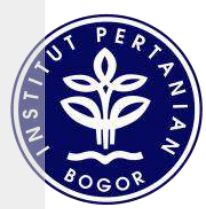

\section{Departemen Arsitektur Lanskap}

\section{Fakultas Pertanian}

Institut Pertanian Bogor

Nama Mahasiswa Judul Skripsi
: Putri Mariam Anindita Erline (A44100042)

: Pengelolaan Jalur Hijau Jalan di Kelurahan

Baranangsiang oleh Dinas Kebersihan dan Pertamaman, Kota Bogor

Kuesioner Pengguna Jalan di Jalur Hijau Jalan, Kelurahan Baranangsiang

ए人)

Bengan hormat,

Dalam rangka menyelesaikan tugas akhir sebagai mahasiswa program ștudi Arsitektur Lanskap, Departemen Arsitektur Lanskap, Fakultas Pertanian, Institut Pertanian Bogor, diperlukan dukungan Bapak/Ibu/Saudara/Saudari untuk mె̈ngisi kuesioner ini. Data yang terkumpul akan digunakan untuk tujuan åkademik. Kuesioner ini merupakan upaya untuk mengetahui keinginan dan Farapan masyarakat terhadap pengelolaan jalur hijau jalan di Kelurahan Baranangsiang, Kota Bogor. Data yang Anda berikan dijamin kerahasiaannya. Oleh sebab itu, saya berharap Anda mengisi kuesioner dengan subjektif tanpa ada paksaan dari pihak manapun. Terima kasih.

ए丁

Identitas Responden

玉. Nama

2. Alamat

3. Jenis kelamin

4. Usia

5. Pendidikan terakhir

6. Lokasi interview

Beri tanda silang $(\mathrm{X})$ yang menjadi pilihan Anda

1. Bagaimana aspek kebersihan jalur hijau jalan di Kelurahan Baranangsiang?

a. Sangat bersih

b. Bersih

c. Kurang bersih

d. Tidak bersih

2. Bagaimana aspek keamanan jalur hijau jalan di Kelurahan Baranangsiang?
a. Sangat aman
b. Aman
c. Kurang aman
d. Tidak aman

Bagaimana aspek kenyamanan jalur hijau jalan di Kelurahan Baranangsiang? a. Sangat nyaman 

b. Nyaman
c. Kurang nyaman
d. Tidak nyaman

4. Bagaimana aspek fasilitas (tempat sampah, halte, tempat duduk, lampu penerangan jalan, dll) yang ada di jalur hijau jalan Kelurahan Baranangsiang?
a. Sangat baik

b. Baik

c. Kurang baik

d. Tidak baik

5. Băgaimana aspek keindahan jalur hijau jalan di Kelurahan Baranangsiang? a.- Sangat indah

b. Indah

c. Kurang indah

d: Tidak indah

ळण

6. A 2a saran yang Anda berikan mengenai pengelolaan jalur hijau jalan di Kelurahan Baranangsiang? 
Lampiran 4 Kuesioner preferensi untuk pengguna kendaraan bermotor

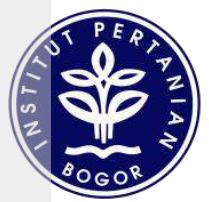

Departemen Arsitektur Lanskap

Fakultas Pertanian

Institut Pertanian Bogor

Nama Mahasiswa : Putri Mariam Anindita Erline (A44100042)

Judul Skripsi

: Pengelolaan Jalur Hijau Jalan di Kelurahan

Baranangsiang oleh Dinas Kebersihan dan Pertamaman,

Kota Bogor

Kuesioner Pengguna Jalan di Jalur Hijau Jalan, Kelurahan Baranangsiang

Bengan hormat,

Dalam rangka menyelesaikan tugas akhir sebagai mahasiswa program ștudi Arsitektur Lanskap, Departemen Arsitektur Lanskap, Fakultas Pertanian, Institut Pertanian Bogor, diperlukan dukungan Bapak/Ibu/Saudara/Saudari untuk mengisi kuesioner ini. Data yang terkumpul akan digunakan untuk tujuan akkademik. Kuesioner ini merupakan upaya untuk mengetahui keinginan dan harapan masyarakat terhadap pengelolaan jalur hijau jalan di Kelurahan Baranangsiang, Kota Bogor. Data yang Anda berikan dijamin kerahasiaannya. Oleh sebab itu, saya berharap Anda mengisi kuesioner dengan subjektif tanpa ada paksaan dari pihak manapun. Terima kasih.

ए

fdentitas Responden

1. Nama

2. Alamat

3. Jenis kelamin

4. Usia

5. Pendidikan terakhir

6. Lokasi interview

7. Jenis Kendaraan

\section{Beri tanda silang $(X)$ yang menjadi pilihan Anda}

1. Bagaimana aspek kebersihan jalur hijau jalan di Kelurahan Baranangsiang?

a. Sangat bersih

b. Bersih

c. Kurang bersih

d. Tidak bersih

2. Apakah keberadaan tanaman di jalur hijau (kiri atau kanan jalan) dan median jalan mengganggu jarak pandang Anda saat berkendara?

a. Sangat mempengaruhi

b. Mempengaruhi

c. Cukup mempengaruhi

d. Tidak mempengaruhi 
3. Bagaimana aspek fasilitas (papan petunjuk jalan, lampu penerangan jalan, halte dll) yang ada di jalur hijau jalan Kelurahan Baranangsiang?

a. Sangat baik

b. Bersih

c. Kurang baik

d. Tidak baik

4. Apakah Anda dapat melihat dengan jelas fasilitas (rambu lalu lintas, papan petunjuk jalan, lampu lalu lintas, dll) yang terdapat di jalur hijau?

a. Sangat jelas

$\mathrm{b}=\mathrm{I} J$ Jelas

c. $\bar{n}$ Kurang jelas

d:- Tidak jelas

5. Băgaimana aspek keindahan jalur hijau jalan di Kelurahan Baranangsiang?

$a_{=}^{\pi}$ Sangat indah

bơ Indah

c. Kurang indah

dis Tidak indah

6. Apa saran yang Anda berikan mengenai pengelolaan jalur hijau jalan di Keturahan Baranangsiang?

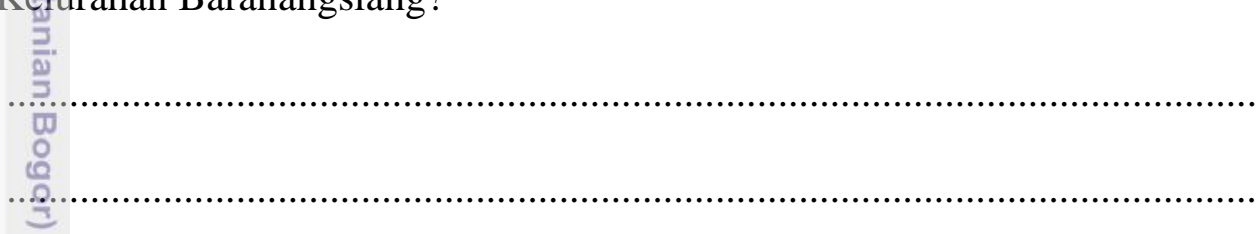




\section{RIWAYAT HIDUP}

Penulis dilahirkan di Jakarta pada tanggal 26 Juli 1992 dari pasangan Ayah Erwin Manan dan Ibu Nelliyarti. Pendidikan formal penulis diawali di TK 'Aisyiyah Bustanul Athfal 11 pada tahun 1996. Pendidikan formal dilanjutkan ke SD Negeri Mekarjaya XV pada tahun 1998, SMP Negeri 3, Depok, pada tahun 2004, dan SMA Negeri 97, Jakarta Selatan, pada tahun 2007. Tahun 2010 penulis lulus dari SMA Negeri 97 Jakarta dan pada tahun yang sama penulis lulus seleksi masuk Institut Pertanian Bogor melalui jalur USMI (Undangan Seleksi Masuk IPB) dan diterima di Departemen Arsitektur Lanskap, Fakultas Pertanian.

Penulis cukup aktif dalam mengikuti kegiatan akademis dan nonakademis. Selama mengikuti perkuliahan, penulis menjadi asisten Mata Kuliah Pendidikan Agama Islam pada Tahun Ajaran 2012/2013 dan Mata Kuliah Teknik Penulisan Ilmiah pada Tahun Ajaran 2013/2014. Penulis juga pernah aktif dalam berbagai organisasi intra kampus, yaitu Dewan Musholla Asrama A3 TPB IPB, Eatan Keluarga Muslim TPB Angkatan 47, Dewan Perwakilan Mahasiswa Fakultas Pertanian, Paguyuban Bidik Misi, dan Himpunan Mahasiswa Arsitektur Eanskap (HIMASKAP). Penulis juga cukup aktif di beberapa organisasi ekstra k̇ampus, yaitu Kesatuan Aksi Mahasiswa Muslim Indonesia (KAMMI) IPB, KAMMI Daerah Bogor, dan Ikatan Muslim Alumni 3 Depok.

Penulis pernah menjadi trainer dalam kegiatan Tutor Desain GrafisSPECTRUM RAP yang diselenggarakan LDK Al-Hurriyyah pada tahun 2012. Benulis cukup aktif dalam mengikuti lomba. Beberapa prestasi yang diraih antara Bain Juara II Lomba Karikatur "Celebration Day" Asrama Putri TPB IPB tahun 2010, Juara II Lomba Karikatur "Ekologi” dalam Forsia Islamic Festival IPB tăhun 2011, Juara II Lomba Essai dalam Forsia Islamic Festival tahun 2012, dan mendapat pendanaan pada Program Kreativitas Mahasiswa bidang Karsa Cipta tahun 2012. 